\title{
Site-specific adaptation by natural selection. A case study with lentil.
}

\author{
Michael Ruland
}

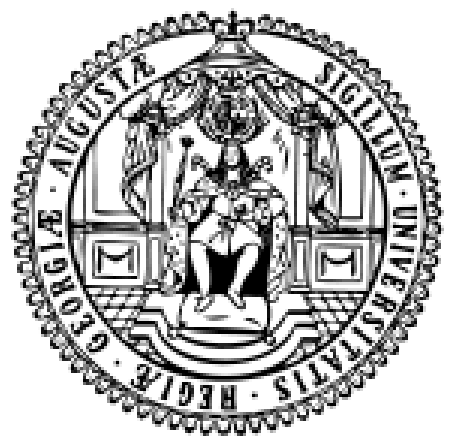




\title{
Site-specific adaptation by natural selection.
}

\section{A case study with lentil.}

\author{
Dissertation \\ to obtain the Ph. D. degree \\ in the International Ph. D. Program for Agricultural Sciences in Göttingen (IPAG) \\ at the Faculty of Agricultural Sciences \\ Georg-August-Universität Göttingen, Germany

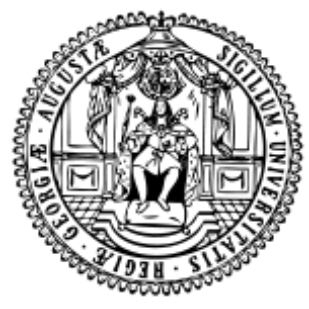 \\ presented by \\ Michael Ruland \\ born in Filderstadt, Germany
}




\section{7}

Supervisor: $\quad$ Prof. Dr. Heiko C. Becker

Co-supervisor: $\quad$ Prof. Dr. Gunter Backes

Date of dissertation: 13 July 2017 


\section{TABLE OF CONTENTS}

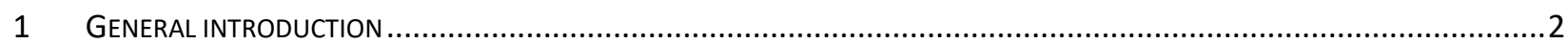

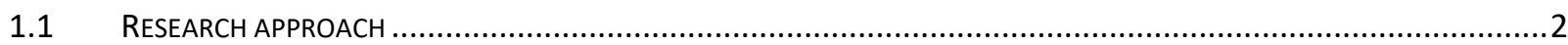

1.2 BIOLOGICAL CHARACTERISTICS, DOMESTICATION AND CULTIVATION OF LENTIL............................................

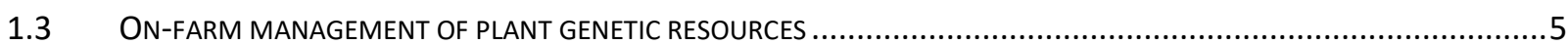

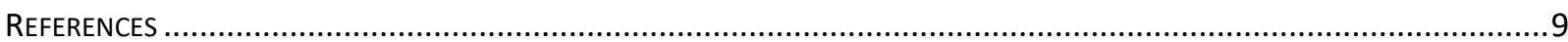

2 PERFORMANCE OF POPULATIONS UNDER SITE-SPECIFIC NATURAL SELECTION ...................................................

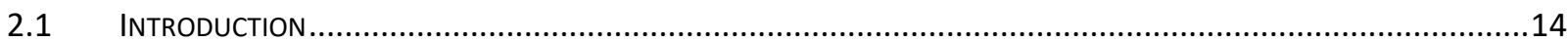

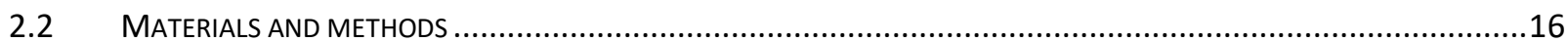

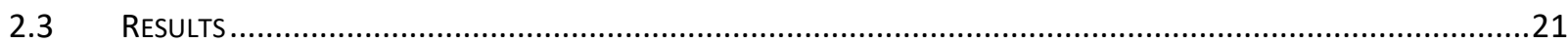

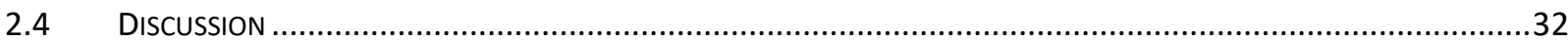

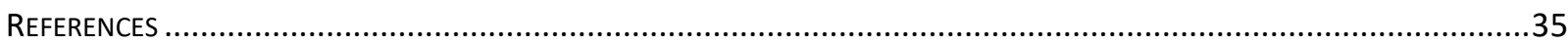

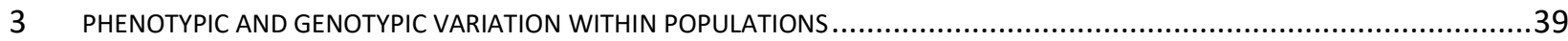

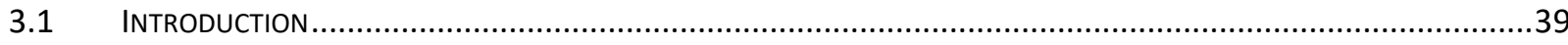

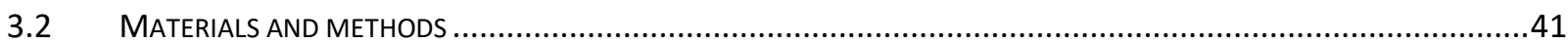

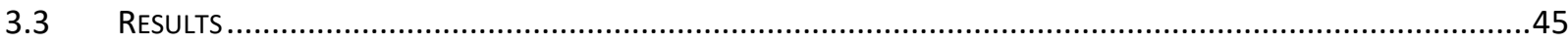

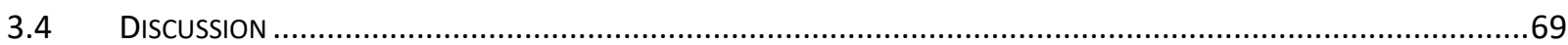

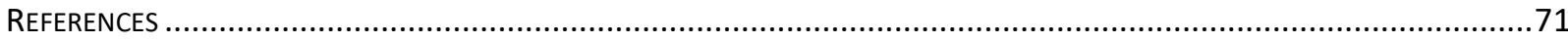

4 PERFORMANCE AND WITHIN-POPULATION VARIATION OF SELECTIONS FOR EXTREME SEED SIZE ...................................73

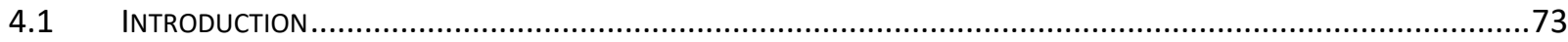

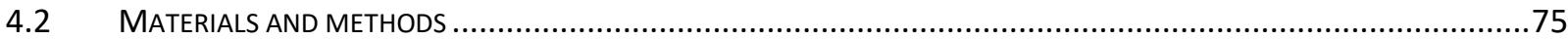

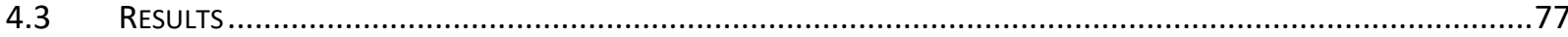

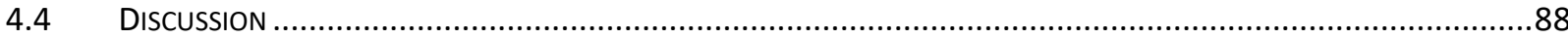

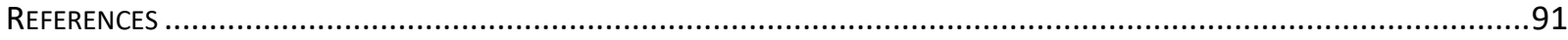

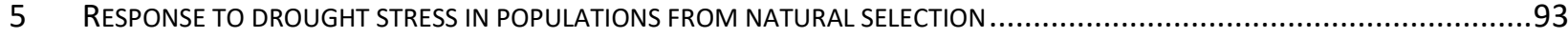

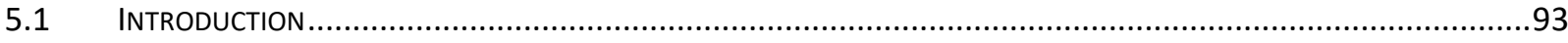

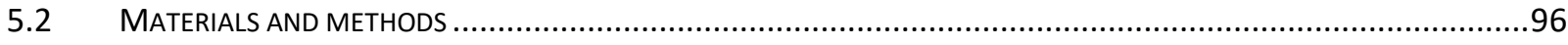

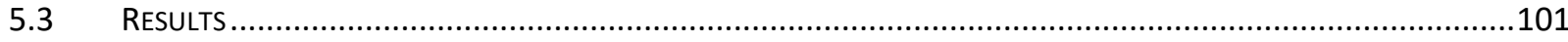

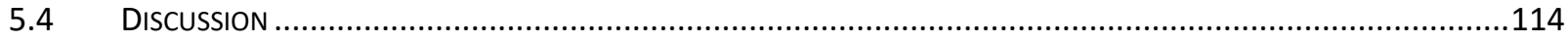

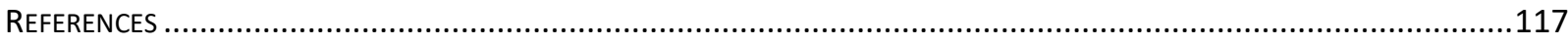

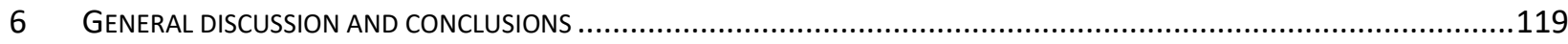

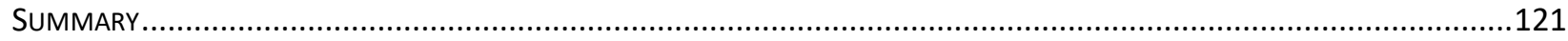

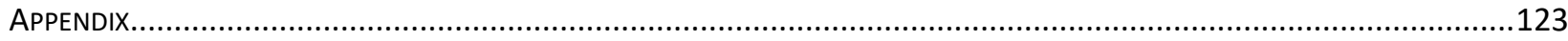

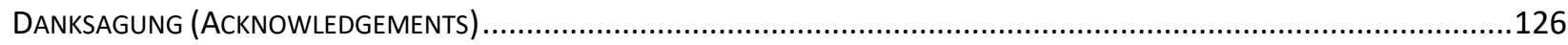

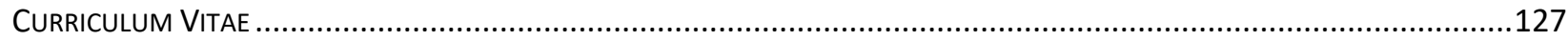




\section{General introduction}

\subsection{RESEARCH APPROACH}

\section{PREVIOUS WORK}

Preliminary work leading to the set-up of this project began in 1996 with the selection of three distinct old lentil cultivars (landraces), the multiplication of these cultivars in Göttingen and subsequent cultivation at three diverse farms during 1997-2001 to study site-specific adaptation in an on-farm management by natural and conscious selection (Horneburg and Becker 1998; Horneburg 2003b; Horneburg and Becker 2008). Additionally, the outcrossing rate of the three cultivars depending on environmental conditions of the year and the location was studied (Horneburg 2006). During 2006-2010, cultivation under natural selection continued for five more years at the same three farms. Moreover, selection on extreme seed sizes was done in 2000 and repeated after regeneration at one location for six generations.

For the current project, the initial material, an intermediate generation after five years of site-specific natural selection, populations after ten generations of natural selection, and selections for large and small seeds from each of the three cultivars are available (FIGURE 1.1).

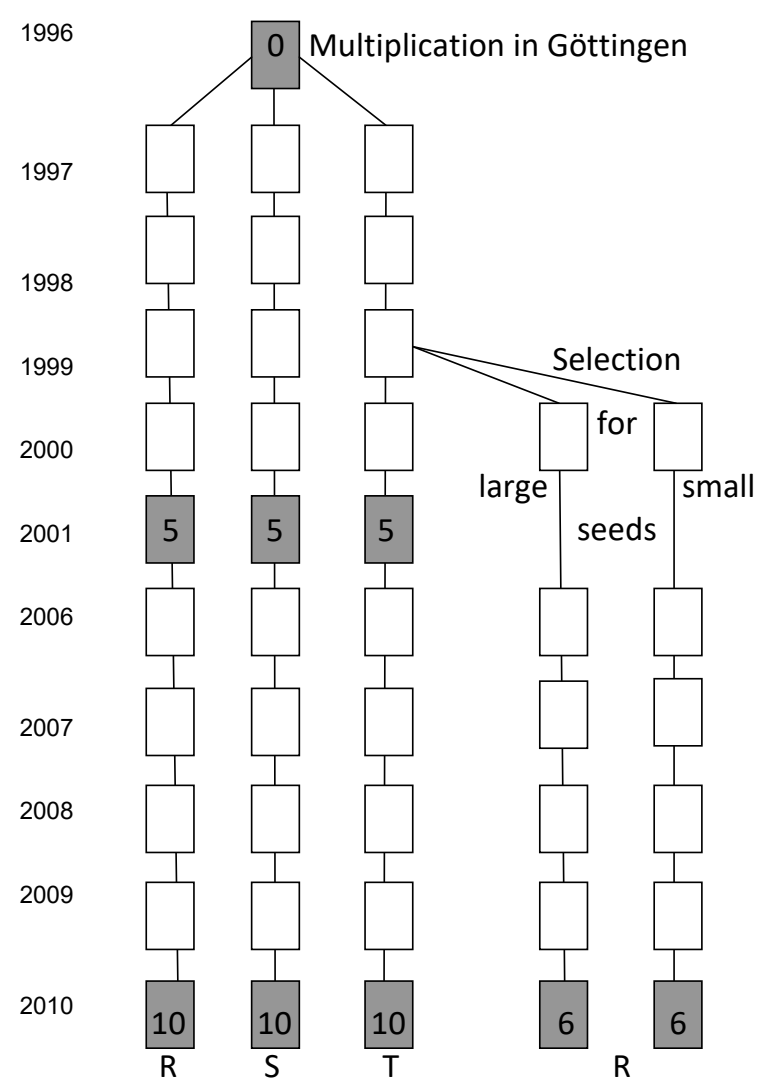

FIGURE 1.1 Natural selection on farm at Reinshof (R), Schönhagen (S), and Tangsehl (T) and calibration for large and small seeds at Reinshof in three cultivars. The initial material (0), and material in generation 5, 6, and 10 is the source for this study. 


\section{AIM OF THE STUDY}

The following four main questions are subject of this research and will be examined and discussed by the experiments described in the following four chapters (CHAPTER 2, 3, 4,5) and finally will be addressed in the closing chapter of the general discussion and conclusions (CHAPTER 6):

1. Did natural selection lead to site-specific adaptation? (CHAPTER 2)

a) How does the phenotypic performance differ between populations selected at three farms?

b) What is the effect of selection when comparing generation zero (the initial population), five, and ten in terms of phenotypic performance and site-specific adaptation?

2. Did natural selection alter phenotypic and genotypic variability? (CHAPTER 3)

a) Did natural selection affect phenotypic diversity differently depending on the site of selection?

b) Did natural selection alter genotypic diversity?

3. What is the importance of seed weight for site-specific adaptation? (CHAPTER 4)

a) How do specific selections for extreme seed size (large versus small seeds) influence yield and other traits compared to the initial population and populations under natural selection?

b) Did the selection for extreme seed size alter genotypic diversity?

4. Was drought stress a significant factor for site-specific population development? (CHAPTER 5) Did site-specific natural selection lead to increased drought tolerance? 


\subsection{BIOLOGICAL CHARACTERISTICS, DOMESTICATION AND CULTIVATION OF LENTIL}

Lentil (Lens culinaris Medikus) belongs to the botanical family of Fabaceae, the genus Lens Miller, and the tribe Fabeae (syn. Vicieae). Beside the species L. culinaris, the Lens-genus comprises three more sympatric diploid $(2 n=2 x=14$ ) species: L. lamottei, which was classified to the secondary gene pool, L. ervoides, and L. nigricans, which form the most distant (tertiary) gene pool (Wong et al. 2015). After numerous changes in the taxonomy within the Lens-genus, there are three subspecies within the species L. culinaris: ssp. orientalis, the putative wild progenitor of ssp. culinaris (Ladizinsky 1993; Sarker and Erskine 2006) and ssp. odemensis, which form the primary gene pool for L. culinaris ssp. culinaris, the cultivated lentil. According to Wong et al. (2015), from classification and characterization within the genus Lens using genotyping-bysequencing, L. nigricans was observed most distant from the cultivated lentil in a 'quaternary' group, and ssp. odemensis was observed to be a sister clade to L. lamottei and thus suggested to be classified to the secondary gene pool. The Lentil Genome v1.2 is available in a pre-release form and its predicted haploid genome size is $4032 \mathrm{Mb}$ (Lentil Genome Pre-Release; Foyer et al. 2016; Munoz et al. 2017).

Lentil is an annual south-east-Mediterranean cool-season food legume crop. It shares the history of domestication with the ancient cereals einkorn and emmer as well as with barley and peas originating from the Fertile Crescent of the Near East, where it has been domesticated more than 2000 years BC (Reda 2015; Harlan 1992). Oldest archeological remains of lentils where found in Greece and Syria which were dated back from 7,500 to 11,000 BC (Sonnante et al. 2009).

Lentil is autogamous with a variable degree of outcrossing, as observed by Horneburg (2006) using the dominant 'orange cotyledons' as a marker, with the range of $0.06 \%$ to $5.12 \%$ depending on cultivar, year, and location. Outcrossing rates for Turkish and Greek landraces and Chilean populations were calculated with $2.2 \%, 2.9 \%$, and $6.6 \%$, respectively, from the segregation of progenies from heterozygote plants for co-dominant isozyme loci (Erskine and Muehlbauer 1991).

The economic importance of lentil cultivation in Central Europe decreased during the last century, although it was grown traditionally on marginal agricultural land mainly for self-supply until the 1950s (Horneburg 2003a). Small to medium scale production of lentil in Europe can still be found in the Mediterranean regions of France, Spain, Italy and Greece (Piergiovanni 2000; FAOSTAT 2014). At the global scale, total production increased during the last years and reached 4.8 million metric tons in 2014 (FAOSTAT 2014). Main production worldwide takes place in Canada with nearly two million tons followed by India and Turkey with 1.1 and 0.3 million tons, respectively (FAOSTAT 2014).

Lentil production in Germany did not vanish due to reduced consumption, rather due to its unstable yield and limited outlet marked and thus became less attractive for modern farming. Due to rainy summers, lentils in Central or Northern Europe are grown in intercropping systems with cereals to obtain satisfying seed quality, which may not be attractive for large-scale, industrialized growing systems, but is certainly applied in organic farming, where the product often is locally commercialized (Wang et al. 2012; Gruber et al. 2011). A new approach for a pure leguminous intercropping system with pea and lentil is currently under investigation for its practicability (University of Hohenheim 2016).

Lentil is generally adapted to warm and relatively dry climates. It can be grown in dryer areas than other pulse crops like faba bean or chickpea, with an annual rainfall as little as $250 \mathrm{~mm}$ (Materne and Siddique 2009). Materne and Siddique (2009) summarized three major climatic regions of the world, where lentil is 
grown: (1) West Asia, North Africa, Australia, and the Mediterranean, where it is grown as a winter crop, growing slowly after sowing and as temperatures rise in spring to early summer, the crop rapidly develops and ripens before temperatures are too high; (2) the sub-tropical regions of India and neighboring countries, where it is sown in winter after the monsoon rains, but temperatures are higher; and ( 3 ) at high altitude and/or latitude (central Turkey, USA, Europe, Canada), where it is sown in spring on stored moisture from snow melt or rainfalls in winter or early spring and grows when temperatures are warm and days are long.

Historically, traditional growing areas for lentil in Germany were on dry, limestone residual marginal soils as found in the low mountain range of central and southern Germany (Becker-Dillingen 1929). In the Swabian Alb, one of these typical regions in the south-west of Germany, an old landrace (Späths Alblinse) underwent its revival in 2001, when an association of organic farmers developed a production system with a centralized cleaning, packing, and marketing unit, and in this way became the most significant lentil producers until today in Germany (John 2015).

\subsection{ON-FARM MANAGEMENT OF PLANT GENETIC RESOURCES}

Plant genetic resources (PGR) are defined as the entire genetic material available in a species for plant breeding (Becker 2011). Three genepools are usually distinguished in this context. The primary genepool is defined as the species itself and closely related subspecies under the precondition of sexual compatibility to perform crossings without specific biotechnological methods. The secondary genepool includes genetically more distant species or subspecies, where gene transfer by conventional crossing is difficult and is challenged by weak performance of the offspring, low fertility, and/or low seed set. Species that can be used in plant breeding only with the help of technical procedures, e.g. embryo rescue and tissue culture, form the tertiary genepool of a crop species.

Within the primary genepool, exotic material, such as wild relatives, exotic breeding material, e.g. breeding lines from different countries and climate zones, and adapted breeding material can be differentiated. The adapted material is the most frequently used source for the development of new cultivars by breeders and include modern breeding lines and old obsolete cultivars, often referred to as 'landraces'. Zeven (1998) reviewed various definitions for 'landrace' and suggested the following: "an autochthonous landrace is a variety with a high capacity to tolerate biotic and abiotic stress, resulting in a high yield stability and an intermediate yield level under a low input agricultural system". Another more precise definition is given with "a landrace is a dynamic population(s) of a cultivated plant that has historical origin, distinct identity and lacks formal crop improvement, as well as often being genetically diverse, locally adapted and associated with traditional farming systems" by Camacho Villa et al. (2005). Taking the suggestions and discussions of multiple authors into account, including the aforementioned, the following definition was suggested at the second meeting of the On-farm Conservation and Management Taskforce of the European Cooperative Group on Genetic Resources (http://www.ecpgr.cgiar.org/workinggroups/on-farm-conservation/): "A landrace of a seed-propagated crop is a variable population, which is identifiable and usually has a local name. It lacks 'formal' crop improvement, is characterized by a specific adaption to the environmental conditions of the area of cultivation (tolerant to the biotic and abiotic stresses of that area) and is closely associated with the uses, knowledge, habits, dialects, and celebrations of the people who developed and continue to grow it." (cited in Veteläinen et al. 2009). 
With the development of scientific plant breeding and the industrialization of agriculture, modern cultivars were developed and released by public or private institutions or companies and professional growers do rarely maintain their own genetic resources and varieties anymore. The 'modern high yielding' cultivars were distributed and planted covering a large area and consequently triggered the discussion on genetic diversity in agriculture (Schnell 1980; Becker 2000). Since then, concepts for safeguarding PGR are widely discussed (Berthaud 1997). A special interest for locally adapted, 'traditional' varieties (landrace, farmrace, German: Landsorte, Hofsorte) can be found in the organic community, where these varieties or populations are often maintained and used as 'open-access' genetic resources that can be further improved on-farm by breeding as 'true-to-seed' varieties. In organic agriculture, low-input farming, and small scale (self-sufficient) farming or horticulture diversity is appreciated and often trumps properties of modern commercial (hybrid, sterile) cultivars, e.g. uniformity and higher yields.

\section{POPULATION DEVELOPMENT AND SITE-SPECIFIC ADAPTATION}

In situ ('dynamic') maintenance of PGR allows for evolutionary adaptation to site-specific conditions, as the material is constantly kept under cultivation, in contrast to ex situ ('static') conservation, e.g. in gene banks, with infrequent multiplication of the accessions during long-term storage. There are different approaches for such a dynamic conservation of PGR (Bretting and Duvick 1997; Hammer 2004; Goldringer et al. 2001a).

On-farm conservation refers to in situ conservation of PGR by using them in current agricultural production systems and in this way enables evolutionary development and adaptation to the environment and contributes to the improvement of agro-biodiversity and cultural diversity, the availability of old obsolete cultivars, landraces, or neglected species, and the maintenance of traditional knowledge (Becker et al. 2002). One of the latest definitions of on-farm conservation was formulated by Veteläinen et al. (2009) as 'the management of genetic diversity of locally developed crop varieties (landraces) by farmers within their own agricultural, horticultural or agri-silvicultural systems'. Combining the maintenance of PGR onfarm and the use of evolutionary, site-specific adaptation effects, one could think about including multiple farms covering a large range of environmental conditions. In the sum of all farms, genetic diversity may not be only maintained, but the material may also be improved by adaptation or even further diversified compared to the initial material (Jana and Khangura 1986; Horneburg and Becker 2008).

Studies on site-specific adaptation by natural selection are available using a similar approach with a different kind of material. Composite cross populations (CCP, German: Evolutionsramsche) from a complex crossing scheme were generated to combine diverse parental components, which could be landraces, breeding lines, cultivars, or a mixture of all, to a population of segregating, heterozygous, and heterogeneous individuals. Such a population is then given to diverse farms to develop locally adapted 'modern landraces' (or farm-races) by 'evolutionary plant breeding'. This approach was suggested by Suneson (1956) working with barley populations and continued by Allard et al. (1972). From these studies Allard (1990) concluded that evolutionary processes can be effective to increase the frequency of genotypes with multiple resistance loci against pathogens in a variable population. The concept was further adopted in the area of organic plant breeding research and dynamic management of wheat populations (Goldringer et al. 1998; Goldringer et al. 2001a; Goldringer et al. 2001b), studying genetic drift and selection (Enjalbert et al. 1999), the evolution of resistances (Paillard et al. 2000), and the genetic differentiation in response to different climatic conditions (Goldringer et al. 2006; Rhone et al. 2008). From 
the studies in a barley composite cross population in England, Ibrahim and Barrett (2001) describe significant variation and evolutionary changes and suggest the creation of CCPs from various landraces as "dynamic reservoirs of genetic variation" and a good basis for the establishment of national breeding programs e.g. in developing countries. For low input systems and organic agriculture in Europe, evolutionary plant breeding from composite cross wheat populations was studied in England (Phillips and Wolfe 2005; Wolfe et al. 2006; Wolfe et al. 2008) and in Germany by Finckh (2007), Finckh et al. (2009), (Brumlop and Finckh 2013), and (Weedon et al. 2015). They found a positive development in yield and grain quality, diversity in resistances to brown rust, and a good frost survival ability.

\section{GENETIC DIVERSITY: THE PREREQUISITE FOR DEVELOPMENT}

Genetic diversity is the basis for the development of new cultivars adapted to changing environmental conditions and changing requirements in crop production, in the food industry, and for the consumers. Thus, maintenance of various PGR and their inherent genetic diversity are an essential resource for longterm food security.

Autogamous species are restricted in their intra-population genetic diversity and are, on the one hand, prone to become genetically impoverished by selection and/or gene drift. On the other hand, if selection is positive, it is more efficient and faster compared to selection in allogamous species. Despite the relatively low outcrossing rate in lentil, highly adapted genetic material is present in various regions and was collected and used for research and breeding programs at the International Center for Agricultural Research in Dry Areas (ICARDA) in Syria (Erskine et al. 1989; Erskine 1997). Research in lentil advanced profoundly with the work of William Erskine, formerly working as a lentil breeder, leader of the Germplasm Improvement Program, and Assistant Director General (Research) at the ICARDA, and currently holding the position of the director of the Centre for Plant Genetics and Breeding at the University of Western Australia, contributing numerous publications on genotypic variation in PGR of lentil from the 1980s until today (Erskine 1983; Erskine et al. 1985; Erskine et al. 1989; Erskine and Muehlbauer 1991; Erskine 1997; Erskine et al. 1998; Erskine et al. 2011a; Sarker et al. 2005; Erskine et al. 2011a; Erskine et al. 2011b).

In the past, landraces of lentil supported farmers in some harsh climatic regions, e.g. in Morocco, Ethiopia, or Bangladesh, therefore the understanding of "the adaptation [...] is basic to its effective improvement by breeding" and many released cultivars were selected directly from landraces in the ICARDA germplasm collection (Erskine 1997). Obviously, genetic diversity varies strongly depending on the origin and type of the material and its respective intensity of cultivation and selection by farmers and/or breeders. Very high levels of genetic diversity in landraces from Mediterranean regions of Greece and Turkey and three major genetically different groups based on their geographical origin among commercial cultivars from Australia, Canada, USA, and breeding lines from the ICARDA were identified (Lombardi et al. 2014). Genetic diversity and resources of lentil can still be found on farms, e.g. in central Italy, where Negri (2003) documented 33 lentil landraces, most of them still of economic importance for the farmers and sold in the neighboring town or in the wider markets.

\section{IMPORTANCE OF SEED SIZE FOR NATURAL SELECTION}

General biological considerations on the effect of natural selection on seed weight and seed size would suggest a reduction in the long term, as it could be of advantage for the plants reproduction, especially under stress, to develop smaller and lighter seeds most efficiently. The number of seeds may stay the same 
or increase under favorable conditions for such populations under long-term natural selection. On the other hand, large seeds may ensure the survival and regeneration of species, as more resources of a larger embryo imply faster seedling development, better competitive ability and better access to resources (Sadras 2007). In ecology, seed size effects are widely discussed in terms of adaptation by stabilizing selection and the size-versus-number trade-off (Silvertown 1989; Haig 1989; Sadras 2007). For populations of wild plant species, Silvertown (1989) claims, due to low heritability and large plasticity (genotype $x$ environment interaction) found for many species, "constancy of mean seed size may be due to developmental canalization to a size set by previous selection rather than a continuing process of stabilizing selection". Whereas Haig (1989) dissents in his letter to the aforementioned article and argues that "characters closely related to fitness are expected to have low heritabilities because of the rapid elimination of maladaptive variation" and thus, "the absence of significant genetic variation in wild populations is strong evidence for the continuing action of natural selection". However, both scientists state a different situation observed for crop plants, where "plants (are) grown under controlled conditions where phenotypic plasticity is limited" (Silvertown 1989) and "high heritabilities in some crop species prove that genetic variation for seed size is possible" (Haig 1989).

Studies in lentil have shown effects of seed size e.g. on water uptake, germination, and seedling growth (Al-Karaki 1998; Hojjat 2011), yield and yield components (Bicer 2009), and adaptation to temperature and rainfall (Erskine 1996). Erskine et al. (1985) studied 24 genotypes ranging in seed weight from 26.1 to 69.4 $\mathrm{mg}$ and calculated a broadsense heritability for seed weight of $h^{2}=0.98$ and found positive genetic correlations of seed weight with seed yield (0.468) and cooking time (0.919) and a negative correlation with protein content $(-0.621)$. Because seed size parameters are important parameters for the end uses and the processing industry, Fedoruk et al. (2013) and Fedoruk (2013) studied the heritability of seed size parameters, which was relatively high $0.92,0.94$, and 0.60 for seed diameter, plumpness and thickness, respectively, and mapped quantitative trait loci (QTL) for these traits to be used in lentil breeding.

\section{ADAPTATION TO DROUGHT STRESS CONDITIONS BY NATURAL SELECTION}

On-farm management of plant genetic resources allows for local adaptation e.g. to pedoclimatic conditions by making use of genotype by environment interaction during conscious and/or natural selection (Simmonds 1991; Horneburg and Becker 2008). Genetic adaptation may have various causes, e.g. differences in the tolerance to biotic and/or abiotic stresses, which may differ between the selection sites. Temporal limitations in water availability can occur due to a low water holding capacity of the soil e.g. on sandy soils. Drought stress on lentil has different severity on biomass and grain yield depending on the growth stage, causing reduced vegetative growth and limiting ramification in early stages and significant grain yield reduction when occurring during flowering, grain filling, or maturity (Idrissi et al. 2015). Given a certain initial diversity, drought tolerance may be improved for populations developed by natural selection under conditions with frequent water scarcity. In this way, in the long term, on-farm management of plant genetic resources may be a 'pre-breeding' approach for crop adaptation to changing climatic conditions. Studying rice varieties under static and dynamic management, Tin et al. (2001) observed later flowering and maturity for those under dynamic conservation and reduced drought stress tolerance compared to ex situ populations due to lower drought stress pressure in the modern agronomic management compared to the conditions when these varieties were developed. 


\section{REFERENCES}

Al-Karaki GN (1998) Seed Size and Water Potential Effects on Water Uptake, Germination and Growth of Lentil. Journal of Agronomy and Crop Science 181:237-242. doi:10.1111/j.1439-037X.1998.tb00423.x.

Allard RW (1990) The Genetics of Host-Pathogen Coevolution: Implications for Genetic Resource Conservation. Journal of Heredity 81:1-6.

Allard RW, Kahler AL, Weir BS (1972) The effect of selection on esterase allozymes in a barley population. Genetics 72:489-503.

Becker HC (2000) Einfluss der Pflanzenzüchtung auf die genetische Vielfalt. Schriftenr. Vegetationskunde 32:87-94.

Becker HC (2011) Pflanzenzüchtung, 2nd edn. Eugen Ulmer KG, Stuttgart (Hohenheim).

Becker HC, Bergmann H, Jantsch P, Marggraf R (2002) Darstellung und Analyse von Konzepten des Onfarm-Managements pflanzengenetischer Ressourcen unter besonderer Berücksichtigung der ökonomischen Rahmenbedingungen in Deutschland. Studie für das Bundesministerium für Verbraucherschutz, Ernährung und Landwirtschaft. No. 317-7723-2/1, Göttingen.

Becker-Dillingen J (1929) Handbuch des Hülsenfruchtanbaues und Futterbaues, Vol 3. Paul Parey, Berlin.

Berthaud J (1997) Strategies for conservation of genetic resources in relation with their utilization. Euphytica 96:1-12.

Bicer BT (2009) The effect of seed size on yield and yield components of chickpea and lentil. African Journal of Biotechnology 8:1482-1487.

Bretting PK, Duvick DN (1997) Dynamic Conservation of Plant Genetic Resources. Adv Agron 61:1-51. doi:10.1016/S0065-2113(08)60661-6.

Brumlop S, Finckh MR (2013) Auswinterung im Jahr 2011/12: Auswirkungen auf WinterweizenLiniensorten und Winterweizenpopulationen in der F10. 12. Wissenschaftstagung Ökologischer Landbau:192-195.

Camacho Villa TC, Maxted N, Scholten M, Ford-Lloyd B (2005) Defining and identifying crop landraces. Plant Genetic Resources 3:373-384. doi:10.1079/PGR200591.

Enjalbert J, Goldringer I, Paillard S, Brabant P (1999) Molecular markers to study genetic drift and selection in wheat populations. Journal of Experimental Botany 50:283-290. doi:10.1093/jexbot/50.332.283.

Erskine W (1983) Relationship between the yield of seed and straw in lentil. Field Crops Research 7:115121. doi:10.1016/0378-4290(83)90016-3.

Erskine W (1996) Seed-size effects on lentil ( Lens culinaris) yield potential and adaptation to temperature and rainfall in West Asia. The Journal of Agricultural Science 126:335-341. doi:10.1017/S002185960007489X.

Erskine W (1997) Lessons for breeders from land races of lentil. Euphytica 93:107-112. doi:10.1023/A:1002939704321.

Erskine W, Adham Y., Holly L. (1989) Geographic distribution of variation in quantitative traits in a world lentil collection. Euphytica 43:97-103. 
Erskine W, Chandra S, Chaudhry M, Malik IA, Sarker A, Sharma B, Tufail M, Tyagi MC (1998) A bottleneck in lentil: widening its genetic base in South Asia. Euphytica 101:207-2011.

Erskine W, Muehlbauer FJ (1991) Allozyme and morphological variability, outcrossing rate and core collection formation in lentil germplasm. Theoretical and Applied Genetics 83:119-125. doi:10.1007/BF00229234.

Erskine W, Sarker A, Kumar S (2011a) Crops that feed the world 3. Investing in lentil improvement toward a food secure world. Food Security 3:127-139. doi:10.1007/s12571-011-0124-5.

Erskine W, SARKER A, Ashraf M (2011b) Reconstructing an ancient bottleneck of the movement of the lentil (Lens culinaris ssp. culinaris) into South Asia. Genetic Resources and Crop Evolution 58:373-381. doi:10.1007/s10722-010-9582-4.

Erskine W, Williams PC, Nakkoul H (1985) Genetic and environmental variation in the seed size, protein, yield, and cooking quality of lentils. Field Crops Research 12:153-161. doi:10.1016/03784290(85)90061-9.

FAOSTAT (2014), http://www.fao.org/faostat/en/\#search/lentil (accessed on 19 April 2017).

Fedoruk MJ (2013) Linkage and association mapping of seed size and shape in lentil. M. Sc. Thesis, Saskatoon, Saskatchewan.

Fedoruk MJ, Vandenberg A, Bett KE (2013) Quantitative Trait Loci Analysis of Seed Quality Characteristics in Lentil using Single Nucleotide Polymorphism Markers. The Plant Genome 6:0. doi:10.3835/plantgenome2013.05.0012.

Finckh MR (2007) Conservation and generation of genetic resources through development of modern landraces of field crops. Why we need co-evolution in the field. 9. Wissenschaftstagung Ökologischer Landbau.

Finckh MR, Steffan P, Brumlop S, Goldringer I (2009) Diversität in der F5 von dynamisch evolvierten Weizen Composite Cross Populationen. 10. Wissenschaftstagung Ökologischer Landbau:256-258.

Foyer CH, Lam HM, Nguyen HT, Siddique KH, Varshney RK, Colmer TD, ..., Cooper JW (2016) Neglecting legumes has compromised human health and sustainable food production. Nature Plants:16112.

Goldringer I, Enjalbert J, David J, Paillard S, Pham JL, Brabant P (2001a) Dynamic management of genetic resources: a 13-year experiment on wheat. In: Cooper HD, Spillane C, Hodgkin T (eds), Broadening the genetic base of crop production. CABI, London, pp 245-260.

Goldringer I, Enjalbert J, Raquin A, Brabant P (2001b) Strong selection in wheat populations during ten generations of dynamic management. Genet. Sel. Evol. 0:1-23.

Goldringer I, Paillard S, Enjalbert J, David JL, Brabant P (1998) Divergent evolution of wheat populations conducted under recurrent selection and dynamic management. Agronomie 18:413-425. doi:10.1051/agro:19980506.

Goldringer I, Prouin C, Rousset M, Galic N, Bonnin I (2006) Rapid differentiation of experimental populations of wheat for heading time in response to local climatic conditions. Annals of botany 98:805-817. doi:10.1093/aob/mcl160.

Gruber S, Wang L, Zikeli S, Mammel W, Claupein W (2011) Entwicklung von Anbausystemen für Linsen im ökologischen Landbau. 11. Wissenschaftstagung Ökologischer Landbau:278-281. 
Haig D (1989) Seed size and adaptation. Trends in Ecology \& Evolution 4:145. doi:10.1016/01695347(89)90214-0.

Hammer K (2004) Resolving the challenge posed by agrobiodiversity and plant genetic resources - an attempt, Beiheft Nr. 76 zu Journal of Agriculture and Rural Development in the Tropics and Subtropics. Kassel University Press, Kassel.

Harlan JR (1992) Crops and Man, 2nd edn., Madison, Wisconsin, USA.

Hojjat SS (2011) Effect of seed size on germination and seedling growth of some Lentil genotypes (Lens culinaris Medik.). International Journal of Agriculture and Crop Science 3:1-5.

Horneburg B (2003a) Frischer Wind für eine alte Kulturpflanze! Linsen im ökologischen Anbau, ihre Geschichte und Verwendung, Göttingen.

Horneburg B (2003b) Standortspezifische Sortenentwicklung: Eine Studie mit Landsorten der Linse. Schriften zu Genetischen Ressourcen. Band 21.

Horneburg B (2006) Outcrossing in lentil (Lens culinaris) depends on cultivar, location and year, and varies within cultivars. Plant Breeding 125:638-640.

Horneburg B, Becker HC (1998) Landsorten der Linse - Von der Genbank über den Acker in den Magen. In: Begemann F (ed), Schriften zu Genetischen Ressourcen. ZADI, Bonn, pp 235-238.

Horneburg B, Becker HC (2008) Crop Adaptation in On-Farm Management by Natural and Conscious Selection. A Case Study with Lentil. Crop Science 48:203-212.

Ibrahim KM, Barrett JA (2001) Evolutionary Changes in Cambridge Composite Cross Five of Barley. In: Cooper HD, Spillane C, Hodgkin T (eds), Broadening the genetic base of crop production. CABI, London, pp 271-282.

Idrissi O, Houasli C, Udupa SM, Keyser E de, van Damme P, Riek J de (2015) Genetic variability for root and shoot traits in a lentil (Lens culinaris Medik.) recombinant inbred line population and their association with drought tolerance. Euphytica 204:693-709. doi:10.1007/s10681-015-1373-8.

Jana S, Khangura BS (1986) Conservation of diversity in bulk populations of barley (Hordeum vulgare L.). Euphytica 35:761-776.

John J (2015) Developing a market for organic lentils. Quantitative insights from a farmer led producer group in Germany. M. Sc. Agr. Thesis, Alnarp.

Ladizinsky G (1993) Lentil domestication: On the quality of evidence and arguments. Economic Botany:60-64.

Lentil Genome Pre-Release, available online: http://knowpulse.usask.ca/portal/lentil-genome (accessed on 18 April 2017).

Lombardi M, Materne M, Cogan NOI, Rodda M, Daetwyler HD, Slater AT, Forster JW, Kaur S (2014) Assessment of genetic variation within a global collection of lentil (Lens culinaris Medik.) cultivars and landraces using SNP markers. BMC genetics 15:1-10. doi:10.1186/s12863-014-0150-3.

Materne M, Siddique K (2009) Agroecology and crop adaptation. In: Erskine W, Muehlbauer FJ, Sarker A, Sharma B (eds), The lentil: botany, production and uses. CAB International, Oxfordshire, pp 47-63.

Munoz N, Liu A, Kan L, Li M, Lam H (2017) Potential Uses of Wild Germplasms of Grain Legumes for Crop Improvement. Int. J. Mol. Sci. 18:1-28. doi:10.3390/ijms18020328. 
Negri V (2003) Landraces in central Italy: where and why they are conserved and perspectives for their on-farm conservation. Genetic Resources and Crop Evolution 50:871-885. doi:10.1023/A:1025933613279.

Paillard S, Goldringer I, Enjalbert J, Trottet M, David J, Vallavieille-Pope C de, Brabant P (2000) Evolution of resistance against powdery mildew in winter wheat populations conducted under dynamic management. II. Adult plant resistance. Theoretical and Applied Genetics 101:457-462. doi:10.1007/s001220051503.

Phillips SL, Wolfe MS (2005) Evolutionary plant breeding for low input systems. The Journal of Agricultural Science 143:245-255. doi:10.1017/S0021859605005009.

Piergiovanni AR (2000) The evolution of lentil (Lens culinaris Medik.) cultivation in Italy and its effects on the survival of autochthonous populations. Genetic Resources and Crop Evolution 47:305-314. doi:10.1023/A:1008789614680.

Reda A (2015) Lentil (Lens Culinaris Medikus) Current Status and Future Prospect of Production in Ethiopia. Advances in Plants \& Agriculture Research 2. doi:10.15406/apar.2015.02.00040.

Rhone B, Remoue C, Galic N, Goldringer I, Bonnin I (2008) Insight into the genetic bases of climatic adaptation in experimentally evolving wheat populations. Molecular Ecology 17:930-943. doi:10.1111/j.1365-294X.2007.03619.x.

Sadras VO (2007) Evolutionary aspects of the trade-off between seed size and number in crops. Field Crops Research 100:125-138. doi:10.1016/j.fcr.2006.07.004.

Sarker A, Erskine W (2006) Recent progress in the ancient lentil. The Journal of Agricultural Science 144:19-29. doi:10.1017/S0021859605005800.

Sarker A, Erskine W, Singh M (2005) Variation in shoot and root characteristics and their association with drought tolerance in lentil landraces. Genetic Resources and Crop Evolution 52:89-97. doi:10.1007/s10722-005-0289-x.

Schnell FW (1980) Aspekte der genetischen Diversität im Problemkreis der Pflanzenzüchtung. Göttinger Pflanzenzüchter-Seminar 4:5-15.

Silvertown J (1989) The paradox of seed size and adaptation. Trends in Ecology \& Evolution 4:24-26. doi:10.1016/0169-5347(89)90013-X.

Simmonds NW (1991) Selection for local adaptation in a plant breeding programme. Theoretical and Applied Genetics 82:363-367. doi:10.1007/BF02190624.

Sonnante G, Hammer K, Pignone D (2009) From the cradle of agriculture a handful of lentils. History of domestication. RENDICONTI LINCEI 20:21-37. doi:10.1007/s12210-009-0002-7.

Suneson CA (1956) An Evolutionary Plant Breeding Method. Agronomy Journal 48:188-191. doi:10.2134/agronj1956.00021962004800040012x.

Tin HQ, Berg T, Bjornstad A (2001) Diversity and adaptation in rice varieties under static (ex situ) and dynamic (in situ) management. Euphytica 122:491-502.

University of Hohenheim (2016) Linsenforschung in Hohenheim: Doppelpack für sichere Erträge, leichtere Ernte, höhere Qualität, https://www.unihohenheim.de/pressemitteilung?tx_ttnews\%5Btt_news\%5D=32569\&cHash=5d7df4cf2da9325658c13 c9cbefbe2fe (accessed on 19 April 2017). 
Veteläinen M, Negri V, Maxted N (2009) European landraces: On-farm conservation, management and use. Biodiversity Technical Bulletin No 15. Biodiversity International, Rome, Italy.

Wang L, Gruber S, Claupein W (2012) Optimizing lentil-based mixed cropping with different companion crops and plant densities in terms of crop yield and weed control. Organic Agriculture 2:79-87. doi:10.1007/s13165-012-0028-5.

Weedon O, Haak J, Brumlop S, Heinrich S, Finckh MR (2015) Vergleich der Adaptation von Winterweizenpopulationen mit unterschiedlichem Anbauhintergrund. 13. Wissenschaftstagung Ökologischer Landbau. doi:10.1007/978-3-658-09913-8_1.

Wolfe MS, Baresel JP, Desclaux D, Goldringer I, Hoad S, Kovacs G, Löschenberger F, Miedaner T, $\emptyset$ stergård H, Lammerts van Bueren ET (2008) Developments in breeding cereals for organic agriculture. Euphytica 163:323-346. doi:10.1007/s10681-008-9690-9.

Wolfe MS, Hinchsliffe KE, Clarke SM, Jones H, Haigh Z (2006) Evolutionary breeding of healthy wheat: from plot to farm. Aspects of Applied Biology 79:47-50.

Wong MML, Gujaria-Verma N, Ramsay L, Yuan HY, Caron C, Diapari M, Vandenberg A, Bett KE (2015) Classification and characterization of species within the genus lens using genotyping-by-sequencing (GBS). PloS one 10:e0122025. doi:10.1371/journal.pone.0122025.

Zeven AC (1998) Landraces: A review of definitions and classifications. Euphytica 104:127-139. doi:10.1023/A:1018303821680. 


\section{Performance of populations under site-SPeCific natural Selection}

\subsection{INTRODUCTION}

Today there is general agreement on the importance of plant genetic resources to safeguard future productivity (Hammer 2004). In situ conservation strategies may allow for evolutionary adaptation to sitespecific conditions and thus increase the future value of genetic resources, rather than preserving the status quo ex situ e.g. in gene banks. With the intensification and industrialization of agriculture, the seed market also became a professional industry providing modern professional farmers and gardeners of the so called industrialized western countries with modern high yielding cultivars. The collection of samples from landraces before they are replaced by commercial cultivars to preserve in gene banks is essential. Nevertheless, genetic erosion in ex situ collections was demonstrated for barley landraces by Parzies et al. (2000) and for cabbage (Brassica oleracea) by van Hintum et al. (2007). Rates of genetic erosion in Italy were calculated by Hammer and Laghetti (2005) and were shown to be higher for cereals than for pulses. Consequently, different concepts of a dynamic conservation of plant genetic resources are discussed and reviewed for its potential for site-specific adaptation and suitability for practical application in agriculture and horticulture (Bretting and Duvick 1997; Goldringer et al. 2001a; Hammer 2003; Hammer 2004). In situ management strategies of plant genetic resources should be regarded as valuable complementary methods to ex situ conservation. It depends on the species and their utilization, which of the strategies for conservation may be preferred (Berthaud 1997).

On-farm management of plant genetic resources is the 'in situ conservation practice' for crop plants and is widely applied in organic farming, on small scale farms, in home gardens, and on traditional farms of the developing world, where landraces are still grown. The main goals of on-farm management are the enhancement of crop biodiversity and the reduction of genetic erosion by improving the availability of neglected species and old cultivars and maintaining the cultural diversity and heritage of cultivated plant species in agriculture and horticulture (Negri et al. 2000; Becker et al. 2002). Wood and Lenné (1997) reviewed the evidence for the assumptions responsible for numerous publications promoting on-farm management of plant genetic resources, in response to the 'Convention on Biological Diversity' in 1992, partly based on misconceptions or undifferentiated alarmism. They proposed as an agenda for future research to include varietal (population) characterization and evaluation, selection and natural selection, the assessment of the genetic base and the entitative existence of local adaptation.

In the case of autogamous species, the effect of site-specific natural selection and random genetic drift in a diverse population would be expected to have a larger effect compared to a population of an allogamous species due to the limited recombination rate. Thus, possible adaptive selection to a specific environment would be achieved relatively faster given that diverse genotypes are present in the population. For wild populations of oats with an outcrossing rate of $1-12 \%$, Imam and Allard (1965) found geographical differentiation between and significant variability within populations and postulated that "The genetic system of wild oats thus appears to combine much of the flexibility of outbreeders with some of the ability of inbreeders to maintain specific highly adapted genotypes" leading "to the success [...] in occupying complex habitats". Harlan and Martini (1938) studied mixtures of barley varieties at several locations during a maximum of twelve years and found "a rapid elimination of the less adapted sorts". Studies on 
evolutionary changes in composite cross populations of barley were done in England (Ibrahim and Barrett 2001). In wheat populations under dynamic management in France, temporal evolution, selection, genetic drift, and differentiation in response to local conditions were studied (Enjalbert et al. 1999; Goldringer et al. 2001a; Goldringer et al. 2001b; Goldringer et al. 2006).

Another aspect of on-farm maintenance of diverse populations (e.g. composite cross populations) is the conservation of disease resistance genes and the use of co-evolutionary adaptation effects in the hostpathogen-relationship (de Smet et al. 1985; Allard 1990; Paillard et al. 2000; Finckh et al. 2000; Finckh 2007; Finckh 2008; Finckh et al. 2009). Furthermore, for low-input and organic farming, on-farm management and selection, e.g. in participatory plant breeding programs, can help to meet the needs of growers in special, marginal environments, that are often overlooked by conventional breeders (Murphy et al. 2005; Wolfe et al. 2008; Lammerts van Bueren et al. 2011; Rivière et al. 2013).

Ongoing research on population development and adaption of a diverse composite cross population of wheat grown at several locations across Europe is done at the University of Kassel in Witzenhausen (Finckh et al. 2009; Brumlop and Finckh 2013; Weedon et al. 2015). Another project with barley is carried out at the Julius-Kühn-Institut in Quedlinburg, Germany, in a barley population developed by multi-parent advanced generation intercross (MAGIC, as suggested by Cavanagh et al. (2008)) to be grown subsequently for at least eight years at twelve contrasting locations (Léon et al. 2008; Frese et al. 2012; Frese and Germeier 2016).

On-farm projects to explore the effect of local adaptation involving lentil are not known to us. Studies on phenotypic and genetic variation and environmental effects on lentil are known from the Mediterranean area (e.g. Erskine and El Ashkar 1993, Siddique et al. 1998, Sarker et al. 2007, Sarker et al. 2010). The response to conventional and organic farming practice on various lentil varieties has been studied by Vlachostergios and Roupakias (2008) and observed interaction of grain yield and the farming practice suggesting breeders to test their material under both conditions. Lentil is a neglected leguminous crop in Germany, although its seed is still a popular and traditional food.

In this chapter, we examine the effect of natural selection for site-specific adaption. We compare the performance of the three populations per cultivar at the three sites of selection to answer the question, whether differentiation in agronomical, phenological, and morphological traits can be observed for populations selected at three contrasting farms for ten generations. Additionally, we compare the initial population with populations after five and after ten generations of natural selection to study their temporal development. 


\subsection{MATERIALS AND MethodS}

\section{PLANT Genetic MATERIALS}

Three old lentil cultivars were selected and multiplied in Göttingen in 1996 after a screening of multiple accessions of central European origin maintained at the gene bank of the Institute of Plant Genetics and Crop Plant Research (IPK) in Gaterleben, Germany (Horneburg and Becker 1998; Horneburg and Becker 2008). During maintenance for 38 to 47 years, irregular regeneration was done 8 to 17 times (Horneburg 2003b). The origin, location and frequency of regeneration for the three cultivars are documented by Horneburg (2003b). Cultivar 'Pisarecka Perla', kept under accession coding LENS 122, has a mean seed weight of approximately $60 \mathrm{mg}$ with visible variation in seed size and color ranging from large beige seeds to smaller partially black spotted or striped seeds. It has relatively large, white flowers and a half erect growth and relatively strong, stiff, lignified branches. Cultivar 'Schwarze Linse' (LENS 106) has a mean seed weight of approximately $25 \mathrm{mg}$ and small, black, round seeds, erect growth with less strong branches, and small violet flowers. Cultivar 'Gestreifte Linse' (LENS 103) has an average seed weight of approximately 37 $\mathrm{mg}$, green-black-patterned seeds, overhanging growth due to particularly long side-shoots, and white flowers.

Based on the passport data is was not possible to differentiate between landraces or cultivars. Thus, when referring in general to one of the three cultivars, we will use the term 'cultivar' and the abbreviations PP, $\mathrm{SL}$, and GL for the cultivar names. Whereas, within a specific cultivar, when comparing the initial material and material after several years under natural selection, it will be referred to as 'population'. The generations under natural selection will be assigned with 0,5 , and 10 .

Seeds from the multiplication of the initial populations in Göttingen 1996 were given to three farms and repeatedly grown from 'farm-saved-seeds' for five years (1997-2001). The number of sown seeds at the farms varied. In 1997, 100 seeds ( 25 plants $\mathrm{m}^{-2}$ ) were sown, in 1998 it was 400 seeds ( 66 plants $\mathrm{m}^{-2}$ ), and approximately 300 seeds (100 plants $\mathrm{m}^{-2}$ ) in 1999 and 2000. In 2001, larger plots of $5 \mathrm{~m}^{2}$ with 140-150 seeds $\mathrm{m}^{-2}$ were sown in three replications for the first phenotypic evaluation in the fifth generation of natural selection (Horneburg 2003b; Horneburg and Becker 2008). Cultivation at the three farms continued from farm-saved-seeds in 2006 until 2010 for another five generations under natural selection with 500 seeds each year on $5 \mathrm{~m}^{2}$ plots.

From the seeds harvested in $2010\left(10^{\text {th }}\right.$ generation) at the selection sites, the seeds from $2001\left(5^{\text {th }}\right.$ generation), and seeds stored at the IPK Gatersleben from the last regeneration of the initial material in 1996 in Göttingen, multiplication plots were conducted in 2014 at Reinshof in low planting density under a rainout shelter to reduce the effect of natural selection to a minimum and to ensure optimal seed quality by protecting the plants from rain during ripening. In this way, we were able to obtain enough seed material of good and equal quality for all populations to establish the experiments in 2015 and 2016. Planting of the multiplication plots was done with 80 seeds $\mathrm{m}^{-2}$ on a $6 \mathrm{~m}^{2}$ plot per population (minimum 480 seeds) in four rows with $35 \mathrm{~cm}$ spacing between rows and approximately $5 \mathrm{~cm}$ plant to plant distance within rows. To account for the lower average seed yield per plant in Pisarecka Perla compared to the other cultivars, the 'initial population' of Pisarecka Perla was multiplied in two replications (two plots with a total of minimum 960 seeds) to guarantee for enough seeds from the multiplication. The rainout shelter 
was covered on $15^{\text {th }}$ of July, one month before the harvest of the complete plots when completely ripe on $18^{\text {th }}$ of August.

\section{LOCATIONS AND CLIMATIC CONDITIONS}

The farms Reinshof, Schönhagen, Tangsehl, and Darzau are situated in central and northern Germany and differ in their pedoclimatic conditions (TABLE 2.1). The three sites of selection from 1997 until 2010 were Reinshof, Schönhagen, and Tangsehl. For our field tests in 2015 and 2016, we switched 4km north of Tangsehl to the farm Darzau. Reinshof is the experimental station of the Georg-August-University at the southern periphery of Göttingen. It is characterized by a very fertile, deep loess soil in the valley of the river Leine. In Schönhagen, $30 \mathrm{~km}$ south Göttingen, lentil were grown until 1958, and it has poor, shallow, and stony calcareous clay soil (Horneburg 2003a; Horneburg and Becker 2008). Tangsehl and Darzau are situated approximately $200 \mathrm{~km}$ north of Göttingen near the river Elbe and have slightly acid and very sandy soils with flint stones. Locations in Schönhagen, Tangsehl, and Darzau are managed by organic (biodynamic) standards, the experimental field plots at Reinshof were conducted on fields under conventional agricultural management without application of fungicides and mineral fertilizer.

In the following, for the sake of convenience, we will refer to 'Tangsehl' as both the 'selection site' and the 'testing site'. The locations will be abbreviated with R, S, and T.

Climatic conditions measured by the long-term mean temperature and the annual precipitation differ slightly between the locations, presumably mostly influenced by their altitude and latitude (TABLE 2.1). Compared to 2015, there was considerably higher temperature and higher precipitation during May and June at all locations in 2016 (TABLE 2.2). Season length differs between locations with about three weeks between Tangsehl and Schönhagen (TABLE 2.3).

TABLE 2.1 The selection and test sites (updated from Horneburg (2003b))

\begin{tabular}{|c|c|c|c|c|}
\hline & Reinshof & Schönhagen & Tangsehl & Darzau \\
\hline Geograph. coordinates & $\begin{array}{c}51^{\circ} 29^{\prime} 50^{\prime \prime} \mathrm{N} / \\
9^{\circ} 55^{\prime} 53^{\prime \prime} \mathrm{E}\end{array}$ & $\begin{array}{l}51^{\circ} 21^{\prime} 2^{\prime \prime} \mathrm{N} / \\
10^{\circ} 0^{\prime} 44^{\prime \prime} \mathrm{E}\end{array}$ & $\begin{array}{c}53^{\circ} 10^{\prime} 31^{\prime \prime} \mathrm{N} / \\
10^{\circ} 52^{\prime} 50^{\prime \prime} \mathrm{E}\end{array}$ & $\begin{array}{l}53^{\circ} 12^{\prime} 9^{\prime \prime} \mathrm{N} / \\
10^{\circ} 52^{\prime} 40^{\prime \prime} \mathrm{E}\end{array}$ \\
\hline Altitude & $150 \mathrm{~m}$ & $330-360 \mathrm{~m}$ & $40 \mathrm{~m}$ & $30 \mathrm{~m}$ \\
\hline Annual precipitation & $651 \mathrm{~mm}^{\text {a) }}$ & $773 \mathrm{~mm}^{\mathrm{b})}$ & $617 \mathrm{~mm}^{\mathrm{c})}$ & $713 \mathrm{~mm}^{\mathrm{d})}$ \\
\hline Long-term mean temp. & $9.2^{\circ} \mathrm{C}^{\mathrm{a})}$ & $8.1^{\circ} \mathrm{C}^{\mathrm{e})}$ & $8.6^{\circ} \mathrm{C}^{\mathrm{f})}$ & $9.2^{\circ} \mathrm{C}^{\mathrm{d})}$ \\
\hline Farming strategy & conventional & bio-dynamic & bio-dynamic & bio-dynamic \\
\hline Preceding crop & wheat, sugarbeet & oat, grass & - & grass, rye \\
\hline Soil type & $\begin{array}{c}\text { Loess } \\
\text { deep loam }\end{array}$ & $\begin{array}{l}\text { Leptosol } \\
\text { shallow clay on } \\
\text { limestone }\end{array}$ & $\begin{array}{l}\text { Podsol } \\
\text { glacial sand with } \\
\text { flint stones }\end{array}$ & $\begin{array}{l}\text { Cambisol } \\
\text { glacial sand with } \\
\text { flint stones }\end{array}$ \\
\hline Soil value (Ackerzahl) & $82-90$ & $23-30$ & $33-36$ & - \\
\hline Humus content [\%] & 2.0 & 4.2 & 1.8 & 1.1 \\
\hline $\mathrm{pH}$-value (CaCl) & 7.0 & 7.5 & 5.0 & 4.9 \\
\hline P2O5 [mg $100 g^{-1}$ soil] & 5.2 & 1.2 & 3.8 & 9 \\
\hline $\mathrm{K} 2 \mathrm{O}\left[\mathrm{mg} 100 \mathrm{~g}^{-1}\right.$ soil $]$ & 20 & 17 & 14 & 3 \\
\hline \\
\hline \multicolumn{5}{|c|}{ b) Long-term mean (1981-2010) of the meteorological station Bad Sooden, Allendorf, Deutscher Wetterdienst } \\
\hline \multicolumn{5}{|c|}{ c) Long-term mean (1989-1999) at the farm station Tangsehl } \\
\hline \multicolumn{5}{|c|}{ d) Long-term mean (1981-2010) of the meteorological station Wendisch-Evern, Deutscher Wetterdienst } \\
\hline \multicolumn{5}{|c|}{ e) Long-term mean (1981-2010) of the meteorological station Leinefelde, Deutscher Wetterdienst } \\
\hline \multicolumn{5}{|c|}{ f) Long-term mean (1961-1990) of the meteorological station Lüchow, Wendland, Deutscher Wetterdienst } \\
\hline
\end{tabular}


TABLE 2.2 Temperature and precipitation at the test sites from April - August 2015 and 2016

\begin{tabular}{|c|c|c|c|c|c|c|c|}
\hline & Year & Apr & May & Jun & Jul & Aug & Mean $\left[{ }^{\circ} \mathrm{C}\right] /$ Sum $[\mathrm{mm}]$ \\
\hline \multicolumn{8}{|l|}{ Reinshof } \\
\hline \multirow[t]{2}{*}{ Temperature $\left[{ }^{\circ} \mathrm{C}\right]^{\text {a) }}$} & 2015 & 8.4 & 12.2 & 15.4 & 18.7 & 19.6 & 14.8 \\
\hline & 2016 & 8.1 & 13.8 & 17.2 & 18.6 & 17.9 & 15.1 \\
\hline \multirow[t]{2}{*}{ Precipitation [mm] ${ }^{\text {a) }}$} & 2015 & 46.5 & 30 & 23.1 & 91 & 113.7 & 304.3 \\
\hline & 2016 & 28.4 & 41.4 & 113 & 43 & 40.5 & 266.3 \\
\hline \multicolumn{8}{|l|}{ Schönhagen } \\
\hline \multirow[t]{2}{*}{ Temperature $\left[{ }^{\circ} \mathrm{C}\right]{ }^{\mathrm{b})}$} & 2015 & 7.9 & 11.5 & 14.7 & 18.4 & 19.6 & 14.4 \\
\hline & 2016 & 7.3 & 13.0 & 16.5 & 18.2 & 17.6 & 14.5 \\
\hline \multirow[t]{2}{*}{ Precipitation [mm] ${ }^{\mathrm{c})}$} & 2015 & 45.2 & 24.5 & 22.9 & 66.3 & 120.8 & 279.7 \\
\hline & 2016 & 34.9 & 36.3 & 118.6 & 43.3 & 16.6 & 249.7 \\
\hline \multicolumn{8}{|l|}{ Tangsehl } \\
\hline \multirow[t]{2}{*}{ Temperature $\left[{ }^{\circ} \mathrm{C}\right]{ }^{\mathrm{d})}$} & 2015 & 8.5 & 12.0 & 16.0 & 18.9 & 19.8 & 15.0 \\
\hline & 2016 & 8.3 & 15.5 & 18.4 & 19.3 & 17.8 & 15.8 \\
\hline \multirow[t]{2}{*}{ Precipitation [mm] ${ }^{\text {e) }}$} & 2015 & 26.2 & 25.8 & 26.0 & 99.9 & 94.0 & 271.9 \\
\hline & 2016 & 50.9 & 41.1 & 76.8 & 50.1 & 34.3 & 253.2 \\
\hline $\begin{array}{l}\text { a) Data source: Meteorolog } \\
\text { b) Data source: Meteorolog } \\
\text { c) Data source: Meteorolog } \\
\text { d) Data source: Meteorolog } \\
\text { e) Data source: Meteorolog }\end{array}$ & $\begin{array}{l}\text { tion Göt } \\
\text { tion Lei } \\
\text { tion Bac } \\
\text { tion Len } \\
\text { tion Ble }\end{array}$ & $\begin{array}{l}\text { en, Deu } \\
\text { d, Deut } \\
\text { den-All } \\
\text { (Elbe), L } \\
\text { e-Walm }\end{array}$ & $\begin{array}{l}\text { er Wett } \\
\text { r Wette } \\
\text { orf, Deu } \\
\text { scher W } \\
\text { g, Deut }\end{array}$ & $\begin{array}{l}\text { enst (wn } \\
\text { enst (ww } \\
\text { er Wette } \\
\text { erdienst } \\
\text { er Wette }\end{array}$ & $\begin{array}{l}\text { Iwd.de/ } \\
\text { wd.de/V } \\
\text { enst (wn } \\
\text { w.dwd. }\end{array}$ & $\begin{array}{l}\text { STE) } \\
\text { TTE) } \\
\text { dwd.de/V } \\
\text { WESTE) } \\
\text { dwd.de/M }\end{array}$ & STE) \\
\hline
\end{tabular}

\section{Phenotyping}

Field plots including the initial population and the populations after five and ten generations from the three locations $(1 \times 3+3 \times 3+3 \times 3=21$; and additional two selections per cultivar for extreme seed size evaluated separately in Chapter 4) were sown in a split plot design (main plot = cultivar) with four replications. Plots were sown between 12-20 April 2015 and 2016 at all three locations with 100 seeds $\mathrm{m}^{-2}$, six rows with a row to row distance of $24 \mathrm{~cm}$ and a plot size of $5 \mathrm{~m}^{2}(1.5 \times 3.35 \mathrm{~m})$.

Within the central part of the $5 \mathrm{~m}^{2}$ field plots, the inner four of the six rows were pitched with sticks for a length of one meter and the number of plants in these rows within that length were counted for field emergence two to three weeks after sowing. At harvest, plants carrying pods were recounted within the same area of the plots to get a measure for the number of plants contributing to yield and to calculate a subsequent survival rate.

As morphological marker, hypocotyl color, as it is visible after field emergence of the seedling, was recorded. For specific populations which showed segregation for this trait, the number of red colored seedlings was counted.

Leaf size was measured shortly before or at the beginning of flowering. Leaves were taken from the field plots and stored cool between wet papers and measured within the next 48 hours. The leaf to be taken for measurement was defined to be the third leaf from the top characterized by a darker green compared to most upper leaves and thus being full-grown, no rolled or curved surface of the leaflets, and for most genotypes without a tendril at the leaf apex. The measuring was done using the Leaf Area Meter (LI-3100, LI-COR ${ }^{\circledR}$ ) with an area resolution of $1 \mathrm{~mm}^{2}$. 
Flowering was scored on a scale from $0-4(0 \%,>0 \leq 1 \%,>1 \leq 10 \%$, up to $50 \%$, and $>50 \%$ of the plants flowering) starting when first flowers were observed continuously every second day until full flowering was reached. Scores of in total five dates were summed to a 'flowering time score sum' (FTsum).

Lodging was scored if possible e.g. after heavy rainfalls and/or winds it was done on a 1 - 9 scale (not lodging until fully lodging).

Ripening was measured by scoring from $1-9$ for the amount of ripe pods on the plants. A value of 1 represents no ripe pods and the following values $2-9$ correspond to approximately $1 \leq 10,>10 \leq 30,>30 \leq 40$, $>40 \leq 50,>50 \leq 70,>70 \leq 90,>90$ with still partly fresh plants, and $>90 \%$ ripe pods with completely dead straw, respectively.

The whole plot was harvested by hand and weeds were removed. The complete aboveground biomass of lentil was put into sacks and dried at the farm on a hot air dryer at $25-30^{\circ} \mathrm{C}$. Seed and straw weight was taken when threshing dried plants. Threshing was done by a non-mobile thresher (Pelz K35, WachtbergVillip, Germany). Seed and straw yield was then calculated in $\left[\mathrm{g} \mathrm{m}^{-2}\right]$ and corrected for $86 \%$ dry matter content. The total harvest weight of either straw or seeds are multiplied by the actual total dry matter content and then divided by $86 \%$ dry matter content. Total dry matter content was obtained from one test entry per cultivar, replication, and location by drying seed and straw samples at $105^{\circ} \mathrm{C}$ for $12 \mathrm{~h}$. Since the material was dried after harvest and the material from a location was subsequently threshed in a short time frame, little variation was expected between entries within a cultivar from the same location and replication. Thus, this procedure was solely to monitor for any unexpected variation and for this the same population ( $10^{\text {th }}$ generation from Reinshof) was chosen for each cultivar as the 'check entry'.

Thousand kernel weight was calculated after threshing and bagging the seeds from four times 100 seeds.

TABLE 2.3 Dates of sowing and harvest and the season length for the performance trials.

\begin{tabular}{llccc}
\hline Year & Location & Date of sowing & Harvest date & Season length [days] \\
\hline 2015 & Reinshof & 14. April & 13. August & 121 \\
& Schönhagen & 14.-15. April & 24. August & 131 \\
& Tangsehl & 20. April & 6. August & 108 \\
\hline \multirow{2}{2}{2016} & Reinshof & 12. April & 10.-11. August & 121 \\
& Schönhagen & 20. April & 22. August & 124 \\
& Tangsehl & 14. April & 29. July & 106 \\
\hline
\end{tabular}




\section{STATISTICAL ANALYSIS}

Data was evaluated by the analysis of variance (ANOVA) in PLABSTAT (Version 3Bwin, Utz 2011) and mean values were calculated in the same software. The following general model was applied:

$x_{i j k l m}=\mu+y_{i}+r_{m}+y r_{i m}+l_{j}+y\left|r_{i j m}+c_{k}+y l c r_{i j k m}+p_{l}+y l c p r_{i j k l m}+y l_{i j}+y c_{i k}+\right| c_{j k}+y p_{i l}+\mid p_{j l}+c p_{k l}+y l c_{i j k}+y l p_{i j l}$ where $x_{i j k l m}$ is the observed value, $\mu$ is the general mean of the experiment, and $y_{i}, l_{j}, c_{k}, p_{1}$, and $r_{m}$ are the effects of year, location, cultivar, population, and replication, respectively. The replication is a random factor within year, location, and cultivar. Possible interactions are considered up to the three-way level

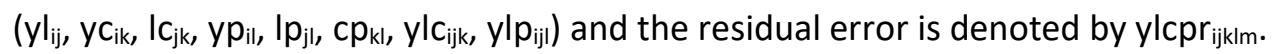

The model is reduced by the factors 'location' and 'cultivar' or the factor 'cultivar' only, to analyze subsets of the populations separately per cultivar and location to reveal the site-specific or temporal effects of populations in generation ten or populations in generation 0,5 , and 10 , respectively.

Post-hoc mean comparisons were done by Tukey's HSD (honestly significant difference) test. The HSD values were calculated 'by hand' in Microsoft Excel (Version 2010) using the mean squares and degrees of freedoms (or alternatively the standard errors) given in the ANOVA table by PLABSTAT and the respective $q$-value from the 'Studentized $Q$ table' for a level of significance of $5 \%(P=0.05)$; in few cases for $10 \%$ $(P=0.1)$. 


\subsection{ResUlts}

The two experimental years differ significantly for yield traits, flowering time, and ripening. The effect of the location was larger compared to the year effect for all traits except for flowering, as shown by the respective variance components in TABLE 2.4 , and was highly significant for location for all traits. The factors cultivar and population had a significant effect in the ANOVA for all traits, as well as the interactions between them. The effect of the cultivar and interactions of cultivar with location and with year was significant for all traits. Heritability values calculated for the population effect across years, locations, and cultivars range between 97.47 and 99.85 in straw yield and flowering, respectively. The second highest heritability was observed for seed weight with 99.79 in the same analysis on the whole data set.

TABLE 2.4 Variance components from ANOVA calculated for year $(\mathrm{Y})$, location (L), cultivar $(\mathrm{C})$, population $(P)$, and replication $(R)$ and all interactions with their significance in the F-test ${ }^{\mathrm{a}}{ }^{\text {, }}$, the degrees of freedom (DF) for each source of variation, and the heritability calculated for P for each trait: kernel yield (KY), seed yield (SY), total yield (TY), harvest index (HI), seed weight (SW), sum of flowering scores (FTsum), and ripening (RP).

\begin{tabular}{lcccccccc}
\hline Source & DF & KY & SY & TY & HI & SW & FTsum & RP \\
\hline Y & 1 & $2352^{* *}$ & $4963^{* *}$ & $14159^{* *}$ & $0.392^{+}$ & $0^{\text {b) }}$ & $21.25^{* *}$ & $0.204^{* *}$ \\
L & 2 & $9048^{* *}$ & $32078^{* *}$ & $75183^{* *}$ & $12.96^{* *}$ & $1.47^{* *}$ & $7.354^{* *}$ & $1.427^{* *}$ \\
LY & 2 & $595.4^{* *}$ & $1257^{* *}$ & $3585^{* *}$ & $2.865^{* *}$ & $1.29^{* *}$ & $5.453^{* *}$ & $0.253^{* *}$ \\
R:LY & 18 & $81.11^{*}$ & $393.7^{* *}$ & $903.8^{* *}$ & 0.210 & $0.50^{* *}$ & $0.612^{* *}$ & $0.063^{* *}$ \\
\hline C & 2 & $1737^{* *}$ & $1062^{* *}$ & $5525^{* *}$ & $42.05^{* *}$ & $165.77^{* *}$ & $15.12^{* *}$ & $0.606^{* *}$ \\
CL & 4 & $320.3^{* *}$ & $567.2^{* *}$ & $1614^{* *}$ & $2.820^{* *}$ & $1.49^{* *}$ & $0.249^{* *}$ & $0.104^{* *}$ \\
CY & 2 & $54.78^{*}$ & $251.0^{* *}$ & $553.2^{* *}$ & $2.203^{* *}$ & $0.15^{*}$ & $5.968^{* *}$ & 0.008 \\
CLY & 4 & $256.0^{* *}$ & $597.9^{* *}$ & $1494^{* *}$ & $2.635^{*}$ & $1.39^{* *}$ & $1.204^{* *}$ & $0.387^{* *}$ \\
RC:LY & 36 & $198.9^{* *}$ & 42.27 & $327.1^{* *}$ & $2.202^{* *}$ & $0.25^{* *}$ & $0.448^{* *}$ & $0.087^{* *}$ \\
\hline P & 6 & $332.1^{* *}$ & $1055^{* *}$ & $2582^{* *}$ & $21.79^{*}$ & $54.63^{* *}$ & $10.64^{* *}$ & $0.559^{* *}$ \\
PC & 11 & $797.6^{* *}$ & $2620^{* *}$ & $6261^{* *}$ & $74.64^{* *}$ & $178.76^{* *}$ & $33.31^{* *}$ & $1.781^{* *}$ \\
PL & 12 & 4.415 & 0.406 & 0 & 0.205 & 0 & $0.070^{* *}$ & 0.001 \\
PY & 6 & 8.449 & 22.66 & $77.76^{+}$ & 0 & 0 & $0.102^{* *}$ & 0.001 \\
PLY & 12 & 0 & 71.22 & 116.9 & 0 & 0 & 0 & 0 \\
RPC:LY & 361 & 404.2 & 1974 & 2735 & 10.09 & 1.36 & 1.148 & 0.224 \\
\hline Heritability (P) & 98.34 & 97.47 & 98.55 & 99.36 & 99.79 & 99.85 & 99.45 \\
\hline
\end{tabular}

a) Significance levels are denoted with ${ }^{* *},{ }^{*},{ }^{+}$for P-values $=0.01,0.05,0.1$, respectively.

b) Negative estimates

Seed and straw yield mean values differ significantly between cultivars and locations in 2015 and 2016 (TABLE 2.5). In 2016 yield was lower by approximately 40\% with the highest yield reduction compared to the previous year in Schönhagen and for Schwarze Linse. In both years, the location Reinshof yields highest and the cultivar Gestreifte Linse yields highest in both years in seed and straw at all locations.

Interactions of cultivar and year can be observed e.g. in straw yield at Reinshof, where PP yields lowest in 2015 , but in the following year the same cultivar yields significantly more compared to SL (TABLE 2.5). Seed weight was highest in both years in Tangsehl. 
TABLE 2.5 Mean values per year, cultivar, and test location in 2015 and 2016 for all traits.

\begin{tabular}{|c|c|c|c|c|c|c|}
\hline \multirow[b]{2}{*}{ Trait } & \multirow[b]{2}{*}{ Year } & \multirow[b]{2}{*}{ Cultivar } & \multicolumn{3}{|c|}{ Test location } & \multirow[b]{2}{*}{ Mean } \\
\hline & & & Reinshof & Schönhagen & Tangsehl & \\
\hline \multirow{8}{*}{$\begin{array}{l}\text { Seed yield } \\
{\left[\mathrm{gm}^{-2}\right]}\end{array}$} & 2015 & $\mathrm{PP}$ & 237.7 a $c^{\text {a) }}$ & $127.5 \mathrm{a} b$ & 54.0 a $a$ & $139.7 \mathrm{a}$ \\
\hline & & SL & $279.8 \mathrm{bc}$ & $150.5 \mathrm{~b} b$ & $76.3 \mathrm{~b} a$ & $168.9 \mathrm{~b}$ \\
\hline & & $\mathrm{GL}$ & 320.2 c c & $231.4 c b$ & $108.8 \mathrm{c} \mathrm{a}$ & $220.1 c$ \\
\hline & & Mean & $279.2 c$ & $169.8 b$ & $79.7 a$ & 176.2 \\
\hline & 2016 & $\mathrm{PP}$ & $170.0 \mathrm{a} b$ & $45.5 \mathrm{ba}$ & 35.6 a $a$ & $83.7 \mathrm{a}$ \\
\hline & & SL & $185.0 \mathrm{~b} b$ & 33.7 a $a$ & 40.1 a $a$ & $86.3 \mathrm{a}$ \\
\hline & & $\mathrm{GL}$ & 299.3 c c & $119.3 c b$ & $65.3 \mathrm{~b} \mathrm{a}$ & $161.3 \mathrm{~b}$ \\
\hline & & Mean & $218.1 \mathrm{c}$ & $66.2 b$ & $47.0 a$ & 110.4 \\
\hline \multirow{8}{*}{$\begin{array}{l}\text { Straw yield } \\
{\left[\mathrm{gm}^{-2}\right]}\end{array}$} & 2015 & $\mathrm{PP}$ & 435.8 a c & $220.1 \mathrm{a} b$ & 84.8 a $a$ & $246.9 a$ \\
\hline & & $\mathrm{SL}$ & $479.1 \mathrm{bc}$ & $215.5 a b$ & $113.6 \mathrm{~b} \mathrm{a}$ & $269.4 \mathrm{~b}$ \\
\hline & & $\mathrm{GL}$ & $477.2 \mathrm{bc}$ & $300.3 \mathrm{~b} b$ & $119.7 \mathrm{~b} a$ & $299.1 \mathrm{c}$ \\
\hline & & Mean & $464.0 \mathrm{c}$ & $245.3 b$ & $106.0 a$ & 271.8 \\
\hline & 2016 & $\mathrm{PP}$ & $370.5 \mathrm{~b} \mathrm{~b}$ & 58.1 a $a$ & 42.1 a $a$ & $156.9 \mathrm{a}$ \\
\hline & & SL & 331.4 a $b$ & 54.6 a $a$ & 60.8 a $a$ & $148.9 \mathrm{a}$ \\
\hline & & $\mathrm{GL}$ & $455.6 \mathrm{c} b$ & $161.9 \mathrm{~b} b$ & 57.1 a $a$ & $224.9 \mathrm{~b}$ \\
\hline & & Mean & $385.8 \mathrm{c}$ & $91.5 b$ & $53.4 a$ & 176.9 \\
\hline \multirow{8}{*}{$\begin{array}{l}\text { Total yield } \\
{\left[\mathrm{gm}^{-2}\right]}\end{array}$} & 2015 & $\begin{array}{l}\mathrm{PP} \\
\end{array}$ & $673.5 \mathrm{ac}$ & $347.6 \mathrm{a} b$ & 138.8 a $a$ & $386.6 \mathrm{a}$ \\
\hline & & SL & $758.8 \mathrm{bc}$ & 365.9 a $b$ & $189.9 \mathrm{~b} \mathrm{a}$ & $438.2 \mathrm{~b}$ \\
\hline & & $\mathrm{GL}$ & $797.4 \mathrm{cc}$ & $531.7 \mathrm{~b} b$ & $228.5 \mathrm{c} a$ & $519.2 \mathrm{c}$ \\
\hline & & Mean & $743.2 c$ & $415.1 b$ & $185.7 a$ & 448.0 \\
\hline & 2016 & $\mathrm{PP}$ & $540.5 \mathrm{~b} \mathrm{~b}$ & 103.5 a $a$ & 77.7 a $a$ & $240.6 \mathrm{a}$ \\
\hline & & $\mathrm{SL}$ & 516.4 a $b$ & 88.3 a $a$ & $100.9 \mathrm{~b} \mathrm{a}$ & $235.2 \mathrm{a}$ \\
\hline & & $\mathrm{GL}$ & 754.9 c c & $281.2 \mathrm{~b} b$ & $122.4 \mathrm{~b} \mathrm{a}$ & $386.2 \mathrm{~b}$ \\
\hline & & Mean & $603.9 \mathrm{c}$ & $157.7 b$ & $100.4 a$ & 287.3 \\
\hline \multirow{8}{*}{$\begin{array}{l}\text { Harvest } \\
\text { index }\end{array}$} & 2015 & $\mathrm{PP}$ & 30.15 a $a$ & $31.2 \mathrm{a} a b$ & 33.08 a $b$ & $31.5 \mathrm{a}$ \\
\hline & & $S L$ & $36.76 \mathrm{~b} \mathrm{a}$ & $41.07 \mathrm{~b} b$ & $40.29 \mathrm{~b} b$ & $39.4 \mathrm{~b}$ \\
\hline & & $\mathrm{GL}$ & $40.09 \mathrm{c} a$ & $43.42 \mathrm{c} \mathrm{b}$ & $47.63 \mathrm{cc}$ & $43.7 \mathrm{c}$ \\
\hline & & Mean & $35.7 a$ & $38.6 a b$ & $40.3 b$ & 38.2 \\
\hline & 2016 & PP & 26.09 a $a$ & $35.21 a b$ & 37.09 a c & $32.8 \mathrm{a}$ \\
\hline & & $S L$ & $35.7 \mathrm{~b} \mathrm{a}$ & $38.09 \mathrm{~b} b$ & $39.86 \mathrm{bc}$ & $37.9 \mathrm{~b}$ \\
\hline & & $\mathrm{GL}$ & $39.61 \mathrm{c} a$ & $46.57 \mathrm{c} \mathrm{b}$ & $53.46 \mathrm{cc}$ & $46.5 \mathrm{c}$ \\
\hline & & Mean & $33.8 a$ & $40.0 \mathrm{~b}$ & $43.5 c$ & 39.1 \\
\hline
\end{tabular}

a) Mean values followed by the same letter are not significantly different in Tukey's-HSD test at $P=0.05$;

small letters for column-wise and small italic letters for row-wise comparisons of three mean values.

Table continues on the following page. 
Table 2.5 continued.

\begin{tabular}{|c|c|c|c|c|c|c|}
\hline \multirow[b]{2}{*}{ Trait } & \multirow[b]{2}{*}{ Year } & \multirow[b]{2}{*}{ Cultivar } & \multicolumn{3}{|c|}{ Test location } & \multirow[b]{2}{*}{ Mean } \\
\hline & & & Reinshof & Schönhagen & Tangsehl & \\
\hline Seed & 2015 & PP & $45.78 \mathrm{ca}$ & $51.95 c b$ & $51.17 c b$ & $49.63 \mathrm{c}$ \\
\hline weight & & $\mathrm{SL}$ & 24.06 a $a$ & 24.17 a $a$ & 23.89 a $a$ & $24.04 \mathrm{a}$ \\
\hline \multirow[t]{6}{*}{ [mg] } & & GL & $34.37 \mathrm{~b} \mathrm{a}$ & $36.94 \mathrm{~b} b$ & $36.41 \mathrm{~b} b$ & $35.91 b$ \\
\hline & & Mean & $34.74 a$ & $37.69 b$ & $37.16 b$ & 36.53 \\
\hline & 2016 & PP & $47.23 \mathrm{ca}$ & $49.33 c b$ & 50.92 c c & $49.16 \mathrm{c}$ \\
\hline & & SL & 22.20 a $a$ & 23.07 a $a$ & $24.53 a b$ & $23.27 \mathrm{a}$ \\
\hline & & GL & $36.72 \mathrm{~b} b$ & $33.89 \mathrm{~b} \mathrm{a}$ & $38.24 \mathrm{~b} \mathrm{c}$ & $36.28 b$ \\
\hline & & Mean & $35.38 a$ & $35.43 a$ & $37.90 \mathrm{~b}$ & 36.24 \\
\hline Flowering & & PP & $17.78 \mathrm{ba}$ & $17.14 \mathrm{ba}$ & $24.15 \mathrm{~b} b$ & $19.69 \mathrm{~b}$ \\
\hline \multirow[t]{7}{*}{ score sum } & & SL & $22.70 \mathrm{cb}$ & $20.30 \mathrm{c} a$ & $29.30 \mathrm{cc}$ & $24.10 \mathrm{c}$ \\
\hline & & GL & 12.64 a $a$ & 10.86 a $a$ & 16.68 a $b$ & $13.39 a$ \\
\hline & & Mean & $17.71 a$ & $16.10 a$ & $23.38 b$ & 19.06 \\
\hline & 2016 & $\mathrm{PP}$ & $21.30 \mathrm{~b} \mathrm{a}$ & $24.11 \mathrm{a} b$ & 25.09 a $c$ & 23.50 \\
\hline & & $\mathrm{SL}$ & $26.71 \mathrm{c} a$ & $28.98 c b$ & $30.23 \mathrm{cc}$ & 28.64 \\
\hline & & GL & 19.79 a $a$ & $25.61 \mathrm{~b} b$ & $26.39 \mathrm{~b} b$ & 23.93 \\
\hline & & Mean & $22.60 a$ & $26.23 b$ & $27.24 \mathrm{c}$ & 25.36 \\
\hline Ripening & 2015 & PP & 5.82 a $b$ & 4.26 a $a$ & 5.76 a $b$ & $5.28 \mathrm{a}$ \\
\hline \multirow[t]{7}{*}{ score } & & SL & $6.41 \mathrm{~b} b$ & $5.86 \mathrm{c} a$ & $8.23 \mathrm{cc}$ & $6.83 \mathrm{~b}$ \\
\hline & & GL & $6.73 \mathrm{~b} b$ & $5.36 \mathrm{~b} \mathrm{a}$ & $7.84 \mathrm{bc}$ & $6.64 \mathrm{~b}$ \\
\hline & & Mean & $6.32 b$ & $5.16 a$ & $7.28 c$ & 6.25 \\
\hline & 2016 & PP & 5.91 a $b$ & 2.97 a $a$ & 5.48 a $b$ & $4.79 \mathrm{a}$ \\
\hline & & SL & $7.39 c b$ & $3.79 \mathrm{~b} \mathrm{a}$ & $6.71 \mathrm{~b} b$ & $5.96 \mathrm{~b}$ \\
\hline & & GL & $6.32 \mathrm{~b} a b$ & $5.18 \mathrm{c} a$ & $6.82 \mathrm{~b} b$ & $6.11 b$ \\
\hline & & Mean & $6.54 b$ & $3.98 a$ & $6.34 b$ & 5.62 \\
\hline
\end{tabular}

Calculating variance components and significance of the experimental factors for each of the three cultivars separately once more reveals larger values for the locations compared to years in all cultivars, except for flowering in all cultivars and seed weight for the cultivars SL and GL (TABLE 2.6). The effect of the population within cultivar (generations 0 , and 5 and 10 from the provenances $R, S$, and $T$ ) is significant across all traits for PP, but not for SL and GL. Populations within SL show significant effects for straw and total yield and for flowering. Populations within GL did not show significant variation, except in ripening. Heritability values for populations are highest within PP, except in ripening, compared to the other cultivars, and range between 51.1 and 99.4 in ripening and seed weight, respectively. Within SL and GL, the highest heritability values were calculated for flowering in SL with 85.1 and for ripening in GL with 76.2 .

Mean values across both years of all populations of Pisarecka Perla and all traits are shown in TABLE 2.7 for each test location. Significant differences between populations were identified for seed and straw yield at Schönhagen. For the harvest index and ripening score significant variation between populations are observed at Reinshof and Tangsehl and for seed weight and flowering time at all test locations. 
TABLE 2.6 Variance components from ANOVA for the main effects year, location, and population, the replication (error variance for year and location), and the residual variance (error variance for selection) with their significance in the F-test ${ }^{\text {a) }}$ for each cultivar (PP, SL, GL) separately, and the heritability values $\left(\mathrm{h}^{2}\right)$ calculated for selection within cultivar for each trait.

\begin{tabular}{|c|c|c|c|c|c|c|c|c|}
\hline \multicolumn{9}{|l|}{ Pisarecka Perla } \\
\hline Source & DF $^{\mathrm{b})}$ & KY & SY & TY & HI & SW & FTsum & $\mathbf{R P}$ \\
\hline$Y$ & 1 & $2119 * *$ & $5453^{* *}$ & $14378 * *$ & $0.966 *$ & 0.015 & $9.801^{* *}$ & $0.156^{* *}$ \\
\hline L & 2 & $6851 * *$ & $31658 * *$ & $67950 * *$ & $12.18 * *$ & $6.046 * *$ & $6.806 * *$ & $1.500 * *$ \\
\hline LY & 2 & $490.7^{* *}$ & $1665^{* *}$ & $3559 * *$ & $9.632 * *$ & $1.659 *$ & $4.234 * *$ & $0.246 * *$ \\
\hline$R: L Y$ & 18 & $166.1^{* *}$ & $649.2 * *$ & $1468 * *$ & $1.406 * *$ & $1.133 * *$ & $0.735^{* *}$ & $0.083 * *$ \\
\hline $\mathrm{P}$ & 5 & $25.14 * *$ & $72.65^{* *}$ & $97.18 * *$ & $1.606 * *$ & $20.47^{* *}$ & $2.507^{* *}$ & $0.010^{+}$ \\
\hline PL & 10 & 21.82 & 23.22 & 36.94 & $0^{c)}$ & 0.051 & $0.571 * *$ & 0.016 \\
\hline PY & 5 & $32.10^{+}$ & 22.74 & $102.2^{+}$ & 0.253 & 0.122 & $0.752 * *$ & 0.005 \\
\hline PLY & 10 & 31.27 & 96.35 & $316.0^{*}$ & 0 & 0.176 & 0 & 0 \\
\hline RPC:LY & 90 & 302.4 & 395.4 & 962.1 & 6.902 & 3.063 & 0.988 & 0.235 \\
\hline \multicolumn{2}{|c|}{ Heritability $(P)$} & 66.6 & 81.5 & 70.8 & 84.81 & 99.38 & 98.38 & 51.12 \\
\hline \multicolumn{9}{|c|}{ Schwarze Linse } \\
\hline Source & DF & KY & SY & TY & HI & SW & FTsum & RP \\
\hline Y & 1 & $3380 * *$ & $7213^{* *}$ & $20493 * *$ & $0.774^{+}$ & $0.235^{*}$ & $10.23 * *$ & $0.359 * *$ \\
\hline $\mathrm{L}$ & 2 & $8479 * *$ & $29347 * *$ & $69396 * *$ & $3.864 * *$ & $0.199^{+}$ & $8.523 * *$ & $1.920 * *$ \\
\hline LY & 2 & $774.4^{* *}$ & $1622 * *$ & $4689 * *$ & 0 & $0.628^{*}$ & $7.357^{* *}$ & $1.268 * *$ \\
\hline$R: L Y$ & 18 & $301.1 * *$ & $396.1 * *$ & $1153^{* *}$ & $3.044 * *$ & $0.661 * *$ & $0.875^{* *}$ & $0.18^{* *}$ \\
\hline $\mathrm{P}$ & 6 & 7.185 & $26.13^{*}$ & $68.08^{*}$ & 0 & 0.022 & $0.232 * *$ & 0 \\
\hline PL & 12 & 0 & $39.35^{+}$ & 0 & 0 & 0 & $0.305^{* *}$ & 0 \\
\hline PY & 6 & 0 & 0 & 0 & 0 & 0.017 & 0 & 0 \\
\hline PLY & 12 & 0 & 0 & 0 & 0 & 0 & 0 & 0 \\
\hline RPC:LY & 108 & 443.7 & 470.1 & 1380 & 6.793 & 0.67 & 0.972 & 0.293 \\
\hline Heritability $(P)$ & & 27.99 & 57.15 & 54.21 & 0 & 44.45 & 85.12 & 0 \\
\hline \multicolumn{9}{|c|}{ Gestreifte Linse } \\
\hline Source & DF & KY & SY & TY & HI & sw & FTsum & RP \\
\hline Y & 1 & $1692^{* *}$ & $2673^{* *}$ & $8692 * *$ & $3.595 * *$ & 0.035 & $55.35 * *$ & $0.127^{* *}$ \\
\hline $\mathrm{L}$ & 2 & $12016 *$ & $35552 *$ & 88979* & $26.12^{+}$ & 0 & 3.474 & $1.034^{*}$ \\
\hline LY & 2 & $1020 * *$ & $1511^{* *}$ & $5207^{* *}$ & $3.751^{*}$ & $4.327^{* *}$ & $7.047^{* *}$ & 0.043 \\
\hline$R: L Y$ & 18 & $363.0 * *$ & 261.8 & $1036 * *$ & $2.608^{*}$ & $0.363 * *$ & $1.628 * *$ & $0.178 * *$ \\
\hline$P$ & 6 & 9.177 & 0 & 0 & 0.534 & 0.029 & 0.008 & $0.012^{+}$ \\
\hline PL & 12 & $81.65^{* *}$ & 0 & 0 & 0.94 & 0 & 0.063 & 0 \\
\hline PY & 6 & 0 & 0 & 18.91 & 0 & 0.019 & 0 & 0 \\
\hline PLY & 12 & 0 & 0 & 0 & 0 & $0.077^{+}$ & 0 & 0.003 \\
\hline RPC:LY & 108 & 484 & 4997 & 5949 & 16.69 & 0.428 & 0.909 & 0.172 \\
\hline Heritability $(\mathrm{P})$ & & 40.26 & 0 & 0 & 60.55 & 51.56 & 19.84 & 76.19 \\
\hline
\end{tabular}


TABLE 2.7 Mean values of populations of Pisarecka Perla in generation 0,5 , and 10 under natural selection at three locations $(R, S, T)$ identical to the test locations.

\begin{tabular}{|c|c|c|c|c|c|}
\hline \multirow[b]{2}{*}{ Trait } & \multirow[b]{2}{*}{ Population } & \multicolumn{3}{|c|}{ Test location } & \multirow[b]{2}{*}{ Mean } \\
\hline & & Reinshof & Schönhagen & Tangsehl & \\
\hline \multirow{7}{*}{$\begin{array}{l}\text { Seed yield } \\
{\left[\mathrm{gm}^{-2}\right]}\end{array}$} & PP_0 & 229.7 & $94.8 \mathrm{a}^{\mathrm{a})}$ & 60.7 & $128.4 \mathrm{ab}$ \\
\hline & PP_R_5 & 219.0 & $103.3 \mathrm{ab}$ & 63.7 & $128.7 \mathrm{ab}$ \\
\hline & PP_S_5 $5^{b)}$ & - & - & - & 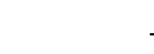 \\
\hline & PP_T_5 & 228.8 & $98.5 \mathrm{a}$ & 61.8 & $129.7 \mathrm{ab}$ \\
\hline & PP_R_10 & 203.6 & $102.4 a b$ & 58.9 & 121.6 \\
\hline & PP_S_10 & 228.8 & $106.7 \mathrm{ab}$ & 65.1 & $133.5 \mathrm{ab}$ \\
\hline & PP_T_10 & 227.7 & $125.8 \mathrm{~b}$ & 66.8 & $140.1 \mathrm{~b}$ \\
\hline \multirow{7}{*}{$\begin{array}{l}\text { Straw yield } \\
{\left[\mathrm{gm}^{-2}\right]}\end{array}$} & PP_0 & 417.1 & $162.3 \mathrm{ab}$ & 95.0 & $224.8 \mathrm{ab}$ \\
\hline & PP_R_5 & 438.0 & $175.7 \mathrm{abc}$ & 103.7 & $239.1 \mathrm{ab}$ \\
\hline & PP_S_5 & - & - & - & 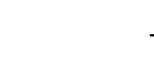 \\
\hline & PP_T_5 & 426.6 & $156.2 \mathrm{a}$ & 86.8 & $223.2 \mathrm{a}$ \\
\hline & PP_R_10 & 451.1 & $176.3 \mathrm{abc}$ & 97.9 & $241.8 b$ \\
\hline & PP_S_10 & 453.4 & 183.6 bc & 102.7 & $246.6 \mathrm{~b}$ \\
\hline & PP_T_10 & 431.6 & $191.1 \mathrm{c}$ & 90.8 & $237.8 \mathrm{ab}$ \\
\hline \multirow{7}{*}{$\begin{array}{l}\text { Total yield } \\
{\left[\mathrm{gm}^{-2}\right]}\end{array}$} & PP_0 & 646.8 & $257.0 \mathrm{a}$ & 155.7 & $353.2 \mathrm{ab}$ \\
\hline & PP_R_5 & 656.9 & $279.0 \mathrm{ab}$ & 167.4 & $367.8 \mathrm{ab}$ \\
\hline & PP_S_5 & - & - & - & 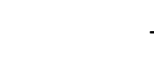 \\
\hline & PP_T_5 & 655.4 & $254.7 \mathrm{a}$ & 148.6 & 352.9 a \\
\hline & PP_R_10 & 654.6 & $278.7 a b$ & 156.8 & $363.4 \mathrm{ab}$ \\
\hline & PP_S_10 & 682.1 & $290.3 a b$ & 167.8 & $380.1 \mathrm{~b}$ \\
\hline & PP_T_10 & 659.3 & 316.9 b & 157.6 & $377.9 \mathrm{ab}$ \\
\hline \multirow{7}{*}{$\begin{array}{l}\text { Harvest } \\
\text { index }\end{array}$} & PP_0 & $35.27 b$ & 37.85 & $40.75 a b$ & $37.96 a b c$ \\
\hline & PP_R_5 & $33.21 \mathrm{ab}$ & 38.03 & $39.21 \mathrm{ab}$ & $36.82 \mathrm{ab}$ \\
\hline & PP_S_5 & - & - & - & 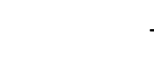 \\
\hline & PP_T_5 & $34.64 a b$ & 39.60 & $41.96 \mathrm{ab}$ & $38.73 b c$ \\
\hline & PP_R_10 & 30.77 a & 37.66 & $38.56 \mathrm{a}$ & 35.66 \\
\hline & PP_S_10 & $33.37 \mathrm{ab}$ & 37.05 & $39.24 a b$ & $36.55 \mathrm{ab}$ \\
\hline & PP_T_10 & $34.13 a b$ & 40.77 & $42.79 \mathrm{~b}$ & 39.23 \\
\hline \multirow{7}{*}{$\begin{array}{l}\text { Seed } \\
\text { weight } \\
{[\mathrm{mg}]}\end{array}$} & PP_0 & $54.73 \mathrm{~b}$ & $60.82 c$ & $59.25 \mathrm{bc}$ & $58.27 c$ \\
\hline & PP_R_5 & 57.81 bc & $61.44 \mathrm{c}$ & 61.82 c & $60.36 \mathrm{~d}$ \\
\hline & PP_S_5 & - & - & - & 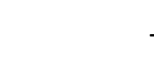 \\
\hline & PP_T_5 & $53.15 \mathrm{~b}$ & $56.90 \mathrm{~b}$ & $57.75 b$ & $55.93 \mathrm{~b}$ \\
\hline & PP_R_10 & $59.96 \mathrm{c}$ & $62.97 \mathrm{c}$ & $64.78 \mathrm{~d}$ & $62.57 \mathrm{e}$ \\
\hline & PP_S_10 & $56.01 \mathrm{~b}$ & $60.66 c$ & $60.76 \mathrm{c}$ & $59.14 \mathrm{~cd}$ \\
\hline & PP_T_10 & $46.87 \mathrm{a}$ & $50.39 \mathrm{a}$ & $51.34 \mathrm{a}$ & $49.53 \mathrm{a}$ \\
\hline
\end{tabular}

Table continues on the following page. 
Table 2.7 continued.

\begin{tabular}{llcccr}
\hline \hline Flowering & PP_0 & $24.44 \mathrm{c}$ & $24.94 \mathrm{~b}$ & $28.19 \mathrm{ab}$ & $25.86 \mathrm{c}$ \\
score sum & PP_R_5 & $21.44 \mathrm{ab}$ & $22.81 \mathrm{a}$ & $27.75 \mathrm{a}$ & $24.00 \mathrm{ab}$ \\
& PP_S_5 & - & - & - & - \\
& PP_T_5 & $25.56 \mathrm{c}$ & $27.06 \mathrm{c}$ & $29.56 \mathrm{c}$ & $27.39 \mathrm{~d}$ \\
& PP_R_10 & $20.00 \mathrm{a}$ & $22.31 \mathrm{a}$ & $27.38 \mathrm{a}$ & $23.23 \mathrm{a}$ \\
& PP_S_10 & $22.44 \mathrm{~b}$ & $23.00 \mathrm{a}$ & $27.50 \mathrm{a}$ & $24.31 \mathrm{~b}$ \\
& PP_T_10 & $25.13 \mathrm{c}$ & $25.38 \mathrm{bc}$ & $28.63 \mathrm{~b}$ & $26.38 \mathrm{c}$ \\
\hline \hline Ripening & PP_0 & $6.88 \mathrm{~b}$ & 4.44 & $6.44 \mathrm{ab}$ & $5.92 \mathrm{ab}$ \\
score & PP_R_5 & $7.06 \mathrm{~b}$ & 4.50 & $6.31 \mathrm{ab}$ & $5.96 \mathrm{ab}$ \\
& PP_S_5 & - & - & - & - \\
& PP_T_5 & $6.63 \mathrm{ab}$ & 4.75 & $6.75 \mathrm{~b}$ & $6.04 \mathrm{~b}$ \\
& PP_R_10 & $6.25 \mathrm{a}$ & 4.44 & $6.25 \mathrm{a}$ & $5.65 \mathrm{a}$ \\
& PP_S_10 & $6.69 \mathrm{ab}$ & 4.38 & $6.25 \mathrm{a}$ & $5.77 \mathrm{ab}$ \\
& PP_T_10 & $6.75 \mathrm{ab}$ & 4.25 & $6.69 \mathrm{ab}$ & $5.90 \mathrm{ab}$ \\
\hline a) Mean values followed column-wise by the same letter are not significantly different in Tukey's-HSD test at P=0.05. \\
b) Population in generation 5 from Schönhagen is not available.
\end{tabular}

To reveal site specific population effects, analysis of variance and mean comparisons were done with the populations in the $10^{\text {th }}$ generation of natural selection at three farms to compare their performance at the three same farms during two years (TABLE 2.8, TABLE 2.9).

In cultivar SL, significant variation between populations was found for seed weight, leaf size and ripening at Reinshof (TABLE 2.8). At Reinshof the population selected at Tangsehl (SL_T_10) expressed a significantly higher seed weight with $23.85 \mathrm{mg}$ compared to 22.87 to $23.02 \mathrm{mg}$ in the other cultivars (TABLE 2.9). In the F-test in the ANOVA leaf size was significantly influenced by the population at $P=0.1$. Leaf size means for the Reinshof population (SL_R_10) was lower with $9.18 \mathrm{~cm}^{2}$ compared the other two populations SL_S_10 and SL_T_10 with 9.82 and $9.81 \mathrm{~cm}^{2}$, respectively. Means of leaf size were not significantly different at $P=0.1$. Ripening at Reinshof was earliest for SL_S_10, followed by SL_T_10 and SL_R_10, however mean comparisons were not significant. At Schönhagen, straw yield was significantly higher for SL_S_10 with $145.36 \mathrm{gm}^{-2}$ compared to SL_T_10 with $125.09 \mathrm{gm}^{-2}$; SL_R_10 yielded 135 . None of the other traits revealed significant variation at Schönhagen and none of the traits assessed in Tangsehl showed significant variation in the analysis.

Populations of cultivar GL varied significantly for total yield between populations tested at Reinshof. Total yield of GL_R_10 was significantly higher compared to GL_S_10. None of the traits assessed at the two other locations Schönhagen and Tangsehl gave significant results in this analysis.

Populations of cultivar PP showed significant variation for all traits in at least one of the three locations (TABLE 2.8, TABLE 2.9). Significant variation for seed and total yield could be observed in Schönhagen (at $\mathrm{P}=0.05$ ) and for either seed or straw yield at Reinshof and Tangsehl (at $\mathrm{P}=0.1$ ), respectively (TABLE 2.8). Harvest index, seed weight and flowering varied significantly at all locations between populations. Means for ripening varied significantly (at $\mathrm{P}=0.1$ ) between populations at Reinshof and Tangsehl. Additionally, hypocotyl color and leaf size was assessed at Reinshof and Tangsehl or Reinshof only and reveals significant variation between populations. 
TABLE 2.8 Variance components from ANOVA for the cultivar Pisarecka Perla of the main effects year, population, year-population interaction (YXP), replication (error variance for year), and the residual variance (error variance for population) and their significance levels in the F-test ${ }^{\mathrm{a}}$, , calculated separately for each test location from a data-set including the three populations in generation 10 under natural selection from the three locations.

\begin{tabular}{|c|c|c|c|c|c|c|c|}
\hline Trait & Test location & $\begin{array}{c}\text { Year } \\
(\mathrm{DF}=1)\end{array}$ & $\begin{array}{c}\text { Population } \\
(\mathrm{DF}=2)\end{array}$ & $\begin{array}{c}\mathbf{Y x P} \\
(\mathrm{DF}=2)\end{array}$ & $\begin{array}{c}\text { Replication } \\
(\mathrm{DF}=6)\end{array}$ & $\begin{array}{c}\text { Residual } \\
(\mathrm{DF}=12)\end{array}$ & $h^{2}$ \\
\hline Seed & Reinshof & $3762 * *$ & $144.2^{+}$ & 93.47 & $0^{b)}$ & 468.2 & 71.14 \\
\hline \multirow{2}{*}{ yield } & Schönhagen & $5251 * *$ & $130.9 *$ & 0 & $442.6 * *$ & 196.9 & 84.19 \\
\hline & Tangsehl & $282.4^{+}$ & 6.993 & 0 & $367.8^{* *}$ & 83.66 & 40.07 \\
\hline Straw & Reinshof & $3963 * *$ & 1.970 & 270.9 & 149.62 & 1126 & 1.38 \\
\hline \multirow[t]{2}{*}{ yield } & Schönhagen & $18094 * *$ & 29.31 & 0 & $1069 * *$ & 202.2 & 53.70 \\
\hline & Tangsehl & $1240^{+}$ & $25.61^{+}$ & 13.25 & $1065^{* *}$ & 85.58 & 70.54 \\
\hline Total & Reinshof & $15508^{* *}$ & 0 & 916.4 & 360.2 & 2123 & 0 \\
\hline \multirow[t]{2}{*}{ yield } & Schönhagen & $42856 * *$ & $305.6^{*}$ & 0 & $2900 * *$ & 623.55 & 79.68 \\
\hline & Tangsehl & $2720^{+}$ & 6.164 & 0 & $1394 * *$ & 253.6 & 16.28 \\
\hline Harvest & Reinshof & $9.173^{*}$ & $2.269 *$ & 0 & 0 & 5.912 & 76.22 \\
\hline \multirow[t]{2}{*}{ index } & Schönhagen & $5.791^{* *}$ & $3.231^{*}$ & 0.209 & 0 & 6.022 & 81.10 \\
\hline & Tangsehl & $4.763^{*}$ & $4.502 * *$ & 0 & 0.983 & 5.243 & 87.29 \\
\hline Seed & Reinshof & $0.984 *$ & $44.95 * *$ & $1.532 *$ & 0.085 & 1.319 & 99.63 \\
\hline \multirow[t]{2}{*}{ weight } & Schönhagen & 1.617 & $44.69 * *$ & $0.992 *$ & $2.634^{* *}$ & 1.251 & 99.65 \\
\hline & Tangsehl & 0 & $47.26^{* *}$ & 0.123 & $2.415^{*}$ & 2.463 & 99.35 \\
\hline \multirow{3}{*}{$\begin{array}{l}\text { Flowering } \\
\text { score sum }\end{array}$} & Reinshof & $9.737 * *$ & $6.469 * *$ & 0.298 & $0.531^{+}$ & 0.819 & 98.44 \\
\hline & Schönhagen & $31.59 * *$ & $2.364 * *$ & 0.348 & 0 & 1.743 & 91.56 \\
\hline & Tangsehl & $1.34^{+}$ & $0.420 * *$ & $0.34^{*}$ & $1.236^{* *}$ & 0.431 & 88.64 \\
\hline \multirow{3}{*}{$\begin{array}{l}\text { Ripening } \\
\text { score }\end{array}$} & Reinshof & 0 & $0.050^{+}$ & 0 & 0 & 0.191 & 67.84 \\
\hline & Schönhagen & $0.875^{*}$ & 0 & 0 & 0.125 & 0.469 & 0 \\
\hline & Tangsehl & 0.013 & $0.045^{+}$ & $0.090^{+}$ & $0.069^{+}$ & 0.149 & 70.75 \\
\hline \multirow{2}{*}{$\begin{array}{l}\text { Hypocotyl } \\
\text { color }\end{array}$} & Reinshof & 0 & $639.9 * *$ & 0 & 0 & 14.51 & 99.72 \\
\hline & Tangsehl & $20.62^{+}$ & $382.4^{* *}$ & 0 & 7.829 & 26.82 & 99.13 \\
\hline Leaf size & Reinshof & $11.59 * *$ & $0.663^{*}$ & 0 & 0.185 & 1.027 & 83.76 \\
\hline
\end{tabular}

Across test locations, significantly higher seed yield was observed for PP_T_10 compared to PP_R_10, as well as at location Schönhagen (TABLE 2.9). Straw yield and total yield was as well highest for PP_T_10 in Schönhagen, but not for the other locations. The harvest index is highest and significantly different from PP_R_10 for PP_T_10 at all locations. All seed weight mean comparisons are significant at all locations. Flowering score sums are significantly higher for PP_T_10 and at Reinshof and Tangsehl ripening scores are higher compared to PP_R_10, meaning earlier flowering and ripening. 
TABLE 2.9 Mean values for populations of Pisarecka Perla across two years at the three location for the population in generation 0 (PP_0) and in generation 10 under natural selection at the locations (R_10, S_10, T_10).

\begin{tabular}{llcccc}
\hline & & \multicolumn{3}{c}{ Test location } & \\
\cline { 2 - 5 } Trait & Population & Reinshof & Schönhagen & Tangsehl & Mean \\
yield [gm ${ }^{-2}$ ] & R_10 & $203.57 \mathrm{a}^{\text {a) }}$ & $102.36 \mathrm{a}$ & 58.85 & $121.59 \mathrm{a}$ \\
& S_10 & $228.77 \mathrm{~b}$ & $106.72 \mathrm{a}$ & 65.05 & $133.51 \mathrm{ab}$ \\
& T_10 & $227.66 \mathrm{~b}$ & $125.81 \mathrm{~b}$ & 66.8 & $140.09 \mathrm{~b}$ \\
\hline Straw & R_10 & 451.06 & 176.29 & $97.91 \mathrm{ab}$ & 241.75 \\
yield [gm ${ }^{-2}$ ] & S_10 & 453.38 & 183.57 & $102.72 \mathrm{~b}$ & 246.56 \\
& T_10 & 431.63 & 191.06 & $90.75 \mathrm{a}$ & 237.81 \\
\hline Total & R_10 & 654.64 & $278.67 \mathrm{a}$ & 156.77 & 363.36 \\
yield [gm ${ }^{-2}$ ] & S_10 & 682.13 & $290.33 \mathrm{ab}$ & 167.8 & 380.09 \\
& T_10 & 659.30 & $316.89 \mathrm{~b}$ & 157.55 & 377.91 \\
\hline Harvest & R_10 & $30.77 \mathrm{a}$ & $37.66 \mathrm{ab}$ & $38.56 \mathrm{a}$ & $35.66 \mathrm{a}$ \\
index & S_10 & $33.37 \mathrm{ab}$ & $37.05 \mathrm{a}$ & $39.24 \mathrm{ab}$ & $36.55 \mathrm{ab}$ \\
& T_10 & $34.13 \mathrm{~b}$ & $40.77 \mathrm{~b}$ & $42.79 \mathrm{~b}$ & $39.23 \mathrm{~b}$ \\
\hline Seed & R_10 & $59.96 \mathrm{c}$ & $62.97 \mathrm{c}$ & $64.78 \mathrm{c}$ & $62.57 \mathrm{c}$ \\
weight [mg] & S_10 & $56.01 \mathrm{~b}$ & $60.66 \mathrm{~b}$ & $60.76 \mathrm{~b}$ & $59.14 \mathrm{~b}$ \\
& T_10 & $46.87 \mathrm{a}$ & $50.39 \mathrm{a}$ & $51.34 \mathrm{a}$ & $49.53 \mathrm{a}$ \\
\hline Flowering & R_10 & $20.00 \mathrm{a}$ & $22.31 \mathrm{a}$ & $27.38 \mathrm{a}$ & $23.23 \mathrm{a}$ \\
score sum & S_10 & $22.44 \mathrm{~b}$ & $23.00 \mathrm{ab}$ & $27.50 \mathrm{ab}$ & $24.31 \mathrm{~b}$ \\
& T_10 & $25.13 \mathrm{c}$ & $25.38 \mathrm{~b}$ & $28.63 \mathrm{~b}$ & $26.38 \mathrm{c}$ \\
\hline Ripening & R_10 & $6.25 \mathrm{a}$ & 4.44 & $6.25 \mathrm{a}$ & 5.65 \\
scores & S_10 & $6.69 \mathrm{ab}$ & 4.38 & $6.25 \mathrm{a}$ & 5.77 \\
& T_10 & $6.75 \mathrm{~b}$ & 4.25 & $6.69 \mathrm{~b}$ & 5.90 \\
\hline a) Mean values followed by the same letter column-wise are not significantly different in & Tukey's-HSD test; & \\
\multicolumn{1}{c}{ small italic letters denote comparisons at P=0.1, non-italic letters denote comparisons at P=0.05. } &
\end{tabular}

Generations of Schwarze Linse showed significant variation across provenances for flowering with significantly earlier flowering of populations in generation 10 compared to generation 0 (data not shown). For provenance Reinshof and Tangsehl, generation 5 is already significantly earlier flowering compared to generation 0 , whereas generation 5 from Schönhagen does not differ significantly from generation 0 (data not shown). Seed, straw and total yield is significantly higher for SL_S_10 compared to SL_S_5, but both populations do not yield significantly different compared to SL_0. The same situation was observed on the lower significance level at $\mathrm{P}=0.1$ and exclusively for straw yield in the population SL_R_10, being significantly higher compared to SL_R_5, but not significantly different compared to SL_0. None of the traits showed significant variation when comparing generations from Tangsehl (data not shown). Comparisons of generations within provenances for populations of the cultivar Gestreifte Linse were not significant (data not shown).

To see the effect of time under natural selection, populations in generation 0,5 , and 10 were compared separately for each selection site across all test locations (TABELLE 2.10-2.11). For cultivar Pisarecka Perla, populations in different generations under natural selection varied for most traits significantly (TABLE 2.10). The mean comparisons are shown in TABLE 2.11. Overall, a trend for increasing yield from generation 0 to 
5 and 10 was observed together with a decreasing harvest index and later ripening. Seed weight is significantly increasing at Reinshof together with a delayed flowering, whereas the selection at Tangsehl reduced seed weight significantly from generation 0 to 5 and again to generation 10 . Flowering of generation 10 from Tangsehl did not differ significantly from generation 0.

TABLE 2.10 Variance components from ANOVA for Pisarecka Perla for the main effects of year, location, generation, replication (error variance for year and location), and residual (error variance for generation) with their significance in the F-test ${ }^{a}$, calculated separately for the provenances $(R, S, T)$ comparing generations 0,5 , and 10 .

\begin{tabular}{llcccccc}
\hline Trait & $\begin{array}{l}\text { Prov- } \\
\text { enance }\end{array}$ & $\begin{array}{c}\text { Year } \\
(\mathrm{DF}=1)\end{array}$ & $\begin{array}{c}\text { Location } \\
(\mathrm{DF}=2)\end{array}$ & $\begin{array}{c}\text { Generation } \\
(\mathrm{DF}=1 ; 2)^{\mathrm{b})}\end{array}$ & $\begin{array}{c}\text { Replication } \\
(\mathrm{DF}=18)\end{array}$ & $\begin{array}{c}\text { Residual } \\
(\mathrm{DF}=18 ; 36)^{\mathrm{b})}\end{array}$ & $\mathbf{h}^{\mathbf{2}}$ \\
\hline Seed & PP_R & $1673.47^{* *}$ & $6586.02^{* *}$ & $0^{\mathrm{c})}$ & $117.33^{+}$ & 414.28 & 0 \\
yield & PP_S & $1787.52^{* *}$ & $7558.07^{* *}$ & 5.11 & $248.61^{* *}$ & 193.12 & 38.8 \\
& PP_T & $2181.86^{* *}$ & $7346.66^{* *}$ & $27.19^{+}$ & $119.66^{*}$ & 335.74 & 66.0 \\
\hline Straw & PP_R & $5369.98^{* *}$ & $31279.67^{* *}$ & $66.51^{*}$ & $510.78^{* *}$ & 408.92 & 79.6 \\
yield & PP_S & $4858.85^{* *}$ & $31131.64^{* *}$ & $226.63^{* *}$ & $733.05^{* *}$ & 257.26 & 95.5 \\
& PP_T & $5099.05^{* *}$ & $30426.77^{* *}$ & $42.47^{+}$ & $586.36^{* *}$ & 521.79 & 66.1 \\
\hline Total & PP_R & $13056.51^{* *}$ & $66579.80^{* *}$ & 4.37 & $1091.34^{* *}$ & 1240.82 & 7.8 \\
yield & PP_S & $12582.20^{* *}$ & $69424.06^{* *}$ & $334.23^{* *}$ & $1481.08^{* *}$ & 667.20 & 92.3 \\
& PP_T & $13967.72^{* *}$ & $67690.78^{* *}$ & $161.85^{*}$ & $1291.91^{* *}$ & 1066.27 & 78.5 \\
\hline Harvest & PP_R & $2.63^{*}$ & $10.41^{* *}$ & $0.92^{*}$ & $2.56^{+}$ & 9.39 & 70.3 \\
index & PP_S & 0.62 & $7.19^{* *}$ & $0.78^{*}$ & $4.78^{*}$ & 4.73 & 79.9 \\
& PP_T & $0.91^{*}$ & $12.85^{* *}$ & 0.08 & 0.49 & 7.3 & 19.9 \\
\hline Seed & PP_R & $0.42^{+}$ & $6.01^{* *}$ & $4.44^{* *}$ & 0.81 & 4.63 & 95.8 \\
weight & PP_S & 0 & $8.00^{* *}$ & 0.16 & 1.13 & 5.26 & 42.7 \\
& PP_T & 0.07 & $6.45^{* *}$ & $20.28^{* *}$ & 0.79 & 4.21 & 99.1 \\
\hline Flowering & PP_R & $13.67^{* *}$ & $9.04^{* *}$ & $1.78^{* *}$ & $1.04^{* *}$ & 0.97 & 97.8 \\
score sum & PP_S & $9.64^{* *}$ & $5.62^{* *}$ & $1.13^{* *}$ & $0.69^{+}$ & 1.32 & 95.4 \\
& PP_T & $5.83^{* *}$ & $3.78^{* *}$ & $0.57^{* *}$ & $0.87^{* *}$ & 1.05 & 92.9 \\
\hline Ripening & PP_R & $0.09^{*}$ & $1.45^{* *}$ & $0.03^{*}$ & $0.11^{* *}$ & 0.18 & 73.7 \\
scores & PP_S & $0.08^{*}$ & $1.58^{* *}$ & 0 & 0 & 0.45 & 0 \\
& PP_T & $0.25^{* *}$ & $1.60^{* *}$ & 0 & $0.14^{* *}$ & 0.20 & 0 \\
\hline
\end{tabular}

a) Significance levels are denoted with $* *,{ }^{*},{ }^{+}$for $P$-values $=0.01,0.05,0.1$, respectively.

b) Degrees of freedom (DF) differ for generation and the residual due to the missing population PP_S_5.

c) Negative estimates. 
TABLE 2.11 Mean values of populations from Pisarecka Perla in generation 0,5 , and 10 under natural selection at three different locations $(R, S, T)$.

\begin{tabular}{|c|c|c|c|c|c|}
\hline \multirow[b]{2}{*}{ Trait } & \multirow[b]{2}{*}{ Generation } & \multicolumn{3}{|c|}{ Selection site } & \multirow[b]{2}{*}{ Mean ${ }^{\text {a) }}$} \\
\hline & & $\mathbf{R}$ & $S$ & $\mathbf{T}$ & \\
\hline Seed & Gen. 0 & 128.39 & 128.39 & $128.39 a^{b)}$ & 128.39 \\
\hline \multirow[t]{2}{*}{ yield $\left[\mathrm{gm}^{-2}\right]$} & Gen. 5 & 128.66 & - c) & $129.68 a b$ & 129.17 \\
\hline & Gen. 10 & 121.60 & 133.52 & $140.09 b$ & 131.74 \\
\hline Straw & Gen. 0 & $224.77 \mathrm{a}$ & $224.77 \mathrm{a}$ & $224.77 a b$ & 224.77 \\
\hline \multirow[t]{2}{*}{ yield $\left[\mathrm{gm}^{-2}\right]$} & Gen. 5 & $239.12 \mathrm{~b}$ & - & $223.23 a$ & 231.18 \\
\hline & Gen. 10 & $241.75 b$ & $246.56 b$ & $237.81 b$ & 242.04 \\
\hline Total & Gen. 0 & 353.17 & $353.17 \mathrm{a}$ & $353.17 \mathrm{a}$ & 353.17 \\
\hline \multirow{2}{*}{ yield $\left[\mathrm{gm}^{-2}\right]$} & Gen. 5 & 367.77 & - & 352.90 a & 360.34 \\
\hline & Gen. 10 & 363.36 & $380.08 \mathrm{~b}$ & $377.91 \mathrm{~b}$ & 373.78 \\
\hline Harvest & Gen. 0 & $37.96 \mathrm{~b}$ & $37.96 \mathrm{~b}$ & 37.96 & 37.96 \\
\hline \multirow[t]{2}{*}{ Index } & Gen. 5 & $36.81 a b$ & - & 38.73 & 37.77 \\
\hline & Gen. 10 & $35.66 \mathrm{a}$ & $36.56 \mathrm{a}$ & 39.23 & 37.15 \\
\hline Seed & Gen. 0 & $58.27 \mathrm{a}$ & 58.27 & $58.27 c$ & 58.27 \\
\hline \multirow[t]{2}{*}{ weight [mg] } & Gen. 5 & $60.35 b$ & - & $55.93 b$ & 58.14 \\
\hline & Gen. 10 & $62.57 c$ & 59.14 & $49.53 \mathrm{a}$ & 57.08 \\
\hline \multirow[t]{3}{*}{ Ftsum } & Gen. 0 & $25.85 c$ & $25.85 b$ & $25.85 a$ & 25.85 \\
\hline & Gen. 5 & $24.00 \mathrm{~b}$ & - & $27.40 \mathrm{~b}$ & 25.70 \\
\hline & Gen. 10 & $23.23 a$ & $24.31 \mathrm{a}$ & $26.38 \mathrm{a}$ & 24.64 \\
\hline Ripening & Gen. 0 & $5.92 a b$ & 5.92 & 5.92 & 5.92 \\
\hline \multirow{2}{*}{ scores } & Gen. 5 & $5.96 \mathrm{~b}$ & - & 6.04 & 6.00 \\
\hline & Gen. 10 & $5.65 \mathrm{a}$ & 5.77 & 5.90 & 5.77 \\
\hline
\end{tabular}

TABLE 2.12 Proportion [\%] of seedlings with red pigmentation on the hypocotyl in populations of Pisarecka Perla in generation 0,5 , and 10 from the three farms $(R, S, T)$ observed and counted during field testing at the same three locations.

\begin{tabular}{lcccr}
\hline Population & Reinshof & Schönhagen & Tangsehl & Mean \\
\hline PP_0 & 10.4 & 3.4 & 6.6 & 6.8 \\
PP_R_5 & 0.4 & 0.5 & 10.6 & 3.8 \\
PP_T_5 & 22.6 & 20.3 & 19.7 & 20.8 \\
PP_R_10 & 0.6 & 0.3 & 3.5 & 1.5 \\
PP_S_10 & 3.3 & 2.6 & 4.8 & 3.6 \\
PP_T_10 & 45.8 & 34.2 & 38.1 & 39.4 \\
\hline
\end{tabular}


Different proportions of seedlings with red pigmentation on the hypocotyl were observed in populations of Pisarecka Perla (TABLE 2.12). These proportions differ between test locations. The highest proportion of red seedlings were observed in generation 10 under selection in Tangsehl followed by generation 5 from the same selection site. Very low proportions were found in populations under selection at Reinshof. Populations from Schönhagen carried relatively low proportions of red pigmented seedlings, depending on the test location with similar or lower proportions compared to the initial population (PP_0).

For most traits, no effect of site-specific selection or differences between generations of selection was observed on a statistically significant level in Schwarze Linse and Gestreifte Linse (data not shown). On a low significance level $(\mathrm{P}=10 \%)$, flowering was earlier in generation 5 and 10 under natural selection in Tangsehl compared to the initial population at Reinshof in Gestreifte Linse (data not shown). This effect was statistically highly significant in Schwarze Linse for generation 5 and 10 from Tansehl and for generation 10 from Schönhagen compared to the initial population in Schönhagen (data not shown). 


\subsection{Discussion}

A strong and highly significant variation between years is striking in TABLE 2.4 and TABLE 2.6 especially for yield, but also for the harvest index of Pisarecka Perla and Gestreifte Linse and for seed weight of Schwarze Linse. The season of 2015 was characterized by a relatively dry spring and a warm and not too wet early summer (TABLE 2.2), which was positive for lentil. Especially during grain filling in June and ripening in July, the even distribution of precipitation and absence of heavy rains (FIGURES 8.1-8.3) helped for a good seed development and low virus or fungal disease infestation. The summer in 2016 was less optimal with more precipitation and a high disease pressure, especially at Reinshof and Schönhagen with various virus diseases observed infesting predominantly Schwarze Linse, but also found in Pisarecka Perla and Gestreifte Linse. Consequently, yield was significantly reduced in 2016 compared to 2015 for all cultivars and led to a different ranking of the cultivars (TABLE 2.5). Additionally at Schönhagen, machine sowing was suboptimal in 2016, compared to the highly laborious but successful hand sowing in 2015 , with an uneven distribution of seeds and a poor coverage and weed competition ability. This resulted in huge difficulties in the weed management, a poor crop development, and in the end in a significantly reduced yield of about $70 \%$ in Schönhagen in 2016 compared to the previous year. Also in Tangsehl, a lower plant density was realized in 2016, with on average approximately 66 plants $\mathrm{m}^{-2}$ counted after field emergence, due to difficult soil conditions for the sowing machine.

Comparing the yield potential of the three locations across cultivars, ranking of the locations Reinshof > Schönhagen > Tangsehl is significant in both years. This underlines the significant differences in environmental conditions, presumably primarily for nutrient and water availability, between these consciously selected farms. For Pisarecka Perla and Schwarze Linse in 2016, seed and straw yield are not significantly different between Schönhagen and Tangsehl. In contrast to Pisarecka Perla, where a highly significant variation between populations was found (except for ripening), populations of Schwarze Linse showed significant variation only in straw and total yield and in flowering. For populations of Gestreifte Linse a highly significant population $\times$ location interaction was observed. Thus, effects of the provenance and the temporal development were analyzed separately for Pisarecka Perla from the other two cultivars.

The three populations of Pisarecka Perla in generation ten expressed significant variation for the harvest index at all test sites and for seed and total yield exclusively in Schönhagen (TABLE 2.8). Seed weight and hypocotyl color were affected highly significantly by the provenance of the populations as well as the flowering score sum. The higher mean seed weight of the population selected at Reinshof correlated with a significantly lower seed yield, a lower harvest index, flowering score sum, and ripening score, meaning later flowering and ripening compared to the Tangsehl population (TABLE 2.9). Hence, the population developed at the most 'stress-prone' site (Tangsehl) gave a better seed yield across all locations compared to the population selected at Reinshof. Additionally, at Reinshof the Schönhagen population gave significantly higher seed yield and at Tangsehl significantly higher straw yield compared to the Reinshof population.

Studying the relationship of seed and straw yield, Erskine (1983) calculated positive and significant phenotypic correlations between seed and straw for small seeded $(r=526)$ and large seeded genotypes $(r$ = 339) and observed delayed flowering by eleven days for the highest yielding genotypes compared to the overall mean. Comparing the populations of Pisarecka Perla in the $10^{\text {th }}$ generation, the small seeded population (selected at Tangsehl) flowers significantly earlier and still gives a better seed yield in all 
locations. However, at the most stress-prone location Tangsehl, straw yield is better with the larger seeded populations (selected at Reinshof). It can be argued, due to the challenging conditions and a shorter season length at Tangsehl (TABLE 2.3), natural selection favored small seeded genotypes, because large seeded genotypes produced less seeds due to a lower nutrient and water availability and might have had an additional disadvantage with later flowering. Despite a presumably strong selection pressure at Tangsehl, genetic variability in hypocotyl and seed color is visible. Under more convenient conditions for lentil at Schönhagen, seed weight did not change significantly, thus the full range of genotypes from the initial populations might have been maintained. And at Reinshof, conditions could have been 'too rich' for lentil, favoring large seeded and later flowering genotypes. Consequently, the population selected at Schönhagen did perform relatively well on average across locations due to its genotypic diversity buffering for contrasting conditions. The population selected at Reinshof performed relatively well for straw yield at Tangsehl due to its later flowering at the expense of seed yield. The population selected at Tangsehl performed well when tested at Reinshof in seed yield due to early flowering at the expense of straw yield.

Variation in straw yield between the initial population and generations five and ten of Pisarecka Perla was significant, whereas seed yield was less affected and only significant for Tangsehl populations (TABLE 2.10). The effect of natural selection in populations of Pisarecka Perla is characterized by a significant increase of the seed yield potential in the populations developed at Tangsehl, whereas the selection at Reinshof and Schönhagen led to a significantly higher straw yield and a lower harvest index for generation ten compared to the initial population (TABLE 2.11). Seed weight developed inversely over time at Reinhof (increasing) and Tangsehl (decreasing) and increased not significantly at Schönhagen. Flowering became later at Reinshof and Schönhagen, but earlier for populations developed in Tangsehl. However, the earlier flowering of the Tangsehl populations did not affect ripening significantly. Within the Reinshof populations, the latest generation was later ripening.

In contrast to Pisarecka Perla, Schwarze Linse and Gestreifte Linse were described as less variable already in their description at the genebank and went through bottlenecks during ex situ maintenance (Horneburg 2003b). Consequently, low genetic variability is assumed. Significant effects of site-specific selection could not be observed. However, populations of Schwarze Linse under natural selection in generation 5 and 10 tend to flower earlier compared to the initial population, which was significantly at the test-site Schönhagen across both years for the selection-sites Schönhagen and Tangsehl (Bockelmann 2017, unpublished). Gestreifte Linse tend to flower slightly later in the later generations, which was observed on a low statistical significance level $(P=10 \%)$ at Reinshof for the selection-site Tangsehl. Such a general nonsignificant effect of natural selection was already observed after one year field testing (Becher 2016, unpublished). Studying the "spatio-temporal evolution of earliness" in wheat populations, Goldringer et al. (2006) observed genetic differentiation according to the north-south latitude and concluded that climatic differences between locations led to site-specific evolution of populations after ten generations of natural selection. After twelve generation, they observed for a major gene involved in vernalization response that a high level of genetic diversity was maintained due to population differentiation for each location and new alleles emerged in two out of three site-specific populations and in this way "withinpopulation diversity despite local genetic drift and natural selection" was maintained (Rhone et al. 2008).

The seed weight of wheat populations was observed to decrease marginally (non-significantly at $\mathrm{P}=0.70$ ) for an average of $-0.05 \mathrm{~g}$ per year during ten generations of natural selection (Goldringer et al. 2001b). For two of our lentil cultivars, we observe a stable or slightly increasing seed weight (Schwarze Linse and 
Gestreifte Linse) and significantly increasing seed weight at one location for Pisarecka Perla. Two explanations are possible: i) there is no effect on seed weight by natural selection, or ii) there was no genetic variation within Schwarze Linse and Gestreifte Linse. The second explanation seems more likely, since significant and continuous site-specific development of seed weight was observed in Pisarecka Perla in both directions.

With the homogenous multiplication of all populations at one location, we focus on genetic differences between populations and exclude possible 'seed source' effects, which may have influenced the results obtained by Horneburg and Becker (2008). Stelling et al. (1994) observed large variation in the seed yield within faba bean varieties from different seed sources with a superior yield from those seed lots, where a higher degree of cross-fertilization was observed. In the same study, varieties of dry peas did not reveal significant seed source effects.

In conclusion, site-specific natural selection did not lead to a site-specific adaptation in terms of yield. However, significant changes of Pisarecka Perla under 'stress-prone' conditions at Tangsehl in seed weight and flowering time led to an overall advantage in seed yield in more favorable environments (Reinshof, Schönhagen). For the reason that lentil has an indeterminate growth, earlier flowering extends the season length under low-stress conditions and results in a higher seed yield. 


\section{REFERENCES}

Allard RW (1990) The Genetics of Host-Pathogen Coevolution: Implications for Genetic Resource Conservation. Journal of Heredity 81:1-6.

Becher T (2016, unpublished) Standortspezifische Populationsentwicklung durch natürliche Selektion am Beispiel der Linse. M. Sc. Thesis, Universität Kassel (Witzenhausen).

Becker HC, Bergmann H, Jantsch P, Marggraf R (2002) Darstellung und Analyse von Konzepten des Onfarm-Managements pflanzengenetischer Ressourcen unter besonderer Berücksichtigung der ökonomischen Rahmenbedingungen in Deutschland. Studie für das Bundesministerium für Verbraucherschutz, Ernährung und Landwirtschaft. No. 317-7723-2/1, Göttingen.

Berthaud J (1997) Strategies for conservation of genetic resources in relation with their utilization. Euphytica 96:1-12.

Bockelmann M (2017, unpublished) Standortspezifische Populationsentwicklung durch natürliche Selektion am Beispiel der Linse, im zweijähringen Test. M. Sc. Thesis, Georg-August-Universität, Göttingen.

Bretting PK, Duvick DN (1997) Dynamic Conservation of Plant Genetic Resources. Adv Agron 61:1-51. doi:10.1016/S0065-2113(08)60661-6.

Brumlop S, Finckh MR (2013) Auswinterung im Jahr 2011/12: Auswirkungen auf WinterweizenLiniensorten und Winterweizenpopulationen in der F10. 12. Wissenschaftstagung Ökologischer Landbau:192-195.

Cavanagh C, Morell M, Mackay I, Powell W (2008) From mutations to MAGIC: resources for gene discovery, validation and delivery in crop plants. Current opinion in plant biology 11:215-221. doi:10.1016/j.pbi.2008.01.002.

de Smet GMW, Scharen AL, Hockett EA (1985) Conservation of powdery mildew resistance genes in three composite cross populations of barley. Euphytica 34:265-272.

Enjalbert J, Goldringer I, Paillard S, Brabant P (1999) Molecular markers to study genetic drift and selection in wheat populations. Journal of Experimental Botany 50:283-290. doi:10.1093/jexbot/50.332.283.

Erskine W (1983) Relationship between the yield of seed and straw in lentil. Field Crops Research 7:115121. doi:10.1016/0378-4290(83)90016-3.

Erskine W, El Ashkar F (1993) Rainfall and temperature effects on lentil (Lens culinaris) seed yield in Mediterranean environments. Journal of Agricultural Science 121:347-354.

Finckh MR (2007) Conservation and generation of genetic resources through development of modern landraces of field crops. Why we need co-evolution in the field. 9. Wissenschaftstagung Ökologischer Landbau.

Finckh MR (2008) Integration of breeding and technology into diversification strategies for disease control in modern agriculture. European Journal of Plant Pathology 121:399-409. doi:10.1007/s10658-008-9273-6. 
Finckh MR, Gacek E, Goyeau H, Lannon C, Merz U, Mundh C, Munk L, Nadziak J, Newton A, VallavieillePope $C$ de, et al. (2000) Cereal variety and species mixtures in practice, with emphasis on disease resistance. Agronomy, EDP Sciences 20:813-837.

Finckh MR, Steffan P, Brumlop S, Goldringer I (2009) Diversität in der F5 von dynamisch evolvierten Weizen Composite Cross Populationen. 10. Wissenschaftstagung Ökologischer Landbau:256-258.

Frese L, Germeier C (2016) Reisebericht - Gif-sur-Yvette, Frankreich. Besuch der INRA am 22. Juni 2015 im Rahmen des Projektes "Innovative approaches to optimize genetic diversity for sustainable farming systems of the future" - INSUSFAR, Workpackage 4, Data management. Journal für Kulturpflanzen (JfK) 68:14-17.

Frese L, Nachtigall M, Rode J, Ordon F, Léon J (2012) Netzwerk zur Erhaltung der Anpassungsfähigkeit von Kulturpflanzen (NEA*-KULT), Teilvorhaben Wintergerste. Julius-Kühn-Archiv; 436; 111-114. doi:10.5073/jka.2012.436.017.

Goldringer I, Enjalbert J, David J, Paillard S, Pham JL, Brabant P (2001a) Dynamic management of genetic resources: a 13-year experiment on wheat. In: Cooper HD, Spillane C, Hodgkin T (eds), Broadening the genetic base of crop production. CABI, London, pp 245-260.

Goldringer I, Enjalbert J, Raquin A, Brabant P (2001b) Strong selection in wheat populations during ten generations of dynamic management. Genet. Sel. Evol. 0:1-23.

Goldringer I, Prouin C, Rousset M, Galic N, Bonnin I (2006) Rapid differentiation of experimental populations of wheat for heading time in response to local climatic conditions. Annals of botany 98:805-817. doi:10.1093/aob/mcl160.

Hammer K (2003) A paradigm shift in the discipline of plant genetic resources. Genetic Resources and Crop Evolution 50:3-10.

Hammer K (2004) Resolving the challenge posed by agrobiodiversity and plant genetic resources - an attempt. Kassel University Press, Kassel.

Hammer K, Laghetti G (2005) Genetic Erosion - Examples from Italy. Genetic Resources and Crop Evolution 52:629-634. doi:10.1007/s10722-005-7902-x.

Harlan HV, Martini ML (1938) The effect of natural selection in a mixture of barley varieties. Journal of Agricultural Research 57:189-199.

Horneburg B (2003a) Frischer Wind für eine alte Kulturpflanze! Linsen im ökologischen Anbau, ihre Geschichte und Verwendung, Göttingen.

Horneburg B (2003b) Standortspezifische Sortenentwicklung: Eine Studie mit Landsorten der Linse. Schriften zu Genetischen Ressourcen. Band 21.

Horneburg B, Becker HC (1998) Landsorten der Linse - Von der Genbank über den Acker in den Magen. In: Begemann F (ed), Schriften zu Genetischen Ressourcen. ZADI, Bonn, pp 235-238.

Horneburg B, Becker HC (2008) Crop Adaptation in On-Farm Management by Natural and Conscious Selection. A Case Study with Lentil. Crop Science 48:203-212.

Ibrahim KM, Barrett JA (2001) Evolutionary Changes in Cambridge Composite Cross Five of Barley. In: Cooper HD, Spillane C, Hodgkin T (eds), Broadening the genetic base of crop production. CABI, London, pp 271-282. 
Imam AG, Allard RW (1965) Population studies in predominantly self-pollinating species. VI. Genetic variability between and within natural populations of wild oats from differing habitats in california. Genetics 51:40-62.

Lammerts van Bueren ET, Jones SS, Tamm L, Murphy KM, Myers JR, Leifert C, Messmer MM (2011) The need to breed crop varieties suitable for organic farming, using wheat, tomato and broccoli as examples. A review. NJAS - Wageningen Journal of Life Sciences 58:193-205. doi:10.1016/j.njas.2010.04.001.

Léon J, Rode J, Frese L, Ahlemeyer J, Ordon F (2008) Aufbau von genetisch diversen Ramschpopulationen für die Wintergerstenzüchtung. In: Gesellschaft für Pflanzenbauwissenschaften e.V. (ed), Mitteilungen der Gesellschaft für Pflanzenbauwissenschaften (Band 20) und Vortrage für Pflanzenzüchtung (Heft 77). Schmidt \& Klaunig KG, Kiel.

Murphy K, Lammer D, Lyon S, Carter B, Jones SS (2005) Breeding for organic and low-input farming systems. An evolutionary-participatory breeding method for inbred cereal grains. Renewable Agriculture and Food Systems 20:48-55. doi:10.1079/RAF200486.

Negri V, Becker HC, Onnela J, Sartori A, Strajeru S, Laliberté B (2000) A firstinventory of on-farm conservation and management activities in Europe includine examplesof formal and informal sector cooperation. In: Laliberté B, Maggioni L, Maxted N, Negri V (eds), ECP/GR In situ and O-farm Conservation Network. Rome, Italy, pp 14-30.

Paillard S, Goldringer I, Enjalbert J, Trottet M, David J, Vallavieille-Pope C de, Brabant P (2000) Evolution of resistance against powdery mildew in winter wheat populations conducted under dynamic management. II. Adult plant resistance. Theoretical and Applied Genetics 101:457-462. doi:10.1007/s001220051503.

Parzies HK, Spoor W, Ennos RA (2000) Genetic diversity of barley landrace accessions conserved for different lengths of time in ex situ gene banks. Heredity 84:476-486.

Rhone B, Remoue C, Galic N, Goldringer I, Bonnin I (2008) Insight into the genetic bases of climatic adaptation in experimentally evolving wheat populations. Molecular ecology 17:930-943. doi:10.1111/j.1365-294X.2007.03619.x.

Rivière P, Goldringer I, Berthellot J, Galic N, Pin S, Kochko P de, Dawson JC (2013) Response to farmer mass selection in early generation progeny of bread wheat landrace crosses. Renewable Agriculture and Food Systems 30:190-201. doi:10.1017/S1742170513000343.

Sarker A, Singh M, El-Ashkar F, Erskine W, De-Pauw E (2007) Approaches to rationalising selection of test environments for on-farm lentil variety trials in Mediterranean rainfed cropping systems. Australian Journal of Agricultural Research 58:335-341. doi:10.1071/AR05418.

Sarker A, Singh M, Rajaram S, Erskine W (2010) Adaptation of Small-Seeded Red Lentil (Lens culinaris Medik. subsp. culinaris) to Diverse Environments. Crop Science 50:1250-1259. doi:10.2135/cropsci2009.06.0342.

Siddique K, Loss SP, Regan KL, Pritchard DL (1998) Adaptation of lentil to short season Mediterraneantype environments: response to sowing rates. Australian Journal of Agricultural Research 49:10571066.

Stelling D, Malau S, Ebmeyer E (1994) Significance of Seed Source on Grain Yield in Faba Beans (Vida faba L.) and Dry Peas (Pisum sativum L.). Journal of Agronomy and Crop Science 173:293-306. 
Utz HF (2011) PLABSTAT. Software for the statistical analysis of experiments in the area of plant breeding. Institut of Plant Breeding, Seed Science and Populations Genetics, Universität Hohenheim, Hohenheim.

van Hintum TJL, van de Wiel CCM, Visser DL, van Treuren R, Vosman B (2007) The distribution of genetic diversity in a Brassica oleracea gene bank collection related to the effects on diversity of regeneration, as measured with AFLPs. Theoretical and Applied Genetics 114:777-786. doi:10.1007/s00122-006-0456-2.

Vlachostergios DN, Roupakias DG (2008) Response to conventional and organic environment of thirty-six lentil (Lens culinaris Medik.) varieties. Euphytica 163:449-457. doi:10.1007/s10681-008-9712-7.

Weedon O, Haak J, Brumlop S, Heinrich S, Finckh MR (2015) Vergleich der Adaptation von Winterweizenpopulationen mit unterschiedlichem Anbauhintergrund. 13. Wissenschaftstagung Ökologischer Landbau. doi:10.1007/978-3-658-09913-8_1.

Wolfe MS, Baresel JP, Desclaux D, Goldringer I, Hoad S, Kovacs G, Löschenberger F, Miedaner T, $\emptyset$ stergård H, Lammerts van Bueren ET (2008) Developments in breeding cereals for organic agriculture. Euphytica 163:323-346. doi:10.1007/s10681-008-9690-9.

Wood D, Lenné JM (1997) The conservation of agrobiodiversity on-farm: questioning the emerging paradigm. Biodiversity and Conservation 6:109-129. 


\section{PHENOTYPIC AND GENOTYPIC VARIATION WITHIN POPULATIONS}

\subsection{INTRODUCTION}

Genetic diversity is the prerequisite for response to selection and subsequent adaptation of populations to biotic and abiotic factors. The intra-specific variation in gene diversity depends on the mating system of the species and was observed to be higher for predominantly autogamous species as well as their variation in the effective population size, compared to allogamous species (Schoen and Brown 1991).

From the assessment of phenotypic variation across environments between single plants or their progenies for agronomical, phenological, and morphological traits, genetic diversity can be concluded. As an autogamous species, lentil varieties are developed by 'line breeding' using random or visual selection (Becker 2011). In a previous study with the same material, two selection methods, i) single plant selection with subsequent progeny testing and selection, and ii) bulked selection of single plants (mass selection) were compared against natural selection at three farms by Horneburg (2003) and Horneburg and Becker (2008). All methods of selection affected population structure and in their conclusion, natural selection was recommended for the on-farm management with lentil, as "generally the easiest method to use" (Horneburg and Becker 2008). Visual selection may be difficult in the lentil crop stand when "tendrils [...] cause inter-plant entanglement" (Erskine et al. 1990), nevertheless, "the plant density of the selection environment did not affect the efficiency of the selection" and "random plant sampling for seed yield in the $F_{5}$ was as effective as visual plant selection and counting the seeds after harvest". However, for the assessment of other traits than yield with a higher heritability, trait assessment should be done at a plant density $<200$ seeds $\mathrm{m}^{-2}$ to avoid plant entanglement, according to Erskine et al. (1990).

With the developments in biochemistry, molecular marker techniques became available to be employed for direct genotypic variability assessment of plant material independently from its phenotypic performance or appearance. An early study in a composite cross populations of barley using esterase allozyme polymorphisms revealed differences in allelic frequencies for the geographical provenance and allelic variation within local populations (Allard et al. 1972). Monitored over 25 generations, Allard et al. (1972) concluded from their results, that the observed "highly significant changes in allelic frequencies [...] were due to directional selection favoring particular alleles and not to mutation or genetic drift" and "natural selection plays the predominant role in determining the observed patterns of allelic variation". Genetic diversity of local cultivars of garden pea (Pisum sativum L.) conserved on farm or in historical collections (Hagenblad et al. 2014) revealed less genetic diversity between and within accessions compared to field pea landraces (Leino et al. 2013), according to twelve highly polymorphic single sequence repeats (SSR) markers, due to their propagation in much smaller population sizes and originating from a cultivar rather than a landrace. In a bean landrace (Phaseolus vulgaris L.) in Italy, Tiranti and Negri (2007) observed a large phenotypic and genotypic (SSRs) variability between samples obtained from different locations and farmers and significant structuring to subpopulations by on-farm conservation. Studying genetic variation in composite cross populations of wheat under dynamic management during ten generations, Enjalbert et al. (1999) observed highly significant differentiation based on RFLPs (restriction fragment length polymorphisms) diversity between sub-populations derived from site-specific natural selection. Lentil landraces from Southeast Turkey could be characterized by SSRs and AFLPs 
(amplified fragment-length polymorphisms) revealed "sharp differences among landraces over short geographic distances" (Toklu et al. 2009). More recently, single nucleotide polymorphisms (SNPs) were developed by next generation sequencing technology and a first comprehensive genetic map of the $L$. culinaris genome was established (Sharpe et al. 2013). Subsequent linkage and association mapping was done and a linkage map of 563 SNPs was constructed (Fedoruk 2013; Fedoruk et al. 2013). Within a global collection, Lombardi et al. (2014) genotyped 505 cultivars and landraces with 266 genome-wide distributed SNPs, which gave successful amplifications and showed polymorphisms to study gene diversity and genetic structure.

For our genotyping project, we used the SNPs developed from Sharpe et al. (2013) available as 'Kompetitive Allele Specific PCR' (KASPar ${ }^{\mathrm{TM}}$, see e.g. Semagn et al. 2014) assays from KBioscience at LGC Genomics (http://www.lgcgenomics.com).

The objectives are to estimate the within-population phenotypic and genotypic variability and to assess the differences between populations after ten generations of natural selection at three different locations compared to the initial material. Additionally, genotyping of the intermediate populations in the fifth generation of selection will allow us to get an insight into the temporal effect of natural selection. 


\subsection{MATERIALS AND METHODS}

\section{PLANT Genetic MAterials}

For phenotypic analysis, single plant progenies were produced from the initial material and the populations after ten generations of natural selection at three location (see CHAPTER 1.1, 2.2). For the genotypic analysis, an additional 100 seeds per population in fifth generation were taken from the multiplication plot in 2014.

For the production of 100 single-plant progenies per population seeds were taken from the multiplication plots in 2014 and planted with one seed per pot in the greenhouse during winter 2014/15. Single plants in pots were blocked according to population affiliation and harvested separately by hand. Plants had to yield at least 20 seeds to be tested in single-row plots in 2015. Due to difficulties in obtaining enough seeds per plant, for some populations the aim for 100 progenies could not be reached (TABLE 3.1). For the repeated field test in 2016, 50 progenies per population were selected. Selection was done by sorting progenies within each population according to the mean single seed weight calculated after harvest in 2015 and selecting at least every second progeny, including those with the highest and the lowest seed weight. In this way, we aimed to keep the original range in seed weight present at 2015 for each population within the selected progenies for testing in 2016.

TABLE 3.1 Number of progenies per population phenotyped in 2015 and 2016.

\begin{tabular}{llcc}
\hline Cultivar & Population & No. of progenies 2015 & No. of progenies 2016 \\
\hline Pisarecka Perla & PP_0 & 97 & 50 \\
& PP_R_10 & 100 & 50 \\
& PP_S_10 & 100 & 50 \\
& PP_T_10 & 95 & 50 \\
\hline Schwarze Linse & SL_0 & 93 & 50 \\
& SL_R_10 & 100 & 50 \\
& SL_S_10 & 99 & 50 \\
& SL_T_10 & 98 & 50 \\
\hline Gestreifte Linse & GL_0 & 59 & 50 \\
& GL_R_10 & 82 & 50 \\
& GL_S_10 & 52 & 50 \\
& GL_T_10 & 77 & 50 \\
\hline
\end{tabular}

\section{LOCATIONS AND CLIMATIC CONDITIONS}

Progeny testing plots were conducted at Reinshof in 2015 and 2016. Soil and climatic conditions are described in CHAPTER 2.2. 


\section{PHeNOTYPING}

Single plant progenies were tested in single-row plots of approx. $0.45 \mathrm{~m}^{2}$ with 20 seeds sown in April 2015 (row length $=1.2 \mathrm{~m}$; distance between rows $=0.3 \mathrm{~m}$ ) and in double-row plots of approx. $1 \mathrm{~m}^{2}$ with 50 seeds sown in April 2016 (plot length $=1.3 \mathrm{~m}$; distance between rows $=0.3 \mathrm{~m}$; distance between double-row plots $=0.4$ ). Field plots were arranged in a partially replicated block design. In 2015, within the three main blocks of three cultivars, 100 progenies of each population were blocked in sub-blocks. Within sub-blocks, 20 progenies were planted in two replications. Field design in 2016 was similar, but included an additional pseudo-replication of the main blocks by splitting the total of 50 progenies per population into $2 \times 25$ progenies. Within sub-blocks of 25 progenies, 5 progenies were replicated twice, thus in total 10 progenies of each population was grown in two replications.

The whole plants were harvested by hand when ripe, packed in permeable linen or woven plastic bags and air dried for at least one week hanging in rainout shelters. In case of humid weather at harvest or when straw for some populations or selections was still greenish, bags were dried at $25-30^{\circ} \mathrm{C}$ on a hot air dryer indoor at the farm.

Seed and straw weight was taken after threshing dried plants. Seed weight was measured from 100-400 seeds by taking the weight of two or four replications ( $2 \times 50$ or $4 \times 100$ seeds), depending on the availability of seeds.

Leaf size was measured from two detached leaves taken in the field shortly before or at early flowering of the plants. The leaf to be taken for measurement from two different plants were defined to be the third upper fully mature leaf. For most genotypes, this leaf has no tendril at the leaf apex, whereas the upper, not fully mature leafs show a lighter green color and have rolled or curved leaflets, typically with a tendril. Leafs were stored between wet paper tissue until they were scanned with the LI-3100 C area meter (LICOR Biosciences) with an area resolution of $1 \mathrm{~mm}^{2}$.

Field emergence and survival rate was evaluated in single row plots (2015) from counting of all plants at about three weeks past sowing and recounting at harvest. In double row plots (2016), field emergence was estimated indirectly by rating ground coverage after flowering when plants stopped growing more or less and started filling the pods.

Hypocotyl color, as it is visible after field emergence of the seedling, was recorded. For specific populations which showed segregation for this trait, the number of progeny-genotypes with red colored hypocotyl was counted. In very few cases, single plants of different color within a progeny were removed from the plot. Additionally, hypocotyl color served as a morphological marker for the early identification of possible sowing errors in the field.

Flowering was scored on a scale from $0-4$ as described in chapter 2.3 and according to Horneburg (2003), starting when first flowers were observed continuously every second day until full flowering was reached.

Lodging could not be scored in 2015, but in 2016 after a heavy rainfall with strong winds it was scored on a 1-9 scale (not lodging until fully lodging).

Ripening was scored on a scale from 1-9 as described in CHAPTER 2.2. 


\section{GENOTYPING}

\section{Pretest of all available SNP KASPar essays on selected material}

To test whether all 512 available SNP assays at LGC Genomics developed by Sharpe et al. (2013) are polymorphic in our material, 32 seeds of each cultivar, in total 96 seeds, were analyzed. For the pretest, single seeds of 16 different single plant progenies from each of the six selections for extreme seed size (large, small; see CHAPTER 4) of the three cultivars were chosen. DNA extraction was done from the single seed by a protocol developed at the LGC laboratory in Berlin, Germany. The extracted DNA was then sent for analysis to LGC in Hoddesdon, UK.

From the 512 available SNPs, 488 gave valid data. The genotypic data of 488 SNPs were analyzed in the M.Sc. thesis of Zhong (2017, unpublished) and 147 polymorphic SNPs were selected.

\section{Genotyping with preselected SNPs of single-plant progenies}

For each population, single seeds of all available single-plant progenies were taken for DNA extraction and subsequently genotyped as described before. In case of less than 100 progenies available for certain populations, randomly chosen single seeds from the multiplication plots in 2014 were taken to reach 100 samples per population.

Of the 159 SNPs selected for analysis, 148 have successfully generated data. One additional SNP (LcC00148p533) was excluded from further analysis, due to missing data of more than $50 \%$ across the three cultivars. Thus, the following results are obtained from the analysis with 147 SNPs. In cultivar SL, SNP Contig14652 gave a heterozygous result (TG) for more than $99 \%$ of the individuals across populations, whereas individuals from cultivar GL are homozygous with TT; PP is polymorphic for this marker with TG and TT for 11 and 89 individuals respectively in population PP_0; in the populations T_5 and T_10, additionally few homozygous individuals with GG were found. 


\section{STATISTICAL ANALYSIS}

The field data was evaluated by the analysis of variance (ANOVA) in PLABSTAT (Version 3Bwin, Utz 2011). The un-replicated data was analyzed separately for each cultivar and year by the following model:

$$
x_{i j}=\mu+p_{i}+s_{i j}
$$

where $x_{i j}$ is the observed value, $\mu$ is the general mean of the experiment, $p_{i}$ is the effect of the population, and $s_{i j}$ is the effect of progenies within the population and includes the residual error.

To obtain the 'true' experimental error from the replicated progenies, in a second step the variance components were calculated separately for each cultivar and year only from replicated entries (20 and 10 replicated entries in 2015 and 2016, respectively) with the following model:

$$
x_{i j k}=\mu+p_{i}+s_{i j}+r_{i k}+e_{i j k}
$$

with the replication $r_{i k}$ effect and the residual experimental error $\mathrm{e}_{\mathrm{ijk}}$.

For the 50 entries replicated during two years, the following model was applied:

$$
x_{i j k}=\mu+y_{i}+p_{j}+s_{i j k}+y p_{i j}+e_{i j k}
$$

with the year effect $y_{i}$ and the interaction effect of year and population $y p_{i j}$.

Post-hoc mean comparisons were done by Tukey's HSD (honestly significant difference) test. The HSD values were calculated 'by hand' in Microsoft Excel (Version 2010) using the mean squares and degrees of freedoms (or alternatively the standard errors) given in the ANOVA table by PLABSTAT and the respective $q$-value from the 'Studentized $Q$ table' for a level of significance of $5 \%(P=0.05)$; in few cases for $10 \%$ $(P=0.1)$.

Principle component analysis (PCA) was done on the statistical platform 'R Studio' (Version 1.0.136; RStudio Team 2015) using the function 'prcomp()' and subsequent hierarchical clustering was done with the function ' $h c p c()^{\prime}$ ' (Hierarchical Clustering on Principle Components) from the package 'FactoMineR' (Husson et al. 2009).

Genotypic data were analyzed by classical multidimensional scaling (MDS) and hierarchical clustering using the non-parametric population structure software 'AWclust' written for R with a GUI interface (Gao and Starmer 2008). It uses the 'allele sharing distance' (ASD) and then applies 'Ward's-minimum-variance' criterion (Ward 1963; Ward and Hook 1963) directly to the similarity matrix. The number of cluster referring to the estimated number of populations is calculated by the gap statistic of Tibshirani et al. (2001). The developer of AWclust state as an advantages of their non-parametric method, that assumptions about the population models are not required. The software enables to infer the optimal number of populations in the sample. SNPs alleles were coded 0 for the most frequent one, 1 for the heterozygous, 2 for the second allele variant, and missing data points are coded as -1 . The ASD matrix calculated from AWclust was exported and used for the cluster analysis within populations with the 'Unweighted Pair Group Method with Arithmetic mean' (UPGMA; Sokal and Michener 1958) in R Studio using the functions 'hclust()' and 'plot(as.dendrogram())' from the package 'Dendextend' by Galili (2015). 


\subsection{RESULTS}

\section{PHENOTYPIC RESULTS}

Single plant progeny testing for the initial population and populations in the $10^{\text {th }}$ generation of site-specific natural selection exposed significant variation between these four populations for most traits in Pisarecka Perla, for yield in 2015 and yield, seed weight and flowering across both years in Schwarze Linse, and for yield and flowering across both years in Gestreifte Linse (TABLE 3.2). Highly significant variation within these populations was observed in Pisarecka Perla and Schwarze Linse for seed weight and flowering, whereas in Gestreifte Linse none of the traits revealed significant variation within populations when analyzed across both test years.

The year of testing had a significant effect on the yield, especially for Schwarze Linse. Due to a large infection of virus diseases on the plants in 2016, as scored with the highest infection of $24-32 \%$ infected plants in all populations of Schwarze Linse and in the populations in generation 10 of Pisarecka Perla, seed yield was lower in 2016 with up to $70 \%$ compared to 2015 for the latter populations (TABLE 3.3). In Schwarze Linse, seed yield was lower by 35-51\%. Straw was less affected compared to seed yield in Pisarecka Perla and Schwarze Linse. For Gestreifte Linse higher seed and straw yield means were observed in the second year, except for populations under natural selection at Reinshof and Tangsehl with a reduced seed yield of $30-35 \%$ and a higher disease score mean with $14-19 \%$, compared to the other populations (GL_0, GL_S_10). 
TABLE 3.2 Variance components with their significance levels from the F-test ${ }^{a)}$ and heritability values $\left(h^{2}\right)$ for kernel yield (KY), straw yield (SY), total yield (TY), seed weight (SW), sum of flowering scores (FTsum), leaf size scan (LScan), and scores for ripening, disease, and plant density; calculated from 20 and 10 replicated progenies in the years 2015 and 2016, respectively, and across both years from 50 progenies.

\begin{tabular}{|c|c|c|c|c|c|c|c|c|c|c|c|c|c|c|c|c|}
\hline \multirow[b]{2}{*}{ Year } & \multirow[b]{2}{*}{ Trait } & \multicolumn{5}{|c|}{ Pisarecka Perla } & \multicolumn{5}{|c|}{ Schwarze Linse } & \multicolumn{5}{|c|}{ Gestreifte Linse } \\
\hline & & Population & Progeny & Replication $^{\text {b) }}$ & Residual & $h^{2}$ & Population & Progeny & Replication & Residual & $h^{2}$ & Population & Progeny & Replication & Residual & $h^{2}$ \\
\hline \multicolumn{17}{|l|}{2015} \\
\hline & KY & $32.44^{+}$ & 90.45 & 5.51 & 827.5 & 18 & $36.48^{*}$ & 0 & 0 & 677.6 & 0 & $268.5^{* *}$ & 88.73 & 0 & 821.7 & 18 \\
\hline & SY & $799.4^{* *}$ & $779.7^{* *}$ & $0^{c)}$ & 2049 & 43 & $219.0^{* *}$ & 0 & 0 & 2222 & 0 & 21.84 & 75.35 & 0 & 1867 & 7 \\
\hline & TY & $572.8^{* *}$ & $867.7^{+}$ & 29.11 & 3803 & 31 & $347.7^{* *}$ & 0 & 0 & 4245 & 0 & $260.5^{*}$ & 277.3 & 0 & 4048 & 12 \\
\hline & sw & $15.82^{* *}$ & $45.37^{* *}$ & 0 & 16.45 & 85 & 0.007 & 0.027 & 0 & 4.387 & 1 & 0 & $0.636^{+}$ & 0 & 2.893 & 31 \\
\hline & FTsum & $2.184^{* *}$ & 11.84 & 0 & 2.737 & 90 & 0.049 & $0.453^{*}$ & 0 & 1.756 & 34 & $0.221^{* *}$ & $0.325^{*}$ & 0 & 1.277 & 34 \\
\hline & Ripening & 0 & $0.104^{+}$ & 0.009 & 0.555 & 27 & 0 & 0.016 & 0 & 0.502 & 6 & 0 & 0 & 0 & 0.138 & 0 \\
\hline \multicolumn{17}{|l|}{2016} \\
\hline & KY & $114.1^{* *}$ & $203.1^{* *}$ & $17.17^{+}$ & 348.8 & 54 & 0 & 0 & 0.271 & 295.6 & 0 & 93.08 & $864.21 *$ & 0 & 2046 & 46 \\
\hline & sY & $578.5^{* *}$ & 979.7 & 6.631 & 1169 & 63 & 35.01 & 0 & 0 & 1296 & 0 & 19.24 & 478.97 & 0 & 2348 & 29 \\
\hline & TY & $1229 * *$ & $1930^{* *}$ & 65.05 & 2304 & 63 & 4.692 & 0 & 0 & 2312 & 0 & 146.45 & $2589.20^{+}$ & 0 & 7464 & 41 \\
\hline & sw & $14.18^{* *}$ & $27.70^{* *}$ & 1.092 & 34.07 & 62 & 0 & 0.318 & 0 & 3.343 & 16 & 0 & 0.63 & 0 & 8.426 & 13 \\
\hline & FTsum & $2.846^{* *}$ & $5.137^{* *}$ & 0.007 & 0.589 & 95 & $0.062^{* *}$ & $0.727^{* *}$ & 0 & 0.109 & 93 & $0.08^{*}$ & 0.06 & 0 & 0.880 & 12 \\
\hline & Ripening & 0.033 & 0.066 & 0 & 0.595 & 18 & 0 & $0.74^{*}$ & $0.22^{*}$ & 1.641 & 47 & 0.01 & 0 & 0 & 0.640 & 0 \\
\hline & LScan & $2.574 * *$ & $2.912^{*}$ & 0 & 5.198 & 53 & 0 & 0 & 0 & 3.017 & 0 & 0 & 0 & 0 & 3.281 & 0 \\
\hline & Disease & 10.09 & 0 & 1.795 & 173.2 & 0 & 2.577 & 13.55 & 0 & 103.04 & 21 & 6.49 & 0 & 0 & 129.0 & 0 \\
\hline & Density & $36.55^{* *}$ & $36.21 *$ & $21.03^{* *}$ & 70.22 & 51 & 0 & $54.86 * *$ & 1.667 & 58.33 & 65 & 0 & $103.74 *$ & 9.42 & 228.1 & 48 \\
\hline \multicolumn{17}{|c|}{ 2015/16 } \\
\hline & KY & $68.09 * *$ & 24.41 & $1970 * *$ & 624.5 & 7 & $14.89^{* *}$ & $82.74 * *$ & $263.8^{* *}$ & 379.2 & 30 & $30.98^{*}$ & 149.4 & $77.11^{* *}$ & 1481 & 17 \\
\hline & SY & $119.2^{* *}$ & 115.5 & $1211^{* *}$ & 2734 & 8 & $144.3^{* *}$ & 91.97 & $172.6^{* *}$ & 1438 & 11 & $256.8^{* *}$ & 0 & $1493^{* *}$ & 2154 & 0 \\
\hline & TY & $264.3^{* *}$ & 0 & $6288^{* *}$ & 5117 & 0 & $212.6^{* *}$ & $418.4^{*}$ & $853.3^{* *}$ & 2665 & 24 & $478.4^{* *}$ & 242.0 & $844.2^{* *}$ & 6026 & 7 \\
\hline & sw & $21.89 * *$ & $41.23^{* *}$ & $42.19 * *$ & 26.15 & 76 & $0.074^{*}$ & $1.829 * *$ & $9.025^{* *}$ & 2.710 & 57 & 0.020 & 0.554 & $0.740 * *$ & 7.556 & 13 \\
\hline & FTsum & $1.612^{* *}$ & $6.786^{* *}$ & $1.233^{* *}$ & 2.146 & 86 & $0.048^{* *}$ & $0.536^{* *}$ & $0.160 * *$ & 1.096 & 49 & $0.037 * *$ & 0.084 & $2.791^{* *}$ & 0.889 & 16 \\
\hline & Ripening & $0.023 * *$ & 0.043 & $0.827^{* *}$ & 0.657 & 12 & 0 & 0.101 & 7.242 & 1.044 & 16 & $0.004^{+}$ & 0.006 & $0.101 * *$ & 0.311 & 4 \\
\hline
\end{tabular}

a) Significance levels from the F-test in ANOVA is denoted by **, $*$, and + for P-values $=0.01,0.05$, and 0.1 , respectively.

b) Replication is identical to Year for ANOVA of two-year data $(2015 / 16)$

c) Negative estimates. 
TABLE 3.3 Mean yield per population in 2015, 2016, and across years, absolute and relative differences for comparison between years, and disease scoring in 2016.

\begin{tabular}{|c|c|c|c|c|c|c|c|c|c|c|c|c|c|}
\hline \multirow[b]{2}{*}{ Trait } & & \multicolumn{4}{|c|}{ Pisarecka Perla } & \multicolumn{4}{|c|}{ Schwarze Linse } & \multicolumn{4}{|c|}{ Gestreifte Linse } \\
\hline & & PP_0 & R_10 & S_10 & T_10 & SL_0 & R_10 & S_10 & T_10 & GL_0 & R_10 & S_10 & T_10 \\
\hline \multirow[t]{5}{*}{ Seed yield [g] } & 2015 & $98.5 a b^{a)}$ & $107.2 \mathrm{~b}$ & $89.6 a$ & $98.8 \mathrm{ab}$ & $46.2 a$ & $62.5 b$ & $54.0 \mathrm{ab}$ & $54.9 a b$ & $128.3 a$ & $151.1 \mathrm{~b}$ & $125.3 a$ & $155.1 b$ \\
\hline & 2016 & $55.9 b$ & $33.8 \mathrm{a}$ & $23.8 a$ & $31.2 \mathrm{a}$ & $28.0 a$ & $30.5 a$ & $28.7 a$ & $35.8 a$ & $151.9 b$ & $97.5 a$ & $147.8 \mathrm{~b}$ & $109.6 a$ \\
\hline & $2015 / 16$ & $78.7 \mathrm{~b}$ & $66.7 a$ & $58.2 \mathrm{a}$ & $64.0 \mathrm{a}$ & $35.6 a$ & $44.7 \mathrm{~b}$ & $41.6 a b$ & $44.9 \mathrm{~b}$ & $141.2 \mathrm{~b}$ & $124.9 a$ & $134.8 \mathrm{ab}$ & $131.8 \mathrm{ab}$ \\
\hline & Difference & 42.6 & 73.4 & 65.8 & 67.5 & 18.2 & 32.0 & 25.3 & 19.1 & -23.6 & 53.6 & -22.5 & 45.5 \\
\hline & rel. Diff. [\%] & 56.8 & 31.5 & 26.6 & 31.6 & 60.6 & 48.8 & 53.2 & 65.3 & 118.4 & 64.5 & 117.9 & 70.6 \\
\hline \multirow[t]{5}{*}{ Straw yield [g] } & 2015 & $215.3 a$ & $249.2 b$ & $262.8 \mathrm{~b}$ & $232.3 a b$ & $168.3 a$ & $179.4 a$ & $176.3 a$ & $197.9 \mathrm{~b}$ & $222.1 a$ & $207.5 a$ & $206.5 a$ & $222.6 a$ \\
\hline & 2016 & $229.0 b$ & $189.9 a$ & $166.4 a$ & $164.1 \mathrm{a}$ & $154.3 a$ & $151.8 \mathrm{a}$ & $162.4 a b$ & $177.5 b$ & $305.4 b$ & 249.1a & $282.3 b$ & $244.0 a$ \\
\hline & $2015 / 16$ & $222.1 \mathrm{~b}$ & $213.7 \mathrm{~b}$ & $215.2 \mathrm{ab}$ & $193.9 a$ & $160.7 a$ & $163.6 a$ & $169.6 a$ & $188.7 \mathrm{~b}$ & $264.3 \mathrm{~b}$ & $226.7 a$ & $245.0 \mathrm{~b}$ & $232.2 \mathrm{ab}$ \\
\hline & Difference & -13.7 & 59.3 & 96.4 & 68.2 & 14.0 & 27.6 & 13.8 & 20.4 & -83.3 & -41.6 & -75.8 & -21.5 \\
\hline & rel. Diff. [\%] & 106.3 & 76.2 & 63.3 & 70.6 & 91.7 & 84.6 & 92.1 & 89.7 & 137.5 & 120.0 & 136.7 & 109.6 \\
\hline \multirow[t]{5}{*}{ Total yield [g] } & 2015 & $313.7 a$ & $356.4 b$ & $352.5 b$ & $331.1 \mathrm{ab}$ & $214.2 a$ & $242.0 \mathrm{bc}$ & $230.6 a b$ & $252.7 c$ & $350.3 a$ & $358.6 \mathrm{ab}$ & $331.7 a$ & $377.7 a$ \\
\hline & 2016 & $284.9 \mathrm{~b}$ & $223.7 a$ & $190.2 a$ & $195.3 a$ & $182.3 a$ & $182.4 a$ & 191.1ab & $213.3 b$ & $457.2 b$ & $346.6 a$ & $430.1 b$ & $353.6 a$ \\
\hline & 2015/16 & $300.8 b$ & $280.4 a b$ & $273.4 a$ & $258.0 a$ & $196.6 a$ & $208.4 a$ & $210.7 a$ & $233.6 \mathrm{~b}$ & $405.5 b$ & $351.7 a$ & $379.7 a b$ & $364.1 \mathrm{ab}$ \\
\hline & Difference & 28.8 & 132.7 & 162.3 & 135.8 & 31.9 & 59.6 & 39.4 & 39.4 & -106.9 & 12.0 & -98.4 & 24.1 \\
\hline & rel. Diff. [\%] & 90.8 & 62.8 & 54.0 & 59.0 & 85.1 & 75.4 & 82.9 & 84.4 & 130.5 & 96.7 & 129.7 & 93.6 \\
\hline Disease [\%] & 2016 & $17.4 a$ & $24.6 b$ & $28.6 b$ & $31.9 \mathrm{~b}$ & $27.8 a$ & $27.96 a$ & $24.3 a$ & $23.8 \mathrm{a}$ & $9.4 a$ & $19.3 b$ & $11.22 \mathrm{a}$ & $13.9 a$ \\
\hline
\end{tabular}

a) Mean values followed by the same letter row-wise within cultivar are not significantly different in Tukey's-HSD test at P=0.05 
Seed, straw, and total yield mean values differ between populations of the same cultivar with the highest yield observed for the initial populations in Pisarecka Perla and Gestreifte Linse (TABLE 3.4-3.6). In Schwarze Linse, the populations SL_R_10 and SL_T_10 yield significantly higher compared to SL_0 in seeds and in straw for the latter population. Significant variation between progenies was not observed within all populations, but larger coefficient of variation for PP_T_10 compared to the other populations in Pisarecka Perla is noticeable. In Schwarze Linse, significant variance was found within SL_0 for seed yield and larger coefficients of variation compared to the other populations is visible in straw and total yield for the same population. In Gestreifte Linse, population GL_T_10 shows significant variation for yield.

TABLE 3.4 Seed yield [g] mean, standard error (SE), range, variance, and coefficient of variation (CV) per population from two-year field test (2015/16)

\begin{tabular}{lcccccccc}
\hline Population & Mean $^{\text {a) }}$ & SE & Min. & Max. & Range & Variance $^{\text {b) }}$ & CV & N \\
\hline PP_0 & $78.7 b$ & 2.87 & 37.8 & 126.1 & 88.3 & $410.6 \mathrm{~ns}$ & 25.76 & 50 \\
PP_R_10 & $66.6 a$ & 2.57 & 13.7 & 107.1 & 93.4 & $329.3 \mathrm{~ns}$ & 27.23 & 50 \\
PP_S_10 & $58.2 a$ & 1.92 & 23.5 & 103.6 & 80.1 & $184.3 \mathrm{~ns}$ & 23.34 & 50 \\
PP_T_10 & $64.0 a$ & 2.91 & 19.0 & 132.7 & 113.8 & $422.4 \mathrm{~ns}$ & 32.11 & 50 \\
\hline SL_0 & $35.6 a$ & 2.07 & - & 96.0 & - & $214.5^{*}$ & 41.09 & 50 \\
SL_R_10 & $44.7 b$ & 2.15 & 16.6 & 92.1 & 75.6 & $231.7^{+}$ & 34.04 & 50 \\
SL_S_10 & $41.6 a b$ & 2.37 & 18.2 & 104.7 & 86.5 & $281.2 \mathrm{~ns}$ & 40.29 & 50 \\
SL_T_10 & $44.9 b$ & 2.69 & 20.9 & 125.3 & 104.4 & $362.0 \mathrm{~ns}$ & 42.38 & 50 \\
\hline GL_0 & $141.2 b$ & 3.89 & 77.9 & 203.9 & 126.0 & $756.5 \mathrm{~ns}$ & 19.48 & 50 \\
GL_R_10 & $124.9 a$ & 4.27 & 45.1 & 193.5 & 148.5 & $909.7 \mathrm{~ns}$ & 24.15 & 50 \\
GL_S_10 & $134.7 a b$ & 4.58 & 38.7 & 219.9 & 181.2 & $1027.8 \mathrm{~ns}$ & 23.81 & 49 \\
GL_T_10 & $131.8 a b$ & 4.16 & 43.7 & 175.5 & 131.8 & $866.6^{+}$ & 22.34 & 50 \\
\hline
\end{tabular}

a) Mean values followed by the same letter within the same cultivar are not significantly different after Tukey's-HSD test with P=0.05.

b) Significance levels of the effect of progenies within population from the F-test in ANOVA is given with: $* *, *+{ }^{+}$, ns for P-values $=0.01,0.05,0.1$, non-significant, respectively.

TABLE 3.5 Straw yield [g] mean, standard error (SE), range, variance, and coefficient of variation (CV) per population from two-year field test $(2015 / 16)$

\begin{tabular}{|c|c|c|c|c|c|c|c|c|}
\hline Population & Mean $^{\text {a) }}$ & SE & Min. & Max. & Range & Variance $^{\text {b) }}$ & CV & $\mathbf{N}$ \\
\hline PP_0 & $222.1 b$ & 4.84 & 161.4 & 278.2 & 116.8 & $1169.1 \mathrm{~ns}$ & 15.39 & 50 \\
\hline PP_R_10 & $213.7 b$ & 4.70 & 130.5 & 269.5 & 139.0 & $1102.3 \mathrm{~ns}$ & 15.53 & 50 \\
\hline PP_S_10 & $215.2 b$ & 5.20 & 121.7 & 294.8 & 173.1 & 1349.9 ns & 17.08 & 50 \\
\hline PP_T_10 & $193.9 a$ & 6.79 & 86.8 & 310.0 & 223.2 & $2308.1^{+}$ & 24.77 & 50 \\
\hline SL_0 & $160.7 a$ & 4.35 & 75.4 & 269.4 & 194.0 & $947.8 \mathrm{~ns}$ & 19.16 & 50 \\
\hline SL_R_10 & $163.6 a$ & 3.43 & 113.0 & 236.7 & 123.7 & $588.7^{+}$ & 14.83 & 50 \\
\hline SL_S_10 & $169.6 a$ & 3.92 & 104.5 & 227.3 & 122.8 & $767.5 \mathrm{~ns}$ & 16.34 & 50 \\
\hline SL_T_10 & $188.7 b$ & 4.33 & 144.0 & 258.6 & 114.6 & $939.1 \mathrm{~ns}$ & 16.24 & 50 \\
\hline GL_0 & $264.3 c$ & 4.90 & 184.9 & 399.7 & 214.8 & $1201.0 \mathrm{~ns}$ & 13.11 & 50 \\
\hline GL_R_10 & $226.7 a$ & 4.75 & 132.0 & 289.1 & 157.1 & $1129.1 \mathrm{~ns}$ & 14.82 & 50 \\
\hline GL_S_10 & $244.6 b$ & 4.47 & 157.1 & 302.6 & 145.5 & 978.5 ns & 12.79 & 49 \\
\hline GL_T_10 & $232.2 a b$ & 4.41 & 131.1 & 286.8 & 155.8 & $972.4 *$ & 13.43 & 50 \\
\hline
\end{tabular}


TABLE 3.6 Total yield [g] mean, standard error (SE), range, variance, and coefficient of variation (CV) per population from two-year field test (2015/16)

\begin{tabular}{lcccccccc}
\hline Population & Mean $^{\text {a) }}$ & SE & Min. & Max. & Range Variance $^{\text {b) }}$ & CV & N \\
\hline PP_0 & $300.8 c$ & 6.72 & 214.9 & 369.5 & 154.6 & $2257.0 \mathrm{~ns}$ & 15.79 & 50 \\
PP_R_10 & $280.4 b c$ & 6.47 & 164.5 & 360.9 & 196.4 & $2095.6 \mathrm{~ns}$ & 16.33 & 50 \\
PP_S_10 & $273.4 a b$ & 6.23 & 174.0 & 361.5 & 187.6 & $1939.9 \mathrm{~ns}$ & 16.11 & 50 \\
PP_T_10 & $258.0 a$ & 8.76 & 105.3 & 386.3 & 281.0 & $3837.1^{+}$ & 24.01 & 50 \\
\hline SL_0 & $196.6 a$ & 6.29 & 70.6 & 365.6 & 295.0 & $1980.1^{*}$ & 22.64 & 50 \\
SL_R_10 & $208.4 a$ & 5.10 & 133.2 & 328.8 & 195.6 & $1299.0^{+}$ & 17.30 & 50 \\
SL_S_10 & $210.7 a$ & 5.79 & 132.5 & 326.7 & 194.2 & $1674.1 \mathrm{~ns}$ & 19.42 & 50 \\
SL_T_10 & $233.6 b$ & 6.40 & 170.1 & 376.4 & 206.4 & $2050.0 \mathrm{~ns}$ & 19.39 & 50 \\
\hline GL_0 & $405.5 b$ & 7.28 & 268.5 & 542.1 & 273.5 & $2646.3 \mathrm{~ns}$ & 12.69 & 50 \\
GL_R_10 & $351.7 a$ & 8.47 & 177.0 & 469.2 & 292.2 & $3590.1 \mathrm{~ns}$ & 17.04 & 50 \\
GL_S_10 & $379.2 a b$ & 8.51 & 208.6 & 522.9 & 314.4 & $3549.5 \mathrm{~ns}$ & 15.71 & 49 \\
GL_T_10 & $364.1 a$ & 8.03 & 174.8 & 462.3 & 287.5 & $3227.6^{+}$ & 15.61 & 50 \\
\hline
\end{tabular}

a) Mean values followed by the same letter within the same cultivar are not significantly different after Tukey's-HSD test with P=0.05.

b) Significance levels of the effect of progenies within population from the F-test in ANOVA is given with: $* *, *,+$, ns for P-values $=0.01,0.05,0.1$, non-significant, respectively.

TABLE 3.7 Seed weight [mg] mean, standard error (SE), range, variance, and coefficient of variation (CV) per population from two-year field test (2015/16)

\begin{tabular}{lcccccccc}
\hline Population & Mean $^{\text {a) }}$ & SE & Min. & Max. & Range & Variance $^{\text {b) }}$ & CV & N \\
\hline PP_0 & $52.5 c$ & 1.01 & 40.8 & 65.1 & 24.4 & $51.5^{* *}$ & 13.68 & 50 \\
PP_R_10 & $55.2 d$ & 0.79 & 37.1 & 65.5 & 28.4 & $31.3^{* *}$ & 10.14 & 50 \\
PP_S_10 & $48.7 b$ & 1.14 & 27.1 & 60.9 & 33.9 & $64.8^{* *}$ & 16.52 & 50 \\
PP_T_10 & $44.4 a$ & 1.18 & 24.9 & 60.1 & 35.2 & $69.6^{* *}$ & 18.81 & 50 \\
\hline SL_0 & $20.9 a$ & 0.24 & 13.5 & 23.5 & 10.0 & $2.9^{*}$ & 8.10 & 50 \\
SL_R_10 & $21.6 b$ & 0.28 & 18.2 & 32.4 & 14.2 & $3.9 * *$ & 9.11 & 50 \\
SL_S_10 & $21.3 a b$ & 0.30 & 15.7 & 29.8 & 14.1 & $4.4 * *$ & 9.83 & 50 \\
SL_T_10 & $21.5 a b$ & 0.18 & 18.5 & 25.2 & 6.7 & $1.6 \mathrm{~ns}$ & 5.92 & 50 \\
\hline GL_0 & $32.8 a$ & 0.27 & 24.3 & 35.6 & 11.3 & $3.6+$ & 5.77 & 50 \\
GL_R_10 & $32.3 a$ & 0.27 & 26.6 & 35.4 & 8.8 & $3.6 \mathrm{~ns}$ & 5.84 & 50 \\
GL_S_10 & $32.9 a$ & 0.39 & 17.4 & 36.0 & 18.6 & $7.6 \mathrm{~ns}$ & 8.40 & 49 \\
GL_T_10 & $32.9 a$ & 0.23 & 28.4 & 35.8 & 7.4 & $2.6 \mathrm{~ns}$ & 4.91 & 50 \\
\hline
\end{tabular}

a) Mean values followed by the same letter within the same cultivar are not significantly different after Tukey'sHSD test with $\mathrm{P}=0.05$.

b) Significance levels of the effect of progenies within population from the F-test in ANOVA is given with: $* *, *,+$, ns for P-values $=0.01,0.05,0.1$, non-significant, respectively.

Seed weight means differ significantly between all populations of Pisarecka Perla and highly significant variances within populations were found with the highest coefficient of variation in PP_T_10 (TABLE 3.7). Seed weight of the population from Reinshof (SL_R_10) of Schwarze Linse has a significantly higher mean value compared to SL_0 and significant variances are present in all populations, except for SL_T_10. Populations of Gestreifte Linse do not differ significantly for seed yield and variances within populations are not significant, except for $\mathrm{GL}_{-} 0$ at $\mathrm{P}=0.1$. 
Seed weight distributions are plotted for Pisarecka Perla from all available progenies tested in 2015 in FIGURE 3.1. Hereby two distinct groups in PP_0 become visible, one group of progenies with seeds of 40$52 \mathrm{mg}$ weight and a second croup with a larger range of seed weights from 56-73 mg. In PP_R_10, the large majority of progenies range between $54-70 \mathrm{mg}$, in PP_S_10 the majority of progenies ranges between 38-64 mg. In PP_T_10 again two groups are visible, one group ranges around $\pm 45 \mathrm{mg}$ and the second smaller group around $\pm 58 \mathrm{mg}$.
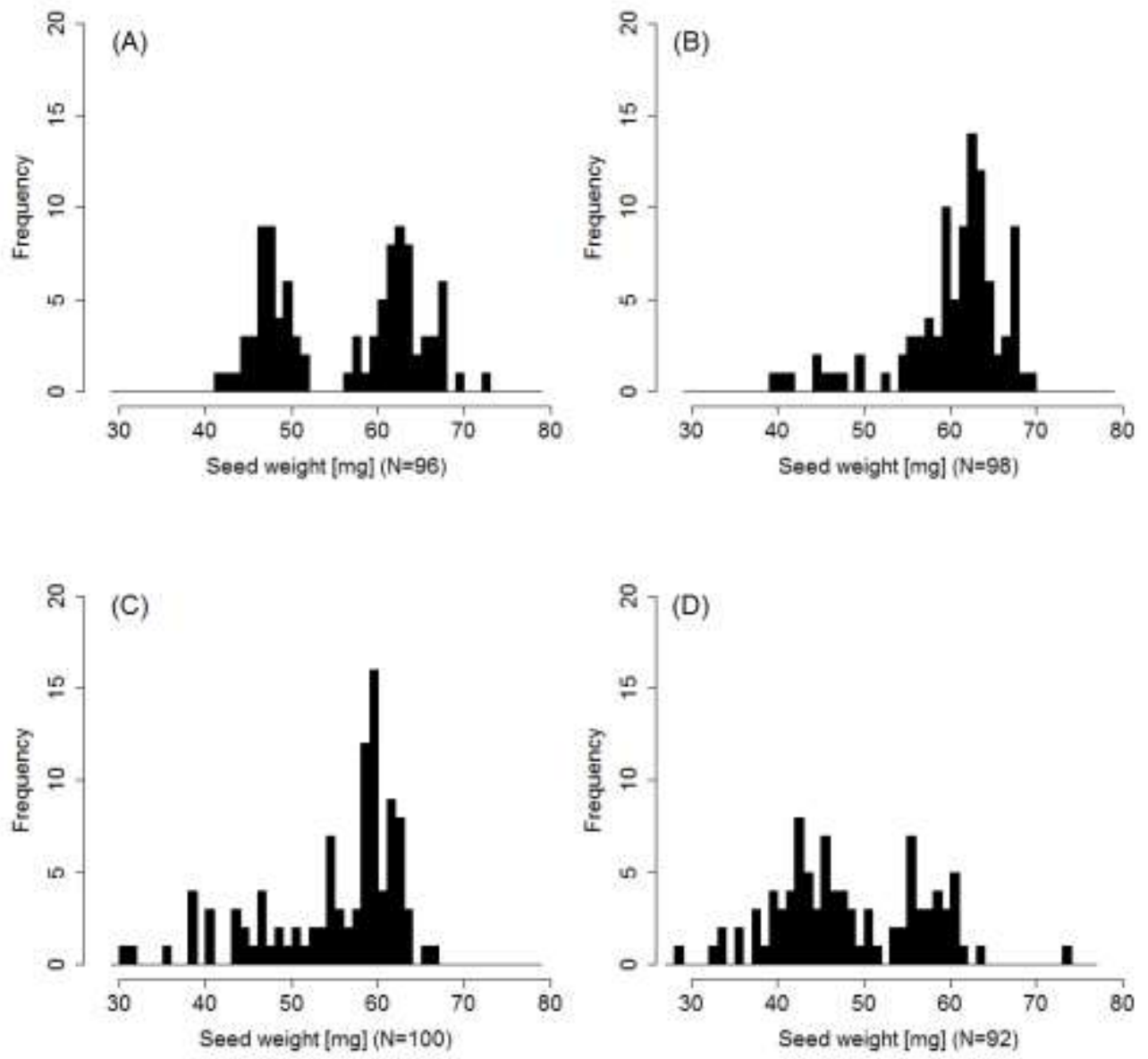

FIGURE 3.1 Seed weight frequency histogram of progenies in the populations of Pisarecka Perla PP_0 (A), PP_R_10 (B), PP_S_10 (C), and PP_T_10 (D) tested in 2015. 

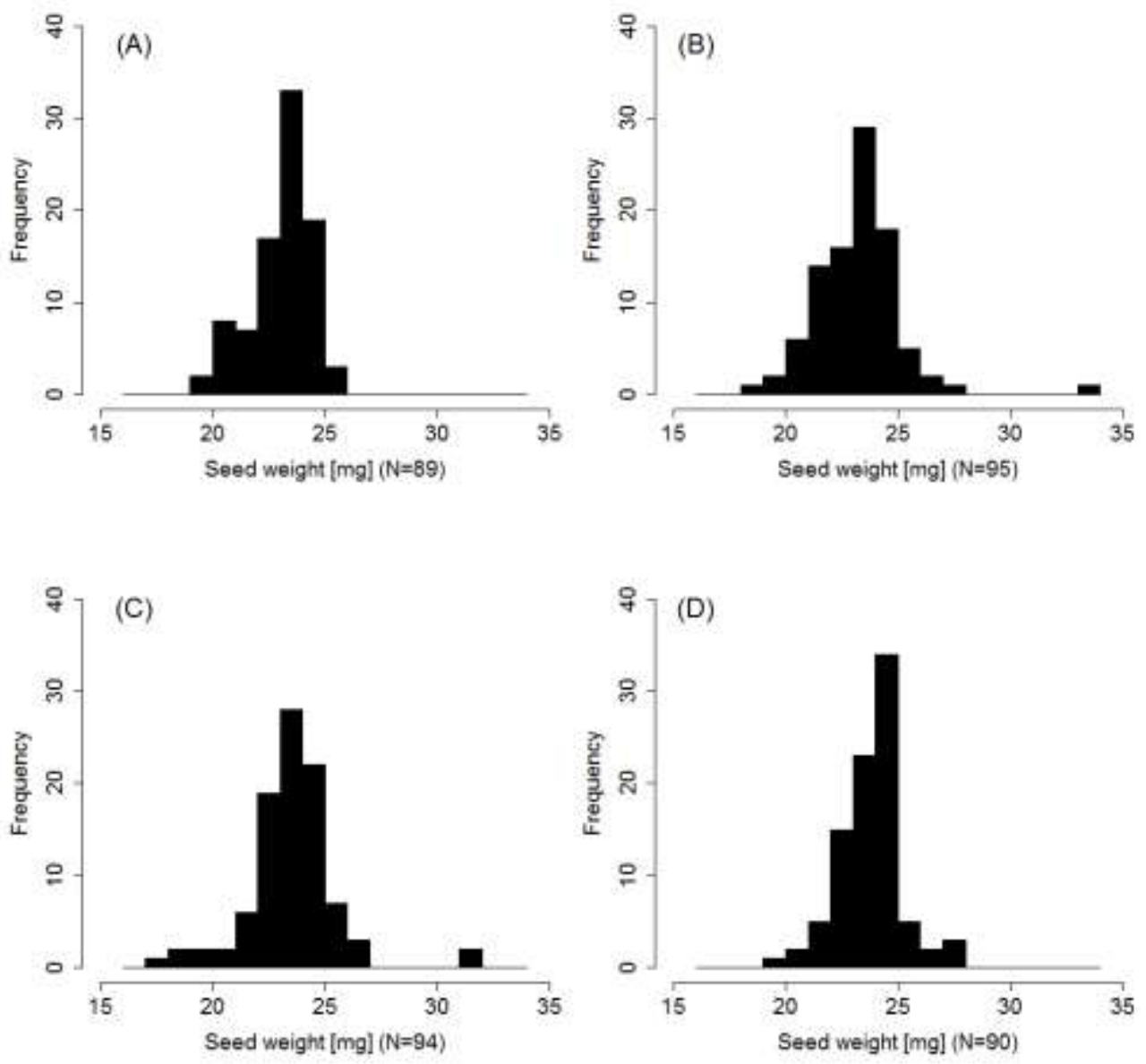

FIGURE 3.2 Seed weight frequency histogram of progenies in the populations of Schwarze Linse SL_0 (A), SL_R_10 (B), SL_S_10 (C), and SL_T_10 (D) tested in 2015.

Seed weight of progenies within populations of Schwarze Linse follow approximately a normal distribution with more than $50 \%$ of progenies ranging from $23-25 \mathrm{mg}$ (FIGURE 3.2). 

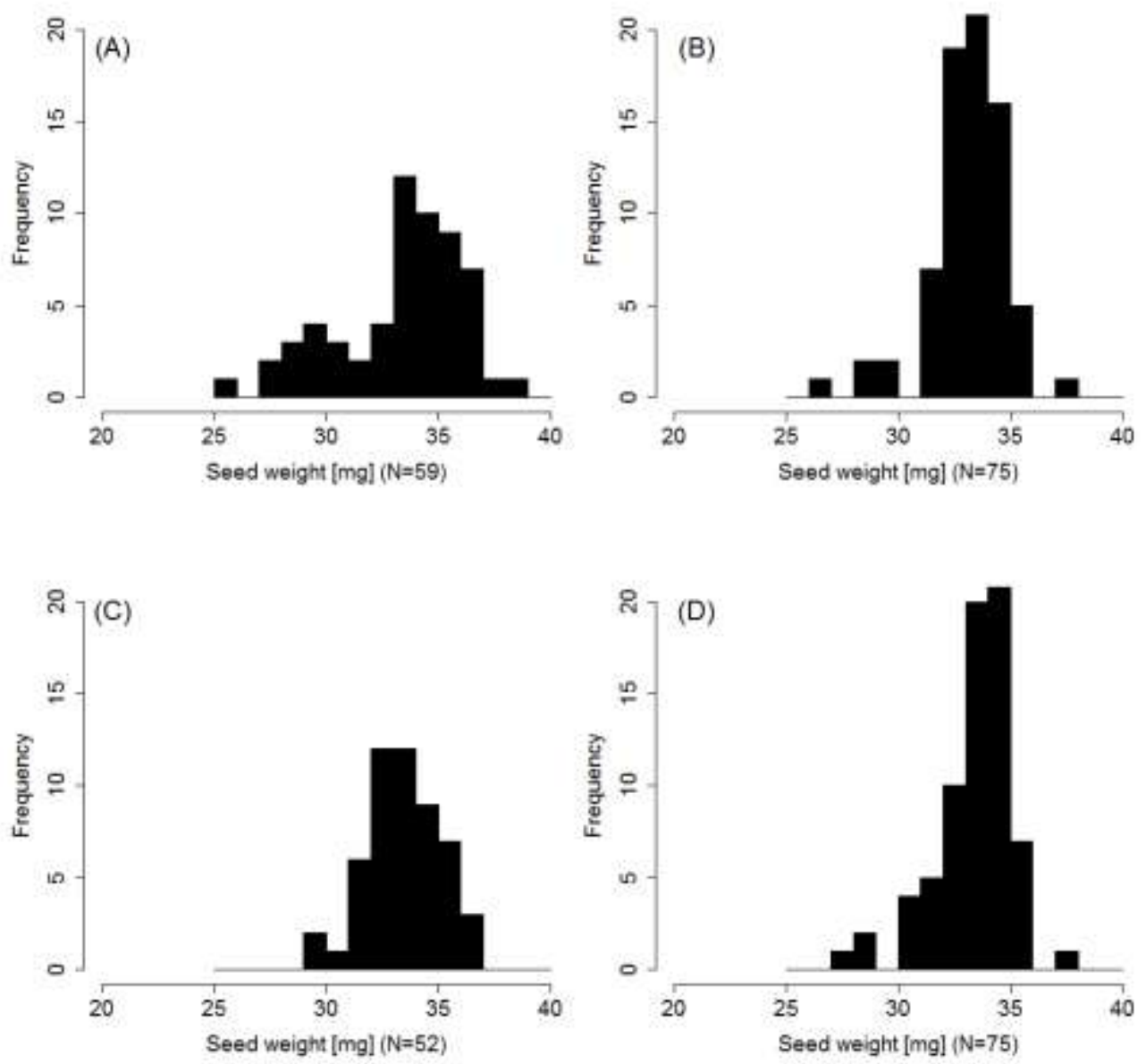

FIGURE 3.3 Seed weight frequency histogram of progenies in the populations of Gestreifte Linse GL_0 (A), GL_R_10 (B), GL_S_10 (C), and GL_T_10 (D) tested in 2015.

Distributions of seed weight within populations of Gestreifte Linse differ between populations (FIGURE 3.3). 

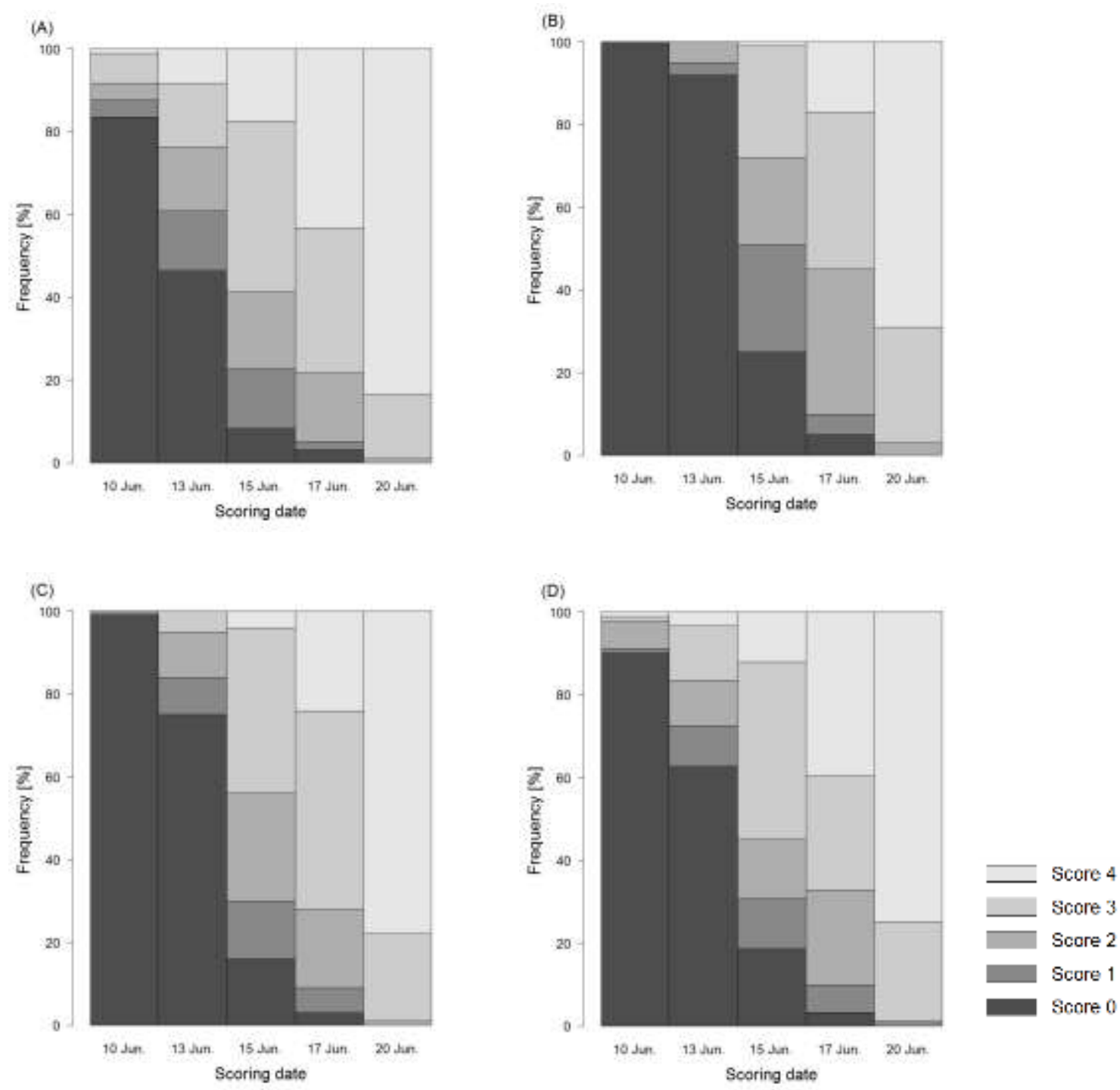

Figure 3.5 Frequency of flowering scores of Pisaracka Perla progenies in population PP_0 (A), PP_R_10 (B), PP_S_10 (C), and PP_T_10 (D) at five time points in 2015.

Flowering scores are plotted in relative frequencies for each date of scoring (FIGURE 3.5-3.7). In PP_0 and PP_T_10 approximately $10-18 \%$ of the progenies were flowering (score $\geq 1$ ) on the first date of scoring (10. June 2015) and three days later, on the second date of scoring, approximately $44-55 \%$ were flowering, whereas in PP_R_10 and PP_S_10 less than 1\% on the first date, and approximately 10-25\% at the second date of scoring were observed flowering (FIGURE 3.5). In PP_R_10 larger proportions of progenies still received flowering scores of $<4$ during later dates compared the other three populations, indicating a larger timespan until full flowering for this population. 

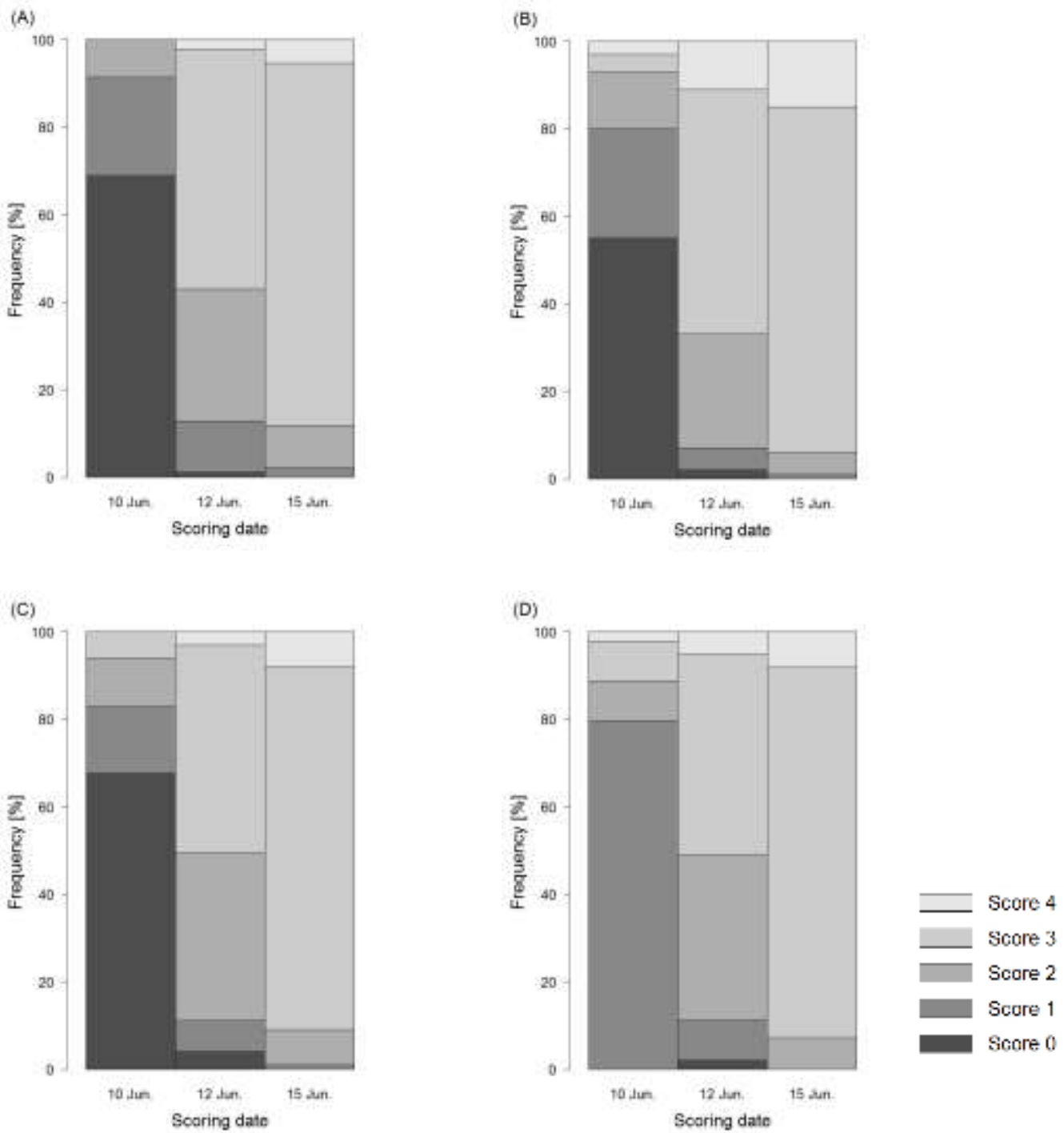

FIGURE 3.6 Frequency of flowering scores of Schwarze Linse progenies in population SL_0 (A), SL_R_10 (B), SL_S_10 (C), and SL_T_10 (D) at three time points in 2015.

Early flowering was scored on $10^{\text {th }}$ of June 2015 in SL_T_10, whereas in the other populations of Schwarze Linse on approximately $55-70 \%$ of the progenies no open flowers were observed at the same date (FIGURE 3.6). During later dates of scoring no clear differences between frequencies of flowering scores for populations of Schwarze Linse are visible. 

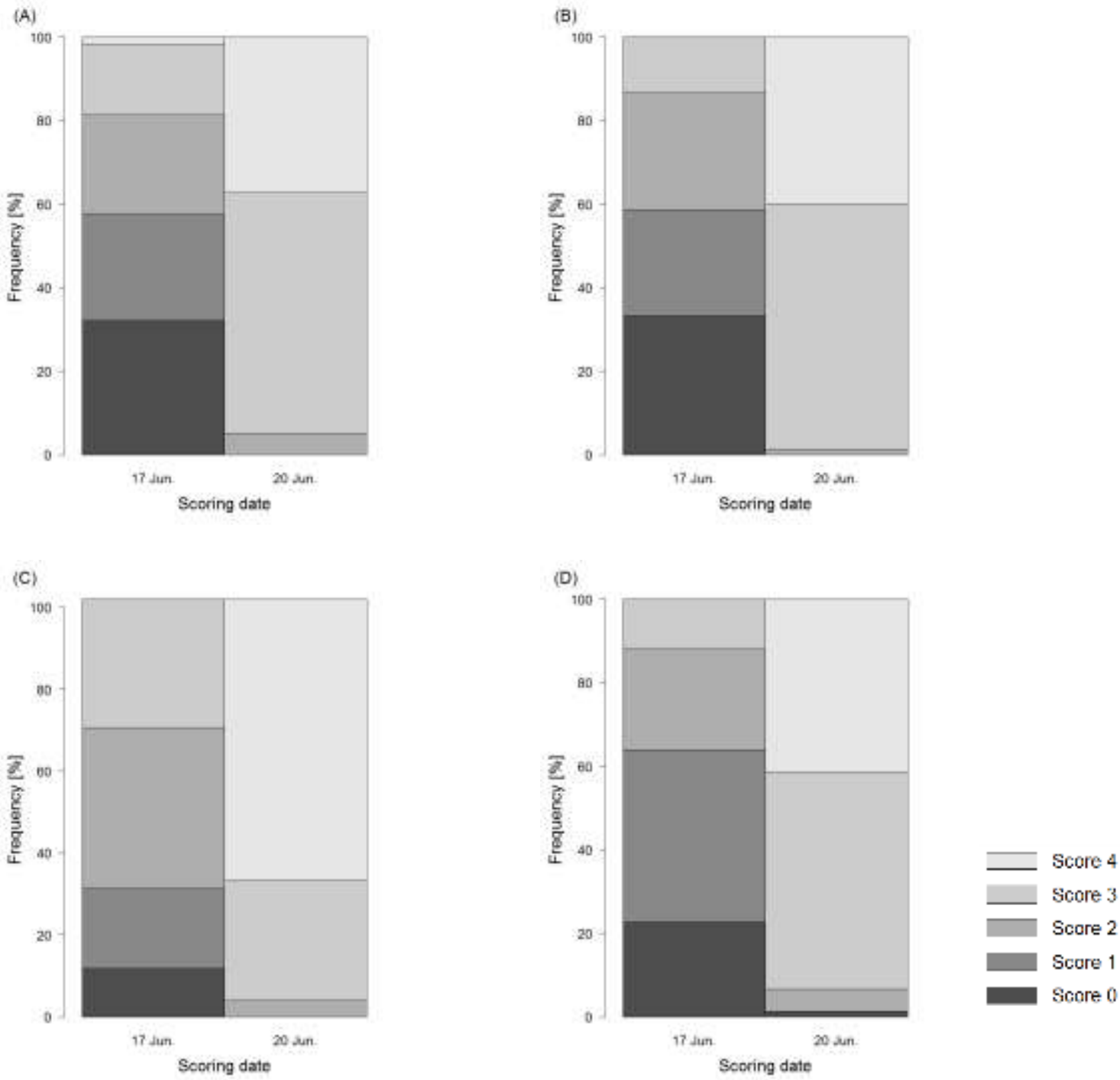

FIGURE 3.7 Frequency of flowering scores of Gestreife Linse progenies in population GL_O (A), GL_R_10 (B), GL_S_10 (C), and GL_T_10 (D) at two time points in 2015.

The first date when first open flowers were observed was seven days later in Gestreifte Linse, compared to the other two cultivars, on $17^{\text {th }}$ June 2015 . Within the populations GL_0, GL_R_10, and GL_T_10 approximately $60 \%$ were scored with $\leq 1$ at the first date of scoring, while GL_S_10 received scores of $\geq 2$ for about $70 \%$ of its single plant progenies (FIGURE 3.7). 
In 2016, a significantly larger leaf size mean was observed for PP_R_10 compared to PP_0 and PP_T_10; mean comparisons of populations within Schwarze Linse and Gestreifte Linse did not reveal significant differences (TABLE 3.8). Highly significant variation was observed within PP_0, but in none of the other populations.

TABLE 3.8 Leaf size scan $\left[\mathrm{cm}^{2}\right]$ mean, standard error (SE), range, variance, and coefficient of variation (CV) per population from one-year field test (2016).

\begin{tabular}{lcccccccc}
\hline Population & Mean $^{\text {a) }}$ & SE & Min. & Max. & Range & Variance $^{\text {b) }}$ & CV & N \\
\hline PP_0 & $11.8 a$ & 0.37 & 6.8 & 17.1 & 10.3 & $6.8^{* *}$ & 22.13 & 50 \\
PP_R_10 & $14.4 b$ & 0.40 & 8.0 & 19.9 & 11.9 & $8.0 \mathrm{~ns}$ & 19.68 & 50 \\
PP_S_10 & $13.4 a b$ & 0.43 & 5.7 & 18.8 & 13.1 & $9.3 \mathrm{~ns}$ & 22.66 & 50 \\
PP_T_10 & $12.1 a$ & 0.42 & 6.2 & 17.4 & 11.2 & $8.9 \mathrm{~ns}$ & 24.60 & 50 \\
\hline SL_0 & $8.1 a$ & 0.17 & 5.8 & 10.5 & 4.7 & $1.4 \mathrm{~ns}$ & 14.64 & 50 \\
SL_R_10 & $7.9 a$ & 0.21 & 5.4 & 11.4 & 6.0 & $2.2 \mathrm{~ns}$ & 18.59 & 49 \\
SL_S_10 & $8.0 a$ & 0.21 & 5.6 & 11.7 & 6.2 & $2.1 \mathrm{~ns}$ & 18.20 & 50 \\
SL_T_10 & $7.8 a$ & 0.18 & 4.6 & 11.0 & 6.4 & $1.7 \mathrm{~ns}$ & 16.68 & 50 \\
\hline GL_0 & $9.4 a$ & 0.19 & 6.4 & 12.1 & 5.7 & $1.8 \mathrm{~ns}$ & 14.09 & 50 \\
GL_R_10 & $8.5 a$ & 0.28 & 4.8 & 12.6 & 7.8 & $3.8 \mathrm{~ns}$ & 23.06 & 50 \\
GL_S_10 & $9.0 a$ & 0.25 & 5.3 & 13.3 & 8.0 & $3.0 \mathrm{~ns}$ & 19.10 & 49 \\
GL_T_10 & $8.5 a$ & 0.25 & 4.3 & 13.1 & 8.9 & $3.0 \mathrm{~ns}$ & 20.49 & 50 \\
\hline
\end{tabular}

a) Mean values followed by the same letter within the same cultivar are not significantly different after Tukey's-HSD test with P=0.05 (calculated from 10 progenies in two replications).

b) Significance levels of the effect of progenies from the F-test in ANOVA, calculated from 10 replicated progenies per population, is given with: $* *,{ }^{*},{ }^{+}$, ns for P-values $=0.01,0.05,0.1$, non-significant, respectively.

In the analysis of principle components, nine phenotypic traits were used to check for phenotypic grouping according to these traits within progenies of the same cultivar (FIGURE 3.8-3.9). The traits involved in the principle component are: Seed (KY), straw (SY), and total yield TY, seed weight (SW), leaf area (LScan), the sum of flowering scoring (FTsum), and scorings of ripening, disease, and density. Within Pisarecka Perla, according to the first and second principle component, flowering and seed weight are differentiating two main groups, which still contain large variation due to yield traits and density versus ripening and disease scoring, all having different directions of interactions. Additionally, the third principle component still explains a proportion of $11.6 \%$ of the variation (FIGURE 3.8). Within cultivar Schwarze Linse and Gestreifte Linse, no clear grouping according to the phenotypic traits assessed became visible by the analysis of principle components (FIGURE 3.9). 

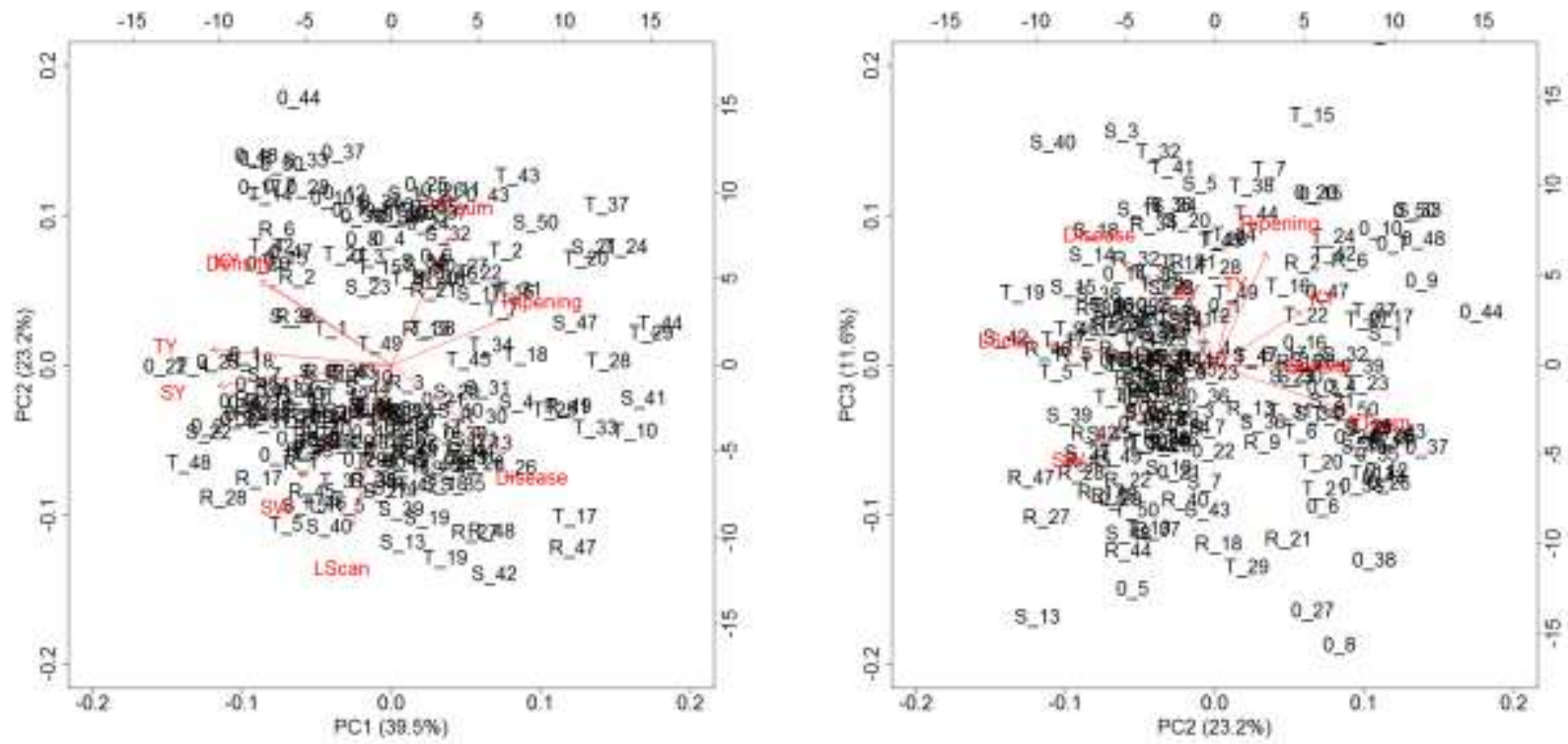

FiguRE 3.8 Principal component biplots of the $1^{\text {st }}$ versus $2^{\text {nd }}$ (left) and the $2^{\text {nd }}$ versus the $3^{\text {rd }}$ principal component calculated from two-year phenotypic data including 9 different traits measured on single plant progenies of the cultivar Pisarecka Perla across four populations $(0, R, S, T)$ with 50 progenies each.
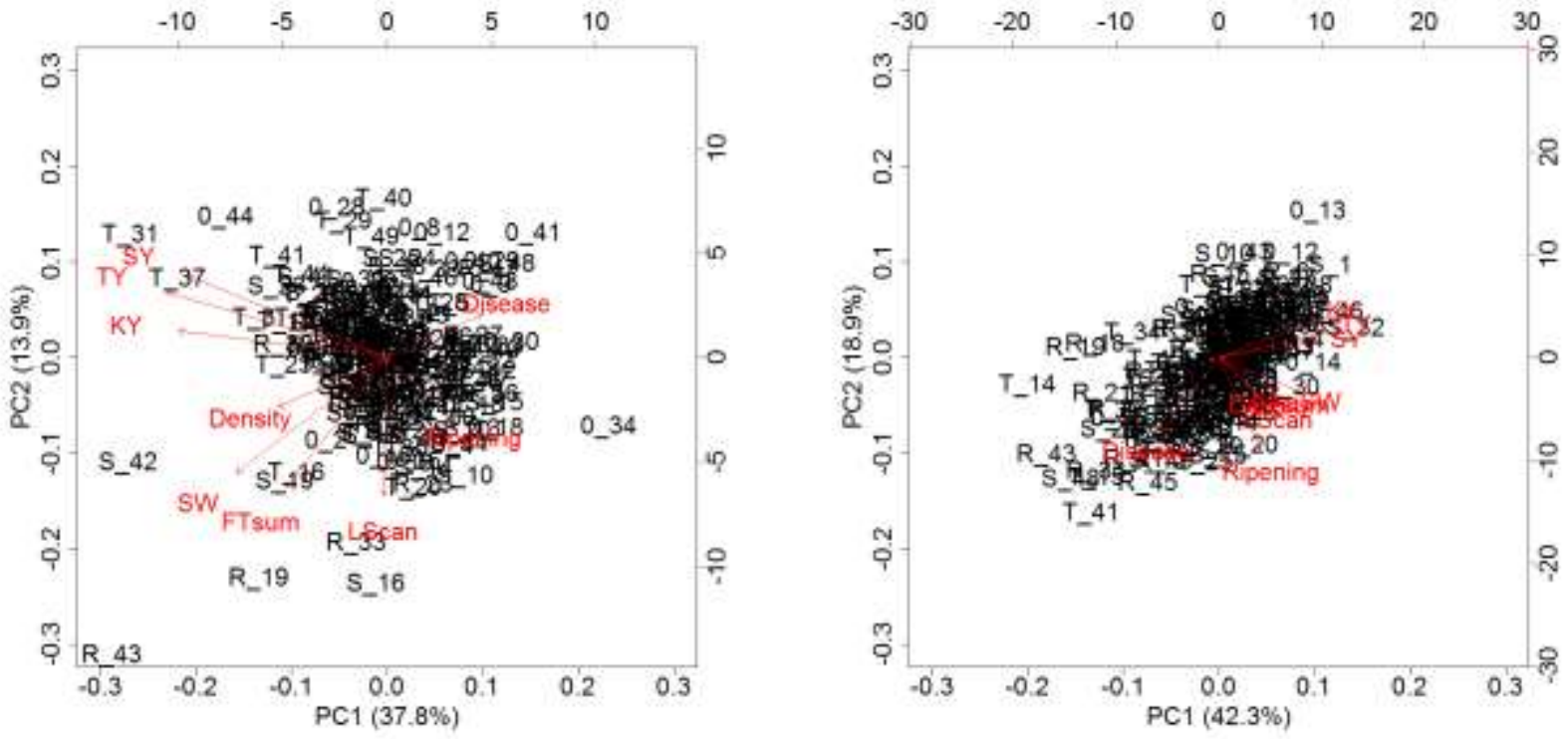

FIGURE 3.9 Principal component biplots of Schwarze Linse (left) and Gestreifte Linse (right) from twoyear phenotypic data including 9 different traits measured on single plant progenies across four populations $(0, R, S, T)$ per cultivar with 50 progenies each. 
To reveal phenotypic grouping within populations of Pisarecka Perla, analysis of principle components was applied separately for each population (FIGURE 3.10). Large interactions to opposite directions were observed for flowering (FTsum) and ripening versus leaf size (LScan) and disease scoring. Flowering is closely correlated with ripening in PP_O and PP_T, yield with plant density scorings and seed weight (SW) with leaf size in all populations, as can be seen from the similar directions of interactions.
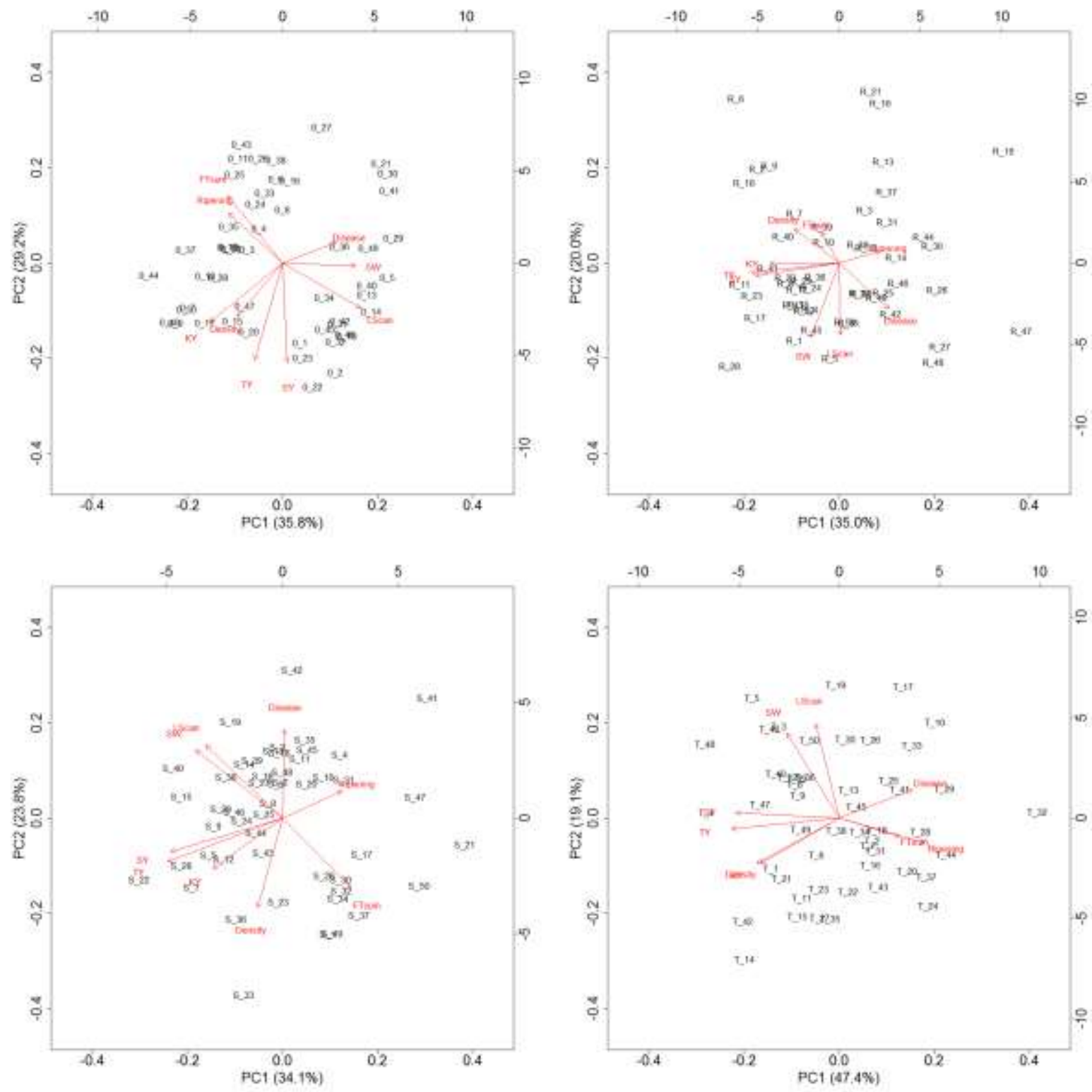

FIGURE 3.10 Principal component biplots of Pisarecka Perla populations PP_0 (upper left), PP_R_10 (upper right), PP_S_10 (lower left), and PP_T_10 (lower right) from two-year phenotypic data including 9 different traits measured on 50 single plant progenies within each population. 
In the next step, hierarchical clustering of principle components was done across the four populations of Pisarecka Perla to find phenotypic clusters and to compare the contribution of each population to the observed clusters (FIGURE 3.11, TABLE 3.9). Four main clusters could be differentiated (FIGURE 3.11), with the first cluster strongly occupied by progenies of PP_T_10 with 21 progenies, 6 progenies of PP_S_10, one of PP_R_10, and none of PP_0 (TABLE 3.9). The second cluster is largely taken by progenies of PP_R_10 and PP_S_10; the third cluster included mainly progenies of PP_0, and in the fourth cluster all populations are involved, PP_R_10 contributes the largest number of progenies to this cluster.

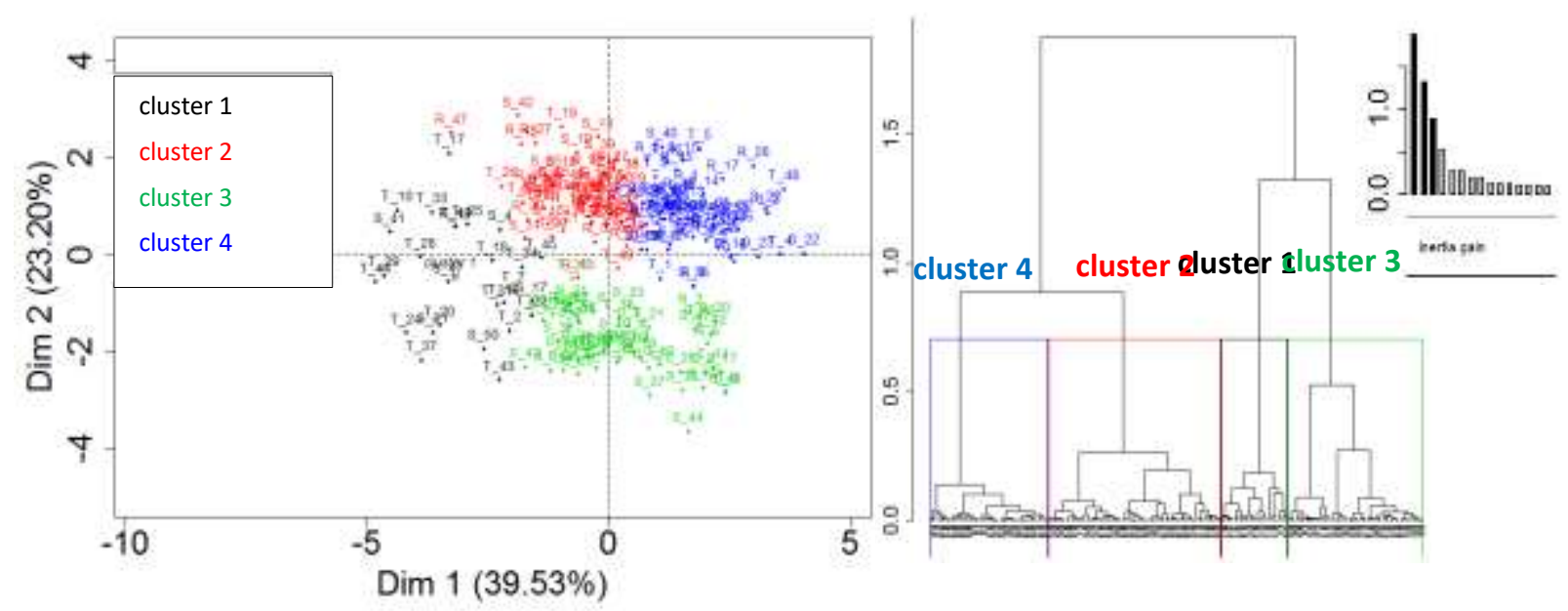

FIGURE 3.11 Hierarchical clustering on principle components of nine phenotypic traits for Pisarecka Perla: Biplot (left), minimum-variance-dendrogram (right), and barplot of the intra-cluster inertia (upper right).

TABLE 3.9 Number of progenies within each cluster from hierarchical clustering of principle components of 9 phenotypic traits.

\begin{tabular}{lccccr}
\hline & \multicolumn{5}{c}{ Cluster } \\
\cline { 2 - 5 } Population & $\mathbf{1}$ & $\mathbf{2}$ & $\mathbf{3}$ & $\mathbf{4}$ & Sum \\
\hline PP_0 & 0 & 5 & 29 & 16 & 50 \\
PP_R_10 & 1 & 22 & 4 & 23 & 50 \\
PP_S_10 & 6 & 23 & 9 & 12 & 50 \\
PP_T_10 & 21 & 10 & 10 & 9 & 50 \\
\hline Sum & 28 & 60 & 52 & 60 & 200 \\
\hline
\end{tabular}


Seed weight and flowering were observed to contribute significantly to phenotypic variation with a relatively high heritability and opposite directions of interactions within Pisarecka Perla and its populations (TABLE 3.2, 3.7; FIGURE 3.8, 3.10). Thus, principle component analysis (PCA) and subsequent hierarchical clustering of principle components was performed for these two traits (FIGURE 3.12). Since PCA is done with only two traits, a similar picture would be obtained when plotting seed weight over flowering score sums, as it is done in FIGURE 3.17 separately for each population of Pisarecka Perla. Five main clusters could be differentiated. The three largest clusters are relatively close to each other. They have overlapping areas and contain 118 (cluster 1), 52 (cluster 3), and 18 (cluster 2) progenies (TABLE 3.10). Two additional small clusters containing seven progenies of PP_0 (cluster 4) and five progenies (four of PP_T_10 and one of PP_S_10 in cluster 5) are at a larger distance from the three main clusters.

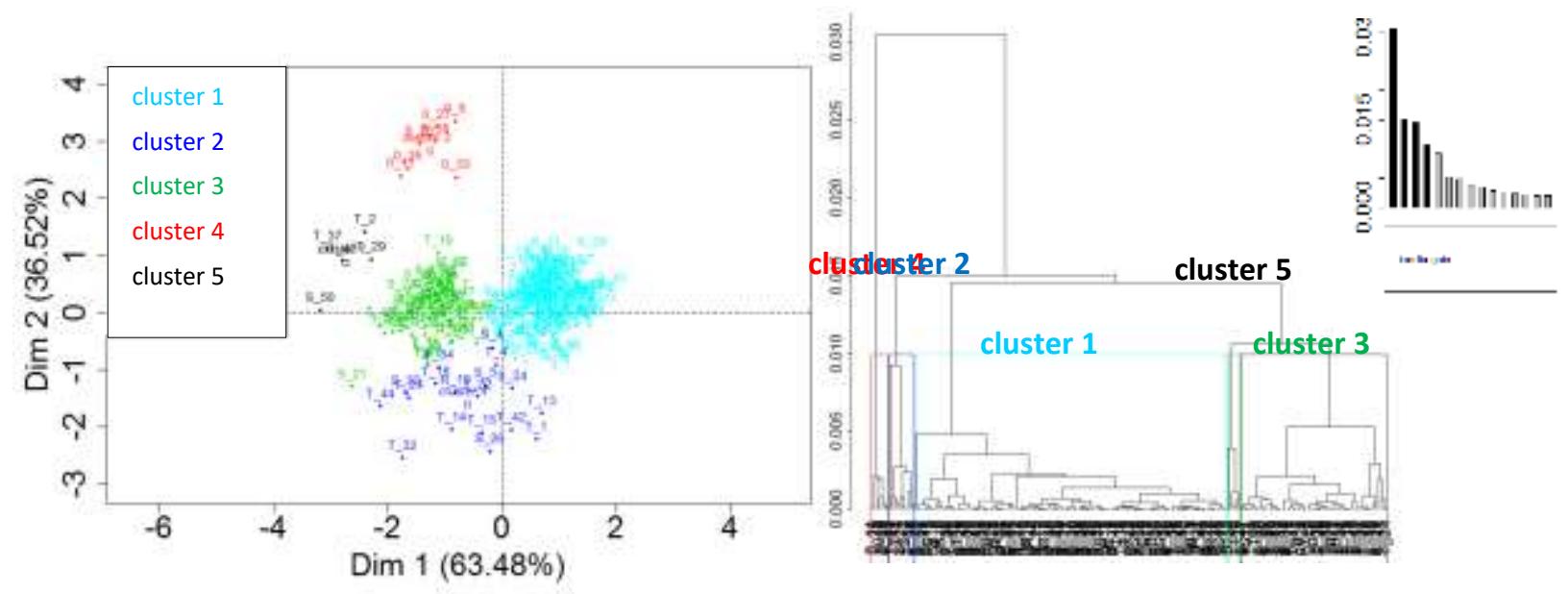

FIGURE 3.12 Hierarchical clustering of principle components for seed weight and flowering in Pisarecka Perla: Biplot (left), minimum-variance-dendrogram (right), and barplot of the intra-cluster inertia (upper right).

TABLE 3.10 Number of progenies within each cluster from hierarchical clustering of principle components of seed weight and flowering.

\begin{tabular}{lcccccc}
\hline & \multicolumn{7}{c}{ Cluster } \\
\cline { 2 - 6 } Population & $\mathbf{1}$ & $\mathbf{2}$ & $\mathbf{3}$ & $\mathbf{4}$ & $\mathbf{5}$ & Sum \\
\hline PP_0 & 21 & 0 & 22 & 7 & 0 & 50 \\
PP_R_10 & 46 & 1 & 3 & 0 & 0 & 50 \\
PP_S_10 & 33 & 5 & 11 & 0 & 1 & 50 \\
PP_T_10 & 18 & 12 & 16 & 0 & 4 & 50 \\
\hline Sum & 118 & 18 & 52 & 7 & 5 & 200 \\
\hline
\end{tabular}




\section{GENOTYPIC RESULTS}

The largest amount of polymorphic markers was observed in the cultivar PP (TABLE 3.11). In cultivar SL few samples show polymorphic results. In population SL_R_5, one individual was identified belonging to cultivar GL and excluded. One of the five individuals in SL_R_10 showing polymorphic results additionally had 21 heterozygous loci. The five individuals in SL_S_5 with polymorphic loci were also heterozygous for 8-56 loci. In population SL_S_10, four individuals are polymorphic and one additional individual has 36 heterozygous loci, but no polymorphisms at any of the non-heterozygous loci. The one individual in population SL_T_5 with 19 polymorphic loci is at the same time heterozygous for 50 other loci. The three individuals differing at 35 loci from the rest of population SL_T_10 are identical for 33 of these 35 SNPs. In cultivar GL, polymorphic or heterozygous samples are even less abundant compared to cultivar SL. In population GL_R_10, one of the two heterozygous samples with 10 loci is at the same time polymorphic homozygous for 16 SNPs. Two of the three samples with polymorphisms in population GL_S_5 are also heterozygous at 8 and 19 loci, respectively. The single individual differing from the other samples in population GL_T_5 at 19 SNPs is at the same time heterozygous in 38 other SNPs.

TABLE 3.11 Results from genotyping with 147 SNP marker.

\begin{tabular}{lcccc}
\hline Population & $\begin{array}{c}\text { Number of } \\
\text { polymorphic } \\
\text { homozygous loci } \\
\text { (number of samples) }\end{array}$ & $\begin{array}{c}\text { Number of } \\
\text { heterozygous } \\
\text { loci }\end{array}$ & $\begin{array}{c}\text { Number of heterozygous } \\
\text { samples with H>5\% } \\
\text { (Number or range of } \\
\text { heterozygous loci) }\end{array}$ & $\begin{array}{c}\text { Number of } \\
\text { samples }\end{array}$ \\
\hline PP_0 & 120 & 101 & $1(83)$ & 100 \\
PP_R_5 & 48 & 82 & $2(63 ; 35)$ & 100 \\
PP_R_10 & 75 & 78 & $2(59 ; 8)$ & 100 \\
PP_S_10 & 111 & 112 & $8(9-50)$ & 99 \\
PP_T_5 & 96 & 114 & $12(9-71)$ & 100 \\
PP_T_10 & 124 & 101 & $10(8-41)$ & 100 \\
\hline SL_0 & 0 & 2 & 0 & 99 \\
SL_R_5 & $30(1)$ & 4 & 0 & 99 \\
SL_R_10 & $70(5)$ & 23 & $1(21)$ & 100 \\
SL_S_5 & $51(5)$ & 103 & $5(8-56)$ & 100 \\
SL_S_10 & $69(4)$ & 37 & $1(36)$ & 100 \\
SL_T_5 & $19(1)$ & 103 & $3(50-84)$ & 100 \\
SL_T_10 & $35(3)$ & 1 & 0 & 104 \\
\hline GL_0 & $75(1)$ & 0 & 0 & 100 \\
GL_R_5 & 0 & 1 & 0 & 99 \\
GL_R_10 & $16(1)$ & 59 & $2(10 ; 55)$ & 100 \\
GL_S_5 & $34(3)$ & 24 & $2(8 ; 19)$ & 100 \\
GL_S_10 & 0 & 0 & 0 & 100 \\
GL_T_5 & $19(1)$ & 39 & $1(38)$ & 0 \\
GL_T_10 & 0 & 2 & 0 & 0 \\
\hline
\end{tabular}

a) If only few individuals are contributing to polymorphisms, the number of individuals is given in brackets. 
According to the cluster analysis from pairwise shared allele-distances with the minimum-variance method, three main clusters were identified for genotyped individuals of Pisarecka Perla (FIGURE 3.13). The largest highly homogenous cluster was named cluster A and contains approximately $60 \%$ of all genotyped individuals. The remaining individuals form two additional clusters (cluster $\mathrm{B}$ and $\mathrm{C}+$ ); one of which is highly homogenous, the other one is heterogeneous to a large degree.

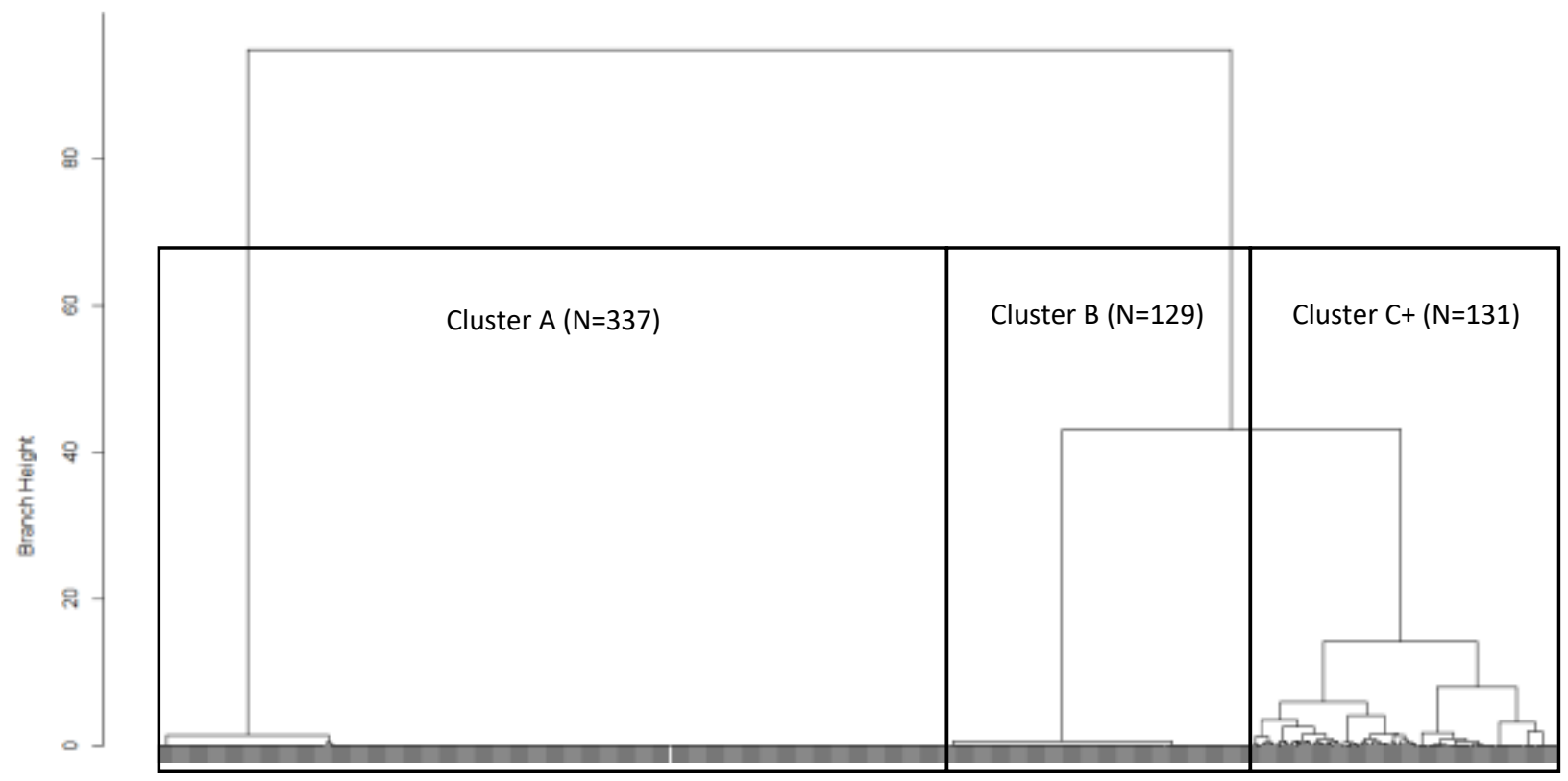

FIGURE 3.13 Minimum-variance-dendrogram (Ward) of all genotyped individuals of Pisarecka Perla.

TABLE 3.12 Number of individuals per population of Pisarecka Perla assigned to the three identified genotypic clusters by the minimum-variance-method.

Cluster

\begin{tabular}{lcccc}
\cline { 2 - 4 } Population & A & B & C+ & Sum \\
\hline PP_0 & 44 & 42 & 14 & 100 \\
\hline PP_R_5 & 68 & 30 & 2 & 100 \\
PP_T_5 & 38 & 32 & 28 & 98 \\
\hline PP_R_10 & 90 & 6 & 4 & 100 \\
PP_S_10 & 66 & 15 & 18 & 99 \\
PP_T_10 & 31 & 4 & 65 & 100 \\
\hline Sum & 337 & 129 & 131 & 597 \\
\hline
\end{tabular}

Subsequent within-population clustering identified three major homogenous genotypes $(A, B, C)$ present in population PP_0 (FIGURE 3.14). Genotypes A, B, and C, correspond to the clusters A, B, and C+ described before. In populations under natural selection after five and ten generations, proportions of the genotypes $A$ and $B$ vary between selection sites and generations, while genotype $C$ is represented by very few samples or not abundant at all in later generations (FIGURE 3.15-3.16). 
Population PP_0 consists of three main genotypes A, B, and C (FIGURE 3.14). Genotype A has 44 homogenous individuals; with one exception for individual PP_0_46 with one heterozygous loci at LcC00019p234 with CT, where all other individuals of the cultivar PP have TT. Genotype B was identified with 42 completely homogenous individuals. Genotype $C$ consists of 11 individuals with one individual (PP_0_79) with an additional locus in heterozygous status with TC at LCC10111p524, where genotype $A$ and $B$ are in homozygous status with TT and CC. Furthermore, locus Contig14652 is in heterozygous status in genotype $C$ with TG, where all other genotypes of population PP_0 have TT. Individuals PP_0_31, PP_0_90, and PP_0_101 could not be assigned to genotype A, B, or C. PP_0_90 is in a different homozygous status for 45 loci compared to PP_0_101 and heterozygous in 5 additional loci, whereas individual PP_0_101 is homozygous in all loci. PP_0_31 is in heterozygous status for 83 loci. Of these 83 loci, 43 loci are polymorphic between genotype $A, B$, and $C, 24$ loci are polymorphic when including PP_0_90 and PP_0_101 as additional genotypes, 8 loci are polymorphic across all individuals genotyped in cultivar PP, and 8 heterozygous loci could neither be found in any individual of cultivar PP nor in cultivar GL, but in cultivar SL the respective allele in homozygous status was found for these 8 SNPs.

FIGURE 3.14 Dendrogram of 100 individuals of population PP_0, analyzed by 147 SNPs and clustered (UPGMA) by their pairwise allele sharing distance (Gao \& Starmer 2007).

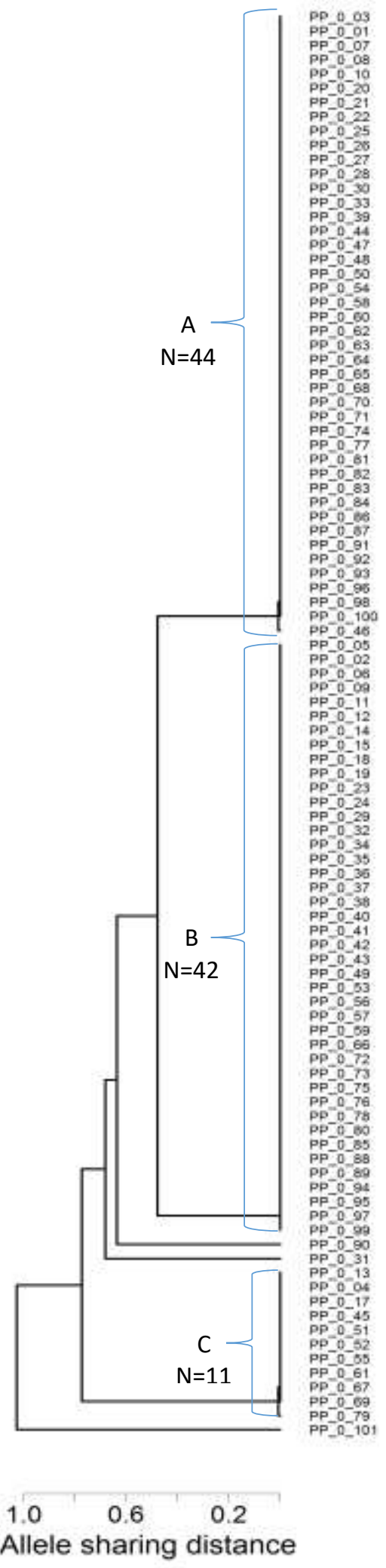


Population PP_R_5 has 68 individuals of genotype $A$ and 30 individuals of genotype $B$ (FIGURE 3.15). Within genotype A, one individual (PP_R_5_96) differs in SNP LCRBContig13114 (TT instead of CC) from all the other individuals. Two individuals, PP_R_5_52 and PP_R_5_95, are heterozygous in 63 and 34 heterozygous loci, respectively. Genotype $C$ is not present in this population.

In population PP_T_5, 38 individuals are assigned to genotype A (FIGURE 3.15). Within genotype A there are three sub-groups: 1.14 individuals are identical to the original genotype $A ; 2.22$ individuals are in a different homozygous status for SNP LCRBContig13114 (TT instead of CC), and two individuals (PP_T_5_01, PP_T_5_34) are heterozygous (TC) at the same locus. Genotype B is present with 32 individuals, which show again sub-grouping for locus LcRBContig13114, with 17 individuals identical to genotype B, 2 individuals in heterozygous status, and 13 individuals in a different homozygous status (CC instead TT). Genotype $\mathrm{C}$ is represented in this population with only one individual identical to the original genotype, except for SNP LCRBContig13114 (PP_T_5_21).

In the $10^{\text {th }}$ generation of population PP_R, genotype $A$ is dominating with 90 individuals, of which 79 are identical for the 147 SNPs, 10 individuals have the other homozygous allele at locus LCRBContig13114, and one individual (PP_R_10_26) is heterozygous at the same locus (FIGURE 3.16). Genotype B is present with 6 individuals. Genotype $C$ is not represented. One individuals is heterozygous at 58 SNP loci (PP_R_10_38).

In population PP_S_10 (FIGURE 3.16), 66 individuals were assigned to genotype A with 44 individuals identical to genotype $A$ and 22 more individuals are closely related with 20 individuals having the opposite homozygous base-pair at locus LCRBContig13114 (TT instead of CC), one heterozygous individual (PP_S_10_85) for the same locus, and one heterozygous individual for 18 additional loci (PP_S_10_74). Genotype B is represented by 12 homogenous individuals plus three closely related individuals. Genotype $C$ is not represented.

The 100 individuals genotyped from population PP_T_10 contain 30 individuals identical or closely related to genotype A (FIGURE 3.16). In fact, 16 individuals are identical, 14 individuals differ at locus LcRBContig13114. Genotype B is represented by four nearly identical individuals. The individual PP_T_10_4 is identical to genotype C. 

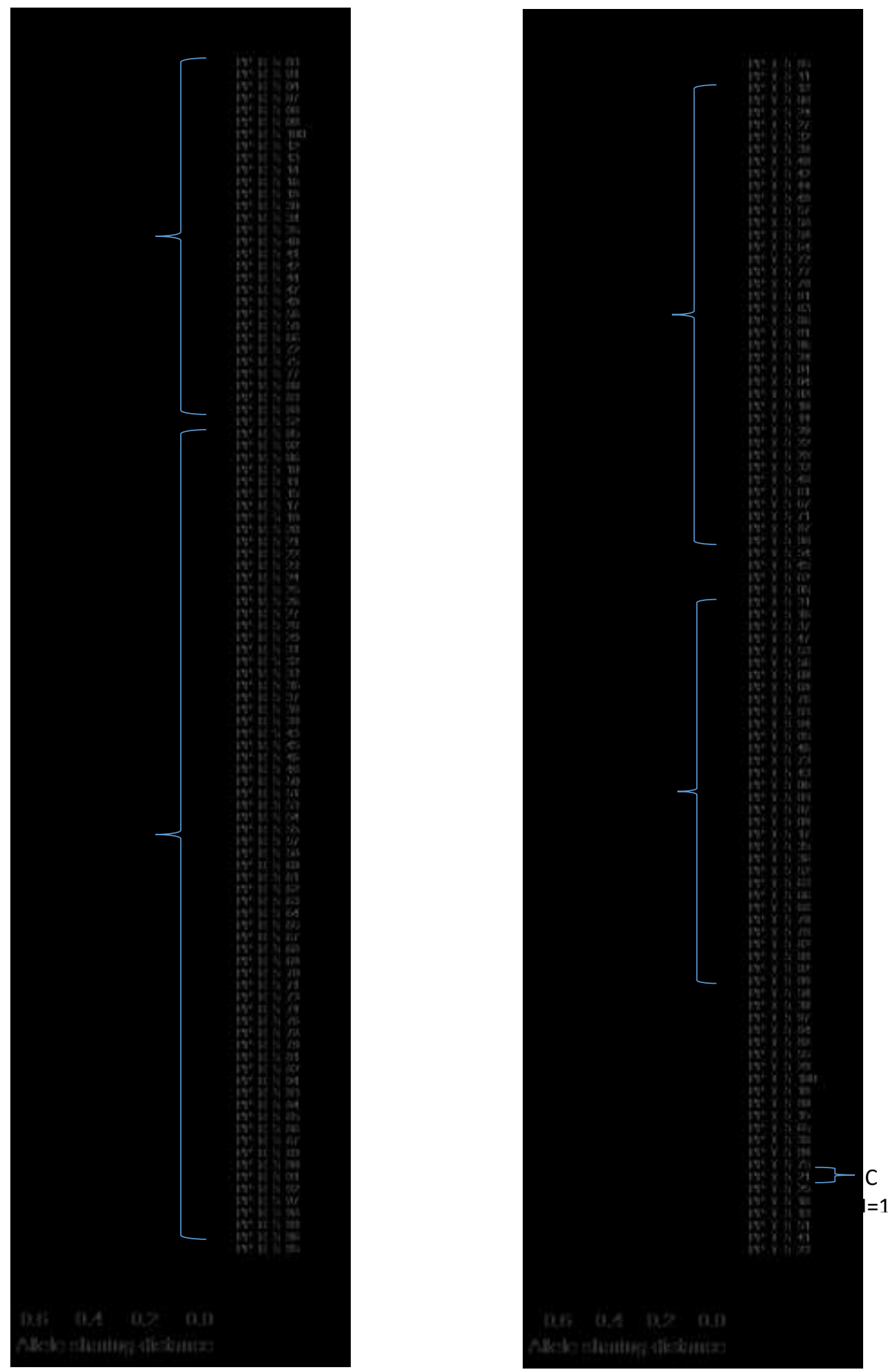

FIGURE 3.15 Hierarchical cluster of 100 individuals of population PP_R_5 (left) and 98 individuals of population PP_T_5 (right) including genotype A, B, and $\mathrm{C}$ as a standard. Cluster analysis was done using the pairwise allele sharing distance (Gao \& Starmer 2007) calculated from 147 SNPs. 


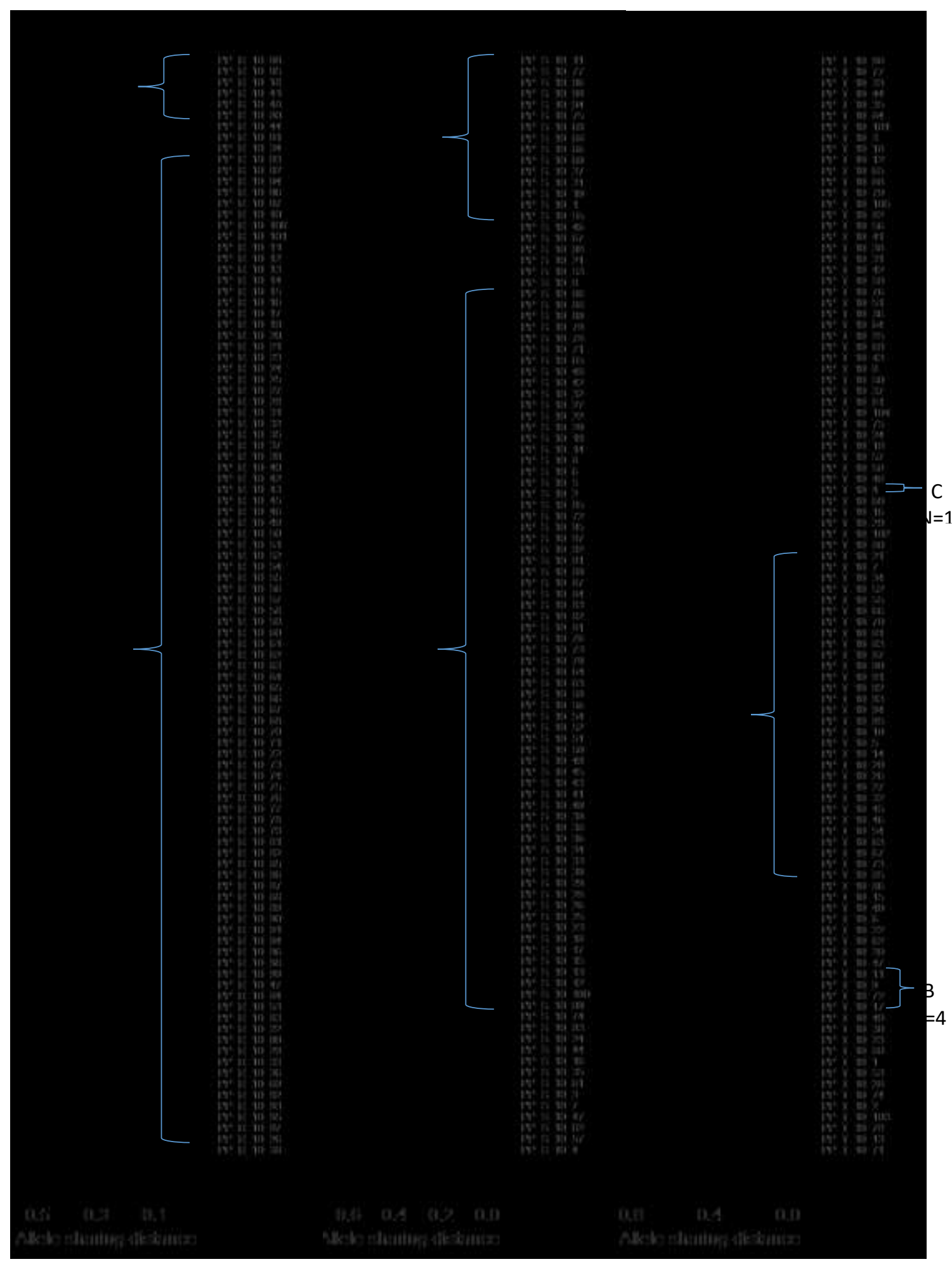

FIGURE 3.16 Hierarchical cluster of 100 individuals of population PP_R_10 (left), 99 individuals of population PP_S_10 (center), and 100 individuals of population PP_T_10 (right) including genotype $A, B$, and $C$ as a standard. Cluster analysis was done using the pairwise allele sharing distance (Gao \& Starmer 2007) calculated from 147 SNPs. 


\section{COMPARISON OF PHENOTYPIC AND GENOTYPIC RESULTS}

According to seed weight and flowering behavior, three morphological groups were observed in the initial population of Pisarecka Perla (FIGURE 3.14). These three phenotypic groups correspond to the three genotypes ( $A, B, C$ ) observed from genotyping (FIGURE 3.17). Genotype $C$ could not be observed anymore in the populations after ten generations of natural selection. In PP_R_10, genotype $A$ became the most abundant with about $90 \%$ of the progenies and 10 progenies are classified to genotype $\mathrm{B}$. Those 10 progenies include the 6 identical genotypes B, except genotype R_08, instead R_81 phenotypically clustered close to $B$ as well as the four genotypes with no clear genotypic affiliation (R_01, $R \_34, R \_38$, R_44).
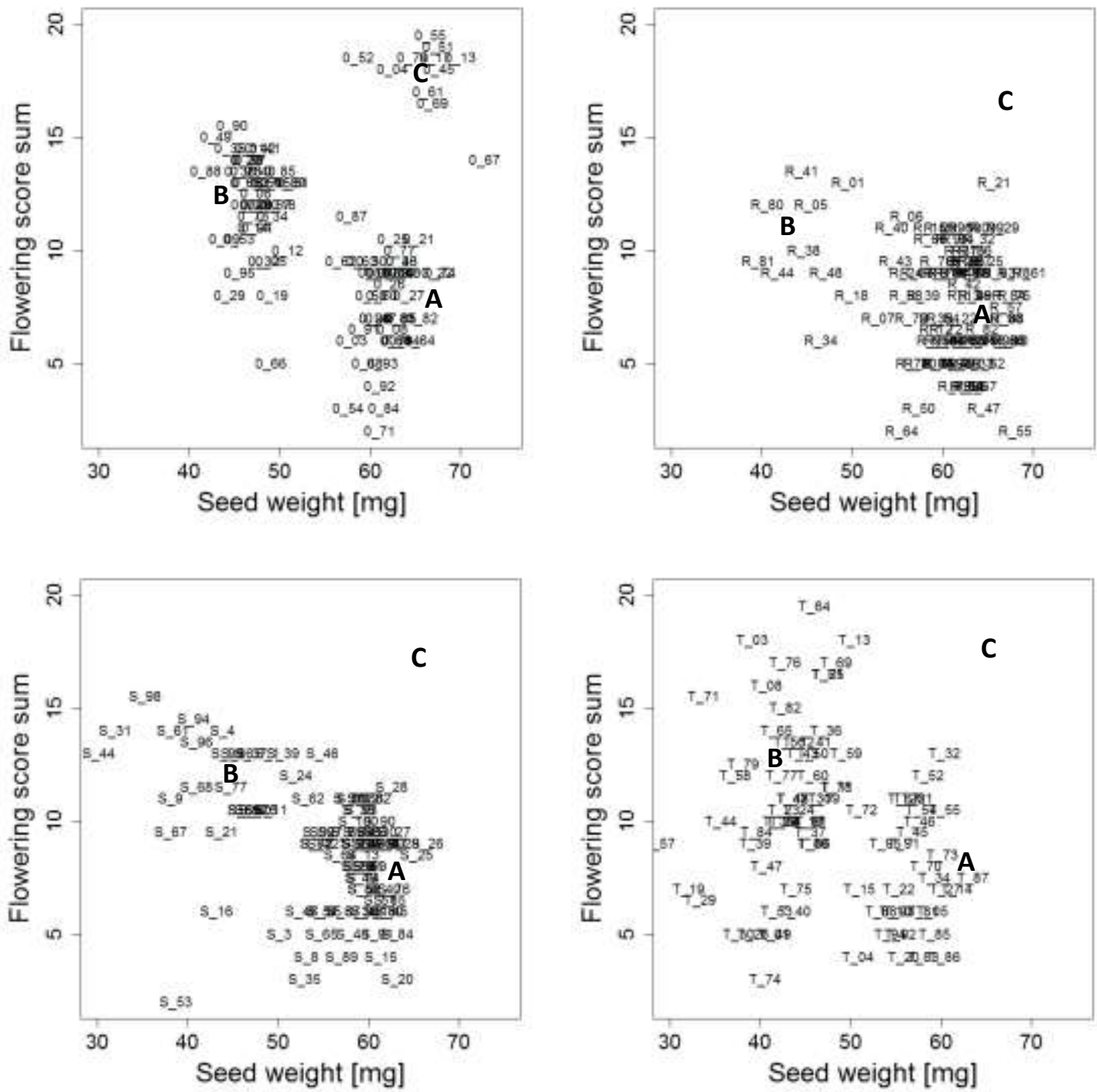

FIGURE 3.17 Scatterplot of flowering score sum over seed weight for individuals of Pisarecka Perla in populations PP_0 (upper left), PP_R_10 (upper right), PP_S_10 (lower left), and PP_T_10 (lower right) phenotyped in 2015. Large letters $A, B$, and $C$ denote approximately the phenotypic mean values of the three genotypes observed in population PP_0. 
One progeny ( $\left.R \_21\right)$ is somewhat outlying from the majority of the genotypes $A$ according to its flowering behavior and slightly closer to the C group mean. In PP_S_10, progenies close to the phenotypic mean of genotype B show a larger variation towards smaller seed size (<40 mg) and one progeny (S_53) is significantly outlying with a very low flowering score sum. In PP_T_10, additional to a large number of progenies with seed weight $<40 \mathrm{mg}$, flowering behavior varies largely for progenies with a seed weight of 30-50 mg.

After genotyping progenies of different populations developed from the cultivar Pisarecka Perla, progenies assigned to genotype $A, B$, and the heterogeneous group $C$ separately for population PP_0, PP_R_10, PP_S_10, and PP_T_10 are plotted in boxplots according to their seed weight and flowering score sum (FIGURE 3.18). Genotype A and B differ significantly and consistently across populations with a few outliers in PP_R_10 and PP_S_10. Group C in PP_0 has the largest mean seed weight with to outlying progenies, whereas in PP_R_10 no significant difference between group $B$ and $C$ according to seed size and flowering behavior is present. In PP_S_10 and PP_T_10, group C is largely variable in seed size and flowering. Mean flowering score sum of progenies in PP_0 differs significantly between genotypic groups.
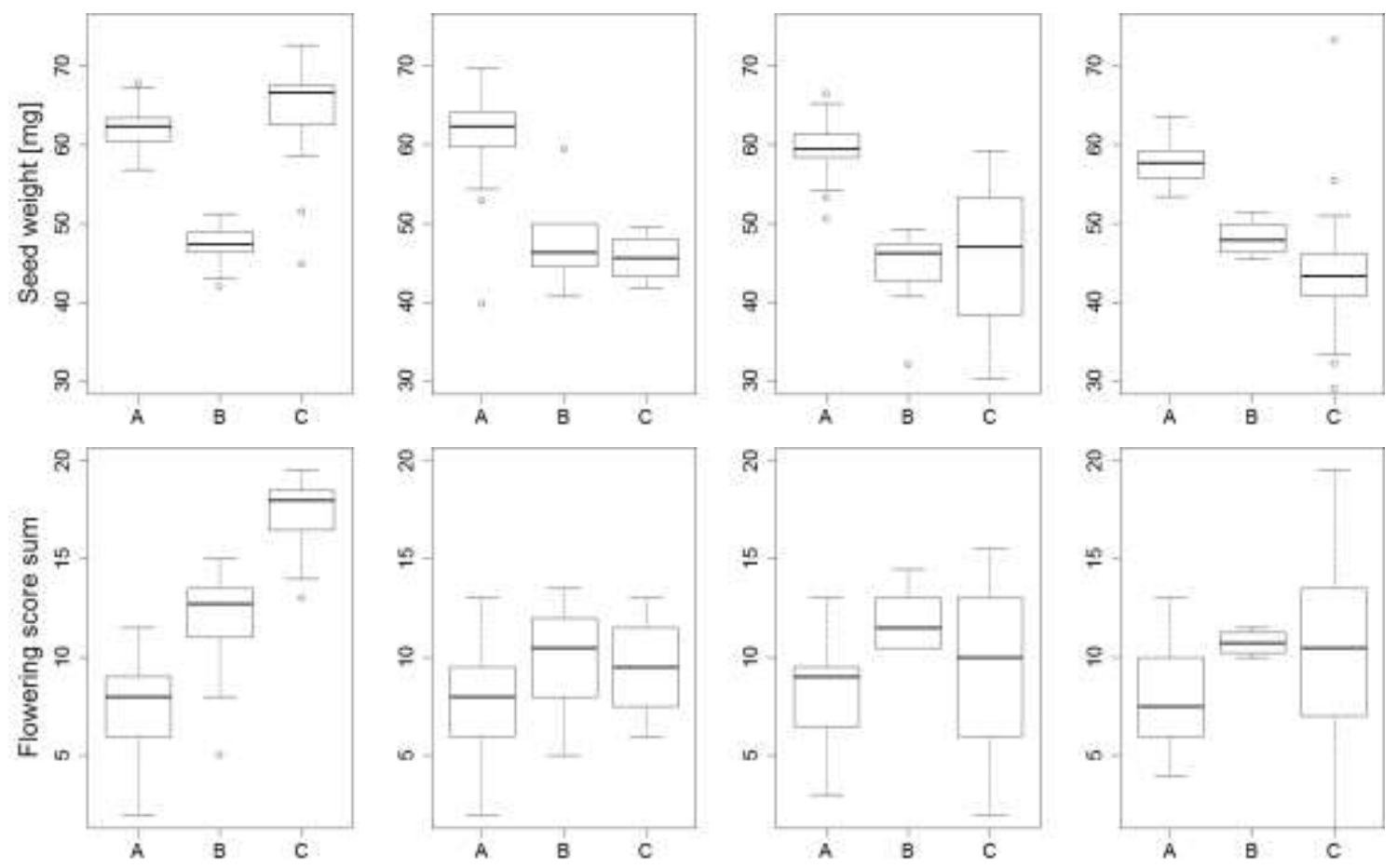

FIGURE 3.18 Boxplots of seed weight (upper) and flowering score sum for progenies of Pisarecka Perla in population PP_0, PP_R_10, PP_S_10, and PP_T_10 (from left to right) separately according to their assignment to genotype $A, B$, or the genotypic heterogeneous group $C$. 


\subsection{Discussion}

The results from field experiments may suffer from the experimental problem of a partially-replicated design and from a severe disease pressure in the second year. Consequently, comparisons between populations in 2015 include possible block effects, e.g. in yield, since spatial environmental variability was not accounted for by the field design. In 2016, the replication of main blocks may have improved the situation. However, various virus diseases had infected the plants severely and thus, despite double rows and more than double the number of seeds sown compared to the first year, seed yield was significantly lower especially in Pisarecka Perla and Schwarze Linse. Straw yield was less affected by the diseases, but also lower for most populations, except populations of Gestreifte Linse. Differences in susceptibility could also be observed between populations within a cultivar.

For seed, straw, and total yield and for seed weight, we observed the largest range, coefficient of variation, and variance within PP_T_10 compared to the other populations of Pisarecka Perla. A certain variability is also visible in flowering, where in PP_0 and PP_T_10 about $15 \%$ and $10 \%$ of the progenies were flowering earlier than any of the progenies in the other populations. At the following scoring dates, a more continuous beginning of flowering is apparent from the frequency plots, with additional $30-40 \%$ more progenies scored flowering with the second and third date of scoring, respectively. Whereas, in PP_R_10 and PP_S_10, a proportion of about $65 \%$ and $50 \%$ of the progenies were scored flowering at the third date in addition to the early flowering progenies scored at the second date.

For Pisarecka Perla a more or less clear grouping in two main groups is visible according to the second principle component mostly influenced by flowering (FTsum) and leaf size (LScan). Because seed weight was found to be significantly correlated with leaf size $(r=0.52)$ and variation between progenies for seed weight within populations of Pisarecka Perla was significant, too, seed weight and flowering turned out to describe the groups best and give the most clear differentiation.

Already from the phenotypic data, a low genotypic diversity could be projected. For Pisarecka Perla, genotypic results correspond clearly to the phenotypic grouping and thus, the SNP markers describe the material accurately. In the case of Schwarze Linse and Gestreifte Linse, outcrossing events possibly have led to the polymorphisms detected in the pre-test and will be further examined and discussed in the following chapter. On the other hand, the very low amount of heterozygous samples confirm a rather low outcrossing rate in these cultivars.

The three groups (or rather genotypes) observed in Pisarecka Perla, correspond with the morphological groups described by Horneburg (2003): Genotype A corresponds to the group of "large seeded, late flowering, with green hypocotyl", genotype B corresponds to the group of "small seeded, earlier flowering, with green hypocotyl", and genotype C corresponds to the group of "large seeded, very early flowering, with red hypocotyl". As discussed in CHAPTER 2.4, environmental conditions at Tangsehl may have favored the small seeded and early flowering genotypes. But additional recombination obviously happened, since genotype $B$ makes up only for $4 \%$ and a large proportion of individuals with red pigmented hypocotyl was observed (34.2 - 45.8\%, TABLE 2.12). According to seed color and size and the genotypic results, we expect a higher probability that such recombination events occurred within Pisarecka Perla, e.g. with genotype $C$ as the donor of the red hypocotyl. In an earlier study, outcrossing rates for Pisarecka Perla have been shown to reach in extreme individual plants up to $22.2 \%$ and was observed more frequently at Reinshof 
compared to Schönhagen (Horneburg 2006). Outcrossing rates were not estimated for Tangsehl, however, significant influence of environmental conditions of year and location was observed in the same study. The number of samples with more than $5 \%$ heterozygous loci within populations under natural selection in Tangsehl (TABLE 3.11) suggest that recombination occurs on a regular basis, but with a low frequency. Thus, we find samples with 8-71 heterozygous loci (5-48\%), but out of the $12 \%$ heterozygous samples $(\mathrm{H}>5 \%)$ in generation five, only six samples are highly heterozygous with $22-48 \%$ heterozygous loci.

A clear site-specific development is visible for Pisarecka Perla. Whereas one genotype is dominating the population developed at Reinshof, probably within-population recombination by outcrossing resulted in a relatively diverse small seeded population at Tangsehl despite the expected high selection pressure due to more 'stress-prone' conditions.

Temporal development may be caused by a combination of natural selection, drift, and rare events of outcrossing and recombination. During the long-term experiment, drift may have played a role as discussed by Horneburg and Becker (2008) during the early stage, when only 30-100 seeds per location and cultivar were sown. Significant bottlenecks also occurred already during ex situ maintenance as Horneburg (2003) documented. During 2001-2006 when seeds were stored, a significantly reduction in germination capacity was observed in a germination test with 200 seeds in four replication for Pisarecka Perla populations selected at Schönhagen and Reinshof with only about $14 \%$ germination, which was significantly lower compared to the 'Tangsehl selection' with $59 \%$. Germination of Schwarze Linse and Gestreifte Linse was still relatively high with 73.5 - $99 \%$. Thus, if the loss in germination capacity was genotype dependent, the reduction in genotypic variation within the Reinshof and Schönhagen populations may have been also influenced by 'selection' on seed longevity. On the other hand, for seed weight and flowering, we observed a continuous development at Reinshof and Tangsehl comparing the fifth and the tenth generation with the initial material, suggesting directional site-specific natural selection.

In conclusion, we observe a significant site-specific development for populations from one cultivar. For the maintenance of plant genetic resources, on-farm management leads to a dynamic development and diverse locations are necessary to maintain diversity. 


\section{REFERENCES}

Allard RW, Kahler AL, Weir BS (1972) The effect of selection on esterase allozymes in a barley population. Genetics 72:489-503.

Becker HC (2011) Pflanzenzüchtung, 2nd edn. Eugen Ulmer KG, Stuttgart (Hohenheim).

Enjalbert J, Goldringer I, Paillard S, Brabant P (1999) Molecular markers to study genetic drift and selection in wheat populations. Journal of Experimental Botany 50:283-290. doi:10.1093/jexbot/50.332.283.

Erskine W, Isawi J, Masoud K (1990) Single plant selection for yield in lentil. Euphytica 48:113-116.

Fedoruk MJ (2013) Linkage and association mapping of seed size and shape in lentil. M. Sc. Thesis, Saskatoon, Saskatchewan.

Fedoruk MJ, Vandenberg A, Bett KE (2013) Quantitative Trait Loci Analysis of Seed Quality Characteristics in Lentil using Single Nucleotide Polymorphism Markers. The Plant Genome 6:0. doi:10.3835/plantgenome2013.05.0012.

Galili T (2015) dendextend: an R package for visualizing, adjusting and comparing trees of hierarchical clustering. Bioinformatics (Oxford, England) 31:3718-3720. doi:10.1093/bioinformatics/btv428.

Gao X, Starmer JD (2008) AWclust: point-and-click software for non-parametric population structure analysis. BMC bioinformatics 9:77. doi:10.1186/1471-2105-9-77.

Hagenblad J, Boström E, Nygårds L, Leino MW (2014) Genetic diversity in local cultivars of garden pea (Pisum sativum L.) conserved 'on farm' and in historical collections. Genetic Resources and Crop Evolution 61:413-422. doi:10.1007/s10722-013-0046-5.

Horneburg B (2003) Standortspezifische Sortenentwicklung: Eine Studie mit Landsorten der Linse. Schriften zu Genetischen Ressourcen. Band 21.

Horneburg B (2006) Outcrossing in lentil (Lens culinaris) depends on cultivar, location and year, and varies within cultivars. Plant Breeding 125:638-640.

Horneburg B, Becker HC (2008) Crop Adaptation in On-Farm Management by Natural and Conscious Selection. A Case Study with Lentil. Crop Science 48:203-212.

Husson F, Josse J, Lê S, Mazet J (2009) FactoMineR: Multivariate Exploratory Data Analysis and Data Mining with R. R package version 1.12, URL http://factominer.free.fr/.

Leino MW, Bostrom E, Hagenblad J (2013) Twentieth-century changes in the genetic composition of Swedish field pea metapopulations. Heredity 110:338-346. doi:10.1038/hdy.2012.93.

Lombardi M, Materne M, Cogan NOI, Rodda M, Daetwyler HD, Slater AT, Forster JW, Kaur S (2014) Assessment of genetic variation within a global collection of lentil (Lens culinaris Medik.) cultivars and landraces using SNP markers. BMC genetics 15:1-10. doi:10.1186/s12863-014-0150-3.

RStudio Team (2015) RStudio: Integrated Development for R. RStudio, Inc., Boston, MA URL http://www.rstudio.com/.

Schoen DJ, Brown AHD (1991) Intraspecific variation in population gene diversity and effective population size correlates with the mating system in plants. Proc. Natl. Acad. Sc. 88:4494-4497. 
Semagn K, Babu R, Hearne S, Olsen M (2014) Single nucleotide polymorphism genotyping using Kompetitive Allele Specific PCR (KASP). Overview of the technology and its application in crop improvement. Molecular Breeding 33:1-14. doi:10.1007/s11032-013-9917-x.

Sharpe AG, Ramsay L, Sanderson L, Fedoruk MJ, Clarke WE, Li R, Kagale S, Vijayan P, Vandenberg A, Bett KE (2013) Ancient orphan crop joins modern era: gene-based SNP discovery and mapping in lentil. BMC genomics 14:1-13. doi:10.1186/1471-2164-14-192.

Sokal RR, Michener CD (1958) A statistical method for evaluating systematic relationships. University of Kansas Science Bulletin 38:1409-1438.

Tibshirani R, Walther G, Hastie T (2001) Estimating the number of clusters in a data set via the gap statistic. Journal of the Royal Statistical Society: Series B (Statistical Methodology) 63:411-423. doi:10.1111/1467-9868.00293.

Tiranti B, Negri V (2007) Selective microenvironmental effects play a role in shaping genetic diversity and structure in a Phaseolus vulgaris L. landrace: implications for on-farm conservation. Molecular ecology 16:4942-4955. doi:10.1111/j.1365-294X.2007.03566.x.

Toklu F, Karaköy T, Haklı E, Bicer T, Brandolini A, Kilian B, Özkan H (2009) Genetic variation among lentil ( Lens culinaris Medik) landraces from Southeast Turkey. Plant Breeding 128:178-186. doi:10.1111/j.1439-0523.2008.01548.x.

Utz HF (2011) PLABSTAT. Software for the statistical analysis of experiments in the area of plant breeding. Institut of Plant Breeding, Seed Science and Populations Genetics, Universität Hohenheim, Hohenheim.

Ward JH (1963) Hierarchical grouping to optimize an objective function. American Statistical Association Journal 426:236-244.

Ward JH, Hook ME (1963) Application of an hierarchical grouping procedure to a problem of grouping profiles. Educational and Psychological Measurement 23:69-81.

Zhong Y (2017, unpublished) Phenotypic and molecular variation in lentil populations selected for extreme seed size. M.Sc. Thesis, Georg-August-Universität, Göttingen. 


\section{Performance AND WITHIN-POPULATION VARIATION OF SELECTIONS FOR EXTREME SEED SIZE}

\subsection{INTRODUCTION}

The importance of seed size is widely discussed in terms of its correlation to yield (Erskine 1996) and fitness related traits (Al-Karaki 1998; Eriksson 1999; Hojjat 2011) and concerning its significance for adaptation by natural selection (Silvertown 1989; Haig 1989; Coomes and Grubb 2003; Sadras 2007). During on-farm management of plant genetic resources, seed size may be a trait that could be relatively easily selected for during cleaning of seed lots. Beside seed color, seed size is also an important quality trait that may be important in the cultural background and traditional use of a landrace or cultivar and is important for industrial processing and the end uses, as cooking time is strongly correlated with seed size and weight (Erskine et al. 1985; Hamdi et al. 1991).

During long-term experiments, seed weight was observed to be altered by natural selection, depending on environmental conditions and is not necessarily changing towards lower seed weight (Goldringer et al. 2001; Horneburg 2003; Horneburg and Becker 2008).

In preparation of this study, selection in both directions for large and small seeds was conducted in three old cultivars (see CHAPTER 1.1) during six generations. Separation by sieving of larger seeds from smaller seeds was started from the seed lot harvested in 1999 and the largest and smallest fractions of the seeds were subsequently tested in field plots in 2000 by Horneburg (2003). In the large seeded cultivar Pisarecka Perla, seeds could be separated resulting in statistically significantly different fractions of seed weight and during the field test significant variation between selections for begin of flowering, straw yield, and harvest index was observed. Beginning of flowering was also observed earlier in the large seeded fraction of Schwarze Linse, but seed size fractions were not significantly different in seed weight for Schwarze Linse and for Gestreifte Linse.

Results from a B. Sc. thesis by Halekotte (2015, unpublished) in our material from potted plants in the greenhouse suggest a strong interaction of the effect of seed size on germination and young plant development with the cultivar. Comparing seedling development from small and large seeds, faster development from larger seeds was observed during earlier stages in Schwarze Linse, whereas the large seeds of Pisarecka Perla showed faster development in later stages compared to the small seeded selections of the respective cultivar. This may be due to the cultivar specific growth type (erect growth with a lower number and less strong side-branches versus considerably strong branches and a half erect growth) and an associated cultivar specific competition strategy. Gestreifte Linse, with a medium seed size and significant branching and an overhanging growth, was observed to have the lowest seedling height compared to the other cultivars, but it had the highest number of side branches, followed by Pisarecka Perla and Schwarze Linse with the lowest number of side branches. Differences between selections of Gestreifte Linse were not observed from these data during a single greenhouse-season experiment.

Genetic linkage and association mapping of seed size parameters in lentil were done by Fedoruk (2013) and Fedoruk et al. (2013) using SNP assays developed by Sharpe et al. (2013). In our project during a pretest in the M.Sc. thesis of Zhong (2017, unpublished), we used the same SNP assays and selected 145 SNPs 
that have been polymorphic for our material. Zhong identified 18 SNPs which were more or less specifically differentiating between large and small seed fractions within cultivars. However, alleles of many of these polymorphic markers were observed to be cultivar-specific, thus, not always explicitly identifying 'large seed' across cultivars.

In this chapter, we evaluate the field performance of the specific selections for extreme seed size at the three farms in comparison with the initial material and populations developed by site-specific natural selection. Additionally, we examine phenotypic and genetic variability within the selections by single-plant progeny testing and genotyping. Three main aspects are pursued in this chapter: i) What is the impact of selection for seed size compared to the initial material? ii) What is the importance of seed weight for sitespecific adaptation? and iii) How did selection for seed size influence the genetic variability? 


\subsection{Materials AND MethodS}

\section{PLANT Genetic MAterials}

The plant genetic material tested in field plots was developed and selected during six generations by sieving to select the largest and smallest seeded fraction after each regeneration (see CHAPTER 1.1). For the first time, sieving was done from the seed lot harvested in 1999 and subsequent regeneration took place at Reinshof in 2000. Selection by sieving and regeneration was repeated during 2006-2010 at Reinshof. To obtain good seed quality for the experiments in this study, selections were multiplied in a rainout shelter in 2014 (see CHAPTER 2.2).

Seeds from single plants were produced in the green house during winter 2014/15 to conduct single-plantprogeny test trials with 100 progenies tested in 2015 and repeated for 50 progenies in 2016, as described in CHAPTER 3.2.

\section{LOCATIONS AND CLIMATIC CONDITIONS}

Selections were tested in field plots at Reinshof, Schönhagen, and Tangsehl. Single-plant-progeny testing took place at Reinshof. All experiments were conducted during 2015 and 2016. For soil and climatic conditions at the locations see CHAPTER 2.2.

\section{Phenotyping}

Agronomic, morphological, and phenological traits were assessed from the field plots at three locations as described in CHAPTER 2.2. Phenotyping of single-plant-progenies was done as described in CHAPTER 3.2.

\section{GENOTYPING}

As a pre-test of all available SNP marker assays at LGC Genomics, 16 progenies of each selection, representing the smallest or largest seed weight according to the results from the greenhouse regeneration, were selected and genotyped from DNA of one single seed (see also description in CHAPTER 3.2). The results were evaluated in the M. Sc. Thesis by Zhong (2017, unpublished) and from her results, 145 selected SNPs were used for genotyping of 24 more progenies in 2016 from DNA extracted from a single seed per progeny from the field plots in 2015. 


\section{STATISTICAL ANALYSIS}

Multi-location field data was evaluated by the analysis of variance (ANOVA) in PLABSTAT (Version 3Bwin, Utz 2011) and mean values were calculated in the same software. The following general model was applied:

$x_{i j k l m}=\mu+y_{i}+r_{m}+l_{j}+y\left|r_{i j m}+c_{k}+y l c r_{i j k m}+s_{l}+y l c s r_{i j k l m}+y l_{i j}+y c_{i k}+\right| c_{j k}+y p_{i l}+\mid p_{j l}+c p_{k l}+y l c_{i j k}+y l p_{i j l}$ where $x_{i j k l m}$ is the observed value, $\mu$ is the general mean of the experiment, and $y_{i}, l_{j}, c_{k}, p_{1}$, and $r_{m}$ are the effects of year, location, cultivar, selection, and replication, respectively. The replication is a random factor within year, location, and cultivar. Possible interactions are considered up to the three-way level $\left(\mathrm{yl} \mathrm{lij}_{\mathrm{ij}} \mathrm{y} \mathrm{y}_{\mathrm{ik}}\right.$, $\left.\left|c_{j k}, y p_{i l},\right| p_{j l}, c p_{k l}, y\left|c_{i j k}, y\right| p_{i j l}\right)$ and the residual error is denoted by $y \mid c s r_{i j k l m}$.

The model is reduced by the factors 'location' and 'cultivar' for the site-specific analysis and comparison between selections and populations in generation 0 and 10 (see CHAPTER 2) separately per cultivar and location.

Post-hoc mean comparisons were done by Tukey's HSD (honestly significant difference) test. The HSD values were calculated 'by hand' in Microsoft Excel (Version 2010) using the mean squares and degrees of freedoms (or alternatively the standard errors) given in the ANOVA table by PLABSTAT and the respective $q$-value from the 'Studentized $Q$ table' for a level of significance of $5 \%(P=0.05)$; in few cases for $10 \%$ $(P=0.1)$.

Phenotypic data from the progeny testing trials at Reinshof were analysis as described in CHAPTER 3.2.

Genotypic data were analyzed (as described in CHAPTER 3.2) with the software 'AWclust' written for R with a GUI interface (Gao and Starmer 2008). It uses the 'allele sharing distance' (ASD) and then applies 'Ward'sminimum-variance' criterion (Ward 1963; Ward and Hook 1963) directly to the similarity matrix. And for the analysis within cultivars to compare individuals of the two selections, the ASD matrix calculated from AWclust was exported and used for the cluster analysis by the 'Unweighted Pair Group Method with Arithmetic mean' (UPGMA; Sokal and Michener 1958) in RStudio using the functions 'hclust()' and 'plot(as.dendrogram())' from the package 'Dendextend' by Galili (2015). 


\subsection{RESULTS}

\section{PHENOTYPIC RESULTS}

\section{PERFORMANCE TRIALS}

From the performance trials during 2015 and 2016 at three locations, selections for small and large seeds and the population in generation 0 are compared across years and test locations and significant variation in all traits for cultivar SL was observed; within cultivars PP and GL significant variation was found in seed weight, flowering, and either straw yield or seed yield within one of the cultivars, respectively (TABLE 4.1). Comparisons of mean values between the three test entries "large", "small", and generation 0 are shown in TABLE 4.2. Significant differences between means across year and test locations are found for straw yield between PP_small and PP_large with the highest yield for the large seeded selection compared to the two other test entries. Seed weight comparisons within PP are significant between all three test entries with a seed weight mean for generation 0 laying in between the selections with about $4 \mathrm{mg}$ (Tukey's-HSD value $=1.744 \mathrm{mg}$ for $\mathrm{P}=0.05$ ) more than the mean of both selections. Flowering within PP was observed significantly earlier in the large selection and in generation 0 compared to the small selection. The large seeded selection of cultivar SL yielded significantly more and had a larger harvest index and seed weight compared to the small seeded selection and generation 0 . Scores for ripening and the sum of scores for flowering are significantly lower in SL_large compared to SL_small, meaning later flowering and ripening. Selections of Gestreifte Linse show significant variation in seed yield, seed weight, and flowering. Seed yield and seed weight was significantly higher in GL_large compared to GL_small, but not significantly different from GL_0. Flowering was scored significantly later in GL_large compared to GL_small. 
TABLE 4.1 Variance components from ANOVA for the main effects year, location, selection, replication (error variance for year and location), and residual (error variance for selection) with their significance in the F-test ${ }^{\mathrm{a}}$, and heritability values $\left(\mathrm{h}^{2}\right)$ for selections within cultivars including generation 0 and selections for large and small seeds.

\begin{tabular}{|c|c|c|c|c|c|c|c|}
\hline Trait & Cultivar & $\begin{array}{l}\text { Year } \\
(D F=1)\end{array}$ & $\begin{array}{c}\text { Location } \\
(\mathrm{DF}=2)\end{array}$ & $\begin{array}{c}\text { Selection } \\
(D F=2)\end{array}$ & $\begin{array}{c}\text { Replication } \\
(\mathrm{DF}=3)\end{array}$ & $\begin{array}{c}\text { Residual } \\
(\mathrm{DF}=48)\end{array}$ & $h^{2}$ \\
\hline \multirow[t]{3}{*}{ Seed yield } & PP & 994 & $4512 * *$ & $0^{b)}$ & 342 & 4979 & 0 \\
\hline & SL & $3094 * *$ & $8192 * *$ & $297 * *$ & $254 * *$ & 408 & 94.6 \\
\hline & GL & $1605^{* *}$ & $14299 * *$ & $139 * *$ & 0 & 679 & 83.1 \\
\hline \multirow[t]{3}{*}{ Straw yield } & PP & $4807^{* *}$ & $31311^{* *}$ & $270 * *$ & $393 * *$ & 695 & 90.3 \\
\hline & SL & $6739 * *$ & $30478 * *$ & $706 * *$ & $229 * *$ & 601 & 96.6 \\
\hline & GL & $1645^{+}$ & $33990 * *$ & 0 & 0 & 13592 & 0 \\
\hline \multirow[t]{3}{*}{ Total yield } & PP & 10489* & $59782 * *$ & 337 & $1449 *$ & 6748 & 54.5 \\
\hline & SL & $19005^{* *}$ & $70206 * *$ & $1941 * *$ & $908 * *$ & 1522 & 96.8 \\
\hline & GL & $6834^{*}$ & $92767^{* *}$ & 67.9 & 0 & 14726 & 10.0 \\
\hline \multirow[t]{3}{*}{ Harvest index } & PP & 1.68 & $25.8^{* *}$ & 0.71 & 0 & 45.5 & 27.1 \\
\hline & SL & 0 & $8.06 * *$ & $1.20 * *$ & $1.81^{*}$ & 6.33 & 82.0 \\
\hline & GL & 3.66 & $13.4^{*}$ & 1.43 & 1.77 & 80.8 & 29.8 \\
\hline \multirow[t]{3}{*}{ Seed weight } & PP & $0.95 *$ & $6.56^{* *}$ & $115^{* *}$ & 0 & 6.25 & 99.8 \\
\hline & SL & 0 & $0.64^{* *}$ & $29.2^{* *}$ & $0.23^{+}$ & 1.25 & 99.8 \\
\hline & GL & 0.03 & $0.99 * *$ & $41.9 * *$ & 0 & 0.94 & 99.9 \\
\hline \multirow{3}{*}{$\begin{array}{l}\text { Flowering } \\
\text { score sum }\end{array}$} & PP & $9.05 * *$ & $4.58^{* *}$ & $1.54^{* *}$ & 0.21 & 1.83 & 95.3 \\
\hline & SL & $12.4^{* *}$ & $6.97^{* *}$ & $0.19 *$ & $0.64^{* *}$ & 1.65 & 73.5 \\
\hline & GL & $36.2^{* *}$ & $5.70 * *$ & $0.11^{*}$ & $0.18^{*}$ & 0.83 & 76.9 \\
\hline \multirow{3}{*}{$\begin{array}{l}\text { Ripening } \\
\text { score }\end{array}$} & PP & $0.39 * *$ & $1.20 * *$ & $0.04^{+}$ & 0 & 0.46 & 67.1 \\
\hline & SL & $0.34^{*}$ & $1.71^{* *}$ & $0.04^{*}$ & 0.03 & 0.43 & 69.6 \\
\hline & GL & 0.08 & $1.26^{* *}$ & 0 & 0.20 & 0.22 & 0 \\
\hline
\end{tabular}

a) Significance levels are denoted with $* *, *,+$ for P-values $=0.01,0.05,0.1$, respectively.

a) Negative estimates.

TABLE 4.2 Mean values for seed yield (KY), straw yield (SY), total yield (TY), harvest index (HI), seed weight (SW), ripening scores (RP), and flowering scores sum (FTsum) across years and locations for selections for large and small seeds and the initial population (0) of the three cultivars (PP, SL, GL).

\begin{tabular}{lccccccc}
\hline Selection & KY $\left[\mathrm{gm}^{-2}\right]$ & SY $\left[\mathrm{gm}^{-2}\right]$ & TY $\left[\mathrm{gm}^{-2}\right]$ & HI & SW $[\mathrm{mg}]$ & RP & FTsum \\
\hline PP_large & 143.6 & $256.0 \mathrm{~b}^{\mathrm{a})}$ & 399.5 & 36.1 & $64.5 \mathrm{c}$ & 5.6 & $14.0 \mathrm{~b}$ \\
PP_small & 133.4 & $227.3 \mathrm{a}$ & 360.7 & 39.3 & $43.6 \mathrm{a}$ & 6.0 & $11.8 \mathrm{a}$ \\
PP_0 & 128.4 & $224.8 \mathrm{a}$ & 353.2 & 38.0 & $58.3 \mathrm{~b}$ & 5.9 & $13.9 \mathrm{~b}$ \\
\hline \multicolumn{1}{c}{ Mean } & 135.1 & 236.0 & 371.1 & 37.8 & 55.5 & 5.8 & 13.2 \\
\hline SL_large & $158.1 \mathrm{~b}$ & $254.1 \mathrm{~b}$ & $412.2 \mathrm{~b}$ & $40.8 \mathrm{~b}$ & $32.8 \mathrm{~b}$ & $6.0 \mathrm{a}$ & $13.5 \mathrm{a}$ \\
SL_Small & $125.2 \mathrm{a}$ & $204.7 \mathrm{a}$ & $329.8 \mathrm{a}$ & $38.7 \mathrm{a}$ & $23.2 \mathrm{a}$ & $6.5 \mathrm{~b}$ & $14.4 \mathrm{~b}$ \\
SL_0 & $130.3 \mathrm{a}$ & $210.3 \mathrm{a}$ & $340.5 \mathrm{a}$ & $38.7 \mathrm{a}$ & $23.7 \mathrm{a}$ & $6.3 \mathrm{ab}$ & $13.6 \mathrm{ab}$ \\
\hline \multicolumn{1}{c}{ Mean } & 137.8 & 223.0 & 360.8 & 39.4 & 26.5 & 6.3 & 13.8 \\
\hline GL_large & $198.9 \mathrm{~b}$ & 262.8 & 461.7 & 47.4 & $36.6 \mathrm{~b}$ & 6.3 & $7.2 \mathrm{a}$ \\
GL_small & $173.3 \mathrm{a}$ & 252.6 & 425.9 & 43.3 & $25.2 \mathrm{a}$ & 6.4 & $7.9 \mathrm{~b}$ \\
GL_0 & $189.2 \mathrm{ab}$ & 287.6 & 476.7 & 43.9 & $36.1 \mathrm{~b}$ & 6.4 & $7.6 \mathrm{ab}$ \\
\hline \multicolumn{1}{c}{ Mean } & 187.1 & 267.7 & 454.8 & 44.9 & 32.6 & 6.4 & 7.6 \\
\hline
\end{tabular}

a) Mean values followed by the same letter column-wise are not significantly different in Tukey's-HSD test at $P=0.05$. 
In TABLE 4.3, TABLE 4.4, and TABLE 4.5, the performance at each individual test location is compared between the large and the small seeded selections, the initial population, and the respective site-specific population in the $10^{\text {th }}$ generation under natural selection from the same location.

In Pisarecka Perla at Reinshof the large seeded selection differs significantly for straw yield and harvest index from the initial population, but not from any of the other selections/populations. The seed weight of PP_large at Reinshof is similar to that of PP_R_10 and significantly different in all other comparisons. Flowering time is earliest in PP_large and latest in PP_R_10 and differs significantly for all comparisons. Leaf size is significantly smaller in PP_small compared to all other selections/populations. In Schönhagen, both small and large seeded selections differ significantly for seed size from PP_S_10. Flowering is again earlier for PP_large, but not significantly different compared to PP_S_10. In Tangsehl yield traits did not differ significantly between populations or selections. All comparisons were significant for seed weight. Flowering was earliest for PP_T_10.

The large seeded selection of Schwarze Linse at Reinshof had the highest yield, which was significant compared to SL_small and SL_0 for seed and total yield. Seed weight and leaf size is significantly higher for SL_large, compared to the other selections/populations. Flowering is earliest in SL_R_10 and significantly different from SL_0 and SL_large. In Schönhagen, yield and seed weight are significantly higher for SL_large compared to all other selections/populations. Eeliest flowering was observed for SL_S_10, which was significant in comparison with SL_0. In Tangsehl, again SL_large is the highest yielding selection. Additionally, the harvest index was significantly higher for the same selection, as well as the seed weight. Flowering was significantly later for SL_large compared to all other selections/populations.

Comparisons within Gestreifte Linse at Reinshof reveal significant differences for straw and total yield between GL_large and GL_small, with the lowest yield for the latter and the highest for GL_large. Seed weight and leaf size are significantly lower for the small seeded selection. In Schönhagen, significant comparisons were found for seed weight and flowering only, with the lowest seed weight and the earliest flowering for the small seeded selection. In Tangsehl, seed yield for the small seeded selection was significantly lower, whereas straw yield was highest (non-significant) for the same selection. 
TABLE 4.3 Mean values at Reinshof for seed yield (KY), straw yield (SY), total yield (TY), harvest index (HI), seed weight (SW), ripening scores (RP), flowering scores sum (FTsum), and leaf size (LS) across years for selections for large and small seeds, the initial population (0), and the population under natural selection in the $10^{\text {th }}$ generation from Reinsh of for each cultivar (PP, SL, GL).

\begin{tabular}{|c|c|c|c|c|c|c|c|c|}
\hline Selection & $\mathbf{K Y}\left[\mathrm{gm}^{-2}\right]$ & SY $\left[\mathrm{gm}^{-2}\right]$ & TY $\left[\mathrm{gm}^{-2}\right]$ & HI & SW [mg] & RP & FTsum & LS $\left[\mathrm{cm}^{2}\right]$ \\
\hline PP_large & 207.2 & $465.8 b^{a)}$ & 673.0 & $30.6 \mathrm{a}$ & $62.6 \mathrm{c}$ & 6.4 & $13.6 \mathrm{~d}$ & $14.7 \mathrm{~b}$ \\
\hline PP_small & 205.9 & $422.8 \mathrm{ab}$ & 628.7 & $32.1 \mathrm{ab}$ & $40.0 \mathrm{a}$ & 6.7 & $9.2 \mathrm{~b}$ & $11.9 \mathrm{a}$ \\
\hline PP_0 & 229.7 & 417.1 a & 646.8 & $35.3 \mathrm{~b}$ & 54.7 b & 6.9 & $12.4 \mathrm{c}$ & $13.9 \mathrm{~b}$ \\
\hline PP_R_10 & 203.6 & $451.1 \mathrm{ab}$ & 654.6 & $30.8 \mathrm{a}$ & $60.0 \mathrm{c}$ & 6.3 & $7.6 \mathrm{a}$ & $15.2 \mathrm{~b}$ \\
\hline Mean & 211.6 & 439.2 & 650.8 & 32.2 & 54.3 & 6.6 & 10.7 & 13.9 \\
\hline SL_large & 250.1 & $469.8 \mathrm{~b}$ & $719.9 \mathrm{~b}$ & 34.5 & $31.6 \mathrm{~b}$ & $6.3 \mathrm{a}$ & $12.3 \mathrm{a}$ & $12.4 \mathrm{~b}$ \\
\hline SL_small & 228.4 & 392.7 a & $621.1 \mathrm{a}$ & 36.7 & $22.6 \mathrm{a}$ & $7.2 \mathrm{~b}$ & $12.8 \mathrm{ab}$ & $9.3 \mathrm{a}$ \\
\hline SL_0 & 237.7 & $400.4 \mathrm{a}$ & $638.1 \mathrm{a}$ & 37.0 & $23.0 \mathrm{a}$ & $6.8 \mathrm{ab}$ & $11.9 \mathrm{a}$ & $9.1 \mathrm{a}$ \\
\hline SL_R_10 & 232.1 & $432.0 \mathrm{ab}$ & $664.1 \mathrm{ab}$ & 35.1 & $22.9 \mathrm{a}$ & $6.8 a b$ & $14.1 \mathrm{~b}$ & $9.2 \mathrm{a}$ \\
\hline Mean & 237.1 & 423.7 & 660.8 & 35.8 & 25.0 & 6.8 & 12.8 & 10.0 \\
\hline GL_large & 323.7 & $489.9 \mathrm{~b}$ & $813.6 \mathrm{~b}$ & 39.7 & $36.2 \mathrm{~b}$ & 6.8 & 16.4 & $11.5 \mathrm{~b}$ \\
\hline GL_small & 302.2 & $444.1 \mathrm{a}$ & 746.3 a & 40.5 & $24.3 \mathrm{a}$ & 6.8 & 16.8 & $8.9 \mathrm{a}$ \\
\hline GL_0 & 324.2 & $468.7 \mathrm{ab}$ & $793.0 \mathrm{ab}$ & 40.9 & $35.4 \mathrm{~b}$ & 6.6 & 17.0 & $11.3 \mathrm{~b}$ \\
\hline GL_R_10 & 321.7 & $476.9 \mathrm{~b}$ & $798.6 a b$ & 40.3 & $35.6 \mathrm{~b}$ & 6.8 & 16.2 & $11.1 \mathrm{~b}$ \\
\hline Mean & 318.0 & 469.9 & 787.9 & 40.3 & 32.9 & 6.7 & 16.6 & 10.7 \\
\hline Mean & 255.5 & 444.3 & 699.8 & 36.1 & 37.4 & 6.7 & 13.4 & 11.5 \\
\hline
\end{tabular}

a) Mean values followed by the same letter column-wise are not significantly different in Tukey's-HSD test at P=0.05.

TABLE 4.4 Mean values at Schönhagen for seed yield (KY), straw yield (SY), total yield (TY), harvest index $(\mathrm{HI})$, seed weight (SW), ripening scores (RP), and flowering scores sum (FTsum) across years for selections for large and small seeds, the initial population (0), and the population under natural selection in the $10^{\text {th }}$ generation from Schönhagen for each cultivar (PP, SL, GL).

\begin{tabular}{lccccccc}
\hline Selection & $\mathbf{K Y}\left[\mathrm{gm}^{-2}\right]$ & $\mathbf{S Y}\left[\mathrm{gm}^{-2}\right]$ & $\mathbf{T Y}\left[\mathrm{gm}^{-2}\right]$ & $\mathbf{H I}$ & $\mathbf{S W}[\mathrm{mg}]$ & $\mathbf{R P}$ & FTsum \\
\hline PP_large & 101.1 & $196.3 \mathrm{~b}^{\mathrm{a}}$ & 297.4 & 35.9 & $65.4 \mathrm{c}$ & 4.3 & $12.9 \mathrm{bc}$ \\
PP_Small & 104.1 & $170.1 \mathrm{ab}$ & 274.1 & 38.9 & $44.2 \mathrm{a}$ & 5.1 & $10.9 \mathrm{a}$ \\
PP_0 & 94.8 & $162.3 \mathrm{a}$ & 257.0 & 37.9 & $60.8 \mathrm{~b}$ & 4.4 & $13.1 \mathrm{c}$ \\
PP_S_10 & 106.7 & $183.6 \mathrm{ab}$ & 290.3 & 37.1 & $60.7 \mathrm{~b}$ & 4.4 & $11.4 \mathrm{ab}$ \\
\hline \multicolumn{1}{c}{ Mean } & 101.7 & 178.0 & 279.7 & 37.4 & 57.8 & 4.5 & 12.1 \\
\hline SL_large & $150.1 \mathrm{~b}$ & $196.3 \mathrm{~b}$ & $346.5 \mathrm{~b}$ & $43.5 \mathrm{~b}$ & $32.9 \mathrm{~b}$ & 4.7 & $12.7 \mathrm{ab}$ \\
SL_Small & $90.6 \mathrm{a}$ & $135.9 \mathrm{a}$ & $226.5 \mathrm{a}$ & $39.3 \mathrm{a}$ & $23.1 \mathrm{a}$ & 5.0 & $12.8 \mathrm{ab}$ \\
SL_0 & $93.4 \mathrm{a}$ & $140.0 \mathrm{a}$ & $233.5 \mathrm{a}$ & $39.3 \mathrm{a}$ & $23.5 \mathrm{a}$ & 4.6 & $11.4 \mathrm{a}$ \\
SL_S_10 & $101.7 \mathrm{a}$ & $145.4 \mathrm{a}$ & $247.0 \mathrm{a}$ & $40.6 \mathrm{ab}$ & $23.5 \mathrm{a}$ & 5.0 & $13.7 \mathrm{~b}$ \\
\hline \multicolumn{1}{c}{ Mean } & 108.9 & 154.4 & 263.3 & 40.7 & 25.7 & 4.8 & 12.7 \\
\hline GL_large & 183.2 & 205.4 & 388.6 & 52.0 & $36.2 \mathrm{~b}$ & 4.9 & $18.0 \mathrm{ab}$ \\
GL_Small & 152.5 & 192.8 & 345.3 & 45.2 & $24.7 \mathrm{a}$ & 5.3 & $19.9 \mathrm{c}$ \\
GL_0 & 156.1 & 307.8 & 463.9 & 40.2 & $35.3 \mathrm{~b}$ & 5.3 & $17.9 \mathrm{a}$ \\
GL_S_10 & 185.2 & 213.5 & 398.6 & 47.5 & $35.0 \mathrm{~b}$ & 5.2 & $18.9 \mathrm{abc}$ \\
\hline \multicolumn{1}{c}{ Mean } & 169.2 & 229.9 & 399.1 & 46.2 & 32.8 & 5.1 & 18.7 \\
$\quad$ Mean & 126.6 & 187.4 & 314.1 & 41.4 & 38.8 & 4.8 & 14.5 \\
\hline
\end{tabular}

a) Mean values followed by the same letter column-wise are not significantly different in Tukey's-HSD test at P=0.05. 
TABLE 4.5 Mean values at Tangsehl for seed yield (KY), straw yield (SY), total yield (TY), harvest index (HI), seed weight (SW), ripening scores (RP), and flowering scores sum (FTsum) across years for selections for large and small seeds, the initial population (0), and the population under natural selection in the $10^{\text {th }}$ generation from Tangsehl for each cultivar (PP, SL, GL).

\begin{tabular}{lccccccc} 
Selection & $\mathbf{K Y}\left[\mathrm{gm}^{-2}\right]$ & $\mathbf{S Y}\left[\mathrm{gm}^{-2}\right]$ & $\mathbf{T Y}\left[\mathrm{gm}^{-2}\right]$ & $\mathbf{H I}$ & $\mathbf{S W}[\mathrm{mg}]$ & $\mathbf{R P}$ & FTsum \\
\hline PP_large & 122.4 & 105.8 & 228.2 & 41.8 & $65.5 \mathrm{~d}^{\mathrm{a})}$ & $6.0 \mathrm{a}$ & $15.7 \mathrm{ab}$ \\
PP_small & 90.1 & 89.2 & 179.3 & 47.0 & $46.6 \mathrm{a}$ & $6.3 \mathrm{ab}$ & $15.3 \mathrm{a}$ \\
PP_0 & 60.7 & 95.0 & 155.7 & 40.8 & $59.3 \mathrm{c}$ & $6.4 \mathrm{ab}$ & $16.2 \mathrm{ab}$ \\
PP_T_10 & 66.8 & 90.8 & 157.6 & 42.8 & $51.3 \mathrm{~b}$ & $6.7 \mathrm{~b}$ & $16.6 \mathrm{~b}$ \\
\hline \multicolumn{1}{c}{ Mean } & 85.0 & 95.2 & 180.2 & 43.1 & 55.7 & 6.4 & 15.9 \\
\hline SL_large & $74.1 \mathrm{~b}$ & 96.1 & 170.2 & $44.3 \mathrm{~b}$ & $33.8 \mathrm{~b}$ & 7.1 & $15.5 \mathrm{a}$ \\
SL_Small & $56.5 \mathrm{a}$ & 85.4 & 141.9 & $40.1 \mathrm{a}$ & $23.9 \mathrm{a}$ & 7.3 & $17.7 \mathrm{~b}$ \\
SL_0 & $59.7 \mathrm{ab}$ & 90.4 & 150.0 & $39.8 \mathrm{a}$ & $24.5 \mathrm{a}$ & 7.5 & $17.5 \mathrm{~b}$ \\
SL_T_10 & $59.2 \mathrm{ab}$ & 91.3 & 150.6 & $39.8 \mathrm{a}$ & $24.4 \mathrm{a}$ & 7.3 & $17.7 \mathrm{~b}$ \\
\hline \multicolumn{1}{c}{ Mean } & 62.4 & 90.8 & 153.2 & 41.0 & 26.6 & 7.3 & 17.1 \\
\hline GL_large & $89.8 \mathrm{~b}$ & 93.0 & 182.9 & 50.4 & $37.5 \mathrm{~b}$ & 7.3 & 21.3 \\
GL_Small & $65.1 \mathrm{a}$ & 121.0 & 186.1 & 44.1 & $26.4 \mathrm{a}$ & 7.3 & 22.0 \\
GL_0 & $87.2 \mathrm{~b}$ & 86.1 & 173.3 & 50.8 & $37.4 \mathrm{~b}$ & 7.3 & 21.8 \\
GL_T_10 & $85.0 \mathrm{~b}$ & 89.2 & 174.2 & 49.9 & $37.5 \mathrm{~b}$ & 7.3 & 21.6 \\
\hline \multicolumn{1}{c}{ Mean } & 81.8 & 97.3 & 179.1 & 48.8 & 34.7 & 7.3 & 21.6 \\
$\quad$ Mean & 76.4 & 94.4 & 170.8 & 44.3 & 39.0 & 7.0 & 18.2 \\
\hline
\end{tabular}

a) Mean values followed by the same letter column-wise are not significantly different in Tukey's-HSD test at P=0.05.

Different proportions of seedlings with red pigmentation on the hypocotyl were found between selections and populations of Pisarecka Perla, as shown in TABLE 4.6. Selection for small seeds significantly increased the proportion of red seedling. Natural selection at Tangsehl reducing seed weight also increase the proportion of red seedlings, whereas populations form Reinshof and Schönhagen exhibit a rather low proportion with $<5 \%$ and within the selection for large seeds $10-15 \%$ of red seedlings were found.

TABLE 4.6 Proportion [\%] of seedlings with red pigmentation on the hypocotyl in selections for large and small seeds of Pisarecka Perla, the initial population (0), and the populations in $10^{\text {th }}$ generation under natural selection at the three farms $(R, S, T)$ observed and counted during field testing at the same three locations.

\begin{tabular}{lcccr}
\hline Selection & Reinshof & Schönhagen & Tangsehl & Mean \\
\hline PP_large & 15.3 & 10.9 & 12.8 & 13.0 \\
PP_small & 74.0 & 70.7 & 66.6 & 70.5 \\
PP_0 & 10.4 & 3.4 & 6.6 & 6.8 \\
PP_R_10 & 0.6 & 0.3 & 3.5 & 1.5 \\
PP_S_10 & 3.3 & 2.6 & 4.8 & 3.6 \\
PP_T_10 & 45.8 & 34.2 & 38.1 & 39.4 \\
\hline
\end{tabular}


PROGENY TESTING TRIALS

Variance components of selections per cultivar were calculated and are summarized for 50 single plant progenies tested during two years at Reinshof in TABLE 4.7. Significant variation was observed for most of the traits within between progenies of selections within Pisarecka Perla. Seed weight and flowering score sums show the highest heritability and significant variation for progenies within all cultivars.

TABLE 4.7 Variance components with their significance levels ${ }^{a)}$ and heritability values of phenotypic traits assessed on 50 single plant progenies per selection during 2015 and 2016.

\begin{tabular}{|c|c|c|c|c|c|c|}
\hline \multicolumn{7}{|c|}{ Pisarecka Perla } \\
\hline Trait & $\begin{array}{l}\text { Year } \\
(\mathrm{DF}=1)\end{array}$ & $\begin{array}{l}\text { Selection } \\
\quad(D F=1)\end{array}$ & $\begin{array}{c}\mathbf{Y x S} \\
(\mathrm{DF}=1)\end{array}$ & $\begin{array}{c}\text { Progeny } \\
(D F=98)\end{array}$ & $\begin{array}{c}\text { Residual } \\
(\mathrm{DF}=95)\end{array}$ & $h^{2}$ \\
\hline Seed yield & $1219 * *$ & $0^{b)}$ & $537.5^{* *}$ & $605.6 * *$ & 621.9 & 66.07 \\
\hline Straw yield & $252.5^{* *}$ & 10.05 & $581.9 * *$ & $720.4^{* *}$ & 2098 & 40.72 \\
\hline Total yield & $2495^{* *}$ & 0 & $2447^{* *}$ & $2515^{* *}$ & 3564 & 58.53 \\
\hline Harvest index & $0.009 * *$ & $0.0001^{*}$ & $0.002 * *$ & $0.002 * *$ & 0.003 & 62.45 \\
\hline Seed weight & $32.99 * *$ & $173.1^{* *}$ & $19.35 * *$ & $15.61 * *$ & 11.85 & 72.49 \\
\hline Leaf size score & $0.556^{* *}$ & $0.556 * *$ & $0.280 * *$ & 0 & 0.564 & 0 \\
\hline Leaf size scan & 0 & $6.483 * *$ & $1.384 * *$ & $1.303^{*}$ & 4.569 & 36.32 \\
\hline Flowering score sum & $0.416 * *$ & 0 & $0.180^{+}$ & $9.471 * *$ & 3.514 & 84.35 \\
\hline Ripening & $0.328 * *$ & 0 & $0.656^{* *}$ & 0.016 & 0.814 & 3.72 \\
\hline \multicolumn{7}{|c|}{ Schwarze Linse } \\
\hline Seed yield & 0 & $601.9 * *$ & $350.5^{* *}$ & 0 & 670.7 & 0 \\
\hline Straw yield & $99.51 * *$ & $3336 * *$ & $1835^{* *}$ & 32.88 & 1651 & 3.83 \\
\hline Total yield & $79.23^{+}$ & $6784 * *$ & $3813^{* *}$ & 0 & 3362 & 0 \\
\hline Harvest index & $0.0003^{* *}$ & $0.0009 * *$ & $0.0007^{* *}$ & 0.0003 & 0.004 & 12.84 \\
\hline Seed weight & $4.063 * *$ & $36.61 * *$ & $0.92 * *$ & $1.415^{* *}$ & 2.749 & 50.74 \\
\hline Leaf size score & $0.475^{* *}$ & $2.415^{* *}$ & $0.837 * *$ & 0 & 0.497 & 0 \\
\hline Leaf size scan & 0 & $4.033 * *$ & $0.357 * *$ & 0 & 2.773 & 0 \\
\hline Flowering score sum & $14.59 * *$ & $6.371 * *$ & 0 & $3.569 * *$ & 1.914 & 78.86 \\
\hline Ripening & $0.255^{* *}$ & $0.542 * *$ & $0.09 * *$ & 0.061 & 0.39 & 23.71 \\
\hline \multicolumn{7}{|c|}{ Gestreifte Linse } \\
\hline Seed yield & 0 & 1085 & $14.93^{* *}$ & 92.00 & 1363 & 11.90 \\
\hline Straw yield & 3.483 & $557.0 * *$ & $1509 * *$ & $602.9 *$ & 2476 & 32.75 \\
\hline Total yield & 0 & $3221 * *$ & $971.9 * *$ & $1175^{*}$ & 5796 & 28.85 \\
\hline Harvest index & 0 & $0.002 * *$ & $0.002 * *$ & 0 & 0.004 & 0 \\
\hline Seed weight & $1.823 * *$ & $58.59 * *$ & 0 & $2.549 * *$ & 3.766 & 57.52 \\
\hline Leaf size score & 0.001 & $1.580 * *$ & $0.284 * *$ & $0.066^{+}$ & 0.377 & 25.86 \\
\hline Leaf size scan & $0.305 * *$ & $3.389 * *$ & 0.009 & 0 & 2.733 & 0 \\
\hline Flowering score sum & $7.773 * *$ & $0.019^{+}$ & $2.688 * *$ & $1.448 * *$ & 0.897 & 76.35 \\
\hline Ripening & $0.106 * *$ & $0.018 *$ & 0 & 0 & 0.412 & 0 \\
\hline
\end{tabular}


TABLE 4.8 Means, standard error of means (SE), minimum, maximum and range, variance and the coefficient of variation (CV) of all traits for selections on small and large seeds from three cultivars (PP, $\mathrm{SL}, \mathrm{GL})$.

\begin{tabular}{|c|c|c|c|c|c|c|c|c|}
\hline Trait & Population & Mean $^{\text {a) }}$ & SE & Min. & Max. & Range & Variance $^{\text {b) }}$ & CV \\
\hline \multicolumn{9}{|c|}{ Pisarecka Perla (PP) } \\
\hline \multirow{2}{*}{$\begin{array}{l}\text { Seed } \\
\text { yield }[\mathrm{g}]\end{array}$} & PP_large & 59.26 & 2.53 & 17.33 & 118.23 & 100.9 & 319ns & 30.14 \\
\hline & PP_small & 62.63 & 5.50 & 17.73 & 180.43 & 162.7 & $1514^{* *}$ & 62.14 \\
\hline \multirow{2}{*}{$\begin{array}{l}\text { Straw } \\
\text { yield }[g]\end{array}$} & PP_large & 221.9 & 5.94 & 133.2 & 317.7 & 184.5 & $1763^{+}$ & 18.92 \\
\hline & PP_small & 214.0 & 5.96 & 149.9 & 312.6 & 162.7 & $1775^{*}$ & 19.69 \\
\hline \multirow{2}{*}{$\begin{array}{l}\text { Total } \\
\text { yield [g] }\end{array}$} & PP_large & 281.2 & 7.18 & 178.9 & 359.1 & 180.2 & $2578 n s$ & 18.06 \\
\hline & PP_small & 278.4 & 10.97 & 170.5 & 476.1 & 305.7 & $6016^{* *}$ & 27.86 \\
\hline \multirow{2}{*}{$\begin{array}{l}\text { Harvest } \\
\text { index }\end{array}$} & PP_large & $0.187 \mathrm{a}$ & 0.006 & 0.080 & 0.330 & 0.250 & $0.002^{*}$ & 24.51 \\
\hline & PP_small & $0.203 \mathrm{~b}$ & 0.010 & 0.090 & 0.380 & 0.290 & $0.005^{* *}$ & 35.74 \\
\hline \multirow{2}{*}{$\begin{array}{l}\text { Seed } \\
\text { weight }[\mathrm{mg}]\end{array}$} & PP_large & $56.20 \mathrm{~b}$ & 0.51 & 47.95 & 67.19 & 19.24 & $12.81^{*}$ & 6.37 \\
\hline & PP_small & $37.58 \mathrm{a}$ & 0.78 & 21.19 & 51.70 & 30.51 & $30.28 * *$ & 14.64 \\
\hline \multirow{2}{*}{$\begin{array}{l}\text { Leaf size } \\
\text { score }\end{array}$} & PP_large & $6.70 \mathrm{~b}$ & 0.06 & 5.00 & 7.00 & 2.00 & $0.16^{+}$ & 6.03 \\
\hline & PP_small & $5.64 \mathrm{a}$ & 0.09 & 4.00 & 6.50 & 2.50 & $0.37 \mathrm{~ns}$ & 10.75 \\
\hline \multirow{2}{*}{$\begin{array}{l}\text { Leaf size } \\
\text { scan }\left[\mathrm{cm}^{2}\right]\end{array}$} & PP_large & $14.85 \mathrm{~b}$ & 0.28 & 10.80 & 19.12 & 8.32 & $3.92 \mathrm{~ns}$ & 13.33 \\
\hline & PP_small & $11.24 \mathrm{a}$ & 0.26 & 7.23 & 16.24 & 9.01 & $3.25 *$ & 16.05 \\
\hline \multirow{2}{*}{$\begin{array}{l}\text { Flowering } \\
\text { score sum }\end{array}$} & PP_large & 9.15 & 0.52 & 3.50 & 19.50 & 16.00 & $13.43 * *$ & 40.08 \\
\hline & PP_small & 9.06 & 0.42 & 2.00 & 15.00 & 13.00 & $9.02 * *$ & 33.17 \\
\hline \multirow{2}{*}{$\begin{array}{l}\text { Ripening } \\
\text { score }\end{array}$} & PP_large & 6.46 & 0.08 & 5.00 & 8.00 & 3.00 & $0.36 \mathrm{~ns}$ & 9.23 \\
\hline & PP_small & 6.50 & 0.10 & 5.00 & 8.00 & 3.00 & $0.49 \mathrm{~ns}$ & 10.77 \\
\hline \multicolumn{9}{|c|}{ Schwarze Linse (SL) } \\
\hline \multirow{2}{*}{$\begin{array}{l}\text { Seed } \\
\text { yield }[\mathrm{g}]\end{array}$} & SL_large & $73.46 b$ & 3.24 & 18.73 & 112.41 & 93.68 & $526 n s$ & 31.23 \\
\hline & SL_small & $38.56 \mathrm{a}$ & 1.54 & 14.18 & 61.57 & 47.39 & $118 \mathrm{~ns}$ & 28.16 \\
\hline \multirow{2}{*}{$\begin{array}{l}\text { Straw } \\
\text { yield }[\mathrm{g}]\end{array}$} & SL_large & $255.9 \mathrm{~b}$ & 4.55 & 162.9 & 336.4 & 173.5 & $1034 n s$ & 12.57 \\
\hline & SL_small & $174.0 \mathrm{a}$ & 3.70 & 113.0 & 255.4 & 142.4 & 683 ns & 15.02 \\
\hline \multirow{2}{*}{$\begin{array}{l}\text { Total } \\
\text { yield [g] }\end{array}$} & SL_large & $329.3 \mathrm{~b}$ & 6.21 & 181.7 & 408.2 & 226.5 & 1929ns & 13.34 \\
\hline & SL_small & $212.6 \mathrm{a}$ & 4.85 & 127.2 & 313.7 & 186.5 & $1175 n s$ & 16.13 \\
\hline \multirow{2}{*}{$\begin{array}{l}\text { Harvest } \\
\text { index }\end{array}$} & SL_large & $0.216 \mathrm{~b}$ & 0.008 & 0.070 & 0.350 & 0.280 & $0.003 \mathrm{~ns}$ & 25.46 \\
\hline & SL_small & $0.175 a$ & 0.005 & 0.110 & 0.240 & 0.130 & $0.001 \mathrm{~ns}$ & 18.63 \\
\hline \multirow{2}{*}{$\begin{array}{l}\text { Seed } \\
\text { weight [mg] }\end{array}$} & SL_large & $29.47 b$ & 0.29 & 23.07 & 34.64 & 11.57 & $4.16^{* *}$ & 6.92 \\
\hline & SL_small & $20.91 \mathrm{a}$ & 0.17 & 18.15 & 24.72 & 6.57 & $1.42 \mathrm{~ns}$ & 5.70 \\
\hline \multirow{2}{*}{$\begin{array}{l}\text { Leaf size } \\
\text { score }\end{array}$} & SL_large & $5.17 \mathrm{~b}$ & 0.09 & 3.50 & 6.00 & 2.50 & $0.42 n s$ & 12.60 \\
\hline & SL_small & $2.97 \mathrm{a}$ & 0.02 & 2.50 & 3.50 & 1.00 & $0.02 \mathrm{~ns}$ & 5.28 \\
\hline \multirow{2}{*}{$\begin{array}{l}\text { Leaf size } \\
\text { scan }\left[\mathrm{cm}^{2}\right]\end{array}$} & SL_large & $10.39 \mathrm{~b}$ & 0.17 & 7.99 & 13.11 & 5.12 & $1.51 \mathrm{~ns}$ & 11.81 \\
\hline & SL_small & $7.54 \mathrm{a}$ & 0.13 & 5.79 & 10.14 & 4.35 & $0.86 n s$ & 12.33 \\
\hline \multirow{2}{*}{$\begin{array}{l}\text { Flowering } \\
\text { score sum }\end{array}$} & SL_large & $7.90 \mathrm{a}$ & 0.41 & 4.00 & 17.75 & 13.75 & $8.43^{* *}$ & 36.74 \\
\hline & SL_small & $11.48 \mathrm{~b}$ & 0.11 & 9.25 & 13.50 & 4.25 & $0.63 \mathrm{~ns}$ & 6.89 \\
\hline \multirow{2}{*}{$\begin{array}{l}\text { Ripening } \\
\text { score }\end{array}$} & SL_large & $6.68 \mathrm{a}$ & 0.07 & 5.20 & 7.50 & 2.30 & $0.27 n s$ & 7.78 \\
\hline & SL_small & $7.84 \mathrm{~b}$ & 0.07 & 6.52 & 9.00 & 2.48 & $0.24 \mathrm{~ns}$ & 6.26 \\
\hline
\end{tabular}

a) Mean values followed by the same letter within the same cultivar are not significantly different after Tukey'sHSD test with $\mathrm{P}=0.05$.

b) Significance levels of the effect of progenies within population from the F-test in ANOVA is given with: $* *, *,+$, ns for P-values $=0.01,0.05,0.1$, non-significant, respectively.

Table continues on the next page. 
Table 4.8 continued.

\begin{tabular}{|c|c|c|c|c|c|c|c|c|}
\hline \multicolumn{9}{|c|}{ Gestreifte Linse (GL) } \\
\hline Trait & Population & Mean $^{a)}$ & SE & Min. & Max. & Range & Variance $^{\text {b) }}$ & CV \\
\hline \multirow{2}{*}{$\begin{array}{l}\text { Seed } \\
\text { yield }[g]\end{array}$} & GL_large & $130.70 \mathrm{~b}$ & 4.12 & 61.04 & 189.11 & 128.07 & $848^{*}$ & 22.28 \\
\hline & GL_small & $83.83 \mathrm{a}$ & 3.74 & 32.23 & 149.75 & 117.52 & 699ns & 31.53 \\
\hline \multirow{2}{*}{$\begin{array}{l}\text { Straw } \\
\text { yield }[\mathrm{g}]\end{array}$} & GL large & $267.1 b$ & 5.64 & 165.0 & 342.0 & 177.1 & $1591^{+}$ & 14.93 \\
\hline & GL_small & $233.0 \mathrm{a}$ & 6.47 & 154.9 & 341.9 & 187.0 & $2091^{+}$ & 19.62 \\
\hline \multirow{2}{*}{$\begin{array}{l}\text { Total } \\
\text { yield }[\mathrm{g}]\end{array}$} & GL_large & $397.9 \mathrm{~b}$ & 8.89 & 226.0 & 506.0 & 280.0 & $3948^{*}$ & 15.79 \\
\hline & GL_small & 316.9 a & 9.16 & 193.5 & 482.2 & 288.7 & 4198ns & 20.45 \\
\hline \multirow{2}{*}{$\begin{array}{l}\text { Harvest } \\
\text { index }\end{array}$} & GL_large & $0.325 \mathrm{~b}$ & 0.005 & 0.230 & 0.390 & 0.160 & $0.001 \mathrm{~ns}$ & 11.69 \\
\hline & GL_small & $0.256 \mathrm{a}$ & 0.007 & 0.140 & 0.360 & 0.220 & $0.003 n s$ & 19.91 \\
\hline \multirow{2}{*}{$\begin{array}{l}\text { Seed } \\
\text { weight }[\mathrm{mg}]\end{array}$} & GL_large & $34.54 \mathrm{~b}$ & 0.28 & 26.43 & 39.97 & 13.54 & $3.90 * *$ & 5.72 \\
\hline & GL_small & $23.71 \mathrm{a}$ & 0.31 & 20.35 & 33.60 & 13.25 & $4.96 * *$ & 9.39 \\
\hline \multirow{2}{*}{$\begin{array}{l}\text { Leaf size } \\
\text { score }\end{array}$} & GL_large & $5.22 b$ & 0.07 & 4.50 & 6.00 & 1.50 & $0.23 \mathrm{~ns}$ & 9.11 \\
\hline & GL_small & $3.44 \mathrm{a}$ & 0.08 & 3.00 & 6.00 & 3.00 & $0.28 * *$ & 15.44 \\
\hline \multirow{2}{*}{$\begin{array}{l}\text { Leaf size } \\
\text { scan }\left[\mathrm{cm}^{2}\right]\end{array}$} & GL_large & $9.72 \mathrm{~b}$ & 0.15 & 6.93 & 12.67 & 5.74 & $1.18 \mathrm{~ns}$ & 11.19 \\
\hline & GL_small & $7.10 \mathrm{a}$ & 0.11 & 5.75 & 9.55 & 3.80 & $0.65^{+}$ & 11.33 \\
\hline \multirow{2}{*}{$\begin{array}{l}\text { Flowering } \\
\text { score sum }\end{array}$} & GL_large & 6.58 & 0.18 & 4.50 & 11.50 & 7.00 & $1.62 * *$ & 19.33 \\
\hline & GL_small & 6.34 & 0.21 & 3.00 & 9.00 & 6.00 & $2.18^{* *}$ & 23.28 \\
\hline \multirow{2}{*}{$\begin{array}{l}\text { Ripening } \\
\text { score }\end{array}$} & GL_large & $7.56 \mathrm{~b}$ & 0.05 & 7.00 & 8.50 & 1.50 & $0.12 n s$ & 4.56 \\
\hline & GL_small & $7.35 \mathrm{a}$ & 0.06 & 6.50 & 8.00 & 1.50 & $0.21 \mathrm{~ns}$ & 6.18 \\
\hline \multicolumn{9}{|c|}{$\begin{array}{l}\text { a) Mean values followed by the same letter within the same cultivar are not significantly different after Tukey's- } \\
\text { HSD test with } P=0.05 \text {. }\end{array}$} \\
\hline \multicolumn{9}{|c|}{$\begin{array}{l}\text { b) Significance levels of the effect of progenies within population from the F-test in ANOVA is given with: } \\
\qquad * *, *,+ \text { ns for P-values }=0.01,0.05,0.1 \text {, non-significant, respectively. }\end{array}$} \\
\hline
\end{tabular}

Statistically highly significant variation within selections was observed in PP_small for seed yield, harvest index, seed weight, and flowering (TABLE 4.8). The on average significantly earlier flowering PP_large also holds a highly significant within-population variance and a larger coefficient of variation for the same trait, while for all other traits, PP_small holds the higher CV compared to PP_large.

Mean comparisons between SL_large and SL_small are significant for all traits (TABLE 4.8). Significant variation was observed within SL_large for seed weight and flowering. Additionally, a higher coefficient of variation was found for seed yield, harvest index, leaf size score, and ripening score in SL_large compared to SL_small.

The comparison of means between the two selections of GL are significant in all cases, except for flowering (TABLE 4.8). Highly significant within-population variation was identified for seed yield and flowering in both selections. Additionally, GL_large holds a significant variance for seed yield and total yield, but coefficients of variation are smaller compared to GL_small in these traits as well as for all other traits. 


\section{GENOTYPIC RESULTS}

In total 40-41 individuals per selection were genotyped successfully with 145 SNP marker (TABLE 4.9). Ten additional individuals differing in seed color from Schwarze Linse observed in the large selection (SL_largeX) were genotyped to check their genetic origin.

TABLE 4.9 Results from genotyping with 145 SNP marker.

\begin{tabular}{lcccc}
\hline Population & $\begin{array}{c}\text { Number of } \\
\text { polymorphic } \\
\text { homozygous loci } \\
\text { (number of samples) }\end{array}$ & $\begin{array}{c}\text { Number of } \\
\text { heterozygous } \\
\text { loci }\end{array}$ & $\begin{array}{c}\text { Number of heterozygous } \\
\text { samples with H>5\% } \\
\text { (Number or range of } \\
\text { heterozygous loci) }\end{array}$ & $\begin{array}{c}\text { Number of } \\
\text { samples }\end{array}$ \\
\hline PP_large & 53 & 31 & $1(31)$ & 40 \\
PP_small & 139 & 62 & $4(8-28)$ & 40 \\
\hline SL_large & 82 & 30 & $1(14)$ & 40 \\
SL_Small & $4(1)$ & 2 & 0 & 40 \\
\hline GL_large & 84 & 7 & 0 & 41 \\
GL_Small & 80 & 29 & $1(18)$ & 40 \\
\hline SL_largeX & 107 & 25 & $1(18)$ & 10 \\
\hline a) If only few individuals are contributing to polymorphisms, the number of individuals is given in brackets.
\end{tabular}

Within selection PP_large, 30 individuals were identified to be completely homogeneous for all markers applied (FIGURE 4.1-4.2). The other ten individuals differ in sum for 53 loci in homozygous status from the homogeneous majority of individuals and include one heterozygous individual in 31 loci; 12 of these heterozygous loci were not polymorphic within PP_large, but in PP_small.

The small seeded selection PP_small consists of a major and more or less homogeneous group of 25 individuals. The 15 other individuals are highly heterogeneous and partly heterozygous and cluster with other heterogeneous and partly heterozygous individuals of SL_large, SL_largeX, GL_large and PP_large.

Individuals of the large seeded selection of SL are clustered in one main cluster with a certain variability within the cluster with in total 39 samples, one sample (SL_large_96) in larger distance from the others close to the SL_small genotype. The individuals of SL_largeX are clustering relatively closely to either SL_large or SL_small with eight and two individuals, respectively, together with other heterogeneous and partly heterozygous individuals of PP_small.

SL_small consists of 40 highly homogeneous genotypes, with one individual (SL_small_10) differing in four loci from the other samples and one sample having one additional loci in heterozygous status. Loci Contig14652 is heterozygous throughout all samples of SL_small, whereas the same loci is either homozygous $\mathrm{TT}$ (24 samples) or heterozygous TG (14 samples) in SL_large, except for SL_large_96 which is homozygous GG. 
In population GL_large, 39 individuals are completely identical and homozygous except for sample GL_large_09 with one loci in heterozygous status. Two samples GL_large_84 and 96 differing in 33 and 27 loci from the other 39 samples, respectively, plus seven additional heterozygous loci for the latter, are clustering together with the heterogeneous and partly heterozygous individuals of PP_small and SL_largeX.All 40 individuals of GL_small are clustering together, however they are divided into two main clusters consisting of 17 and 23 samples each. The larger group of samples is more heterogeneous and includes one sample in heterozygous status at 18 loci.

FIGURE 4.1 Minimum-variance-dendrogram of all genotyped individuals from selections of three cultivars (PP, SL, GL) for

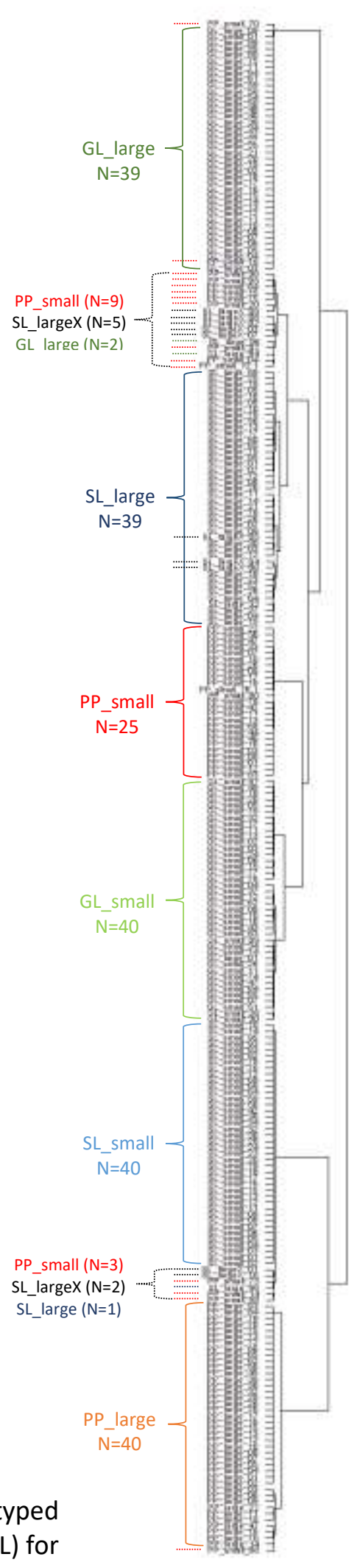
small and large seed size. 

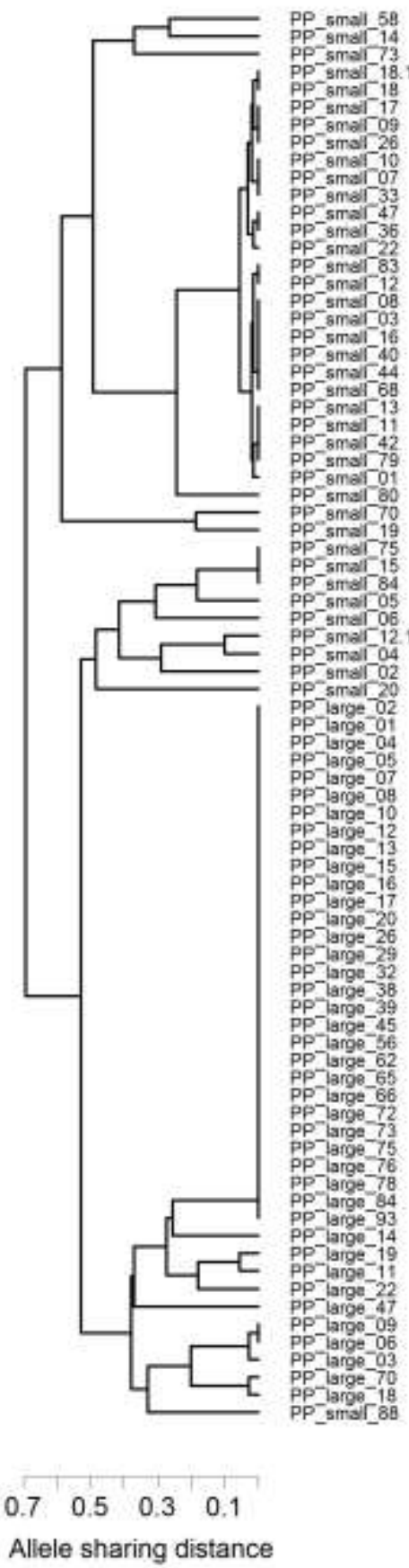

PP_smar_88

$\begin{array}{llll}0.7 & 0.5 & 0.3 & 0.1\end{array}$

Allele sharing distance
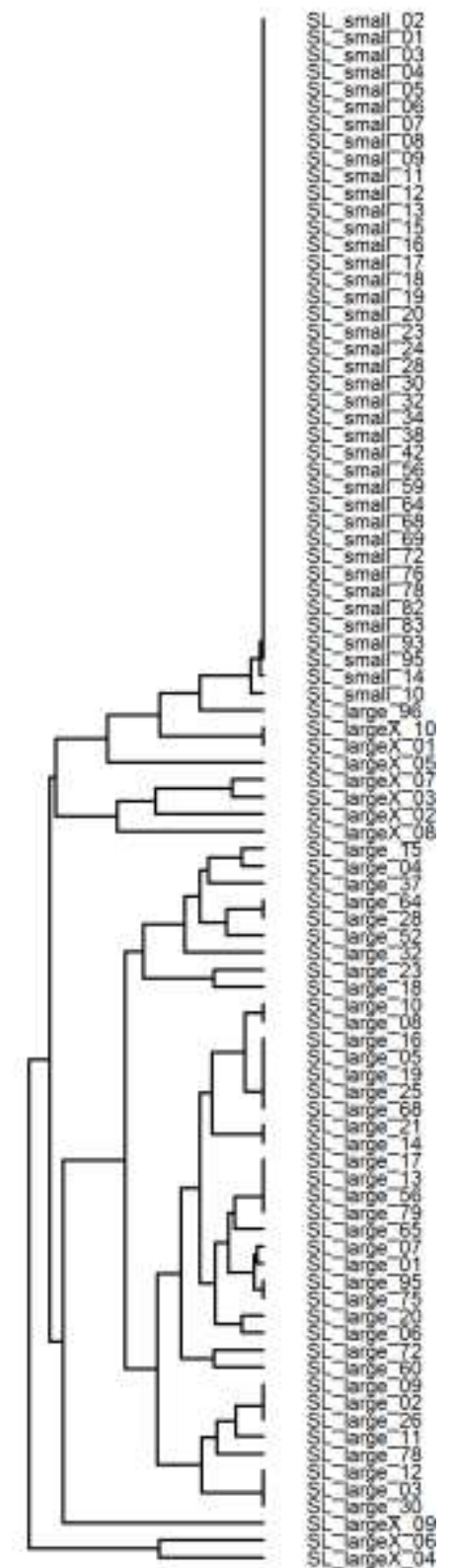

$\begin{array}{lll}0.5 & 0.3 & 0.1\end{array}$

Allele sharing distance

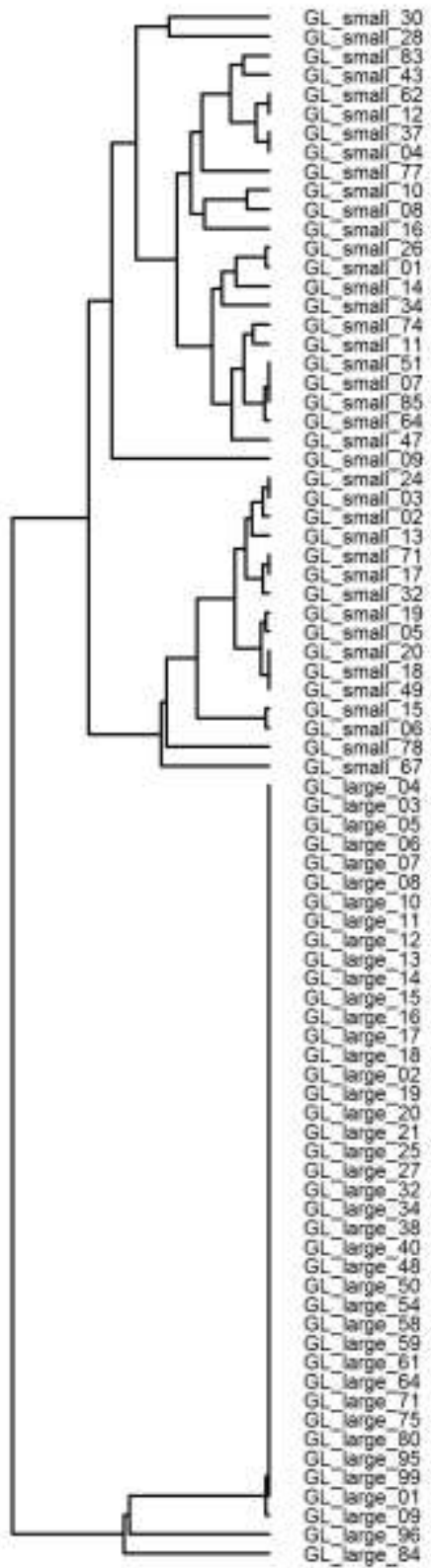

$\begin{array}{lll}0.5 & 0.3 & 0.1\end{array}$

Allele sharing distance

FIGURE 4.2 UPGMA dendrograms for individuals from cultivar Pisarecka Perla (PP), Schwarze Linse (SL), and Gestreifte Linse (GL), from left to right, resulting from selection on seed size (large, small). Ten extra samples (SL_largeX) are phenotypically deviating for seed color from the original cultivar. 


\subsection{Discussion}

Across year and location, the selection for extreme seed size had a significant effect on seed yield in Schwarze Linse and Gestreifte Linse, on straw yield in Schwarze Linse and Pisarecka Perla, and on total yield and harvest index in Schwarze Linse. Seed weight and flowering time was altered significantly by the selection in all three cultivars. In Pisarecka Perla, seed, straw, and total yield seem to be improved with the selection on seed size, regardless of the direction for small or large seeds. However, the large seeded selection seems to have a minor advantage over the small seeded. On the other hand, the harvest index decreased by the selection on large seeds to 36.1 from 38.0 in the initial population, compared to 39.3 in the small seeded selection, and ripening slightly delayed. Selection for large seed size in Schwarze Linse and Gestreifte Linse improved seed yield significantly and led to an increased harvest index, whereas the small seeded selections do not differ significantly from the initial populations, except for Gestreifte Linse in seed weight, and yield was slightly lower compared to the initial populations.

For the site-specific comparisons, the large seeded selection in Pisarecka Perla revealed the highest straw yield in all locations and the highest seed yield in Tangsehl. At Reinshof, the initial population gave the highest seed yield and in Schönhagen it was the 'Schönhagen population' under natural selection with the best yield. However, all mean comparisons for seed yield are statistically not significant. For Reinshof, across the two years, which differed strongly in the precipitation distribution and disease pressure, both selection methods (sieving and natural selection) for larger seeds increased the straw yield potential, but not the seed yield, thus the harvest index decreased. Furthermore ripening is slightly delayed. Flowering was observed significantly later in the 'Reinshof selection', compared to the small and large seeded selections. The initial population and the large seeded selection were flowering earliest. Thus, seed weight and flowering are not correlated here and the season length from flowering until ripening is shorter in the 'Reinshof selection', which might explain the lower straw yield compared to the large seeded selection. At Schönhagen, the 'Schönhagen population' yields highest in seed and second highest in straw yield. Seed weight is similar compared to the initial population as well as ripening, but the harvest index is slightly reduced and flowering time significantly delayed. The large seeded selection performs relatively well and might have a small advantage over the small seeded selection from earlier flowering and later ripening at this location. At Tangsehl, the large seeded selection seems to have the same advantage with relatively early flowering and slightly later ripening, whereas the 'Tangsehl population' is ripening significantly earlier. The small seeded selection and the population under natural selection at Tangsehl, also with a significantly lower seed weight compared to the initial population, both do not show a yield advantage for this location.

Site-specific comparisons of selections and populations in Schwarze Linse reveal a similar pattern within each location. The large seeded selection gave the best yield, which was significant for seed and straw yield at Schönhagen, whereas the small seeded selection gave the lowest yield in all locations. Yield, harvest index, seed weight, ripening, and leaf size did not vary significantly between the small seeded selection and the populations in generation 0 and 10. Flowering in the 'Reinshof population' and the 'Schönhagen population' was significantly earlier compared to the initial population. For Gestreifte Linse, the large seeded selection does not differ significantly from the populations in generation 0 and 10 in all traits at each location. However, in Schönhagen, the large seeded selection and the 'Schönhagen population' provided the highest seed yield and the initial population gave the highest straw yield. Beside 
the lower seed weight across locations, the small seeded selection differed significantly with a smaller leaf size and lower yield at Reinshof and a lower seed yield at Tangsehl compared to the large seeded selection and the site-specific populations from natural selection. The flowering score sum is highest for the small seeded selection at each location and significantly different from the initial population at Schönhagen, indicating a genetic correlation of a lower seed weight with earlier flowering for this selection.

To sum up, Pisarecka Perla showed significant response to selection for large seeds in straw yield. The larger seeded populations (PP_R_10, PP_S_10) or selection (PP_large) expressed a general yield advantage in all locations. However, at Tangsehl, the small seeded selection had the second highest seed yield and the highest harvest index at Tangsehl and Schönhagen. Site-specific natural selection and the selection for small seeds in Schwarze Linse did not alter the mean performance significantly compared to the initial population, whereas selection on large seeds led to significant changes in agronomical, phenological, and morphological traits. For Gestreifte Linse, it is the selection for small seeds, which altered many traits significantly, compared to the initial population. Since natural selection did not change seed weight significantly and separation of small and large seeds by sieving resulted in either significantly larger or smaller seeds compared to the initial population in Schwarze Linse and Gestreifte Linse, respectively, it can be assumed that recombination occurred at some point during the six generations of selection and altered seed size. Since the first separation in 2000 for seed size did not result in significantly different fractions in seed weight in Schwarze Linse and Gestreifte Linse (Horneburg 2003), such a recombination, e.g. from outcrossing, must have occurred in later generations during 2006-2010.

Results from progeny testing revealed significant variation between progenies of the small seeded selection of Pisarecka Perla for most traits. In the large seeded selection, seed weight and flowering showed significant variation. In Schwarze Linse, no significant variability was observed, except for the large seeded selection for seed weight and flowering. In Gestreifte Linse, significant variation was observed for seed weight and flowering in both selections. These results indicate genetic variability especially in the small seeded selections of Pisarecka Perla and the large seeded selection of Schwarze Linse.

Genotyping by SNP marker gave a clear grouping according to selections. The visualization via the cluster dendrogram according to the minimum-variance method (Ward 1963; Ward and Hook 1963) does not allow for comparisons by genetic distances, thus clusters of selections within the same cultivar have a larger branch height and no clear clustering according to cultivar affiliation is visible. However, outliers from potential outcrossing or wrongly classified samples can be identified from this figure. Two samples of PP_large were clustered within the group of GL_large, suggesting wrong phenotypic classification. Several samples of PP_small are clustering closely with SL_large or SL_small samples, suggesting possible outcrossing between these two cultivars.

By the 'Unweighted Pair Group Method with Arithmetic mean' (UPGMA; Sokal and Michener 1958), individuals phenotypically selected and classified to either large or small seeded selections with in the same cultivar could be distinctly clustered, accordingly. In Pisarecka Perla, variability in the small seeded selection is large compared to the large seeded selection, where 30 individuals are homogenous and 10 individuals are heterogeneous. The 30 homogenous individuals correspond to genotype $A$, identified in CHAPTER 3.3, and three samples (PP_large_03, PP_large_06, PP_large_09) correspond to genotype C, identified in the initial population (FIGURE 3.15). The majority with 25 small seeded progenies correspond to genotype $B$, but recombination probably by outcrossing resulted in genetic variability. Outcrossing with 
one of the other cultivars cannot be excluded and should be further analyzed by looking on seed color of those progenies closely clustered to another cultivar. Additionally, genetic distances may be calculated. The small seeded selection of Schwarze Linse is highly homogenous, whereas the large seeded individuals are highly variable, which corresponds to the phenotypic results on variability between progenies. In Gestreifte Linse, the small seeded selection is highly variable, compared to 39 highly homogeneous large seeded individuals. Two large seeded individuals (GL_large_84 and GL_large_96) are outlying from the other 39 samples and clustered near SL_large, thus may be wrongly classified samples rather than outcrossing products due to lacking heterozygosity (7 loci are heterozygous in GL_large_96, but none of the 145 SNPs in GL_large_84).

In conclusion, genetic diversity observed within Pisarecka Perla could be maintained by selection for extreme seed sizes and yield performance was improved. Genotypic variability despite a strong selection is still present, especially within the small seeded selection, suggesting additional recombination. The risk is high to select outlying genotypes from outcrossing and the initial material may be unintentionally changed. 


\section{REFERENCES}

Al-Karaki GN (1998) Seed Size and Water Potential Effects on Water Uptake, Germination and Growth of Lentil. Journal of Agronomy and Crop Science 181:237-242. doi:10.1111/j.1439-037X.1998.tb00423.x.

Coomes DA, Grubb PJ (2003) Colonization, tolerance, competition and seed-size variation within functional groups. Trends in Ecology \& Evolution 18:283-291. doi:10.1016/S0169-5347(03)00072-7.

Eriksson O (1999) Seed size variation and its effect on germination and seedling performance in the clonal herb Convallaria majalis. Acta Oecologica 20:61-66. doi:10.1016/S1146-609X(99)80016-2.

Erskine W (1996) Seed-size effects on lentil ( Lens culinaris) yield potential and adaptation to temperature and rainfall in West Asia. The Journal of Agricultural Science 126:335-341. doi:10.1017/S002185960007489X.

Erskine W, Williams PC, Nakkoul H (1985) Genetic and environmental variation in the seed size, protein, yield, and cooking quality of lentils. Field Crops Research 12:153-161. doi:10.1016/03784290(85)90061-9.

Fedoruk MJ (2013) Linkage and association mapping of seed size and shape in lentil. M. Sc. Thesis, Saskatoon, Saskatchewan.

Fedoruk MJ, Vandenberg A, Bett KE (2013) Quantitative Trait Loci Analysis of Seed Quality Characteristics in Lentil using Single Nucleotide Polymorphism Markers. The Plant Genome 6:0. doi:10.3835/plantgenome2013.05.0012.

Galili T (2015) dendextend: an R package for visualizing, adjusting and comparing trees of hierarchical clustering. Bioinformatics (Oxford, England) 31:3718-3720. doi:10.1093/bioinformatics/btv428.

Gao X, Starmer JD (2008) AWclust: point-and-click software for non-parametric population structure analysis. BMC bioinformatics 9:77. doi:10.1186/1471-2105-9-77.

Goldringer I, Enjalbert J, Raquin A, Brabant P (2001) Strong selection in wheat populations during ten generations of dynamic management. Genet. Sel. Evol. 0:1-23.

Haig D (1989) Seed size and adaptation. Trends in Ecology \& Evolution 4:145. doi:10.1016/01695347(89)90214-0.

Halekotte M (2015, unpublished) Auswirkungen des Samengewichts auf die Jungpflanzenentwicklung von drei Linsensorten. B. Sc. Thesis, Georg-August-Universität, Göttingen.

Hamdi A, Erskine W, Gates P (1991) Relationships among economic characters in lentil. Euphytica:109116.

Hojjat SS (2011) Effect of seed size on germination and seedling growth of some Lentil genotypes (Lens culinaris Medik.). International Journal of Agriculture and Crop Science 3:1-5.

Horneburg B (2003) Standortspezifische Sortenentwicklung: Eine Studie mit Landsorten der Linse. Schriften zu Genetischen Ressourcen. Band 21.

Horneburg B, Becker HC (2008) Crop Adaptation in On-Farm Management by Natural and Conscious Selection. A Case Study with Lentil. Crop Science 48:203-212.

Sadras VO (2007) Evolutionary aspects of the trade-off between seed size and number in crops. Field Crops Research 100:125-138. doi:10.1016/j.fcr.2006.07.004. 
Sharpe AG, Ramsay L, Sanderson L, Fedoruk MJ, Clarke WE, Li R, Kagale S, Vijayan P, Vandenberg A, Bett KE (2013) Ancient orphan crop joins modern era: gene-based SNP discovery and mapping in lentil. BMC genomics 14:1-13. doi:10.1186/1471-2164-14-192.

Silvertown J (1989) The paradox of seed size and adaptation. Trends in Ecology \& Evolution 4:24-26. doi:10.1016/0169-5347(89)90013-X.

Sokal RR, Michener CD (1958) A statistical method for evaluating systematic relationships. University of Kansas Science Bulletin 38:1409-1438.

Utz HF (2011) PLABSTAT. Software for the statistical analysis of experiments in the area of plant breeding. Institut of Plant Breeding, Seed Science and Populations Genetics, Universität Hohenheim, Hohenheim.

Ward JH (1963) Hierarchical grouping to optimize an objective function. American Statistical Association Journal 426:236-244.

Ward JH, Hook ME (1963) Application of an hierarchical grouping procedure to a problem of grouping profiles. Educational and Psychological Measurement 23:69-81.

Zhong Y (2017, unpublished) Phenotypic and molecular variation in lentil populations selected for extreme seed size. M.Sc. Thesis, Georg-August-Universität, Göttingen. 


\section{RESPONSE TO DROUGHT STRESS IN POPULATIONS FROM NATURAL SELECTION}

\subsection{INTRODUCTION}

Lentil is an autogamous species with limited outcrossing (Horneburg 2006; Erskine and Muehlbauer 1991). Thus, genetic adaptation to abiotic conditions such as drought stress by natural selection may apply under the presupposition of genetic variability available within the initial material. As Imam and Allard (1965) discussed for wild populations of oats, that the combination of "the flexibility of outbreeders with some of the ability of inbreeders to maintain specific highly adapted genotypes" leads "to the success [...] in occupying complex habitats" for this species, may apply as well to the example of lentil under long-term on-farm management.

Lentil is generally relatively well adapted to dry conditions (e.g. Materne and Siddique 2009). Nevertheless, the lentil crop often experiences terminal as well as intermittent droughts throughout the growing season, which limits yield in Mediterranean-type climatic regions (Silim et al. 1993). Significant genotypic variability in root and shoot traits was observed in lentil genotypes from the Near East, Asia, and East Africa by Sarker et al. (2005). They observed significant variation for accessions from the Near East only in lateral root number and yield per plant, whereas accessions from Asia and East Africa varied significantly in taproot length and lateral root number. In conclusion, they assumed that this originates from adaptation during domestication to two different climatic environments with drought occurring during different time points in the season. South Asian genotypes revealed no significant relationship of root traits with seed yield under rain-fed conditions, but early flowering, early maturity, the biological yield, and the harvest index were identified as key traits for a higher seed yield in lentil under drought (Kumar et al. 2012). Idrissi et al. (2015) suggested selection in water-limited environments for a high root-shoot biomass ratio to improve drought tolerance and identified a Quantitative Trait Loci (QTL) explaining the highest phenotypic variance for this ratio (Idrissi et al. 2016).

Initially for this study, multiple old cultivars and landraces were screened and three of them finally selected according to distinct phenotype (growing type, seed size, seed color, flower color, etc.) between the cultivars (see CHAPTER 1.1, and 2.1-2.2). Subsequently, the three lentil cultivars were exposed to ten generations of natural selection at three sites on-farm under rain-fed conditions in Central and Northern Germany (FIGURE 1.1). Significant site-specific changes in seed weight for one cultivar and a shifted beginning of flowering in two cultivars had occurred already after four years of natural selection (Horneburg and Becker 2008). Water availability might have been one of the main factors distinguishing the selection sites, mostly due to the different soil types (

TABLE 5.1) exhibiting dissimilar physical soil structures and water holding capacities, accordingly. Soil profile descriptions were made in more detail in the M.Sc. Thesis of Bockelmann (2017, unpublished). Two of the selection sites are on 'poor or marginal soils'. At Schönhagen, it is a shallow clay on limestone on a slope, where fast desiccation after few days without precipitation could be observed. And in Tangsehl, it is a very sandy soil with an expected frequent shortage in available water for the crop. Thus, drought stress was potentially distinguishing strength and direction of natural selection between locations. In consequence, populations after ten generations of natural selection might have developed differential degrees of adaptation, response, or tolerance to drought stress conditions. 
TABLE 5.1 The three sites of selection.

\begin{tabular}{|c|c|c|c|}
\hline & Reinshof & Schönhagen & Tangsehl \\
\hline Geographical coordinates & $\begin{array}{c}51^{\circ} 29^{\prime} 50^{\prime \prime} \mathrm{N} / \\
9^{\circ} 55^{\prime} 53^{\prime \prime} \mathrm{E}\end{array}$ & $\begin{array}{c}51^{\circ} 21^{\prime} 2^{\prime \prime} \mathrm{N} / \\
10^{\circ} 0^{\prime} 44^{\prime \prime} \mathrm{E}\end{array}$ & $\begin{array}{c}53^{\circ} 10^{\prime} 31^{\prime \prime} \mathrm{N} / \\
10^{\circ} 52^{\prime} 50^{\prime \prime} \mathrm{E}\end{array}$ \\
\hline Altitude (above sea level) & $150 \mathrm{~m}$ & $330-360 \mathrm{~m}$ & $40 \mathrm{~m}$ \\
\hline Annual precipitation & $651 \mathrm{~mm}^{\text {a) }}$ & $773 \mathrm{~mm}^{\mathrm{b})}$ & $617 \mathrm{~mm}^{\mathrm{c})}$ \\
\hline Long-term mean temperature & $9.2^{\circ} \mathrm{C}^{\text {a) }}$ & $8.1^{\circ} \mathrm{C}^{\mathrm{d})}$ & $8.6^{\circ} \mathrm{C}^{\mathrm{e})}$ \\
\hline Management & conventional & bio-dynamic & bio-dynamic \\
\hline Soil type & $\begin{array}{c}\text { Loess } \\
\text { deep loam }\end{array}$ & $\begin{array}{l}\text { Leptosol } \\
\text { shallow clay on } \\
\text { limestone }\end{array}$ & $\begin{array}{c}\text { Podsol } \\
\text { glacial sand with } \\
\text { flint stones }\end{array}$ \\
\hline Soil value (Ackerzahl) & $82-90$ & $23-30$ & $33-36$ \\
\hline Humus content [\%] & 2.0 & 4.2 & 1.8 \\
\hline $\mathrm{pH}$-value $(\mathrm{CaCl})$ & 7.0 & 7.5 & 5.0 \\
\hline P2O5 [mg 100g-1 soil] & 5.2 & 1.2 & 3.8 \\
\hline $\mathrm{K} 2 \mathrm{O}\left[\mathrm{mg} 100 \mathrm{~g}^{-1}\right.$ soil $]$ & 20 & 17 & 14 \\
\hline \multicolumn{4}{|c|}{ a) Long-term mean (1981-2010) of the meteorological station Göttingen, Deutscher Wetterdienst. } \\
\hline \multicolumn{4}{|c|}{ b) Long-term mean (1981-2010) of the meteorological station Bad Sooden, Allendorf, Deutscher Wetterdienst } \\
\hline \multicolumn{4}{|c|}{ c) Long-term mean (1989-1999) at the farm station Tangsehl } \\
\hline \multicolumn{4}{|c|}{ d) Long-term mean (1981-2010) of the meteorological station Leinefelde, Deutscher Wetterdienst } \\
\hline \multicolumn{4}{|c|}{ e) Long-term mean (1961-1990) of the meteorological station Lüchow, Wendland, Deutscher Wetterdienst } \\
\hline & Adapted from $\mathrm{TA}$ & 1 ; modified and updat & from Horneburg (2003 \\
\hline
\end{tabular}

To study adaptation to drought stress, phenological and morphological traits, such as flowering and leaf size, were assessed additional to the agronomical traits, as seed and straw yield and harvest index, which may give a hint on the physiological mechanisms behind different yield responses between cultivars and between populations within cultivars. Furthermore, since site-specific changes in seed weight and flowering time were observed, phenotypical assessments may reveal if these changes are an adaptation to drought stress or if rather other factors were responsible for these shifts in phenological and morphological traits.

Mainly two indirect methods, complementary to phenotypical assessments on the plant in the field, are suggested in the literature, which are widely used in drought stress research with plants. Canopy temperature measured by thermal infrared imaging as a quick, cheap, and easy remote sensing technique (Mason and Singh 2014). Carbon isotope discrimination of the naturally abundant isotope ${ }^{13} \mathrm{C}$ and ${ }^{12} \mathrm{C}$, as a second method, is more sophisticated to measure and requires expensive technical lab equipment and thoroughly prepared samples for the analysis.

Leaf-canopy temperature is related to plant water stress. This was shown in a large number of studies in different crops (e.g. Wiegand and Namken 1966; Ehrler and van Bavel 1967; Aston and van Bavel 1972). Significant negative correlations of canopy temperature with soil moisture (Patel et al. 2001), evapotranspiration (Saha et al. 1986), and leaf water potential (Blum et al. 1982) were observed in pigeonpea, chickpea, and wheat, respectively. Patel et al. (2001) showed negative correlations of canopy temperature based indices with pods per plant and seed yield throughout the phenological stages from flowering to grain filling and maturity. Under greenhouse conditions in an experiment with beans and lupins, Grant et al. (2006) were able to detect differences between water-deficit and well-watered conditions by canopy thermal imaging at about the same time as with other conventional, more direct methods. Consequently, the conclusions given in the aforementioned studies are in favor of thermal 
remote sensing as a valuable method to monitor canopy temperature for the estimation of crop water relations. Nevertheless, employing thermal infrared imaging on crop canopies as a remote diagnosis in the field is sensitive to non-homogeneous conditions during the measurement, as canopy temperature is influenced by many environmental factors, such as air temperature, wind, humidity etc., as well as by the canopy structure of the crop stand itself (Jones et al. 2009).

Drought stress is a complex trait which comprises many physiological processes. Thus, the approach of measuring the useful surrogate variables of natural abundant carbon as $\delta^{13} \mathrm{C}$ by mass spectrometry may be one solution to quantify and understand the general response of plants to stress factors (Robinson 2000). From the $\delta{ }^{13} \mathrm{C}$ value, Farquhar and Richards (1984) calculated $\Delta{ }^{13} \mathrm{C}$ by taking the ${ }^{13} \mathrm{C} /{ }^{12} \mathrm{C}$ ratio of atmospheric $\mathrm{CO}_{2}$ into account, which correlated with water-use efficiency of wheat genotypes. They suggested the carbon-isotope analysis as "a useful tool in selection for improved water-use efficiency". Under drought stress, a reduced transpiration rate leads to reduced isotope discrimination and subsequently higher values of $\Delta{ }^{13} \mathrm{C}$ compared to well-watered conditions.

To study the response to drought under field conditions, we induced drought stress by covering the field plots after sowing with rainout shelters. Comparing between frequently irrigated and desiccated field plots, we aim to answer the question, if drought stress played a significant role during site-specific population development by natural selection and led to a site-specific drought tolerance. 


\subsection{MATERIALS AND METHODS}

\section{Plant MATERIAL}

Three old lentil cultivars were exposed to ten generations of natural selection at three farms under rainfed conditions in Central and Northern Germany. For this study, the nine populations (three cultivars $x$ three selection sites) after ten generations of natural selection were tested in field plots in rainout shelters under irrigated and dry conditions. Seeds harvested in 2010 at the sites of selection were used to establish the experiment in 2014. In 2015 and 2016, seeds obtained from homogeneous multiplication in 2014 (see CHAPTER 2.2) was used.

\section{FIELD EXPERIMENT - CONDITIONS AND MANAGEMENT}

The experiment was repeated during three seasons in 2014, 2015, and 2016 at Reinshof, Göttingen (TABLE 5.2, FigURE 5.1). After the preceding crop (winter wheat) the field was plowed before winter; fertilizers were not applied. At the day of sowing, the seed-bed preparation was done with a rotary harrow. In 2016, one herbicide application (Bandur ${ }^{\circledR}$ ) was conducted two days after sowing.

Seeds were sown approximately $4 \mathrm{~cm}$ deep in soil with a plot seeder with 100 seeds $\mathrm{m}^{-2}$ and row width of $0.24 \mathrm{~m}$ in mid of April in six-row plots of $5 \mathrm{~m}^{2}(1.5 \times 3.3 \mathrm{~m})$. Plots were arranged in a split-split-plot design with four replications. In this design, treatments (irrigation regime) were taken as the main blocks, cultivars were sub-blocks randomized within each treatment, and selections were randomized as sub-sub-plots within cultivars. In this way, selections within each cultivar are grown next to each other.

After field emergence, around three weeks past sowing, field plots were covered by two $360 \mathrm{~m}^{2}(10 \mathrm{~m} \mathrm{x}$ $36 \mathrm{~m}$ ) rainout shelters (TABLE 5.4). Both shelters were installed next to each other and were divided into two treatments hosting two replications each. In total, the two shelters had the capacity of 96 field plots: 36 experimental plots per shelter testing nine test entries (three cultivars $x$ three selections), in two treatments. Two border plots on each head end of the shelters and two border plots in the middle of the shelters were installed to separate the treatments from each other and to minimize border effects.

Irrigation was done on a weekly basis with about 13-15mm per week during 7-9 weeks (TABLE 5.4) starting before flowering until the end of grain filling stage by drip irrigation tubes. Dry plots were rain-fed before covered and never irrigated afterwards, except one block in one of the shelters in 2014, which was irrigated once in the beginning of June to homogenize the treatment after surface water entered selectively during heavy rainfalls on $12^{\text {th }}$ of June (FIGURE 5.1).

Soil water content was measured gravimetrically from soil samples taken on a weekly basis before irrigating. Soil samples were taken using the three-part hand drilling system ("Göttinger Bohrstöcke", Bodenprobetechnik Nietfeld $\mathrm{GmbH}$, Quakenbrück), which allows to obtain three separate samples of 30 $\mathrm{cm}$ depth each, down to $90 \mathrm{~cm}$ below surface. Sampling was done in the center of each replication, adding up to four sampling points per treatment and shelter. Soil samples were dried at $105^{\circ} \mathrm{C}$ for at least $12 \mathrm{~h}$.

Climatic conditions, especially the distribution of precipitation, differs between the years (FIGURE 5.1, TABLE 5.3). The total amount of precipitation in April 2014 is significantly lower compared to April 2015 (TABLE 5.3). However, the distribution of rainfall is superior in April 2014, compared to April 2015, where after a long period of no or very limited rainfall, first rainfalls occurred about one week after sowing (FIGURE 5.1), thus delaying germination. Temperature and sunshine duration are expected to be the main climatic parameters triggering plant growth in the sheltered plots. For May until July, monthly mean temperatures 
are similar in 2014 and 2015, in 2016 May and June they are on average 1.6 and $1.8^{\circ} \mathrm{C}$ higher (TABLE 5.3). Sunshine duration over the whole growing season is highest in 2015 and lowest in 2014.

TABLE 5.2 Soil conditions before sowing in March at the experimental location Reinshof.

\begin{tabular}{|c|c|c|c|}
\hline & \multicolumn{3}{|c|}{ Year } \\
\hline & 2014 & 2015 & 2016 \\
\hline Soil value (Ackerzahl) & 93 & $72-79$ & $72-79$ \\
\hline $\mathrm{pH}(\mathrm{CaCl})$ & 7.2 & 7.1 & 6.7 \\
\hline $\mathrm{P}_{2} \mathrm{O}_{5}\left[\mathrm{mg} 100 \mathrm{~g}^{-1}\right.$ soil $]$ & 6.1 & 7.1 & 4.5 \\
\hline $\mathrm{K}_{2} \mathrm{O}\left[\mathrm{mg} 100 \mathrm{~g}^{-1}\right.$ soil $]$ & 10.5 & 14.3 & 12.8 \\
\hline $\mathrm{Mg}\left[\mathrm{mg} 100 \mathrm{~g}^{-1}\right.$ soil $]$ & 8.0 & 8.5 & 8.0 \\
\hline $\mathrm{N}_{\min }\left[\mathrm{kg} \mathrm{N} \mathrm{ha} \mathrm{a}^{-1}\right]$ & 16 & 17 & 7 \\
\hline \multirow[t]{2}{*}{ in depth $0-30,30-60,60-90 \mathrm{~cm}$ (top down) } & 18 & 14 & 14 \\
\hline & 19 & 19 & 19 \\
\hline
\end{tabular}

TABLE 5.3 Climatic conditions in the three subsequent years during the season of trials at Reinshof.

\begin{tabular}{|c|c|c|c|c|c|c|c|}
\hline & Year & Apr & May & Jun & Jul & Aug & $\begin{array}{r}\text { Mean }\left[{ }^{\circ} \mathrm{C}\right] / \text { Sum } \\
{[\mathrm{mm}],[\mathrm{h}]} \\
\end{array}$ \\
\hline \multirow[t]{3}{*}{$\begin{array}{l}\text { Mean temperature } \\
{\left[{ }^{\circ} \mathrm{C}\right]}\end{array}$} & 2014 & 11.4 & 12.7 & 15.2 & 19.1 & 15.9 & 14.9 \\
\hline & 2015 & 8.4 & 12.2 & 15.4 & 18.7 & 19.6 & 14.8 \\
\hline & 2016 & 8.1 & 13.8 & 17.2 & 18.6 & 17.9 & 15.1 \\
\hline \multirow[t]{3}{*}{ Precipitation [mm] } & 2014 & 22.9 & 103.6 & 73.8 & 105.5 & 98.4 & 404 \\
\hline & 2015 & 46.5 & 30 & 23.1 & 91 & 113.7 & 304 \\
\hline & 2016 & 28.4 & 41.4 & 113 & 43 & 40.5 & 266 \\
\hline \multirow[t]{3}{*}{$\begin{array}{l}\text { Sunshine duration } \\
\text { [h] }\end{array}$} & 2014 & 140.5 & 191.6 & 192.3 & 220.8 & 149.2 & 894 \\
\hline & 2015 & 212.2 & 190.3 & 184.8 & 217 & 234.2 & 1039 \\
\hline & 2016 & 153.1 & 211 & 192.4 & 169.5 & 220.6 & 947 \\
\hline
\end{tabular}

TABLE 5.4 Drought stress experiment management dates.

\begin{tabular}{|c|c|c|c|c|c|c|c|}
\hline \multirow[t]{2}{*}{ Year } & \multirow[t]{2}{*}{$\begin{array}{l}\text { Sowing } \\
\text { date }\end{array}$} & \multicolumn{2}{|c|}{ Harvest date } & \multicolumn{2}{|c|}{$\begin{array}{l}\text { Season length (days } \\
\text { planting to harvest) }\end{array}$} & \multirow[t]{2}{*}{$\begin{array}{l}\text { Sheltered } \\
\text { since }\end{array}$} & \multirow{2}{*}{$\begin{array}{l}\text { Irrigation } \\
\text { (weeks; } \\
\text { total } \mathrm{mm} \text { ) }\end{array}$} \\
\hline & & dry & irrigated & dry & irrigated & & \\
\hline 2014 & 15. April & $\begin{array}{l}24 . \\
\text { July }\end{array}$ & 12. / 18. Aug. & 100 & $119 / 125$ & 6. / 15. May & $7 ; 100$ \\
\hline 2015 & 13. April & $\begin{array}{l}22 . \\
\text { July }\end{array}$ & 8. August & 100 & 117 & 11. May & $8 ; 119$ \\
\hline 2016 & 12. April & $\begin{array}{l}25 . \\
\text { July }\end{array}$ & 3. August & 104 & 113 & 4. / 6. May & 9; 117 \\
\hline
\end{tabular}



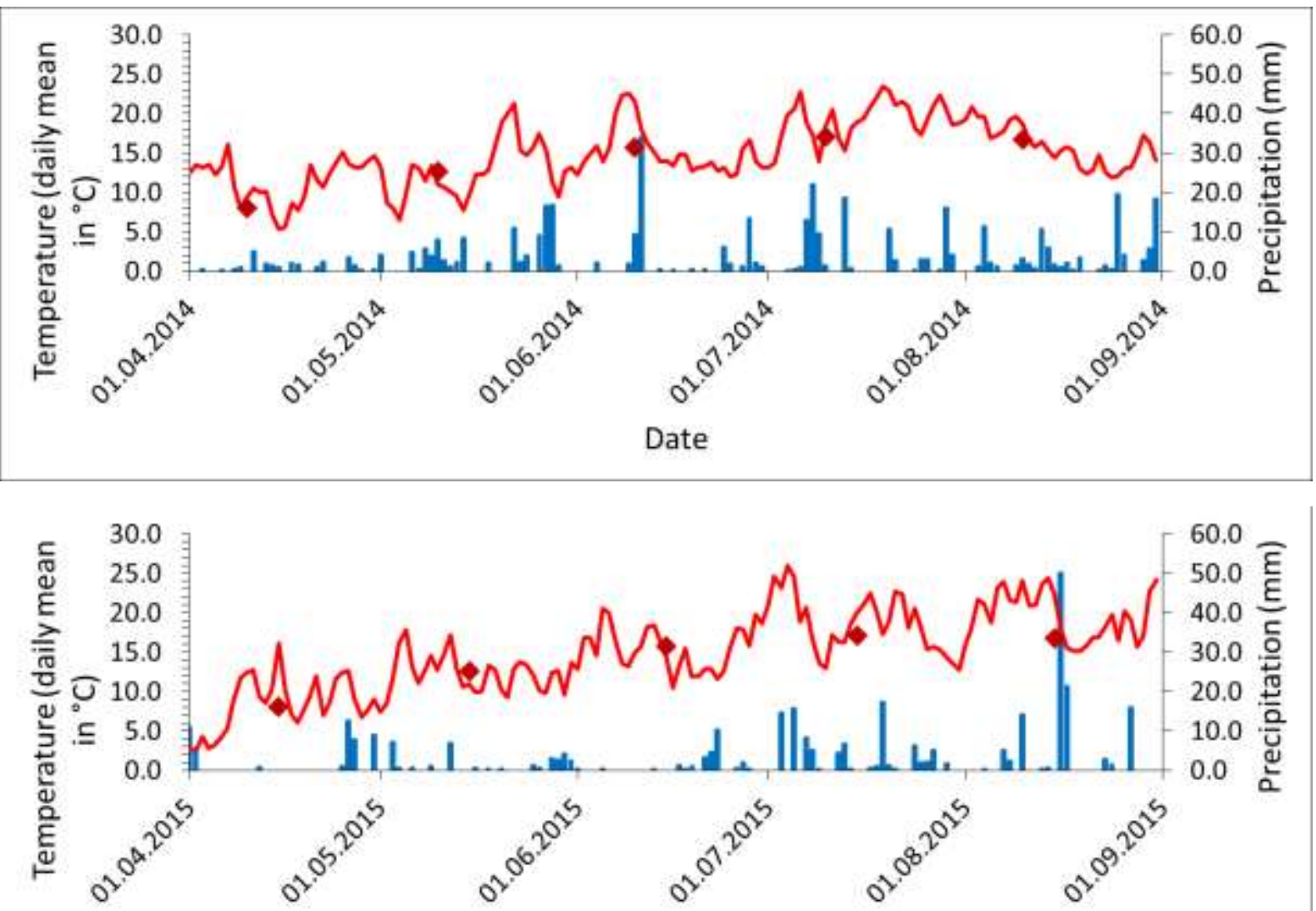

Date

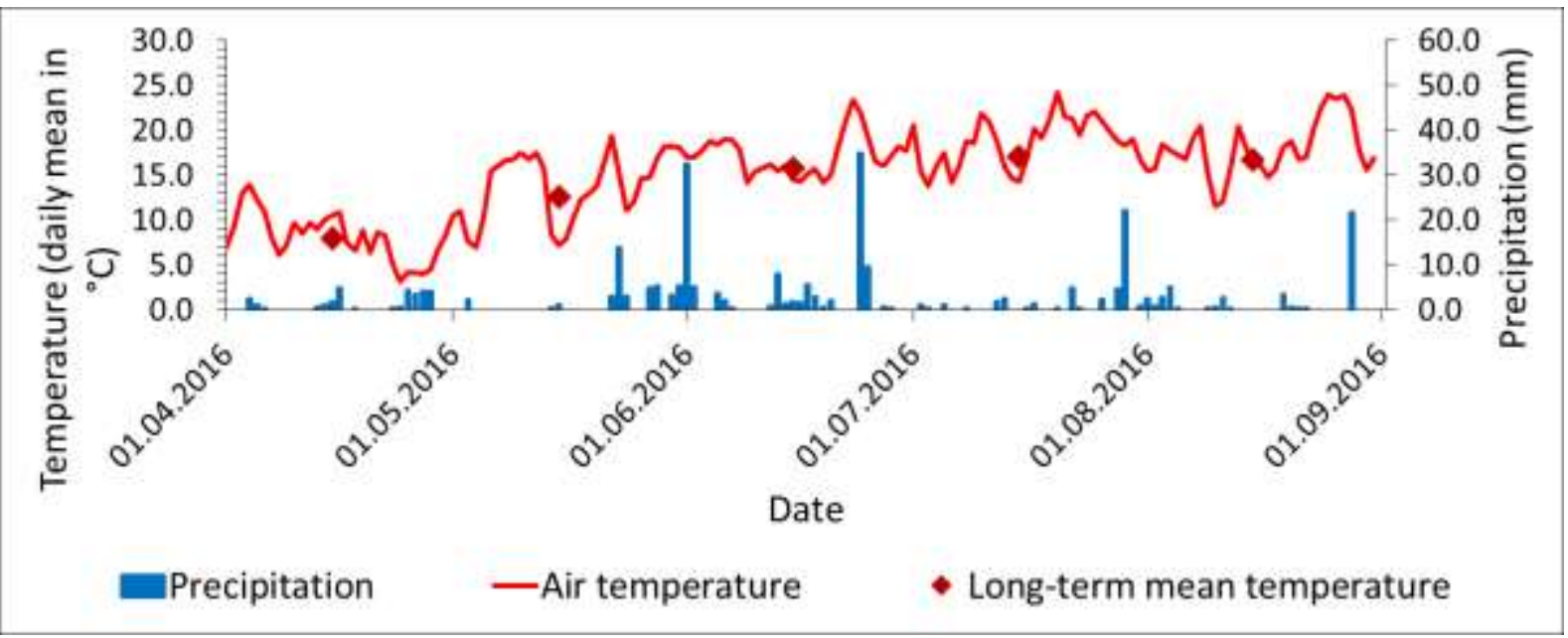

FIGURE 5.1 Climatic conditions in 2014, 2015, and 2016 from April to August at Reinshof.

Data source: Meteorological station Göttingen, Deutscher Wetterdienst (www.dwd.de/WESTE) 


\section{PhenOtYPing}

Field emergence and the number of survived, seed-bearing plants were counted in the inner $1 \mathrm{~m}^{2}$ of each plot two weeks after sowing and at harvest, respectively, and subsequently the survival rate in percentage was calculated. The whole plot was harvested by hand and whole plants were put into sacks and dried at the farm on a hot air dryer at $25-30^{\circ} \mathrm{C}$. Seed and straw weight was taken when threshing dried plants. Threshing was done by a non-mobile thresher (Pelz K35, Wachtberg-Villip, Germany). Seed and straw yield was then calculated and corrected to $86 \%$ dry matter content. The total harvest weight of either straw or seeds are multiplied by the actual total dry matter content (TDMC) and then divided by $86 \%$ dry matter content:

$$
\text { yield }(\text { seed or straw })=\frac{\text { total harvest weight } \times T D M C(=100-\text { actual water content })}{86}
$$

TDMC of seed and straw was obtained from samples by drying them at $105^{\circ} \mathrm{C}$ for $12 \mathrm{~h}$. Samples were taken from one same genotype in each replication and treatment as a standard. Seed weight was obtained by counting 4 × 100 seeds from each plot.

Seed yield per plant was calculated by dividing the obtained seed yield [ $\mathrm{gm}^{-2}$ ] by the number of plants at harvest in the inner $1 \mathrm{~m}^{2}$ of each plot. Number of seeds per plant was calculated by dividing the seed yield per plant by the seed weight.

Leaf area was measured on five (2014) or ten (2015 and 2016) leafs per plot with the 'LI-3100 C' area meter (LI-COR Biosciences) after flowering at the beginning of July.

Flowering was scored, according to Horneburg (2003), on a scale from $0-4(0 \%,>0 \leq 1 \%,>1 \leq 10 \%$, up to $50 \%$, and $>50 \%$ of the plants flowering) starting when first flowers were observed continuously every second day until full flowering was reached.

Lodging and ripening was scored once during the season, when the respective trait was well pronounced, e.g. after a strong wind event or at visible differential ripening of genotypes, on a scale from 1-9, from lowest to complete peculiarity of the trait.

Thermal infrared imaging (Thermacam FLIR T640, FLIR Systems, Inc., Wilsonville, OR, USA) was done at individual dates from June until beginning of July, during full flowering and subsequent grain filling stage, at conditions of clear sky and sunshine between 11 a.m. and 2 p.m. standard time.

Seed samples for isotopic analysis on carbon were taken after threshing in 2014. In 2015 additionally to seeds, also straw samples were taken when threshing and a midterm plant harvest of five random branches was done during grain filling stage on $6^{\text {th }}$ of July. Samples were dried at $60^{\circ} \mathrm{C}$ and milled to a fine powder by a ball mill (Retsch MM 400) for 25-45 sec, depending on the sample type. $1.8 \mathrm{mg}( \pm 10 \%$ ) of each of the dried and milled samples were placed in tin capsules (IVA Analysentechnik, Meerbusch, Germany) for combustion and $\delta^{13} \mathrm{C}$ values of samples were analyzed for isotopic composition with a Finnigan MAT Delta C mass spectrometer (ThermoFinnigan, Bremen, Germany) coupled to an elemental analyzer 1108 (Carlo-Erba, Milan, Italy), as described in Senbayram et al. (2015) and Brueck and Senbayram (2009). Subsequently, $\Delta{ }^{13} \mathrm{C}$ is calculated according to Farquhar and Richards (1984):

$$
\Delta{ }^{13} \mathrm{C}=\left[\left(\mathrm{R}_{\mathrm{a}} / \mathrm{R}_{\mathrm{p}}\right)-1\right] * 1000,
$$

with $R_{a}$ being the ${ }^{13} C /{ }^{12} \mathrm{C}$ ratio of the atmospheric $\mathrm{CO}_{2}$ and $\mathrm{R}_{\mathrm{p}}$ being the ${ }^{13} \mathrm{C} /{ }^{12} \mathrm{C}$ ratio of biomass carbon. 


\section{STATISTICAL ANALYSIS}

Analysis of variance (ANOVA) was done with the software PLABSTAT (Version 3Bwin, Utz 2011). Analysis of 'Additive Main effects and Multiplicative Interaction' (AMMI) was done on the statistical platform ' $R$ Studio' (Version 1.0.136; RStudio Team 2015) using the function 'AMMI()' from the package 'agricolae' developed by Mendiburu (2016).

The following models for ANOVA were applied according to the split-plot field design:

For the analysis of the effects of year, treatment across year, cultivar across treatment and year, and selection across cultivar, treatment and year:

$$
\begin{aligned}
x_{i j k l m}=\mu+y_{i} & +r_{m}+y r_{i m}+t_{j}+y t r_{i j m}+c_{k}+y t c r_{i j k m}+s_{l}+y t c s r_{i j k l m} \\
& +y t_{i j}+y c_{i k}+y s_{i l}+t c_{j k}+t s_{j l}+c s_{k l}+y t c_{i j k}+y t s_{i j l}+y c s_{i k l}+t c s_{j k l}+y t c s_{i j k l}
\end{aligned}
$$

where $x_{i j k l m}$ is the observed value, $\mu$ is the general mean of the experiment, and $y_{i}, t_{j}, c_{k}, s_{l}$ and $r_{m}$ are the effects of year, treatment, cultivar, selection, and the replication, respectively, and $\mathrm{ytcsr}_{\mathrm{ijk}} \mathrm{m}$ is the residual error, followed by all possible interactions. Replication and year, when involved, were taken as random factors in the model.

For the analysis of the effect of treatment within years, cultivar across treatment, and selection across cultivar and treatment, with $t_{c s} r_{j k l m}$ being the residual error:

$$
\mathrm{x}_{\mathrm{jklm}}=\mu+\mathrm{t}_{\mathrm{j}}+\mathrm{r}_{\mathrm{m}}+\mathrm{tr}_{\mathrm{jm}}+\mathrm{c}_{\mathrm{k}}+\mathrm{tcr}_{\mathrm{jkm}}+\mathrm{s}_{\mathrm{l}}+\mathrm{tcsr}_{\mathrm{jklm}}+\mathrm{tc} \mathrm{c}_{\mathrm{jk}}+\mathrm{ts} \mathrm{s}_{\mathrm{jl}}+\mathrm{cs}_{\mathrm{kl}}+\mathrm{tcs} \mathrm{s}_{\mathrm{jkl}}
$$

For the analysis of the effect of treatment within cultivar across year and selection across treatment and year, with ytsr $r_{i j m}$ being the residual error:

$$
x_{i j l m}=\mu+y_{i}+r_{m}+y r_{i m}+t_{j}+y t r_{i j m}+s_{1}+y t s r_{i j \mid m}+y t_{i j}+y s_{i l}+t s_{j l}+y t s_{i j l}
$$

For the analysis of the effect of cultivar within treatment across year and the effect of selection across cultivar and year, with ycsr $r_{i k l m}$ being the residual error:

$$
x_{i k l m}=\mu+y_{i}+r_{m}+y r_{i m}+c_{k}+y c r_{i k m}+s_{l}+y c s r_{i k l m}+y c_{i k}+y s_{i k l}+c s_{k l}+y c s_{i k l}
$$

For the analysis of effects of cultivar within treatment and single year, and the effect of selection across year and cultivar, e.g. for traits taken only in one individual year, with $\operatorname{csr}_{\mathrm{klm}}$ being the residual error:

$$
x_{k l m}=\mu+c_{k}+r_{m}+c r_{k m}+s_{l}+c s r_{k l m}+c s_{k l}
$$

For the analysis of the effect of selection within cultivar and treatment across years, with ysrilm being the residual error:

$$
x_{i l m}=\mu+y_{i}+r_{m}+y r_{i m}+s_{1}+y s r_{i l m}+y s_{i l}
$$

For the analysis of single year data for the effect of selection within treatment and cultivar:

$$
x_{I m}=\mu+s_{I}+r_{m}+s r_{I m}
$$




\subsection{RESULTS}

\section{SOIL WATER CONTENT}

Reduction in soil water content over time in non-irrigated plots was similar during the first two seasons $(2014,2015)$ in the upper soil layer $(0-30 \mathrm{~cm})$, while in 2016 a higher soil water content was measured throughout the season in the first layer $(0-30 \mathrm{~cm}$ ) (data not shown). Absolute differences (irr. - dry) were still smaller in the mid and end of June 2016 compared to 2014 and 2015 (TABLE 5.5). Nevertheless, in the deeper soil $(30-60 \mathrm{~cm})$ in the dry treatment a lower soil water content could still be observed compared to irrigated treatment with some fluctuation between dates. Further down to $90 \mathrm{~cm}$ depth, fluctuations were even stronger, however soil water content was still lower in dry plots for most dates.

TABLE 5.5 Absolute differences in soil water content [\%] between dry and irrigated plots measured during three seasons at three depths.

\begin{tabular}{ccccccc}
\hline \multirow{2}{*}{ Depth [cm] } & Year & Date $^{\text {a) }}$ & 28. May - 2. June & 12. - 15. June & 27. - 30. June & 4. - 7. July \\
\hline $0-30$ & 2014 & & 0.5 & 1.8 & 2.0 & 2.7 \\
& 2015 & & 1.3 & 1.8 & 2.4 & 1.7 \\
& 2016 & & 1.6 & 1.3 & 1.8 & 2.6 \\
& & Mean & 1.2 & 1.6 & 2.1 & 2.4 \\
\hline $30-60$ & 2014 & & -0.1 & 4.0 & 2.2 & 1.5 \\
& 2015 & & 1.3 & 1.6 & 1.2 & 0.8 \\
& 2016 & & 2.8 & 2.1 & 2.1 & 3.3 \\
& & Mean & 1.4 & 2.6 & 1.8 & 1.8 \\
\hline $60-90$ & 2014 & & -0.1 & 2.9 & 0.8 & 1.8 \\
& 2015 & & -0.2 & 0.9 & -0.4 & 0.0 \\
& 2016 & & 1.1 & 0.2 & 0.6 & 1.6 \\
& & Mean & 0.3 & 1.3 & 0.3 & 1.1 \\
\hline a) Exact dates differ between yers within the given period & & & &
\end{tabular}

a) Exact dates differ between years within the given period 


\section{AGRONOMIC TRAITS}

The overall mean for seed yield was highest in 2014 with $284 \mathrm{gm}^{-2}$ and $198 \mathrm{gm}^{-2}$ in irrigated and dry treatment, respectively, and lowest in 2015 with $233 \mathrm{gm}^{-2}$ and $155 \mathrm{gm}^{-2}$. Relative seed yields are 70, 67, and $75 \%$ from the dry plots compared to the irrigated plots during the three subsequent years 2014, 2015, and 2016. Total yield (seed + straw yield) across treatments was highest in $2016\left(571 \mathrm{gm}^{-2}\right)$ and lowest in $2014\left(515 \mathrm{gm}^{-2}\right)$. Comparing the three cultivars, highest yield depression for seeds was observed in Schwarze Linse, the cultivar with the lowest yield potential in both treatments (TABLE 5.6). The highest general yield potential was observed for Gestreifte Linse. For Pisarecka Perla, yields are intermediate and exhibit a lower yield depression in seed, straw, and total yield compared to the other cultivars. Higher yield depression for straw compared to seed yield can be observed in Pisarecka Perla and Gestreifte Linse, whereas in Schwarze Linse we found the opposite situation. Consequently, the harvest index increased in these two cultivars for $8 \%$ and $5 \%$, respectively, while it decreased in Schwarze Linse with $5 \%$ by the dry treatment. F-values for the treatment effects are higher for straw and total yield compared to seed yield in all cultivars, but significant with $\mathrm{P}=0.05$ for the three traits. Non-significant treatment effects or effects with a low significance level $(\mathrm{P}=0.1$ or $\mathrm{P}=0.2$ ) are found for harvest index, seed weight, seed yield per plant, and seeds per plant; exceptions are present in Gestreifte Linse (seed weight) and Schwarze Linse (seed yield per plant, seeds per plant), where treatment effects are significant with $P=0.05$. On a low ( $P=0.1$ for straw and total yield) to very low ( $\mathrm{P}=0.2$ for seed yield, seed weight, seed yield per plant, and seeds per plant) significance level, relative values for yield related traits differ between cultivars.

TABLE 5.6 Mean values (2014-2016) of agronomic traits of three cultivars in irrigated and dry treatment.

\begin{tabular}{|c|c|c|c|c|c|c|c|c|c|c|c|c|c|c|c|}
\hline \multirow{2}{*}{$\begin{array}{l}\text { Cultivar } \\
\text { Treatment } \\
\text { Trait }^{\mathrm{a})}\end{array}$} & \multicolumn{4}{|c|}{ Pisarecka Perla } & \multicolumn{4}{|c|}{ Schwarze Linse } & \multicolumn{4}{|c|}{ Gestreifte Linse } & \multirow[b]{2}{*}{$F^{d)}$} & \multicolumn{2}{|c|}{ Mean } \\
\hline & irr. & dry & rel. $\%$ b) & $\mathrm{F}^{\mathrm{c})}$ & irr. & dry & rel.\% & $\mathrm{F}^{\mathrm{c})}$ & irr. & dry & rel.\% & $\mathrm{F}^{\mathrm{c})}$ & & irr. & dry \\
\hline $\mathrm{KY}\left[\mathrm{gm}^{-2}\right]$ & 230 & 183 & 80 & $28.9 *$ & 224 & 141 & 63 & $62.0^{*}$ & 309 & 213 & 69 & $22.3^{*}$ & $2.74^{x}$ & 254 & 179 \\
\hline $\mathrm{SY}\left[\mathrm{gm}^{-2}\right]$ & 396 & 272 & 69 & $46.6^{*}$ & 347 & 232 & 67 & $538 * *$ & 436 & 267 & 61 & $113^{* *}$ & $4.37^{+}$ & 393 & 257 \\
\hline $\mathrm{TY}\left[\mathrm{gm}^{-2}\right]$ & 626 & 455 & 73 & $57.9 *$ & 569 & 372 & 66 & $254^{* *}$ & 745 & 480 & 64 & $277^{* *}$ & $5.48^{+}$ & 647 & 436 \\
\hline $\mathrm{HI}$ & 0.37 & 0.40 & 108 & $4.0^{x}$ & 0.39 & 0.37 & 95 & $8.34^{x}$ & 0.42 & 0.44 & 105 & 1.34 & 1.94 & 0.39 & 0.40 \\
\hline SW [mg] & 53.4 & 51.1 & 96 & $6.1^{x}$ & 23.9 & 23.2 & 97 & 0.44 & 35.2 & 32.2 & 91 & $22 *$ & $3.57^{x}$ & 37.5 & 35.5 \\
\hline $\mathrm{KY}_{\text {plant }}^{-1}[\mathrm{~g}]$ & 2.7 & 2.2 & 82 & $8.2^{+}$ & 2.7 & 1.7 & 63 & $832^{* *}$ & 3.8 & 2.6 & 70 & $15.8^{+}$ & $2.59^{x}$ & 3.1 & 2.2 \\
\hline Seeds plant ${ }^{-1}$ & 51 & 44 & 86 & 3.4 & 111 & 72 & 64 & $71.8^{*}$ & 106 & 81 & 76 & $12.6^{+}$ & $3.12^{x}$ & 89 & 66 \\
\hline $\begin{array}{l}\text { a) Seed yield = } \\
\text { b) Relative yield } \\
\text { c) F-values with } \\
* *, *,+{ }^{*} \text { x for } P \\
\text { d) F-values with } \\
* *, *,+, \times \text { for } P\end{array}$ & $\begin{array}{l}\text { straw } \\
\text { \%] for o } \\
\text { gnifica } \\
\text { alues = } \\
\text { gnifica } \\
\text { alues = }\end{array}$ & $\begin{array}{l}\text { eld }=5 \\
\text { treat } \\
\text { leve } \\
01,0 . \\
\text { e leve } \\
01,0\end{array}$ & $\begin{array}{l}\text {; total yi } \\
\text { ient com } \\
\text { for treat } \\
5,0.1,0 \text {. } \\
\text { for the } \\
5,0.1,0 .\end{array}$ & $\begin{array}{l}\mathrm{d}=\mathrm{TY} ; \\
\text { ared to } \\
\text { lent in } \\
\text { respec } \\
\text { fect of } \\
\text { respec }\end{array}$ & $\begin{array}{l}\text { arvest } \\
\text { rigate } \\
\text { vOVA } \\
\text { vely } \\
\text { e culti } \\
\text { vely }\end{array}$ & $\begin{array}{l}\text { dex }= \\
\text { the } F \\
\text { ron } r\end{array}$ & $\begin{array}{l}\text { seed } \\
\text { st (DF-r } \\
\text { tive va }\end{array}$ & $\begin{array}{l}\text { ight }=S \\
m .=1, D \\
\text { es [\%] (F }\end{array}$ & -deno & $\begin{array}{l}=2) \text { : } \\
\text { NOV }\end{array}$ & 110 & I. & ont & & \\
\hline
\end{tabular}


TABLE 5.8 ANOVA results for seed yield in dry and irrigated treatment and for relative yield.

\begin{tabular}{|c|c|c|c|c|c|c|c|c|}
\hline \multicolumn{9}{|c|}{ Dry treatment } \\
\hline Source ${ }^{a)}$ & DF & SS & MS & Var.cp & $\mathrm{s}(\mathrm{V} . \mathrm{cp})$ & $\mathrm{F}^{\mathrm{b})}$ & s.e. & LSD5 \\
\hline$Y$ & 2 & 35946 & 17973 & 452 & 354 & $10.57 * *$ & 6.87 & 21.98 \\
\hline $\mathrm{R}: \mathrm{Y}$ & 9 & 15300 & 1700 & 68 & 89 & 1.57 & 10.98 & 32.63 \\
\hline $\mathrm{C}$ & 2 & 96241 & 48121 & 970 & 969 & $3.64^{x}$ & 19.16 & 75.23 \\
\hline $\mathrm{CY}$ & 4 & 52859 & 13215 & 1011 & 636 & $12.18^{* *}$ & 9.51 & 28.25 \\
\hline $\mathrm{RC}: \mathrm{Y}$ & 18 & 19534 & 1085 & 199 & 119 & $2.23 *$ & 12.75 & 36.21 \\
\hline $\mathrm{S}$ & 2 & 1847 & 923 & 10 & 20 & 1.59 & 4.01 & 15.76 \\
\hline SY & 4 & 2320 & 580 & 8 & 29 & 1.19 & 6.37 & 18.11 \\
\hline SC & 4 & 496 & 124 & -18 & 14 & 0.37 & 5.3 & 17.28 \\
\hline SCY & 8 & 2696 & 337 & -38 & 45 & 0.69 & 11.04 & 31.36 \\
\hline \multirow[t]{2}{*}{ RSC:Y } & 50 & 24381 & 488 & 488 & 96 & & & \\
\hline & & & & & Heri & ability for & $=72.5(\mathrm{~s}$ & 25.07) \\
\hline \multicolumn{9}{|c|}{ 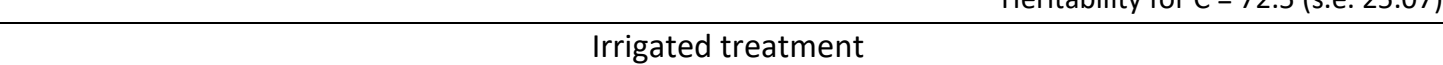 } \\
\hline Source ${ }^{a)}$ & DF & SS & MS & Var.cp & $s(V . c p)$ & $\mathrm{F}^{\mathrm{b})}$ & s.e. & LSD5 \\
\hline $\mathrm{Y}$ & 2 & 55330 & 27665 & 682 & 545 & $8.90^{* *}$ & 9.29 & 29.73 \\
\hline $\mathrm{R}: \mathrm{Y}$ & 9 & 27990 & 3110 & 143 & 161 & 1.7 & 14.24 & 42.31 \\
\hline $\mathrm{C}$ & 2 & 162790 & 81395 & 2058 & 1603 & $11.13^{*}$ & 14.26 & 55.98 \\
\hline $\mathrm{CY}$ & 4 & 29264 & 7316 & 458 & 355 & $4.01 *$ & 12.33 & 36.64 \\
\hline $\mathrm{RC}: \mathrm{Y}$ & 18 & 32844 & 1825 & 114 & 215 & 1.23 & 22.24 & 63.11 \\
\hline$S$ & 2 & 616 & 308 & -15 & 15 & 0.36 & 4.87 & 19.12 \\
\hline SY & 4 & 3413 & 853 & -53 & 47 & 0.58 & 11.12 & 31.56 \\
\hline $\mathrm{SC}$ & 4 & 1785 & 446 & -232 & 122 & 0.14 & 16.4 & 53.47 \\
\hline SCY & 8 & 25807 & 3226 & 436 & 368 & $2.17^{*}$ & 19.26 & 54.66 \\
\hline \multirow[t]{2}{*}{ RSC:Y } & 52 & 77156 & 1484 & 1484 & 286 & & & \\
\hline & & & & & & \multicolumn{3}{|c|}{ Heritability for $\mathrm{C}=91.0$ (s.e. 8.21 ) } \\
\hline \multicolumn{9}{|c|}{ Relative values } \\
\hline Source ${ }^{a)}$ & DF & SS & MS & Var.cp & s(V.cp) & $\mathrm{F}^{\mathrm{b})}$ & s.e. & LSD5 \\
\hline $\mathrm{Y}$ & 2 & 1340 & 670 & -3 & 16 & 0.84 & 4.7 & 15.03 \\
\hline $\mathrm{R}: \mathrm{Y}$ & 9 & 7155 & 795 & 49 & 40 & $2.25^{+}$ & 6.27 & 18.62 \\
\hline C & 2 & 4829 & 2415 & 43 & 49 & $2.74^{x}$ & 4.95 & 19.42 \\
\hline $\mathrm{CY}$ & 4 & 3522 & 881 & 44 & 43 & $2.49^{+}$ & 5.43 & 16.13 \\
\hline $\mathrm{RC}: \mathrm{Y}$ & 18 & 6363 & 353 & 50 & 40 & $1.74^{+}$ & 8.23 & 23.38 \\
\hline $\mathrm{S}$ & 2 & 432 & 216 & 6 & 4 & $12.81^{*}$ & 0.68 & 2.69 \\
\hline SY & 4 & 68 & 17 & -16 & 3 & 0.08 & 4.12 & 11.69 \\
\hline SC & 4 & 708 & 177 & -20 & 18 & 0.43 & 5.88 & 19.19 \\
\hline SCY & 8 & 3325 & 416 & 53 & 48 & $2.04^{+}$ & 7.13 & 20.25 \\
\hline \multirow[t]{2}{*}{ RSC:Y } & 50 & 10161 & 203 & 203 & 40 & & & \\
\hline & & & & & \multicolumn{4}{|c|}{ Heritability for $\mathrm{C}=63.5$ (s.e. 33.29 ) } \\
\hline a) Source o & iatior & R=Replica & Itivar, $\mathrm{S}=$ & n proven & & & & \\
\hline b) F-values & & vels: **,* & -values $=$ & $.05,0.1,0$ & spectively & & & \\
\hline
\end{tabular}

The analysis of additive main effects and multiplicative interaction (AMMI) shows strong variation for agronomic traits between years (FIGURE 5.2). In the dry treatment, season 2014 and 2015 are clustered separately from season 2016 according to the first principal component (PC1). In the irrigated treatment, season 2015 clusters separately from 2014 and 2016 for seed and total yield. Interaction of cultivars are going in opposite directions in all four traits for SL and GL, whereas PP shows smaller interactions. 
Significant differences between sub-populations within a cultivar could not be observed. Ranking of the sub-populations are not consistent across traits, but SL_R can always be found at the highest positive PC1 value (except for the harvest index), as well as PP_R compared to both other selections.
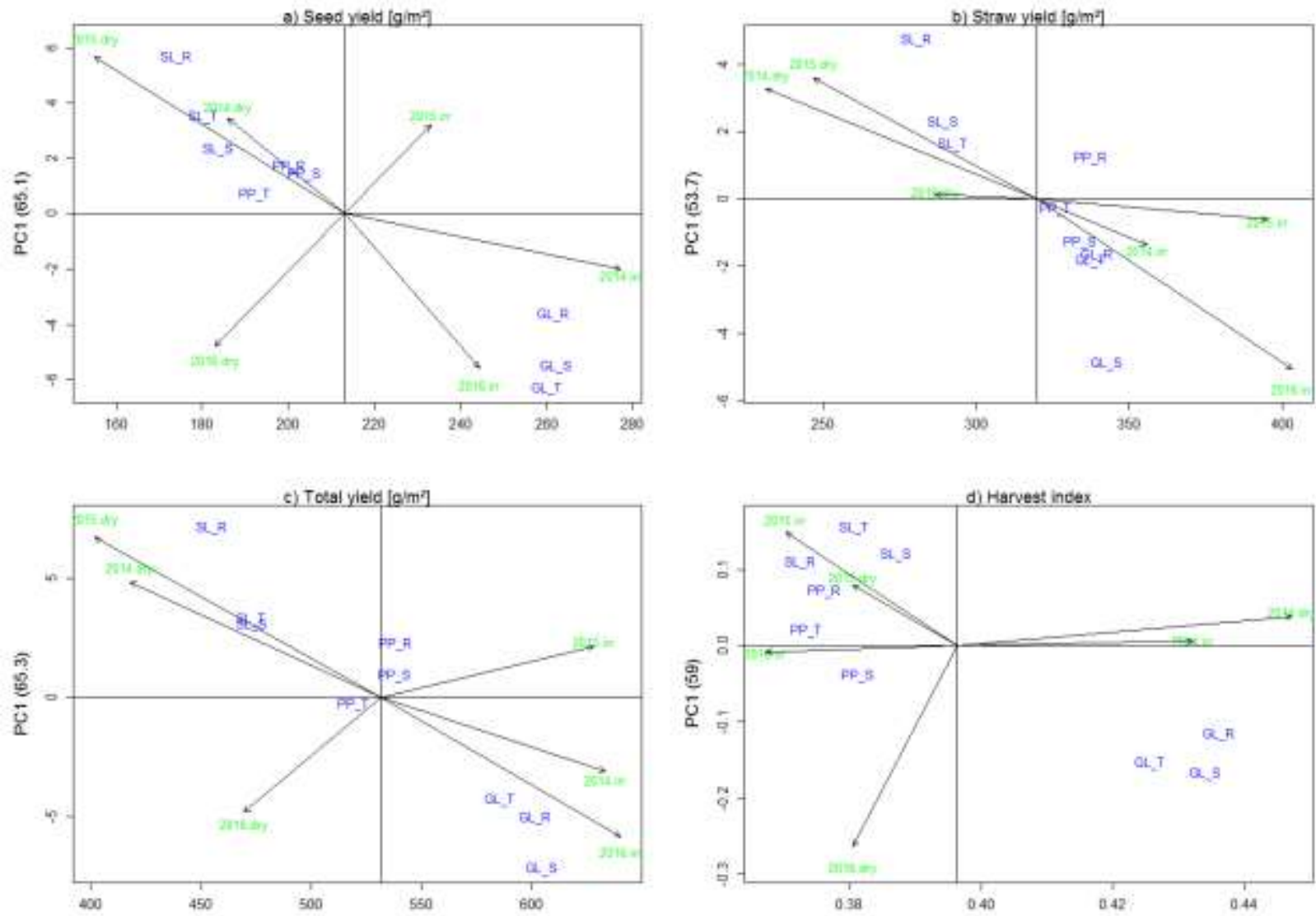

FIGURE 5.2 AMMI1 biplots for agronomic traits for six environments (three years $\times$ two treatments) for nine populations selected from three cultivars ( $P P, S L, G L)$ at three locations $(R, S, T)$. 


\section{PHENOLOGICAL AND MORPHOLOGICAL TRAITS}

Phenological traits were less affected by the treatments compared to yield and yield related traits. TABLE 5.9 shows mean values of the treatments for each cultivar and the relative values in the dry compared to the irrigated treatment for selected phenological traits; the F-values and significance levels are given for the treatment effect within cultivar and for the effect of cultivar on relative values. Leaf size was about 1$2 \mathrm{~cm}^{2}$ larger when irrigated and flowering time and ripening was earlier (higher scoring values) when dry. Survival rate shows only minor variation between treatments and was found slightly lower in the dry treatment for Pisarecka Perla.

TABLE 5.9 Mean and relative values of phenological traits of three cultivars ( 3 years).

\begin{tabular}{|c|c|c|c|c|c|c|c|c|c|c|c|c|c|c|c|}
\hline \multirow{2}{*}{$\begin{array}{l}\text { Cultivar } \\
\text { Treatment } \\
\text { Trait }^{\text {a) }}\end{array}$} & \multicolumn{4}{|c|}{ Pisarecka Perla } & \multicolumn{4}{|c|}{ Schwarze Linse } & \multicolumn{4}{|c|}{ Gestreifte Linse } & \multirow[b]{2}{*}{$F^{d)}$} & \multicolumn{2}{|c|}{ Mean } \\
\hline & irr. & dry & $\begin{array}{c}\text { rel. } \% \\
\text { b) }\end{array}$ & $\mathrm{Fc}^{\mathrm{c})}$ & irr. & dry & rel.\% & Fc) & irr. & dry & rel.\% & $\mathrm{F}^{\mathrm{c})}$ & & irr. & dry \\
\hline $\mathrm{LS}\left[\mathrm{cm}^{2}\right]$ & 13.9 & 11.7 & 85.57 & $3.47^{x}$ & 8.28 & 7.39 & 92.26 & 2.74 & 10.7 & 8.97 & 85.19 & $10.4^{+}$ & 1.07 & 10.96 & 9.35 \\
\hline $\mathrm{FT}^{\mathrm{e})}$ & 1.04 & 1.58 & na & 2.33 & 1.72 & 2.43 & na & $5.28^{x}$ & 0.33 & 1.30 & na & $3.80^{\mathrm{x}}$ & na & 1.03 & 1.77 \\
\hline Ripening & 4.38 & 7.40 & 168.5 & na & 5.15 & 8.38 & 162 & na & 3.75 & 7.82 & 259.8 & na & 1.20 & 4.43 & 7.87 \\
\hline SR [\%] & 97.4 & 96.3 & 98.88 & $5.08^{x}$ & 96.8 & 96.5 & 99.90 & 0.83 & 95.4 & 95.9 & 101.2 & 0.69 & 2.30 & 96.5 & 96.2 \\
\hline \multicolumn{16}{|c|}{ a) Leaf size = LS; flowering time = FT; survival rate $=\mathrm{SR}$} \\
\hline \multicolumn{16}{|c|}{$\begin{array}{l}\text { c) F-values with significance levels for treatment in ANOVA in the F-test (DF-nom.=1, DF-denom. }=2 \text { ): } \\
* *,+,{ }^{x} \text { for P-values }=0.01,0.05,0.1,0.2 \text {, respectively }\end{array}$} \\
\hline \multicolumn{16}{|c|}{$\begin{array}{l}\text { d) F-values with significance levels for the effect of the cultivar on relative values [\%] (F-test in ANOVA with DF-nom.=2, DF-denom.=4): } \\
* *, *,+{ }^{x} \text { for P-values }=0.01,0.05,0.1,0.2 \text {, respectively } \\
\text { e) Dates differ between cultivars: } 2^{\text {nd }} \text { date of scoring for PP and SL and } 3^{\text {rd }} \text { date for GL }\end{array}$} \\
\hline
\end{tabular}


Analysis of variance on flowering time scoring is summarized in TABLE 5.11 and shows highly significant effects of the year and cultivar and their interaction for both treatments. In the irrigated treatment, the effect of cultivar is more pronounced compared to the dry treatment and the heritability considerably high.

TABLE 5.11 ANOVA results for flowering time in dry and irrigated treatment.

\begin{tabular}{|c|c|c|c|c|c|c|c|c|}
\hline \multicolumn{9}{|c|}{ Dry treatment } \\
\hline Source ${ }^{a)}$ & DF & SS & MS & Var.cp & $s(V . c p)$ & $\mathrm{F}^{\mathrm{b})}$ & s.e. & LSD5 \\
\hline $\mathrm{Y}$ & 2 & 57.98 & 28.99 & 0.79 & 0.57 & $\begin{array}{c}45.70^{*} \\
*\end{array}$ & 0.13 & 0.42 \\
\hline$R: Y$ & 9 & 5.71 & 0.63 & 0.05 & 0.03 & $2.86^{*}$ & 0.16 & 0.47 \\
\hline $\mathrm{C}$ & 2 & 98.79 & 49.39 & 1.31 & 0.97 & $\begin{array}{c}23.20 * \\
*\end{array}$ & 0.24 & 0.95 \\
\hline $\mathrm{CY}$ & 4 & 8.52 & 2.13 & 0.16 & 0.10 & $9.61^{* *}$ & 0.14 & 0.4 \\
\hline RC:Y & 18 & 3.99 & 0.22 & 0.05 & 0.02 & $3.19 * *$ & 0.15 & 0.43 \\
\hline$S$ & 2 & 1.60 & 0.80 & 0.02 & 0.02 & $3.98^{x}$ & 0.07 & 0.29 \\
\hline SY & 4 & 0.81 & 0.20 & 0.01 & 0.01 & $2.90 *$ & 0.08 & 0.22 \\
\hline SC & 4 & 1.85 & 0.46 & 0.03 & 0.02 & $3.01^{+}$ & 0.11 & 0.37 \\
\hline SCY & 8 & 1.23 & 0.15 & 0.02 & 0.02 & $2.22 *$ & 0.13 & 0.37 \\
\hline RSC:Y & 52 & 3.54 & 0.07 & 0.07 & 0.01 & & 0.13 & 0.42 \\
\hline \multicolumn{9}{|c|}{ Heritability for $\mathrm{C}=95.7$ (s.e. 3.93) } \\
\hline \multicolumn{9}{|c|}{ Irrigated treatment } \\
\hline Source ${ }^{a)}$ & DF & SS & MS & Var.cp & $s(V . c p)$ & $\mathrm{F}^{\mathrm{b})}$ & s.e. & LSD5 \\
\hline $\mathrm{Y}$ & 2 & 12.18 & 6.09 & 0.15 & 0.12 & $9.98^{* *}$ & 0.13 & 0.42 \\
\hline$R: Y$ & 9 & 5.49 & 0.61 & 0.05 & 0.03 & $4.50^{* *}$ & 0.12 & 0.36 \\
\hline $\mathrm{C}$ & 2 & 146.54 & 73.27 & 2.00 & 1.44 & $\begin{array}{c}52.63^{*} \\
*\end{array}$ & 0.2 & 0.77 \\
\hline $\mathrm{CY}$ & 4 & 5.57 & 1.39 & 0.10 & 0.07 & $\begin{array}{c}10.25^{*} \\
*\end{array}$ & 0.11 & 0.32 \\
\hline RC:Y & 18 & 2.44 & 0.14 & 0.01 & 0.02 & 1.13 & 0.2 & 0.57 \\
\hline S & 2 & 1.39 & 0.69 & 0.01 & 0.01 & $3.84^{x}$ & 0.07 & 0.28 \\
\hline SY & 4 & 0.72 & 0.18 & 0.01 & 0.01 & 1.5 & 0.1 & 0.28 \\
\hline SC & 4 & 4.90 & 1.23 & 0.09 & 0.06 & $\begin{array}{c}13.33^{*} \\
*\end{array}$ & 0.09 & 0.29 \\
\hline $\mathrm{SCY}$ & 8 & 0.74 & 0.09 & -0.01 & 0.01 & 0.76 & 0.17 & 0.49 \\
\hline RSC:Y & 51 & 6.25 & 0.12 & 0.12 & 0.02 & & & \\
\hline \multicolumn{9}{|c|}{ Heritability for $\mathrm{C}=98.1$ (s.e. 1.73 ) } \\
\hline
\end{tabular}


Flowering was earlier in the dry treatment for all cultivars (FIGURE 5.3). Due to the strongly non-linear scoring scale, slopes cannot be compared in FIGURE 5.3. Nevertheless, we see the largest differences between treatments in Gestreifte Linse compared to Schwarze Linse and Pisarecka Perla. Furthermore, populations in Pisarecka Perls show more variation between each other than populations in Schwarze Linse and Gestreifte Linse. In Pisarecka Perla, the selection from Tangsehl was earlier flowering than the other selections, regardless of which treatment, while Tangsehl selections in Schwarze Linse and Gestreifte Linse were flowering later compared to the other selections and were showing a higher response to the dry treatment compared Pisarecka Perla.

$\mathrm{PP}$

4

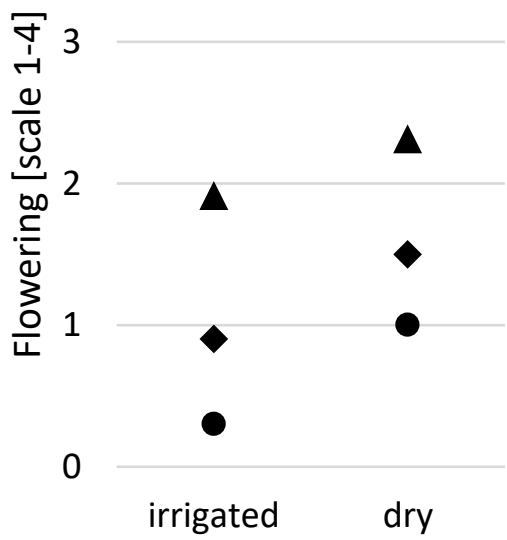

$S L$

4

3
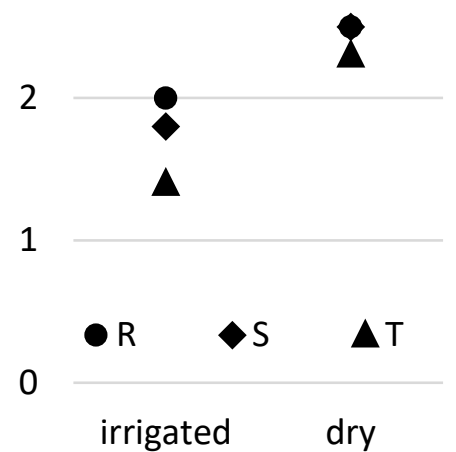

GL

4

3

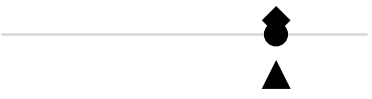

2

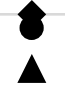

1

0

irrigated dry

Figure 5.3 Flowering time under irrigated and dry conditions of Pisarecka Perla (PP), Schwarze Linse (SL), and Gestreifte Linse (GL) populations selected at Reinshof (R), Schönhagen (S), and Tangsehl (T). Dates of scoring differ between cultivars: $2^{\text {nd }}$ date for PP and SL, $4^{\text {th }}$ date for GL (higher values = earlier flowering) 


\section{CANOPY TEMPERATURE AND ISOTOPE DATA}

TABLE 5.12 shows canopy temperature mean values for each cultivar and treatment and relative values at every individual date of measurement, the significance of treatment and cultivar effects and of the relative differences. Significant treatment effects were present in early June in 2015 at relatively high temperature. In 2014 for the first date on the $10^{\text {th }}$ of June significant treatment effects were not yet measured. For all remaining dates a strong influence of the treatment could be observed. Overall, relative canopy temperature increase was higher by $2 \%$ for Gestreifte Linse compared to Schwarze Linse and Pisarecka Perla. Most significantly, this was true for the $28^{\text {th }}$ of June 2016 , when Gestreifte Linse reached $28.4^{\circ} \mathrm{C}$ under drought stress compared to $24^{\circ} \mathrm{C}$ in the irrigated treatment and in this way experienced a relative temperature increase which is about $6 \%$ higher compared to Pisarecka Perla. In 2015, significant effects by cultivar were not observed.

TABLE 5.12 Mean and relative values of canopy temperature of the cultivars.

\begin{tabular}{|c|c|c|c|c|c|c|c|c|c|c|c|c|c|c|c|}
\hline \multirow[b]{3}{*}{ Year } & \multirow[b]{3}{*}{ Date } & \multicolumn{6}{|c|}{ Treatment } & \multirow{2}{*}{\multicolumn{2}{|c|}{ Mean }} & \multirow{2}{*}{\multicolumn{3}{|c|}{ relative $\%^{a)}$}} & \multirow{2}{*}{\multicolumn{3}{|c|}{ F-value ${ }^{\text {b) }}$}} \\
\hline & & \multicolumn{3}{|c|}{ irrigated } & \multicolumn{3}{|c|}{ dry } & & & & & & & & \\
\hline & & $\mathrm{PP}$ & $\mathrm{SL}$ & $\mathrm{GL}$ & PP & SL & $\mathrm{GL}$ & irr. & dry & $\mathrm{PP}$ & $\mathrm{SL}$ & $\mathrm{GL}$ & Treatm. & Cult. & C.r.\% \\
\hline \multirow[t]{4}{*}{2014} & $10^{\text {th }}$ June & 26.6 & 26.4 & 25.6 & 27.8 & 27.2 & 27.0 & 26.2 & 27.3 & 105 & 103 & 105 & 1.62 & $4.11 *$ & 0.63 \\
\hline & $27^{\text {th }}$ June & 20.2 & 20.1 & 19.6 & 21.7 & 21.6 & 21.6 & 20.0 & 21.6 & 107 & 108 & 110 & $55.28^{* *}$ & 1.25 & 0.05 \\
\hline & $4^{\text {th }}$ July & 27.7 & 27.3 & 26.9 & 32.9 & 31.8 & 31.5 & 27.3 & 31.1 & 119 & 117 & 118 & $117.36^{* *}$ & $3.26^{+}$ & 0.10 \\
\hline & $11^{\text {th }}$ July & 29.1 & 28.6 & 29.3 & 32.8 & 31.1 & 32.9 & 29.0 & 32.2 & 113 & 109 & 113 & $183.26 * *$ & $3.21^{+}$ & 0.65 \\
\hline \multicolumn{2}{|c|}{ Annual mean } & 25.9 & 25.6 & 25.4 & 28.8 & 27.9 & 28.3 & 25.6 & 28.3 & 111 & 109 & 112 & & & \\
\hline \multirow[t]{3}{*}{2015} & $5^{\text {th }}$ June & 27.3 & 27.4 & 26.5 & 30.7 & 30.0 & 30.3 & 27.1 & 30.3 & 113 & 109 & 114 & $37.17^{* *}$ & 1.44 & 1.30 \\
\hline & $12^{\text {th }}$ June & 27.0 & 27.1 & 27.7 & 31.0 & 31.0 & 30.8 & 27.3 & 30.9 & 115 & 114 & 111 & $60.67^{* *}$ & 0.14 & 0.30 \\
\hline & $2^{\text {nd }}$ July & 33.6 & 33.4 & 33.8 & 38.0 & 38.3 & 38.3 & 33.6 & 38.2 & 113 & 115 & 113 & $32.56 * *$ & 0.39 & 0.34 \\
\hline \multicolumn{2}{|c|}{ Annual mean } & 29.3 & 29.3 & 29.3 & 33.2 & 33.1 & 33.1 & 29.3 & 33.1 & 114 & 113 & 113 & & & \\
\hline \multirow[t]{3}{*}{2016} & $23^{\text {rd }}$ June & 29.4 & 29.2 & 28.9 & 33.3 & 33.4 & 33.2 & 29.2 & 33.3 & 113 & 114 & 115 & $470.92 * *$ & $3.74^{+}$ & 1.32 \\
\hline & $28^{\text {th }}$ June & 24.8 & 25.0 & 24.0 & 27.8 & 29.3 & 28.4 & 24.6 & 28.5 & 112 & 117 & 118 & $188.50 * *$ & $6.09 *$ & $4.19^{+}$ \\
\hline & $7^{\text {th }}$ July & 23.7 & 24.0 & 22.9 & 29.3 & 29.1 & 29.4 & 23.5 & 29.3 & 124 & 121 & 128 & $60.54^{* *}$ & 0.84 & 1.96 \\
\hline \multicolumn{2}{|c|}{ Annual mean } & 26.0 & 26.1 & 25.3 & 30.1 & 30.6 & 30.3 & 25.8 & 30.3 & 116 & 117 & 120 & & & \\
\hline \multicolumn{2}{|c|}{ Mean of 3 years } & 26.9 & 26.9 & 26.5 & 30.5 & 30.3 & 30.3 & 26.8 & 30.4 & 113 & 113 & 115 & & & \\
\hline \multicolumn{16}{|c|}{$\begin{array}{l}\text { b) F-values with significance levels of treatment, cultivar, and cultivar in relative data in ANOVA in the F-test } \\
\text { (treatment DF-nom. }=1 \text {, DF-denom. }=3 \text {; cultivar DF-nom.=2, DF-denom. }=12 \text {; cultivar rel.\% DF-nom.=2, DF-denom.=6): } \\
* *,+,+, \text { x for P-values }=0.01,0.05,0.1,0.2, \text { respectively }\end{array}$} \\
\hline
\end{tabular}

Significant effects of the selection provenances were observed on $4^{\text {th }}$ of July 2014 in all cultivars with larger relative values for selections from Schönhagen and Tangsehl in Pisarecka Perla and Gestreifte Linse, while in Schwarze Linse selection from Tangsehl had the lowest value (TABLE 5.13). The same trend towards higher relative temperature for selection from Tangsehl can be observed at most remaining dates and the overall mean in Pisarecka Perla. In cultivar Schwarze Linse and Gestreifte Linse, dates of measurement are indifferent resulting in overall means slightly higher for Schönhagen and Tangsehl in Schwarze Linse. Selections in Gestreifte Linse are not differing for the overall mean. 
TABLE 5.13 Mean and relative values of canopy temperature of the selection provenances $(R, S, T)$.

\begin{tabular}{|c|c|c|c|c|c|c|c|c|c|c|c|c|c|c|c|c|c|}
\hline \multirow[b]{3}{*}{ Year } & \multirow[b]{3}{*}{ Selection } & & \multirow[b]{3}{*}{ Fb) } & \multirow{2}{*}{\multicolumn{3}{|c|}{ Mean }} \\
\hline & & \multicolumn{12}{|c|}{ Schwarze Lins } & & & & \\
\hline & & $\mathrm{R}$ & $\mathrm{S}$ & $T$ & $\mathrm{~F}^{\mathrm{a})}$ & \multicolumn{2}{|c|}{$\begin{array}{ll} & \mathrm{Scn} W \\
\mathrm{R} \quad \mathrm{S}\end{array}$} & $T$ & $\mathrm{~F}^{\mathrm{a})}$ & $\mathrm{R}$ & $S$ & $T$ & Fa) & & $\mathrm{R}$ & $\mathrm{S}$ & $\mathrm{T}$ \\
\hline & & & & & & & & treat & nent & & & & & & & & \\
\hline 2014 & $10^{\text {th }}$ June & 26.8 & 26.9 & 26.8 & 0.14 & 27.2 & 27.2 & 27.3 & 0.06 & 27.0 & 26.7 & 27.4 & $4.63^{+}$ & 1.55 & 27.0 & 26.9 & 27.2 \\
\hline & $27^{\text {th }}$ June & 21.9 & 21.6 & 21.9 & 1.28 & 21.8 & 21.5 & 21.4 & 0.9 & 21.3 & 21.6 & 21.8 & $2.26^{x}$ & 0.67 & 21.7 & 21.6 & 21.7 \\
\hline & $4^{\text {th }}$ July & 32.2 & 32.5 & 32.0 & 0.39 & 31.9 & 32.0 & 31.4 & 1.61 & 31.3 & 31.7 & 31.6 & 1.37 & 1.51 & 31.8 & 32.1 & 31.7 \\
\hline & $11^{\text {th }}$ July & 31.7 & 32.1 & 31.6 & 0.26 & 30.9 & 31.1 & 31.4 & 0.37 & 33.1 & 33.0 & 32.7 & 1.6 & 0.23 & 31.9 & 32.1 & 31.9 \\
\hline & nual mean & 28.1 & 28.3 & 28.1 & & 28.0 & 27.9 & 27.9 & & 28.2 & 28.3 & 28.4 & & & 28.1 & 28.2 & 28.1 \\
\hline 2015 & $5^{\text {th }}$ June & 30.9 & 30.7 & 30.5 & 1.74 & 30.2 & 29.8 & 30.1 & 0.83 & 30.2 & 30.5 & 30.1 & 0.59 & 0.40 & 30.4 & 30.3 & 30.2 \\
\hline & $12^{\text {th }}$ June & 30.7 & 30.9 & 31.4 & 1.47 & 30.9 & 31.0 & 31.1 & 0.48 & 30.8 & 31.1 & 30.5 & 0.41 & 0.53 & 30.8 & 31.0 & 31.0 \\
\hline & $2^{\text {nd }}$ July & 38.1 & 37.8 & 38.1 & 0.72 & 38.4 & 38.2 & 38.3 & 0.28 & 38.1 & 38.6 & 38.3 & $10.27 *$ & 0.02 & 38.3 & 38.2 & 38.2 \\
\hline & nual mean & 33.2 & 33.1 & 33.3 & & 33.2 & 33.0 & 33.2 & & 33.0 & 33.4 & 33.0 & & & 33.1 & 33.2 & 33.2 \\
\hline 2016 & $23^{\text {rd }}$ June & 33.4 & 33.3 & 33.3 & 0.37 & 33.5 & 33.4 & 33.5 & 0.04 & 33.3 & 33.2 & 33.2 & 0.05 & 0.14 & 33.4 & 33.3 & 33.3 \\
\hline & $28^{\text {th }}$ June & 28.1 & 27.7 & 27.7 & 0.48 & 28.9 & 29.3 & 29.7 & 0.83 & 28.2 & 27.8 & 27.3 & 0.3 & 0.41 & 28.4 & 28.3 & 28.2 \\
\hline & $7^{\text {th }}$ July & 29.5 & 29.0 & 29.5 & 0.44 & 29.1 & 29.0 & 29.2 & 0.05 & 29.1 & 29.5 & 29.6 & 0.52 & 0.36 & 29.2 & 29.2 & 29.4 \\
\hline & nual mean & 30.3 & 30.0 & 30.2 & & 30.5 & 30.6 & 30.8 & & 30.2 & 30.2 & 30.0 & & & 30.3 & 30.3 & 30.3 \\
\hline Mear & of 3 years & 30.3 & 30.2 & 30.3 & & 30.3 & 30.2 & 30.3 & & 30.2 & 30.4 & 30.2 & & & 30.3 & 30.3 & 30.3 \\
\hline & & & & & & & Irriga & ed tre & atment & & & & & & & & \\
\hline 2014 & $10^{\text {th }}$ June & 26.6 & 26.4 & 26.6 & 0.60 & 26.3 & 26.5 & 26.3 & 0.42 & 25.5 & 25.7 & 25.7 & 0.39 & 0.15 & 26.1 & 26.2 & 26.2 \\
\hline & $27^{\text {th }}$ June & 20.1 & 20.1 & 20.3 & 0.31 & 20.1 & 20.3 & 19.8 & 1.53 & 19.7 & 19.5 & 19.7 & 1.99 & 0.02 & 20.0 & 20.0 & 19.9 \\
\hline & $4^{\text {th }}$ July & 27.9 & 27.5 & 27.7 & 0.99 & 27.3 & 27.1 & 27.4 & 0.71 & 27.2 & 26.7 & 26.8 & $3.51^{+}$ & $2.77^{+}$ & 27.5 & 27.1 & 27.3 \\
\hline & $11^{\text {th }}$ July & 28.8 & 29.2 & 29.1 & $14.4^{* *}$ & 28.9 & 28.6 & 28.4 & 1.97 & 28.7 & 29.7 & 29.5 & 0.81 & 0.66 & 28.8 & 29.2 & 29.2 \\
\hline & nual mean & 25.9 & 25.8 & 25.9 & & 25.7 & 25.6 & 25.5 & & 25.3 & 25.4 & 25.4 & & & 25.6 & 25.6 & 25.6 \\
\hline 2015 & $5^{\text {th }}$ June & 27.4 & 27.4 & 26.9 & 1.10 & 27.6 & 27.3 & 27.4 & 0.45 & 26.7 & 26.5 & 26.4 & 0.49 & 1.64 & 27.2 & 27.1 & 26.9 \\
\hline & $12^{\text {th }}$ June & 27.0 & 26.9 & 27.1 & 0.33 & 27.5 & 27.5 & 26.4 & 2.43 & 27.6 & 27.8 & 27.8 & 0.29 & 0.90 & 27.4 & 27.4 & 27.1 \\
\hline & $2^{\text {nd }}$ July & 33.8 & 33.5 & 33.5 & 1.10 & 33.2 & 33.5 & 33.6 & $4.0+$ & 33.9 & 33.7 & 33.7 & 0.61 & 0.29 & 33.6 & 33.6 & 33.6 \\
\hline & nual mean & 29.4 & 29.3 & 29.2 & & 29.4 & 29.4 & 29.1 & & 29.4 & 29.3 & 29.3 & & & 29.4 & 29.3 & 29.2 \\
\hline 2016 & $23^{\text {rd }}$ June & 29.3 & 29.7 & 29.1 & $4.32^{+}$ & 29.4 & 29.0 & 29.4 & 1.02 & 28.8 & 28.9 & 28.9 & 1.00 & 0.43 & 29.2 & 29.2 & 29.1 \\
\hline & $28^{\text {th }}$ June & 25.0 & 25.0 & 24.6 & 0.35 & 25.1 & 24.8 & 25.1 & 0.27 & 24.0 & 24.4 & 23.7 & $6.08 *$ & 0.76 & 24.7 & 24.7 & 24.5 \\
\hline & $7^{\text {th }}$ July & 23.6 & 23.7 & 23.8 & 0.10 & 24.2 & 24.1 & 23.9 & 0.58 & 23.0 & 23.2 & 22.6 & 1.97 & 1.04 & 23.6 & 23.7 & 23.4 \\
\hline & nual mean & 26.0 & 26.1 & 25.8 & & 26.2 & 26.0 & 26.1 & & 25.2 & 25.5 & 25.1 & & & 25.8 & 25.9 & 25.7 \\
\hline Mear & of 3 years & 27.0 & 26.9 & 26.9 & & 26.9 & 26.9 & 26.8 & & 26.5 & 26.6 & 26.5 & & & 26.8 & 26.8 & 26.7 \\
\hline & & & & & & & Relat & ve valu & es [\%] & & & & & & & & \\
\hline 2014 & $10^{\text {th }}$ June & 102 & 102 & 107 & $2.32^{x}$ & 103 & 103 & 104 & 0.97 & 106 & 104 & 106 & 0.94 & $14.3^{* *}$ & 104 & 103 & 106 \\
\hline & $27^{\text {th }}$ June & 109 & 107 & 104 & 2.00 & 108 & 106 & 108 & 0.80 & 108 & 111 & 111 & 1.84 & 0.05 & 108 & 108 & 108 \\
\hline & $4^{\text {th }}$ July & 114 & 118 & 123 & $24^{* *}$ & 117 & 118 & 114 & $5.14^{+}$ & 115 & 119 & 118 & $14^{* *}$ & $19.3 * *$ & 115 & 118 & 118 \\
\hline & $11^{\text {th }}$ July & 111 & 110 & 117 & $7.5^{*}$ & 107 & 109 & 110 & 1.63 & 116 & 112 & 111 & 1.87 & $4.19 *$ & 111 & 110 & 113 \\
\hline & nual mean & 109 & 109 & 113 & & 109 & 109 & 109 & & 111 & 112 & 112 & & & 110 & 110 & 111 \\
\hline 2015 & $5^{\text {th }}$ June & 113 & 112 & 113 & 0.32 & 110 & 109 & 110 & 0.10 & 113 & 115 & 114 & 0.35 & 0.18 & 112 & 112 & 112 \\
\hline & $12^{\text {th }}$ June & 114 & 115 & 116 & 0.46 & 113 & 113 & 118 & $2.95^{x}$ & 113 & 112 & 110 & 1.46 & 0.79 & 113 & 113 & 115 \\
\hline & $2^{\text {nd }}$ July & 113 & 113 & 114 & 0.18 & 116 & 114 & 114 & $2.70^{x}$ & 113 & 115 & 114 & $4.15^{+}$ & 0.14 & 114 & 114 & 114 \\
\hline & nual mean & 113 & 113 & 114 & & 113 & 112 & 114 & & 113 & 114 & 113 & & & 113 & 113 & 114 \\
\hline 2016 & $23^{\text {rd }}$ June & 114 & 112 & 114 & $4.43^{+}$ & 114 & 115 & 114 & 0.38 & 116 & 115 & 115 & 0.86 & 0.43 & 115 & 114 & 114 \\
\hline & $28^{\text {th }}$ June & 113 & 112 & 113 & 0.14 & 115 & 118 & 118 & 0.93 & 119 & 115 & 121 & 1.97 & 0.90 & 116 & 115 & 117 \\
\hline & $7^{\text {th }}$ July & 125 & 122 & 124 & 0.41 & 120 & 121 & 122 & 0.25 & 126 & 127 & 131 & 2.02 & 1.25 & 124 & 123 & 126 \\
\hline & nual mean & 117 & 115 & 117 & & 116 & 118 & 118 & & 120 & 119 & 122 & & & 118 & 117 & 119 \\
\hline Mear & of 3 years & 113 & 112 & 115 & & 112 & 113 & 113 & & 115 & 115 & 115 & & & 113 & 113 & 114 \\
\hline Rela & $\begin{array}{l}\text { with signif } \\
\times \text { for } \mathrm{P} \text {-valu } \\
\text { values in th }\end{array}$ & ryt & s fo & ectic & cross & vars & $\begin{array}{l}\text { nOV } \\
\text { n-av } \\
\text { ANO }\end{array}$ & the & est & $\mathrm{m} .=$ & 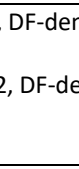 & & & & & & \\
\hline
\end{tabular}


Isotopic $\Delta{ }^{13} \mathrm{C}$ values are lower in the irrigated compared to the dry treatment for all cultivars for all types of samples. For seeds in 2015 differences between treatments are below the significance threshold (TABLE 5.14). Additionally, significant effects of the cultivar were observed in seeds in 2014 with lower values for Pisarecka Perla and Gestreifte Linse compared to Schwarze Linse and for straw in 2015 with Schwarze Linse and Gestreifte Linse exhibiting lower values compared to Pisarecka Perla in both treatments. Negative values result in relative values of $<100$, meaning an actual increase for the dry treatment (less negative values). For relative values, significant differences between cultivars at $P=0.05$ could not be found.

TABLE 5.14 Mean and relative values of $\Delta{ }^{13} \mathrm{C}$ for the cultivars Pisarecka Perla (PP), Schwarze Linse (SL), Gestreifte Linse (GL).

\begin{tabular}{|c|c|c|c|c|c|c|c|c|c|c|c|c|c|c|c|}
\hline & \multirow[b]{3}{*}{$\begin{array}{l}\text { Cultivar } \\
\text { Sample }\end{array}$} & \multicolumn{8}{|c|}{ Treatment } & & & & & & \\
\hline & & \multicolumn{3}{|c|}{ irrigated } & \multicolumn{3}{|c|}{ dry } & \multicolumn{2}{|c|}{ Mean } & \multicolumn{3}{|c|}{ rel.\%a) } & \multicolumn{3}{|c|}{ F-value ${ }^{b)}$} \\
\hline Year & & PP & $\mathrm{SL}$ & $\mathrm{GL}$ & PP & $\mathrm{SL}$ & GL & irr. & dry & $\mathrm{PP}$ & $\mathrm{SL}$ & $\mathrm{GL}$ & Trtm. & Cult. & $\begin{array}{l}\text { Cult. } \\
\text { rel.\% }\end{array}$ \\
\hline 2014 & Seed & -28.1 & -27.9 & -28.2 & -25.6 & -25.1 & -25.2 & -28.1 & -25.3 & 91 & 90 & 89 & $417.7^{* *}$ & 5.06* & $2.49^{x}$ \\
\hline \multirow[t]{4}{*}{2015} & Seed & -27.3 & -27.1 & -27.3 & -25.5 & -25.5 & -25.6 & -27.2 & -25.5 & 95 & 91 & 95 & 3.79 & 0.19 & 0.51 \\
\hline & Straw & -29.5 & -29.9 & -29.9 & -27.4 & -27.6 & -27.6 & -29.8 & -27.5 & 93 & 92 & 92 & $363.4^{* *}$ & $18.1^{* *}$ & 0.94 \\
\hline & Plant & -29.0 & -29.2 & -28.9 & -26.2 & -26.2 & -26.3 & -29.0 & -26.2 & 90 & 90 & 91 & $549.1 * *$ & 0.47 & $2.46^{x}$ \\
\hline & Mean & -28.5 & -28.5 & -28.6 & -26.2 & -26.1 & -26.2 & -28.5 & -26.2 & 92 & 91 & 92 & & & \\
\hline \multicolumn{16}{|c|}{ a) Relative values [\%] for cultivars in dry treatment compared to irrigated } \\
\hline \multicolumn{16}{|c|}{$\begin{array}{l}\text { b) F-values with significance levels of treatment, cultivar, and cultivar in relative data in ANOVA in the F-test } \\
\text { (treatment DF-nom. }=1 \text {, DF-denom. }=3 \text {; cultivar DF-nom.=2, DF-denom.=12; cultivar rel.\% DF-nom.=2, DF-denom.=6): } \\
* *, *,+, \text { x for P-values }=0.01,0.05,0.1,0.2, \text { respectively }\end{array}$} \\
\hline
\end{tabular}


Looking on specific selections within cultivars separately, isotopic data show small variation and in most cases no significant selection effects (TABLE 5.15).

TABLE 5.15 Mean and relative values of $\Delta{ }^{13} \mathrm{C}$ for the selection provenances Reinshof (R), Schönhagen (S), Tangsehl ( $\mathrm{T})$.

\begin{tabular}{|c|c|c|c|c|c|c|c|c|c|c|c|c|c|c|c|c|c|}
\hline \multirow[b]{3}{*}{ Year } & \multirow[b]{3}{*}{$\begin{array}{l}\text { Selection } \\
\text { Sample }\end{array}$} & \multicolumn{13}{|c|}{ Cultivar } & \multirow{2}{*}{\multicolumn{3}{|c|}{ Mean }} \\
\hline & & \multicolumn{4}{|c|}{ Pisarecka Perla } & \multicolumn{4}{|c|}{ Schwarze Linse } & \multicolumn{4}{|c|}{ Gestreifte Linse } & \multirow[b]{2}{*}{$\mathrm{Fb})$} & & & \\
\hline & & $\mathrm{R}$ & $S$ & $\mathrm{~T}$ & Fa) & $\mathrm{R}$ & $S$ & $\mathrm{~T}$ & Fa) & $R$ & $\mathrm{~S}$ & $\mathrm{~T}$ & Fa) & & $\mathrm{R}$ & $\mathrm{S}$ & $\mathrm{T}$ \\
\hline \multicolumn{18}{|c|}{ Dry treatment } \\
\hline 2014 & Seed & -25.6 & -25.6 & -25.7 & 0.31 & -25.2 & -25.1 & -25.0 & 0.18 & -25.2 & -25.1 & -25.2 & 0.44 & 0.34 & -25.3 & -25.3 & -25.3 \\
\hline \multirow[t]{4}{*}{2015} & Seed & -25.8 & -25.8 & -25.7 & $3.96^{+}$ & -25.1 & -25.0 & -25.2 & 1.75 & -25.5 & -25.7 & -25.6 & 1.1 & 0.23 & -25.5 & -25.5 & -25.5 \\
\hline & Straw & -27.3 & -27.6 & -27.3 & $3.34^{x}$ & -27.6 & -27.6 & -27.6 & 0.06 & -27.5 & -27.6 & -27.6 & 0.42 & $2.65^{+}$ & -27.5 & -27.6 & -27.5 \\
\hline & Plant & -26.2 & -26.3 & -26.1 & 0.62 & -26.1 & -26.3 & -26.2 & 0.38 & -26.1 & -26.3 & -26.3 & 0.42 & 0.91 & -26.1 & -26.3 & 26.2 \\
\hline & Mean & -26.2 & -26.3 & -26.2 & & -26.0 & -26.0 & -26.0 & & -26.1 & -26.2 & -26.2 & & & -26.1 & -26.2 & -26.1 \\
\hline \multicolumn{18}{|c|}{ Irrigated treatment } \\
\hline 2014 & Seed & -28.1 & -28.2 & -28.0 & 1.54 & -27.9 & -27.9 & -27.9 & 0.05 & -28.1 & -28.3 & -28.3 & $2.53^{x}$ & 1.22 & -28.1 & -28.1 & -28.1 \\
\hline \multirow[t]{4}{*}{2015} & Seed & -27.4 & -27.3 & -27.0 & $2.34^{x}$ & -27.6 & -27.4 & -27.4 & $2.79^{x}$ & -26.9 & -27.2 & -26.9 & $9.7^{*}$ & $5.24 *$ & -27.3 & -27.3 & -27.1 \\
\hline & Straw & -29.5 & -29.6 & -29.5 & 0.33 & -30.0 & -29.8 & -29.9 & 0.64 & -29.9 & -30.0 & -29.9 & $2.29^{\mathrm{x}}$ & 0.77 & -29.8 & -29.8 & -29.8 \\
\hline & Plant & -28.8 & -29.3 & -29.0 & 2.07 & -29.3 & -29.1 & -29.2 & 0.23 & -28.8 & -29.0 & -28.9 & 1.27 & 1.13 & -29.0 & -29.1 & -29.0 \\
\hline & Mean & -28.4 & -28.6 & -28.4 & & -28.7 & -28.5 & -28.6 & & -28.4 & -28.6 & -28.5 & & & -28.5 & -28.6 & -28.5 \\
\hline \multicolumn{18}{|c|}{ Relative [\%]c) } \\
\hline 2014 & Seed & 91 & 91 & 91 & 0.62 & 90 & 90 & 90 & 0.86 & 90 & 89 & 89 & $2.93^{x}$ & $2.59^{\mathrm{x}}$ & 90 & 90 & 90 \\
\hline \multirow[t]{4}{*}{2015} & Seed & 95 & 95 & 96 & 1.19 & 91 & 91 & 92 & $2.53 x$ & 95 & 95 & 95 & 1.30 & $3.93^{*}$ & 94 & 94 & 94 \\
\hline & Straw & 92 & 93 & 92 & na & 92 & 93 & 93 & 0.63 & 92 & 92 & 92 & 0.12 & 1.70 & 92 & 93 & 92 \\
\hline & Plant & 91 & 90 & 90 & 1.54 & 89 & 90 & 90 & 0.38 & 91 & 91 & 91 & 0.20 & 0.03 & 90 & 90 & 90 \\
\hline & Mean & 92.3 & 92.3 & 92.3 & & 90.5 & 91.0 & 91.3 & & 92.0 & 91.8 & 91.8 & & & 91.6 & 91.7 & 91.8 \\
\hline \multicolumn{18}{|c|}{$\begin{array}{l}\text { a) F-values with significance levels for selection in ANOVA in the F-test (DF-nom.=2, DF-denom. }=6 \text { ): } \\
* *, *,+\times \text { for P-values }=\text { to } 0.01,0.05,0.1,0.2, \text { respectively; na for not available results data }\end{array}$} \\
\hline \multicolumn{18}{|c|}{$\begin{array}{l}\text { b) F-values with significance levels for selection across cultivars in ANOVA in the F-test (DF-nom.=2, DF-denom. }=6 \text { ): } \\
* *, *{ }^{*}{ }^{\times} \text {for P-values }=0.01,0.05,0.1,0.2 \text {, respectively; na = non-available data }\end{array}$} \\
\hline c) $\mathrm{Rel}$ & tive values in & the dry & treatme & nt comp & ared to & irigate & & & & & & & & & & & \\
\hline
\end{tabular}




\subsection{DISCUSSION}

The experiment could technically only be realized at Reinshof, where the soil is fertile and loamy with a good water holding capacity. Since field plots were sown by machine, rainout shelters could only be installed after sowing and the soil received precipitation until it was covered latest around three weeks after sowing; for one shelter in 2014 weather conditions and technical issues delayed covering until four weeks after sowing (TABLE 5.4). Consequently, dry conditions for the plants developed gradually after field plots were sheltered. During germination and field emergence, contrasting conditions between the treatments were not yet established, thus, significant differences for field emergence and survival could not be observed. Under the given circumstances, the initial goal of the drought stress experiment, to realize strong yield depression of $50 \%$ or more compared to the irrigated treatment, could not be achieved. However, a significant yield depression of $27-36 \%$, depending on the cultivar, in the average of the three seasons was reached.

Yield potential differs between cultivars and beside the significant interaction of cultivar and year (TABLE 5.8), a smaller cultivar $x$ treatment interaction was also observed for straw and total yield (data not shown). The highest yielding cultivar Gestreifte Linse suffered from strongest yield depression for straw and total yield, medium yielding Pisarecka Perla experienced the least depression in yield (TABLE 5.6). It can be assumed according to the strong differences in morphological traits (e.g. growth type) between the cultivars, that root traits may also differ between our cultivars. In general, the root system of lentil is described by Saxena (2009) as "a slender taproot system with a mass of fibrous lateral roots". Variation between genotypes for multiple root traits were reported by Sarker et al. (2005), including the length of the taproot and the number of lateral roots, and they linked drought tolerance of a breeding line mainly to the number of lateral roots and fast root growth. In another study, high association between root and shoot traits was found in well-watered and dry treatments (Idrissi et al. 2015).

Visible differences between treatments were present earliest at the stage of full flowering mid of June, approximately five weeks after field plots were covered by the rainout shelters, by a lighter green color of the irrigated plots compared to a darker green color in dry plots (FIGURE 5.4). However, flowering could be observed slightly earlier in the dry plots for all cultivars, indicating that desiccation was influencing the plants already before flowering. Leaf samples for the leaf size scan were taken after flowering during grain filling stage. Leaf size was larger under irrigated conditions, which was significant in Pisarecka Perla and Gestreifte Linse with $\mathrm{P}=0.2$ and $\mathrm{P}=0.1$, respectively. This correlates with the results for seed weight, being higher as well in all cultivars when irrigated and significantly different for Pisarecka Perla and Gestreifte Linse with $P=0.2$ and $P=0.05$, respectively.

Significant differences between treatments in canopy temperature could be measured earliest in early June 2015. In 2014, differences between treatments were observed at the end of June, which may be due to later covering and the heavy rainfall event on $12^{\text {th }}$ of June 2014. Cultivar specific differences in canopy temperature were observed end of June until beginning of July in 2014 and 2016, but for none of the measurement dates in 2015. Thermal infrared measurements are strongly dependent on air temperature, air humidity, solar altitude, and shading. As Jones et al. (2009) documented, also the canopy structure affects the observed temperature and may explain the differences observed between our three cultivars, where a higher temperature with up to $1^{\circ} \mathrm{C}$ was measured in the more erect growing cultivars Pisarecka Perla and Schwarze Linse, compared to Gestreifte Linse, under irrigated conditions. Under dry conditions, this effect was less pronounced and could only be observed during two dates in 2014, which may be explained with a less copious, overhanging growth of Gestreifte Linse and consequently a less distinct 
canopy structure between the cultivars in the dry plots. Thus, Gestreifte Linse had the highest overall mean in the relative temperature.

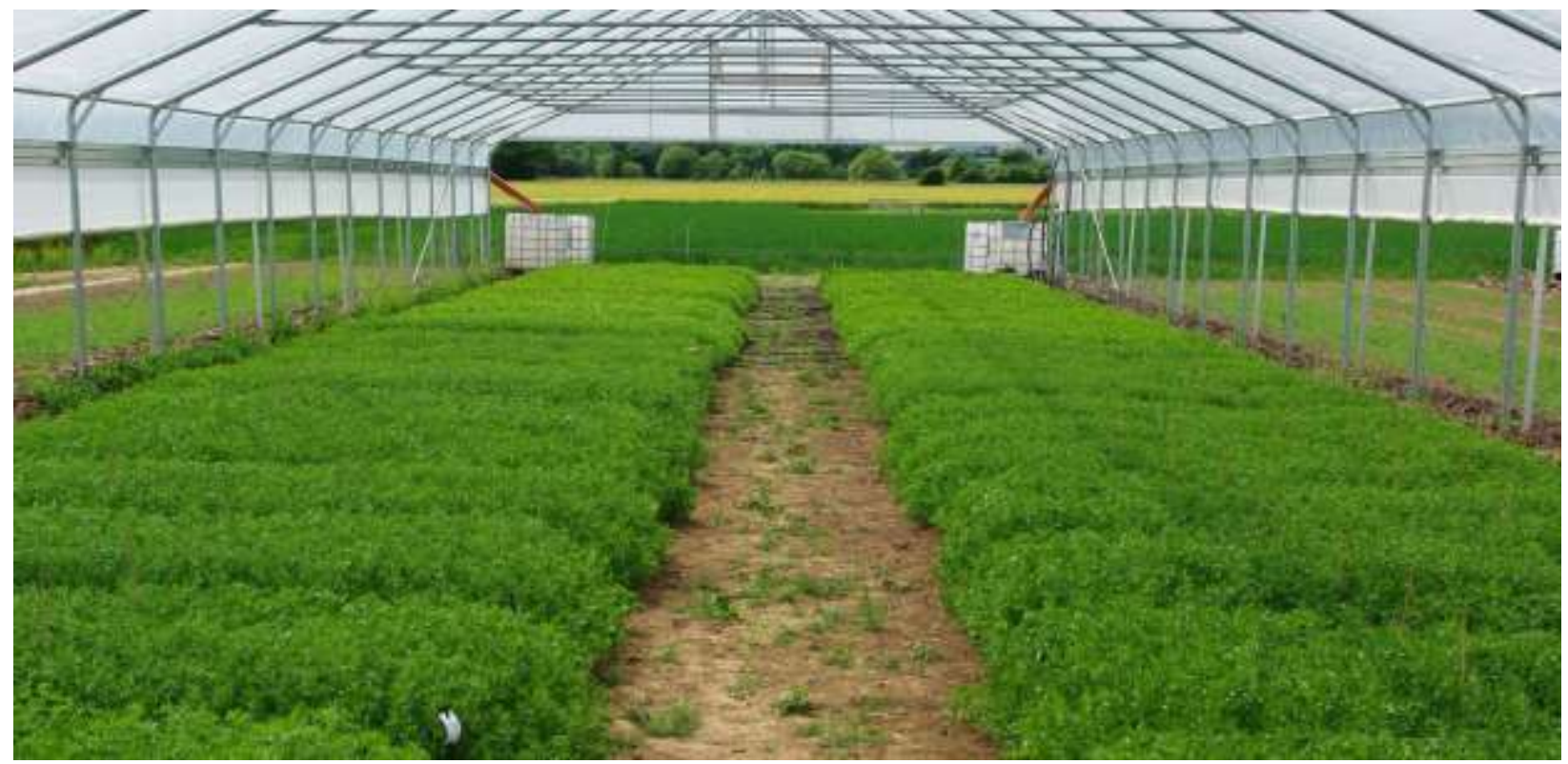

FIGURE 5.4 Lentil drought stress experiment under the rainout shelter on $17^{\text {th }}$ of June 2015

Isotopic carbon fractioning gave inconsistent results, showing significant differences between treatments and cultivars in 2014 for seed samples, whereas in 2015 treatments could be significantly distinguished for straw and midterm plant samples, but not for seed samples due to a highly significant replication $x$ treatment interaction. However, the absolute mean values are consistently higher in the dry treatment for all cultivars and all types of samples, supporting the general hypothesis of a reduced transpiration rate leading to reduced isotope discrimination and a higher $\Delta^{13} \mathrm{C}$ value under drought conditions. Cultivar Schwarze Linse had the highest absolute value from seed samples in 2014 in both treatments, suggesting a lower transpiration rate in this cultivar, which would correspond to its smallest leaf size and lowest yield potential, compared to the other cultivars.

The effect of the selection provenance on the performance under drought stress was significant in Pisarecka Perla for seed and in Gestreifte Linse for straw yield with the highest yield under drought stress for the selection from Reinshof. Across cultivars, seed yield and total yield were highest for Reinshof selections, which was significant at $\mathrm{P}=0.1$ for the latter trait. Phenological and morphological traits exhibited a larger and significant within-cultivar variation in the dry treatment, e.g. leaf size in Schwarze Linse, flowering and ripening in Gestreifte Linse. Kumar et al. (2012) identified among others traits, early flowering and maturity, biological yield, and the harvest index as key traits for the selection under dry conditions for drought tolerance in an environment where terminal drought is limiting yield.

Canopy temperature can be a useful tool, also under field conditions, for selection under drought and heat stress, according to Mason and Singh (2014). In our experiment, it was an easy method to observe border effects and to monitor the irrigated as well as the dry field plots. However, potential small differences between genotypes may not be detected under field conditions due to many environmental factors influencing the measurement (Jones et al. 2009). Isotopic carbon fractioning could serve as well, as a valuable tool, especially when the interest lays in the examination of the physiological responses behind differences in drought tolerance (e.g. Chaves et al. 2003). To examine differences between stress 
conditions of the three locations, I recommend to analyze seeds harvested at each location from several years and in this way proof if drought stress was a significant factor differentiating Tangsehl from the two other locations. However, for large breeding trials this method might be rather expensive and laborious and certainly could not differentiate the expected small differences between our lentil populations.

In conclusion, natural selection on-farm for ten generations did not lead to a significant differentiation in drought tolerance. The 'richest' location (Reinshof) seemed to have returned the best drought tolerant populations according to seed yield. Environmental (pedoclimatic) conditions at Tangsehl were expected to trigger natural selection towards adaptation to drought stress conditions. However, this could not be observed in our experiment. Possible explanations could be i) drought stress was not a significant factor differentiating the selection sites, ii) genetic diversity in the initial material was not sufficient, iii) drought conditions induced at Reinshof were not large enough, iv) other parameters, e.g. seed size in Pisarecka Perla and Schwarze Linse, were of advantage for seed yield under induced drought stress at Reinshof, $v$ ) drought stress at Reinshof differed from drought stress in Tangsehl and Schönhagen, e.g. induced too late. 


\section{REFERENCES}

Aston AR, van Bavel C (1972) Soil surface water depletion and leaf temperature. Agronomy Journal(64):368-373

Blum A, Mayer J, Gozlan G (1982) Infrared thermal sensing of plant canopies as a screening technique for dehydration avoidance in wheat. Field Crops Research 5:137-146. doi: 10.1016/0378-4290(82)900144

Bockelmann M (2017, unpublished) Standortspezifische Populationsentwicklung durch natürliche Selektion am Beispiel der Linse, im zweijähringen Test: M. Sc. Thesis, Georg-August-Universität, Göttingen

Brueck H, Senbayram M (2009) Low nitrogen supply decreases water-use efficiency of oriental tobacco. J. Plant Nutr. Soil Sci. 172(2):216-223. doi: 10.1002/jpln.200800097

Chaves MM, Maroco JP, Pereira JS (2003) Understanding plant responses to drought - from genes to the whole plant. Functional Plant Biology 30(3):239-264. doi: 10.1071/FP02076

Ehrler WL, van Bavel C (1967) Sorghum foliar responses to changes in soil water content. Agronomy Journal 59(59):243-246

Erskine W, Muehlbauer FJ (1991) Allozyme and morphological variability, outcrossing rate and core collection formation in lentil germplasm. Theoretical and Applied Genetics 83(1):119-125. doi: 10.1007/BF00229234

Farquhar GD, Richards RA (1984) Isotopic Composition of Plant Carbon Correlates With Water-Use Efficiency of Wheat Genotypes. Australian Journal of Plant Physiology 11(6):539-552

Grant OM, Chaves MM, Jones HG (2006) Optimizing thermal imaging as a technique for detecting stomatal closure induced by drought stress under greenhouse conditions. Physiologia Plantarum(127):507-518

Horneburg B (2003) Standortspezifische Sortenentwicklung: Eine Studie mit Landsorten der Linse: Schriften zu Genetischen Ressourcen. Band 21

Horneburg B (2006) Outcrossing in lentil (Lens culinaris) depends on cultivar, location and year, and varies within cultivars. Plant Breeding 125(6):638-640

Horneburg B, Becker HC (2008) Crop Adaptation in On-Farm Management by Natural and Conscious Selection: A Case Study with Lentil. Crop Science 48(1):203-212

Idrissi O, Houasli C, Udupa SM, Keyser E de, van Damme P, Riek J de (2015) Genetic variability for root and shoot traits in a lentil (Lens culinaris Medik.) recombinant inbred line population and their association with drought tolerance. Euphytica 204(3):693-709. doi: 10.1007/s10681-015-1373-8

Idrissi O, Udupa SM, Keyser E de, McGee RJ, Coyne CJ, Saha GC, Muehlbauer FJ, van Damme P, Riek J de (2016) Identification of Quantitative Trait Loci Controlling Root and Shoot Traits Associated with Drought Tolerance in a Lentil (Lens culinaris Medik.) Recombinant Inbred Line Population. Front. Plant Sci. 7(1174):1-11. doi: 10.3389/fpls.2016.01174

Imam AG, Allard RW (1965) Population studies in predominantly self-pollinating species. VI. Genetic variability between and within natural populations of wild oats from differing habitats in california. Genetics 51(51):40-62 
Jones HG, Serraj R, Loveys BR, Xiong L, Wheaton A, Price AH (2009) Thermal infrared imaging of crop canopies for the remote diagnosis and quantification of plant responses to water stress in the field. Functional Plant Biology(36):978-989

Kumar J, Basu PS, Srivastava E, Chaturvedi SK, Nadarajan N, Kumar S (2012) Phenotyping of traits imparting drought tolerance in lentil. Crop \& Pasture Science 63:547-554

Mason RE, Singh RP (2014) Considerations when deploying canopy temperature to select high yielding wheat breeding lines under drought and heat stress. Agronomy(4):191-201

Materne M, Siddique K (2009) Agroecology and crop adaptation. In: Erskine W, Muehlbauer FJ, Sarker A, Sharma B (eds) The lentil: botany, production and uses. CAB International, Oxfordshire, pp 47-63

Mendiburu Fd (2016) R CRAN Package 'agricolae': Statistical Procedures for Agricultural Research

Patel N, Mehta A, Shekh A (2001) Canopy temperature and water stress quantificaiton in rainfed pigeonpea (Cajanus cajan (L.) Millsp.). Agricultural and Forest Meteorology 109(3):223-232. doi: 10.1016/S0168-1923(01)00260-X

Robinson D (2000) Using stable isotope natural abundances (delta15N and delta13C) to integrate the stress responses of wild barley (Hordeum spontaneum C. Koch.) genotypes. Journal of Experimental Botany 51(342):41-50. doi: 10.1093/jexbot/51.342.41

RStudio Team (2015) RStudio: Integrated Development for R: RStudio, Inc., Boston, MA URL http://www.rstudio.com/

Saha SK, Gopalan AA, Kamat DS (1986) Relations between remotely sensed canopy temperature, crop water stress, air vapour pressure deficit and evapotranspiration in chickpea. Agricultural and Forest Meteorology 38(1-3):17-26. doi: 10.1016/0168-1923(86)90047-X

Sarker A, Erskine W, Singh M (2005) Variation in shoot and root characteristics and their association with drought tolerance in lentil landraces. Genet Resour Crop Evol 52(1):89-97. doi: 10.1007/s10722-0050289-x

Saxena MC (2009) Plant morphology, anatomy and growth habit. In: Erskine W, Muehlbauer FJ, Sarker A, Sharma B (eds) The lentil: botany, production and uses. CAB International, Oxfordshire, pp 34-46

Senbayram M, Tränkner M, Dittert K, Brück H (2015) Daytime leaf water use efficiency does not explain the relationship between plant $\mathrm{N}$ status and biomass water-use efficiency of tobacco under nonlimiting water supply. J. Plant Nutr. Soil Sci. 178(4):682-692. doi: 10.1002/jpln.201400608

Silim SN, Saxena MC, Erskine W (1993) Adaptation of Lentil to the Mediterranean Environment. I. Factors Affecting Yield Under Drought Conditions. Experimental Agriculture 27:155-175

Utz HF (2011) PLABSTAT: Software for the statistical analysis of experiments in the area of plant breeding. Institut of Plant Breeding, Seed Science and Populations Genetics, Universität Hohenheim, Hohenheim

Wiegand CL, Namken LN (1966) Influence of plant moisture stress, solar radiatioin and air temperature on cotton leaf temperature. Agronomy Journal(58):582-586 


\section{GeNERAL DISCUSSION AND CONCLUSIONS}

Populations developed by natural selection on-farm did not show significant site-specific adaptation for yield (CHAPTER 2). Nevertheless, significant changes in seed weight and flowering time were observed for the cultivar Pisarecka Perla, caused by directional selection, as development of seed weight was continuous and may have led to adaptation to the most stress-prone environment. But this specific population (Pisarecka Perla selected at Tangsehl) benefited also in the other test locations from lower seed weight and earlier flowering under the environmental conditions during the test years. Different approaches for an explanation are possible: Effects of site-specific adaptation by natural selection in terms of yield i) may have been too small to detect in a two-year field performance test, and/or ii) ten generations may have been too short to result in significant yield advantages; or iii) the three selection sites have not been as distinctly different as expected and the effect of year during natural selection counteracted a continuous directional selection towards adaptation to site-specific conditions. The general tendency towards better yield across locations and cultivars in the tenth generation compared to generation five and the initial material may suggest for a combination of the first and second explanation. Since Pisarecka Perla shows significant site-specific development, the three selection sites are expected to have influenced natural selection differently, but a lower initial genetic variation within the other two cultivars may have hampered significant changes in this material for a limited number of generations.

From the assessment of phenotypic and genotypic variation within the initial material and within sitespecific populations from natural selection (CHAPTER 3), it became apparent that the cultivar Pisarecka Perla experienced significant changes by site-specific natural selection corresponding to genotypic variation especially in seed weight and flowering time within the initial population. The initial populations of Gestreifte Linse and Schwarze Linse did not show significant genotypic variability. Genetic variability and recombination observed within Pisarecka Perla enabled a dynamic development. The development differs significantly between selection sites proving on-farm management a dynamic approach for the maintenance of genetic resources. It was observed that the seed size was significantly altered by natural selection in both directions depending on the selection site, whereas for one population of Pisarecka Perla and all populations of the other cultivars it was constant or slightly increased.

Selection for seed size can help to improve yield and harvest index (CHAPTER 4). For Pisarecka Perla, the initial genetic variability was maintained by the selection on extreme seed size and additional variability was observed within the small seeded selection suggesting within-cultivar recombination. Strong selection for extreme seed size resulted unintentionally in a change of the original material by spontaneous outcrossing and/or recombination, as observed in the large seeded selection of Schwarze Linse and the small seeded selection of Gestreifte Linse.

A significantly smaller seed weight and earlier flowering for the population of Pisarecka Perla selected at the most 'stress-prone' location did not determine significant adaptation to drought stress when compared to the other populations in terms of yield (CHAPTER 5). Thus, drought stress may not have been the most important driving factor for natural selection at this location. In the populations of the other two cultivars, absence of variation for drought stress tolerance corresponds to a very low genetic variability among them. 
To study site-specific adaptation by natural selection and the underlying factors involved in a predominantly autogamous crop, I recommend using genetically broad populations, e.g. composite crosses or diverse lines, which should be phenotypically and genotypically characterized in advance. After several generations of natural selection at diverse locations, genotypic markers should be employed to study population structure and compare populations in different generations between the locations. Phenotypic assessments from field plots may help to identify specific sets of traits involved in adaptation to specific conditions.

On-farm management as a tool for the dynamic maintenance of plant genetic resources in autogamous crops may be considered for both, genetically diverse populations, but also genetically narrow cultivars or landraces. At least two diverse locations distinctly different in climatic and/or pedoclimatic and/or biotic and abiotic stress conditions are necessary to maintain diversity in accessions in on-farm management. Homogenous accessions could be maintained at one farm, but a backup stored at regular intervals to maintain the accessions in case of crop loss or seed-borne diseases is essential. I recommend using molecular markers to characterize the material of interest for its genetic diversity and subsequently decide on the maintenance strategy accordingly. Selection for seed size or for other traits, which are considered to be negative for the agronomic performance (e.g. plant height in cereals) or which are characteristic for the material, should be done regularly, depending on the outcrossing rate of the crop. For maintenance, on the other hand, selection bears the risk of selecting 'off-types' from spontaneous outcrossing and thus, the original population may be unintentionally changed. 'Phenotypic markers' like cotyledon color, hypocotyl color of seedlings or seed color should be monitored thoroughly to identify genetic recombination and outcrossing. I do not recommend managing different material at one farm, if the main purpose is the maintenance e.g. of a landrace, but a strict isolation, because the risk of outcrossing or admixture is high. Regular monitoring by molecular markers may allow the identification of unwanted genetic changes at an early stage and in such a case, backup samples are essential and the strategy or local system of the on-farm management should be reconsidered and revised.

From the perspective of farmers, for dynamic management using site-specific adaptation effects resulting in a locally adapted farm-race, I recommend using mixtures of accessions, e.g. of a genetically diverse landrace, from different locations within the distribution area to benefit from a larger gain of selection due to a higher genetic diversity within the starting material. 


\section{SUMMARY}

In the context of conservation and use of plant genetic resources, both storage in gene banks (ex situ) and safeguard on-farm (in situ) are important concepts. Increasingly attention focuses on the on-farm management of plant genetic resources as a dynamic maintenance strategy. To date, little is known about the potential of 'evolutionary' adaptation to site-specific conditions and the mechanisms involved. Lentil is an autogamous food legume crop with limited recombination. In long-term experiment three old lentil cultivars were exposed to ten generations of natural selection at three farms in Central and Northern Germany under rain-fed conditions. Two of the selection sites were on soils with low fertility and expected frequent shortages in water supply during the growing season. The following four main questions were investigated: i) Did natural selection during ten generations lead to site-specific adaptation in terms of yield? ii) Did natural selection alter phenotypic and genotypic variability? iii) What is the importance of seed weight for natural selection and adaptation? iv) Was drought a significant factor for site-specific development?

The three lentil cultivars are distinctly different in their morphological and phenological traits. Populations in the fifth and tenth generation under site-specific natural selection within each cultivar and the corresponding initial material were compared in a two-year field trial at the three selection sites. Singleplant progeny testing during two years at one location and SNP genotyping using KASPar ${ }^{\mathrm{TM}}$ assays was done to assess phenotypic and genotypic within-population variability. Selections for extreme seed size for six generations from each cultivar were phenotyped in the field and genotyped by SNP markers. Additionally, populations in the tenth generation of natural selection were tested in induced drought in rainout shelters for their variation in drought stress tolerance during three years at one location.

Significant continuous site-specific changes in seed weight and flowering time in both directions were observed for one cultivar. Natural selection at the more stress-prone location led to a lower seed weight and earlier flowering, whereas in the most fertile location selection favored larger seeded genotypes and later flowering. However, these changes did not lead to a significant site-specific adaptation in terms of yield. But a general yield advantage across locations for the population with a lower seed weight and earlier flowering was observed. A general tendency towards better yield for the latest generations across cultivars and locations suggests that natural selection was positive in terms of the general performance.

Phenotypic and genotypic variation within the initial material of one cultivar goes back to three main genotypes, which differ significantly in seed weight and flowering time. The observed phenotypic changes and site-specific differences in the genetic variability are supposedly caused by different selection pressure at the three locations. However, at the most stress-prone location, within-population variability is relatively high due to recombination, whereas the population selected at the most fertile location is highly dominated by one genotype. Across all locations, the genetic variation within this cultivar was maintained. The other two cultivars exhibited a very low genetic variability and were maintained at all three farms without changing their characteristic seed weight significantly.

A general yield improvement by selection for larger seeds was observed in all cultivars. The full genetic variation within one cultivar was maintained by the selection for both extremes in seed size. Selection within two cultivars with very low genetic variability resulted in an unintended genetic modification from 
the initial material by selecting 'off-types', probably resulting from spontaneous outcrossing, with smaller seeds in one case and with larger seeds in the other.

Significant site-specific variation in drought tolerance was not found. Thus, the effect of year may have counteracted a continuous site-specific adaptation or selection sites are not as distinctly different as expected in water regimes. Consequently, the main factors involved in the continuous site-specific changes in one cultivar remain unidentified. It was observed that cultivars reacted differently to drought conditions.

On-farm management with lentil can lead to a site-specific development and site-specific adaptation may occur in the long-term. Given a substantial genetic variability, seed yield, straw yield, harvest index, seed weight, and flowering time were altered significantly by natural selection.

Our results prove the maintenance and management on-farm of plant genetic resources in an autogamous species a dynamic management strategy. For the maintenance of material with substantial genetic diversity, at least two farms with significantly different environmental conditions are necessary. Homogeneous accessions, when combined with ex situ maintenance, could be managed at one location. I recommend the characterization of the material in advance for its genetic diversity and outcrossing potential to establish a well-grounded management strategy accordingly. Different material of the same crop should not be maintained at one farm. Selection for traits considered negative for agronomic performance and monitoring of characteristic traits may be considered to preserve the integrity of the material and/or to improve its agronomic performance. To study the main factors involved in site-specific adaptation by natural selection for autogamous crops, I suggest using genetically broad populations, which should be well characterized in advance, phenotypically as well as by molecular markers, to monitor their spatial and temporal development in diverse environments. 


\section{APPENDIX}
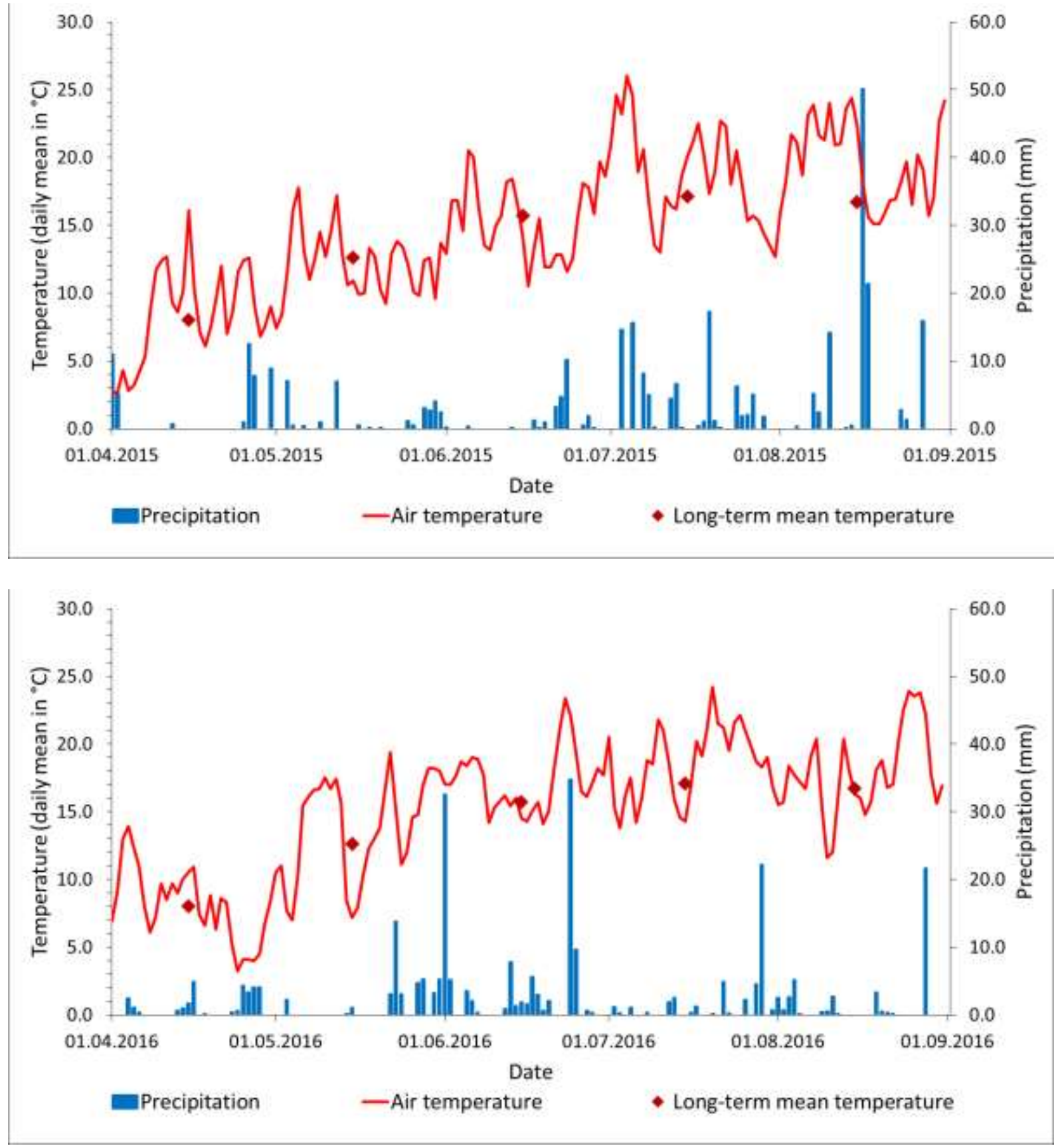

FIGURE A1 Temperature and precipitation at Reinshof, April - August 2015 (upper) and 2016 (lower).

Data source: Meteorological station Göttingen (long-term mean temperature 1981-2010), Deutscher Wetterdienst (www.dwd.de/WESTE) 

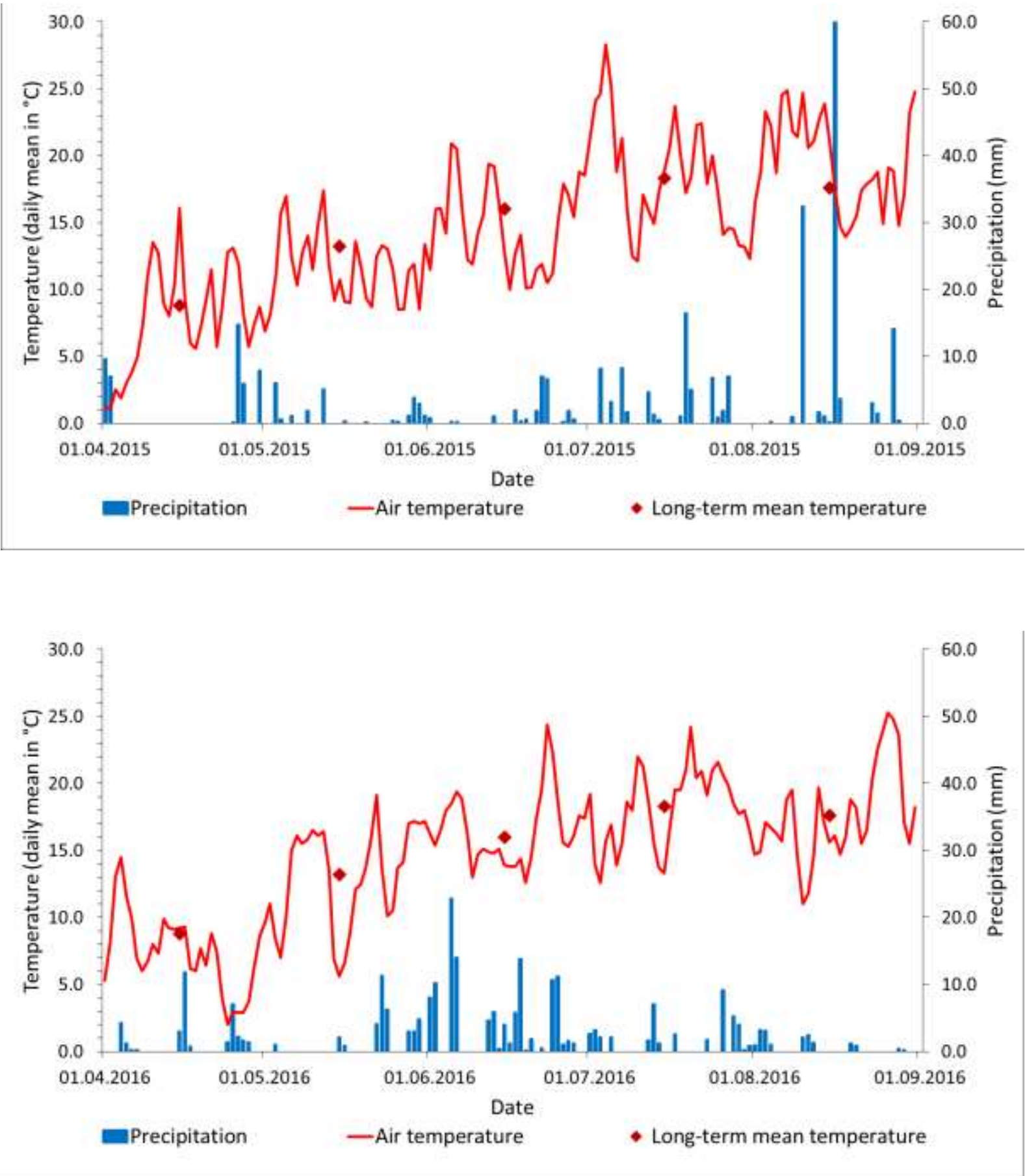

FIGURE A2 Temperature and precipitation at Schönhagen, April - August 2015 (upper) and 2016 (lower).

Data source: Meteorological stations Leinefelde (temperature), Bad Sooden-Allendorf (precipitation), and Eschwege (long-term temperature mean 1981-2010), Deutscher Wetterdienst 

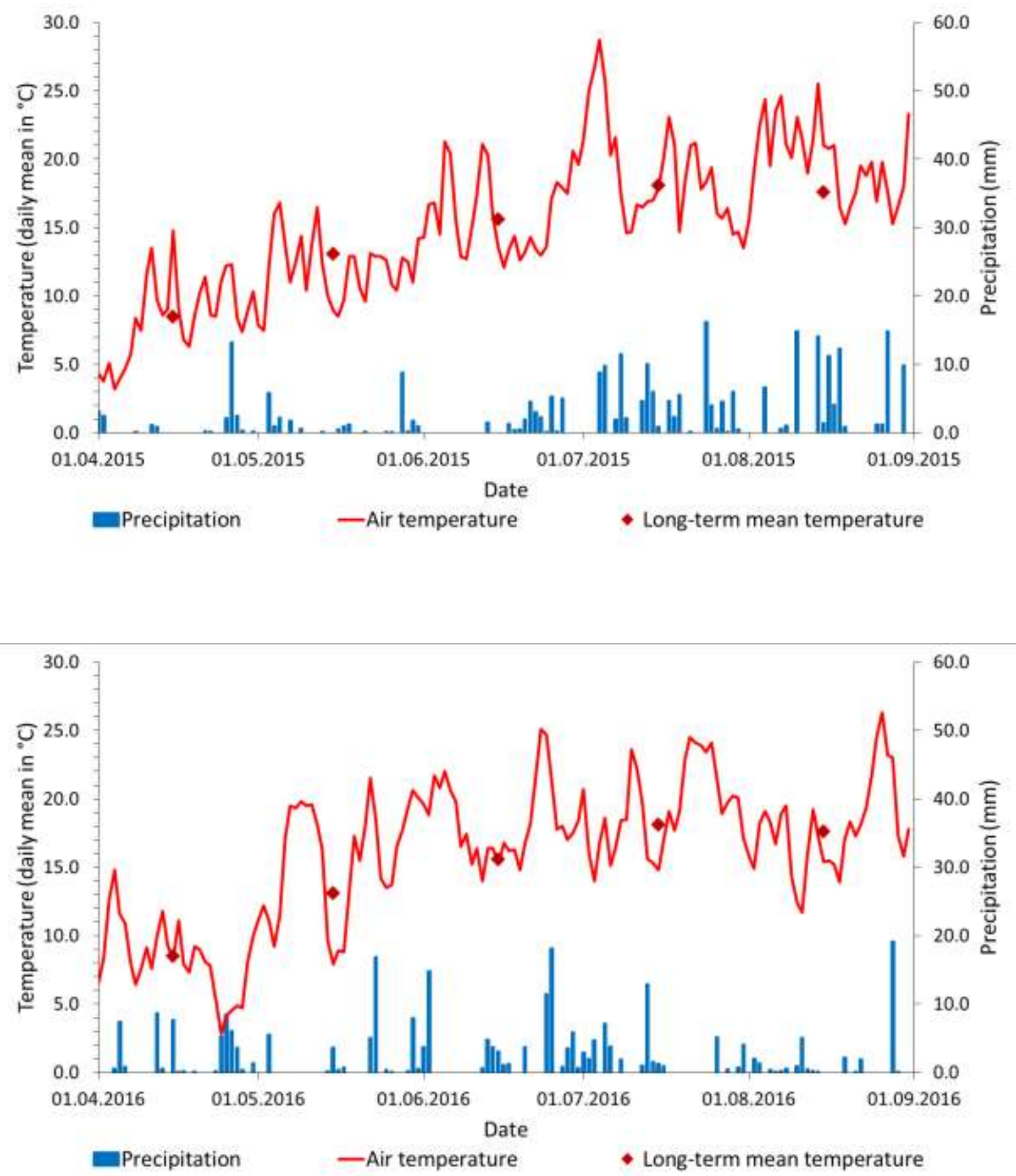

FIGURE A3 Temperature and precipitation at Darzau, April - August 2015 (upper) and 2016 (lower).

Data source: Meteorological stations Lenzen/Elbe (temperature), Bleckede-Walmsburg (precipitation), and Wendisch-Evern (long-term temperature mean 1981-2010), Deutscher Wetterdienst

(www.dwd.de/WESTE) 


\section{DANKSAGUNG (ACKNOWLEDGEMENTS)}

Einen herzlichen Dank möchte ich Heiko C. Becker aussprechen für die Überlassung des Themas, die Betreuung und insbesondere die ermunternden, schlichtenden, beruhigenden und motivierenden Worte zur richtigen Zeit sowie die hilfreichen Diskussionen.

Bernd Horneburg danke ich für die intensive praktische Betreuung innerhalb seiner Fachgruppe und die Vermittlung seiner langjährigen Erfahrungen mit den Linsen.

Gunter Backes danke ich für die Übernahme des Koreferats. Klaus Dittert sei gedankt für die Einwilligung als drittes Mitglied im Prüfungskomitee bei der Disputation aufzutreten. Außerdem danke ich ihm für die Hilfe bei der Diskussion der Trockenstress-Ergebnisse. Mehmet Senbayram danke ich für die Beratung zum Trockenstressversuch sowie die regelmäßige Überlassung der Thermobild-Kamera. Wolfgang Link sei gedankt für Beratungen zum Felddesign und zur statistischen Auswertung.

Der DFG und der Software AG Stiftung danke ich für die Finanzierung des Projektes bzw. der Fachgruppe insgesamt.

Einige StudentInnen waren als Hilfskräfte ausgesprochen wichtig und haben den teilweise sehr aufwendigen und arbeitsintensiven Versuchen mit zum Erfolg verholfen. Stellvertretend für alle diese helfenden Hände nenne ich diejenigen namentlich, die auch eine Abschlussarbeit in diesem Projekt verfasst haben und somit auch inhaltlich wesentlich zum Thema meiner Arbeit beigetragen haben. In der chronologischen Reihenfolge nach Abgabe ihrer schriftlichen Arbeiten sind dies: Salim Trouchaud (B.Sc.), Moritz Halekotte (B.Sc.), Thorben Becher (M.Sc.), Male Bockelmann (M.Sc.) und Yingying Zhong (M.Sc).

Auch die technischen Arbeitskräfte waren in diesem Projekt stark gefordert. Somit danke ich sehr, sehr herzlich Barbara Wedemeyer-Kremer, die als technische Assistentin organisatorisch und praktisch im Feld viel geleistet hat und damit dieses Projekt ermöglichte. Zusätzlich war sie in manchen schwierigen Situationen eine mentale Stütze. Auch Ulrike Hill hat sich zeitweise sehr intensiv mit den Linsen im Feld und Gewächshaus sowie zur Aussaatvorbereitung und zur Nachernteaufbereitung beschäftigt. Vielen Dank dafür. Für die Koordination aller technischen Kräfte im Feld danke ich Dirk Hunold. Frank Gemmeke danke ich für die intensive Auseinandersetzung mit allen Problemen des Trockenhäuserauf- und Abbaus sowie für die verantwortungsvolle Übernahme der Auf- und Abbauleitung dieser ,mobilen` Häuser.

Für die zur Verfügung gestellten Flächen und die Nutzung mancher Infrastruktur an den Außenstandorten danke ich Karin Weng in Schönhagen sowie Ernst-Heinrich Schmidt vom Hof Darzau und Karl-Josef Müller von der Getreidezüchtung Darzau. Für die Betreuung und Pflege des Versuches in Darzau danke ich Lothar Ulrich (Sommer 2015) und Mark Fellechner (Sommer 2016) sehr herzlich.

Meinen MitdoktorandInnen und KollegInnen danke ich für die schöne Zeit und Unterstützung, für die schönen gemeinsamen Mensa-Mittagspausen, die tollen Exkursionen und manche abendlichen Amüsements. Danke Antje für die Durchhalte-Leckerlies während der Schreibphase und danke Mareile, dass ich nicht immer alleine meine Kopflüftungs-Gänge um das Klinikum machen musste.

Gitanjali More danke ich für Verbesserungen meiner Englischgrammatik und Ausdrucksweise.

Meiner Familie und meinen Freunden danke ich für Geduld und Rücksicht. Meiner geliebten K1-WG danke ich für das angenehme Wohn- und Lebensumfeld und das Aushalten einigen Geredes über Linsen.

Meiner Freundin Sari danke ich für ihre besonders große Geduld, die unvergesslichen Urlaube und für manche nötige und hilfreiche Ablenkung. 


\section{Curriculum Vitae}

\begin{tabular}{|c|c|c|}
\hline Name: & \multicolumn{2}{|c|}{ Ruland } \\
\hline Surname: & \multicolumn{2}{|c|}{ Michael } \\
\hline Birth: & \multicolumn{2}{|c|}{ 01. Sept. 1986, in Filderstadt } \\
\hline Nationality: & \multicolumn{2}{|c|}{ German } \\
\hline Contact: & \multicolumn{2}{|r|}{ Email michael.ruland@gmx.net } \\
\hline Address: & \multicolumn{2}{|r|}{ Georg-August-Universität, DNPW, Von-Siebold-Str. 8, 37083 Göttingen, Germany } \\
\hline \multicolumn{3}{|l|}{ Education } \\
\hline \multirow{3}{*}{\multicolumn{2}{|c|}{ Mar 2014 - May 2017}} & PhD student in plant breeding \\
\hline & & Georg-August-Universität Göttingen, Germany \\
\hline & & Department of Crop Science, Division of Plant Breeding \\
\hline \multirow{3}{*}{\multicolumn{2}{|c|}{ Oct $2011-$ Nov 2013}} & Master of Crop Sciences \\
\hline & & Universität Hohenheim, Germany \\
\hline & & Major: Plant Breeding and Seed Science \\
\hline \multirow{3}{*}{\multicolumn{2}{|c|}{ Oct $2007-\operatorname{Jan} 2011$}} & Bachelor of Environmental Sciences \\
\hline & & Carl-von-Ossietzky-Universität Oldenburg, Germany \\
\hline & & Major: Landscape Ecology and Landscape Planning \\
\hline Jun 2006 & & Abitur (High School Diploma) \\
\hline \multicolumn{3}{|l|}{ Work experience } \\
\hline \multicolumn{2}{|c|}{ Jan 2018 - present } & Breeder / \\
\hline \multicolumn{2}{|c|}{ Jun - Dec 2017} & Selector at Rijk Zwaan in Marne, Germany, for cabbage (Brassica oleracea) \\
\hline \multicolumn{2}{|c|}{ Mar 2014 - May 2017} & Scientific staff at Georg-August-Universität Göttingen, Germany \\
\hline
\end{tabular}

Internships and part-time jobs

Feb - Aug 2013 and

Oct 2011 - Jun 2012

Jul - Aug 2012

Feb - Aug 2011

May-Sep 2010

Oct $2009-$ Feb 2010

Jul - Oct 2009

Sep 2006 - Sep 2007
Student assistant in the worldwide breeding program of Jatropha curcas at JatroSelect GmbH in Stuttgart, Germany Internship in plant breeding for organic farming at Research and Breeding, Dottenfelder Hof, Bad Vilbel, Germany Internship in Jatropha curcas breeding at JatroSelect $\mathrm{GmbH}$ in Cameroon, Africa Assistant of the breeding manager for three locations Student assistant in the Jadebay-Project at University of Oldenburg, Institute for Chemistry and Biology of the Marine Environment (ICBM) Student teaching assistant at University of Oldenburg, Institute for Biology and Environmental Sciences (IBU) Internship in landscape conservation planning at LUP Kohl (Agency for Landscape Architecture and Environmental Planning) in Göttingen, Germany Gap year taken to do voluntary work in the environmental sector (FÖJ) in environmental education at Regional Centre for Environmental Education (RUZ) Huntlosen-Hosüne, Germany 